Portland State University

PDXScholar

$4-7-2020$

\title{
Re-engaging Individual Capacities in Service of Civic Capacity: a Model of Holistic Civic Engagement Education for the University
}

Jane Gerald Carr

Portland State University

Follow this and additional works at: https://pdxscholar.library.pdx.edu/open_access_etds

Part of the Civic and Community Engagement Commons, Higher Education Commons, and the Public Administration Commons

Let us know how access to this document benefits you.

\section{Recommended Citation}

Carr, Jane Gerald, "Re-engaging Individual Capacities in Service of Civic Capacity: a Model of Holistic Civic Engagement Education for the University" (2020). Dissertations and Theses. Paper 5453.

https://doi.org/10.15760/etd.7326

This Dissertation is brought to you for free and open access. It has been accepted for inclusion in Dissertations and Theses by an authorized administrator of PDXScholar. Please contact us if we can make this document more accessible: pdxscholar@pdx.edu. 
Re-engaging Individual Capacities in Service of Civic Capacity:

A Model of Holistic Civic Engagement Education for the University

by

Jane Gerald Carr

A dissertation submitted in partial fulfillment of the requirements for the degree of

\author{
Doctor of Philosophy \\ in \\ Public Affairs and Policy
}
Dissertation Committee:
Jennifer Allen, Chair
Heather Burns
David Hall
Billie Sandberg

Portland State University

2020 
(C) 2020 Jane Gerald Carr 


\begin{abstract}
A healthy democracy requires active civic engagement. Effective civic involvement can be encouraged by education that helps students learn to respect diverging viewpoints and build skills such as critical thinking about policy frameworks. In higher education, we have seen progress in teaching for civic engagement despite pressures to focus narrowly on career preparation. However, it is important to build on this work in two ways. First, the noncognitive and holistic dimensions of civic engagement have not been thoroughly considered in designing civic education. Second, the field could reach its goals more effectively by adopting teaching strategies that directly help students ameliorate and resolve what hinders their engagement.
\end{abstract}

This study contributes to these two areas by presenting a new model that accounts for the holistic nature of civic engagement and a curricular tool to help students transform the assumptions and mindsets that undermine their attempts to engage. The Model of Holistic Civic Engagement Education and re-engagement tool were developed out of a synthesis of literature from an array of disciplines including Indigenous knowledge. This dissertation presents the findings from an action research study in which the Model and tool were implemented in two undergraduate courses. Findings suggest that the reengagement tool, applied through specific narrative essay assignments, holds promise as a means for increasing civic engagement capacity. Findings also suggest that the Model can be a useful approach for course design, and that further study should be undertaken to reveal more about its applicability to educational and civic settings. 


\section{Acknowledgements}

I am very grateful for the many people who have supported me throughout my doctoral studies and in writing this dissertation. First among these is my committee chair, Jennifer Allen, whose intelligent, strategic, optimistic, and open-minded guidance has been essential throughout.

My three committee members have contributed significantly to this project and to my doctoral education. Heather Burns demonstrated to me what care and community can look like in higher education, and consequently helped give me the courage to pursue my true interests in this thesis. Bille Sandberg has taught me something I came to the academy to learn--how to make a claim without insisting on my views nor diminishing their value. David Hall has shown me with his generous support how to make an ally out of skepticism in order to bring ever more integrity and care to my writing and teaching.

I am also grateful to the other Portland State University faculty who have mentored me throughout my program: Judith Ramaley, Lindsay Desrochers, Sherril Gelmon, Sybil Kelly, and Kevin Kecskes.

My parents Patricia Bourne and Gregg Carr have supported me with the utmost care though this and all other phases of my education, and have never blinked at my extensive requests for their invaluable editorial input. My gifted colleagues in the Civic Leadership Minor, Erin Elliott, Jennifer Joyalle, and Phyusin Myint have shown me the profound value of allyship and collaboration. My friends and colleagues Rebecca Hyman, Katharine Sprecher, Beth Duckles, Jessica Outlaw, Kate O’Kelley, Langston Kahn, 
Audrey LaRue, Leslie Fleming, Betty Shelley, and Angela Hamilton have gifted me time and again with rare insight, care, and solidarity.

Finally, I am grateful to Christina Pratt and the work she does through the Last Mask Center. This work has deeply shaped me and my dissertation. The community of people connected to the Last Mask Center have showed me time and again what it can mean to move through doubt in order to act upon vision. 


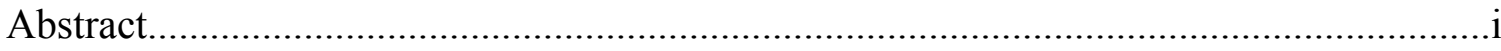

Acknowledgements..............................................................................................

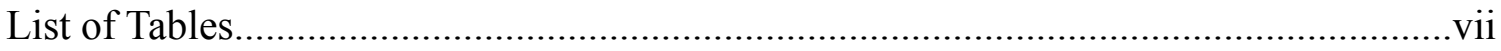

List of Figures........................................................................................................

Chapter One: Introduction......................................................................................................1

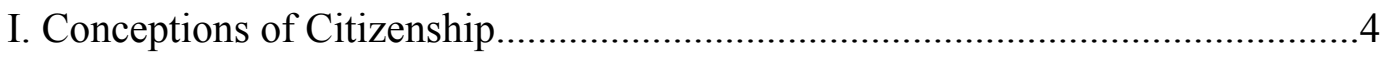

Civic republicanism.............................................................................

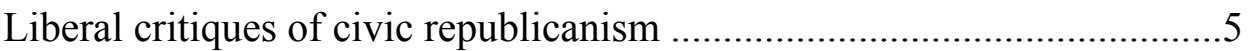

Critical conceptions of citizenship ..........................................................

II. Civic Engagement Education........................................................................9

The civic role of universities ...................................................................10

Teaching for civic republicanism in the university .................................13

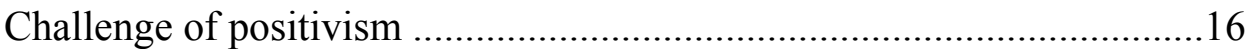

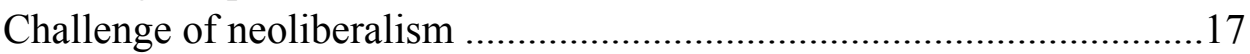

Furthering civic republican and critical citizenship education .................19

III. Holism as a frame for Civic Engagement Education........................................21

IV. Conclusion: Toward a model of holistic civic engagement education in the

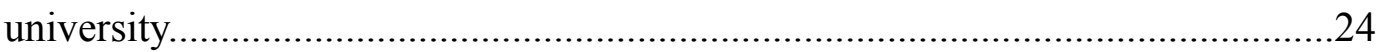

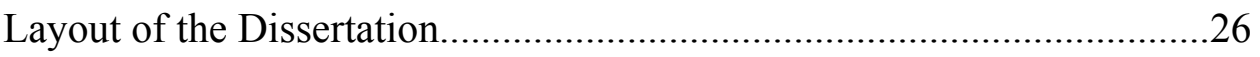

\section{Chapter Two: Literature Review and Model of Holistic Civic Engagement}

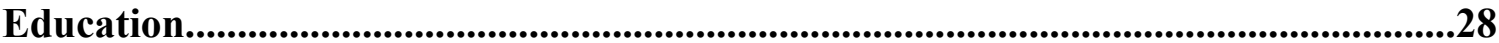

I. Perspectives on Civic Engagement Education.....................................................28

Two-part holism: Cognitive and behavioral................................................30

Three-part implicit holism: Cognitive, behavioral and implicit

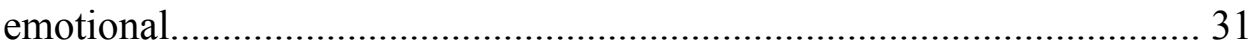

Three-part holism: Cognitive, behavioral, and explicit emotional..............36

Four-part holism: Cognitive, behavioral, emotional and spiritual .............43

Conclusion: Toward a map of holistic civic engagement education...........60

II.Modeling and Implementing Holistic Civic Engagement Education..................66

Model of Holistic Civic Engagement Education......................................69

Teaching from the Model: Re-engagement Tool.........................................76

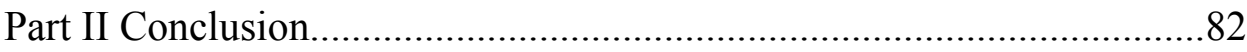

Chapter Three: Study Design........................................................................................................84

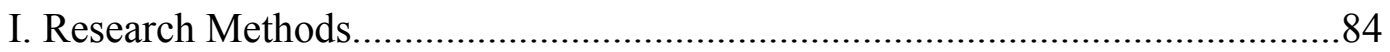




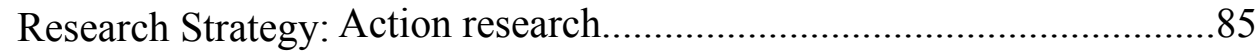

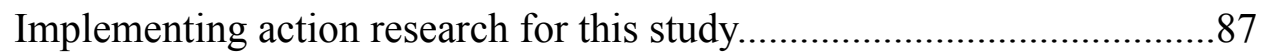

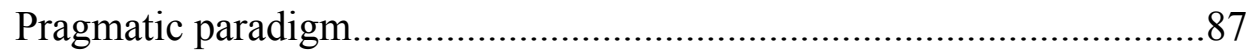

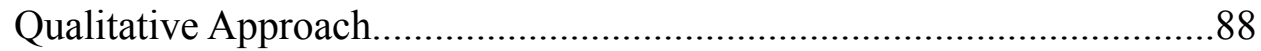

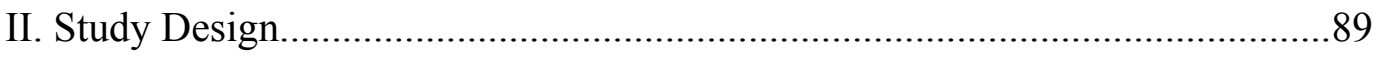

Course One: Introduction to Civic Engagement.......................................91

Course Two: Fundamentals of Public Service.............................................92

Applying the Model and Re-engagement Tool to the Study Courses........93

Research Participants............................................................................101

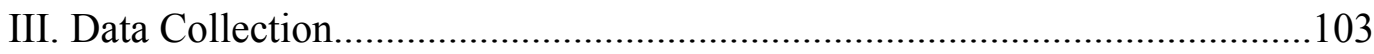

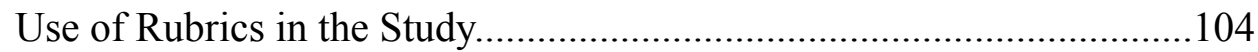

Approval, Consent, and Protection of Human Subjects...........................104

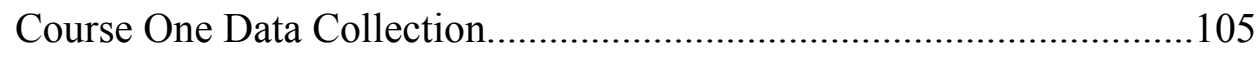

Summary of Course One Data Collection...............................................114

Course Two Data Collection..................................................................115

Summary of Course Two Data Collection...............................................121

Additional Data Collection: Instructor-Generated Data...........................123

IV. Data Analysis.....................................................................................123

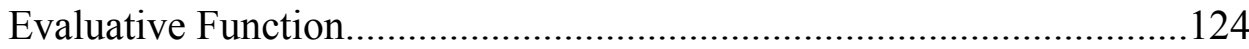

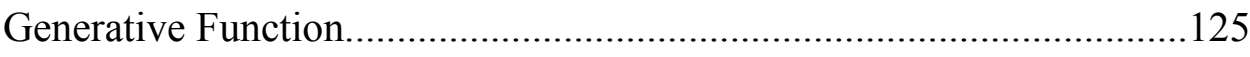

Grounded Theory and Coding Process...................................................125

Research observations and reflections...................................................127

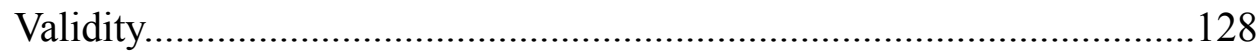

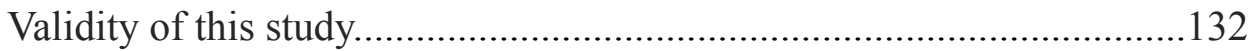

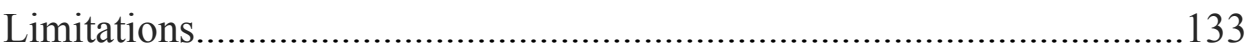

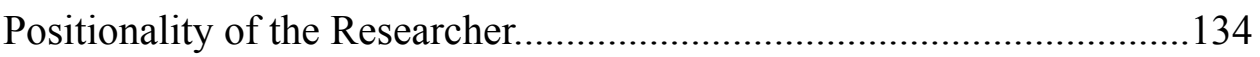

Chapter Four: Results.......................................................................................................138

Course One: Introduction to Civic Engagement................................................139

Pre-Assessment: What is Civic Engagement?........................................140

Narrative Part One: Dis/Engagement Baseline Narrative..........................147

Narrative Part Two: Contextualization of Disengagement.......................161

Narrative Part Three: Civic Vision Narrative..........................................176

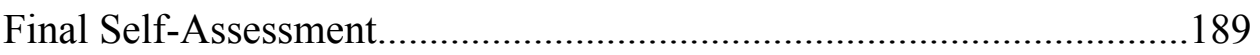

Reflection on Class Community...........................................................197

Course Two: Fundamentals of Public Service...................................................198

Pre-Assessment: What is Public Service?.................................................198

Narrative Part One: What is Service Really?..........................................202

Narrative Part Two: What Allows You to Serve?.....................................208

Weekly Discussion Posts: Deepening Understandings of Service............218

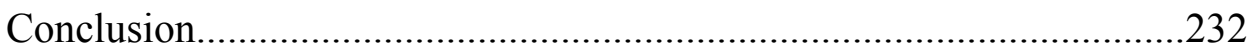




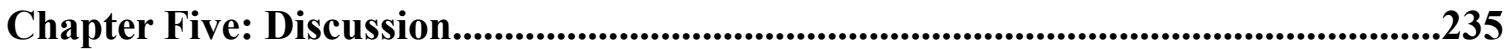

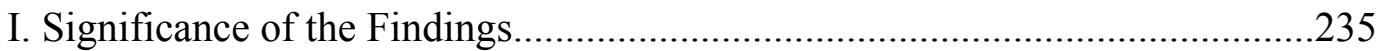

Demonstration of the Holistic Civic Engagement Education (HCEE)

Competencies and Capacities...................................................................235

Impact of the Core Narrative Sequence...................................................239

Areas for Development........................................................................244

Two Key Limitations: Understanding the Curricular Context for

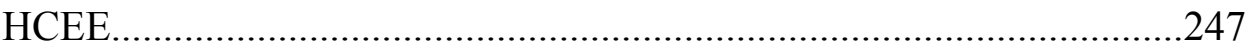

Additional Learnings from Implementation..............................................251

II. Development of the Model of Holistic Civic Engagement Education..............255

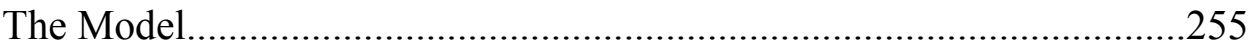

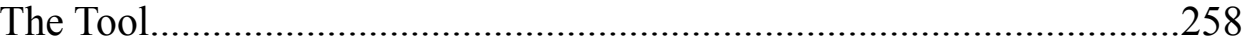

Civic Engagement and the Medicine Wheel..............................................204

III. Broader Implications of HCEE................................................................260

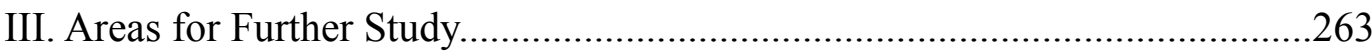

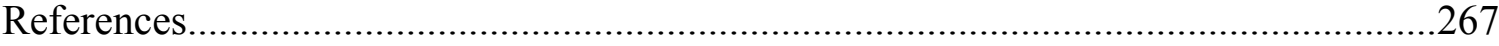

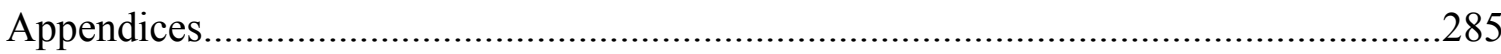

A. Course One Syllabus..................................................................................285

B. Course One Narrative Part One Assignment Description................................297

C. Course One Narrative Part Two Assignment Description.................................299

D. Course One Narrative Part Three Assignment Description..............................301

E. Course One Community Based Learning Final Assignment Description........303

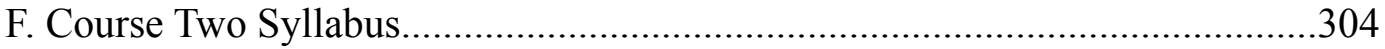

G. Course Two Narrative Part One Assignment Description................................316

H. Course Two Narrative Part Two Assignment Description..................................318

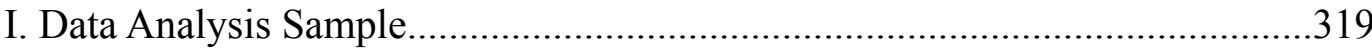

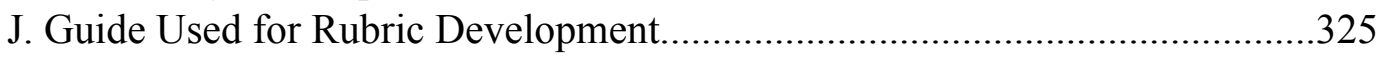




\section{List of Tables}

Table 1.1: Traditional and Civic Republican/ Constructivist Approaches to Citizenship

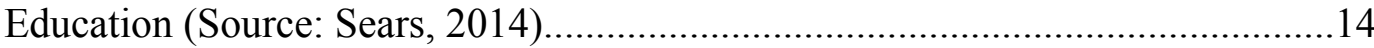

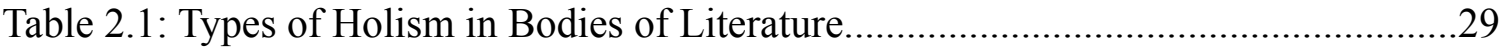

Table 2.2: Synthesis of Literature to Inform Model and Curriculum Design...................61

Table 2.3: Development of the Competencies from Relevant Literature.........................69

Table 3.1: Study Population for Course One.............................................................102

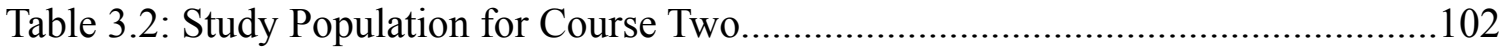

Table 3.3: Assessment Rubric for Course One Narrative Part One.................................109

Table 3.4: Assessment Rubric for Course One Narrative Part Two.................................110

Table 3.5: Assessment Rubric for Course One Narrative Part Three...............................112

Table 3.6: Course One Learning Outcomes and Data Collection Strategies by Primary

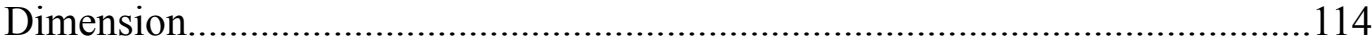

Table 3.7: Rubric for Course Two Narrative Part One.....................................................117

Table 3.8: Rubric for Course Two Narrative Part Two..................................................118

Table 3.9: Rubric for Course Two Weekly Reading Responses...................................121

Table 3.10: Summary of Course Two Learning Outcomes and Data Collection Strategies by Primary Dimension................................................................................. 122

Table 4.1: Categories of Leadership Qualities Mentioned by Students.........................181

Table 4.2: Themes Identified from "What did you value learning?".............................190

Table 4.3: Themes Identified from Students' Civic Engagement Goals...........................192

Table 4.4: Words to Describe this Class as a Community.............................................197

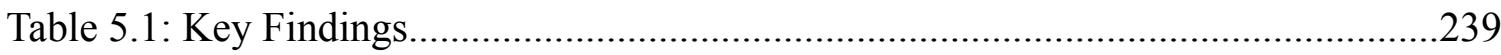

Table 5.2: Summary of Findings Suggesting Areas for Development...........................244

Table 5.3: Example Applications of the Model to Humanities/Social Science

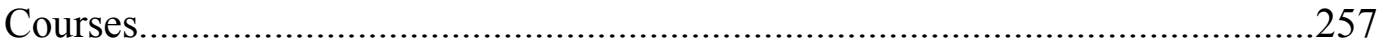

Table 5.4: Simplified Re-engagement Tool..........................................................258 


\section{List of Figures}

Figure 2.1: The Medicine Wheel and Stages of Learning (Source: Bell, 2014)...............55

Figure 2.2: Holistic Dimensions and Learning Stages (Source: Bell, 2014)....................56

Figure 2.3: Gifts of the Four Directions (Source: Bell, 2014).....................................68

Figure 2.4: Model of Holistic Civic Engagement Education around Bell's Wheel...........68

Figure 2.5: Re-engagement Tool for Holistic Civic Engagement Education...................78

Figure 5.1: Model of Holistic Civic Engagement Education around Bell's Wheel.........256

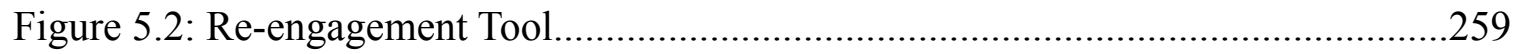




\section{Chapter One: Introduction}

Civic engagement is vital to the functioning of democracy, and has a key role to play in helping to meet the democratic governance challenges underlying important issues such as climate change, political polarization, and economic inequality (Flanagan \& Levine, 2010; Hart et al., 2014). Civic engagement - the political and civil society participation of citizens - has historically been central to American democratic governance. The mode of citizenship longest associated with American democracy is “civic republicanism," which emphasizes active deliberation, through "association," and shared concern for the common good, or "virtue" (Sandel, 1996; Sears, 2014). Civic republican participation requires a multi-faceted skill set comprised of critical thought and analysis, but also of care, relating to others, and sacrifice of personal gain for the common good (Ehrlich, 2008; Saltmarsh, 2011). In this way, true civic republican participation occurs at multiple levels of human functioning - it blurs the line between thought and feeling, and embodies a capacity for analytic thinking that is informed by care, and a capacity for care informed by clear discernment.

The key context for use of the multi-faceted skill set of civic republican participation is within associations. In associating, citizens ${ }^{1}$ exchange ideas and arrive at well-considered political decisions. It is their openness to one another, and to an array of perspectives, that furthers the aim of wise action. Thus, three components - relating,

\footnotetext{
${ }^{1}$ Here I use the terms "citizen" and "citizenship" according to their broad conceptions, rather than referring to legal status. This dissertation deals with questions of engagement and participation in community that are relevant regardless of individuals" legal status. As Turner (1993) argues, citizenship can be seen as "a set of social practices which define the nature of social membership" (p. 4). We therefore employ a broad conception of citizenship that refers to the practices of participation in democratic community (See also Denhardt \& Denhardt, 2015, pp. 25-30).
} 
analysis, and care-are intermingled and interdependent in the full expression of citizenship. As Tocqueville wrote in his classic early nineteenth century study of American democracy, "The only way opinions and ideas can be renewed, hearts enlarged, and human minds developed is through the reciprocal influence of men upon each other" (1805-1859/2003, p. 598). Contemporary scholars in the civic republican tradition have adopted this perspective about civic engagement, with canonical contributions focusing upon concepts such as "better together" and the "habits of the heart," and even upon "the structure of belonging" and "healing the heart of democracy" (Bellah, et. al, 2007; Block, 2008; Palmer \& Zajonc, 2010; Putnam \& Feldstein, 2004).

Education that prepares people for democratic citizenship is of significant concern to some contemporary scholars (Ehrlich, 2008; Flores \& Rogers, 2019; Jacoby, 1996, 2009; Saltmarsh, 2011; Saltmarsh, Hartley \& Clayton, 2009). Education, especially higher education, is seen by many as an essential tool for strengthening democratic function and enabling effective responses to environmental and social problems (Sears, 2014). Many scholars adopt the civic republican perspective and seek to instill this ethic and skill set in students. Others, however, are influenced by alternative perspectives. One of these is liberalism—-both the liberal critique that individual rights trump communal orientation, and the neoliberal emphasis on market freedom as a proxy for the common good (Mirra \& Morrell, 2011; Sandel, 1996; Stone, 1997). A second factor shaping how civic republicanism can be taught is the traditional culture of formal educational institutions in the United States (Bok, 2003). Typically, educational institutions have tended to emphasize positivist epistemologies (Zlotkowski, 2011). An emphasis on the 
verifiable and quantifiable is important in education to teach logical and evidence-based thought processes. However, some argue that it should include exploration of multiple ways of knowing, and that democratic citizenship can be better taught if other epistemologies are embraced (Palmer \& Zajonc, 2010; Zlotkowski, 2011).

Despite the philosophical and institutional culture challenges, there is a scholarly consensus that it is important to develop pedagogies that instill civic republican values (Peterson, 2011; Sears, 2014). Rather than reflecting a specific partisan orientation, civic republicanism embodies the belief that citizens are capable of deliberation, of making meaning out of complex political realities, and acting generously. I will argue that it is worthwhile to focus on teaching the full skill set of civic republicanism, and to consider how relating, analyzing, and caring can be best taught in the current context. This inquiry has been under-explored in academic study, though interest is growing in understanding the noncognitive factors in political behavior (e.g. Holbein \& Hillygus, 2020). ${ }^{2}$ This dissertation enters this field of inquiry by framing civic engagement as an inherently multi-faceted endeavor, seeing education for civic engagement through that lens, and developing an approach to map and teach this holistic conception of civic engagement in one important educational context, the college classroom. Creating this map requires us to first consider which conceptions of citizenship and civic engagement we will adopt, as this conception shapes the aims and approaches of civic education.

\footnotetext{
${ }^{2}$ Holbein \& Hilligus (2020) found that low turnout among young voters-including those who said they intended to vote - was not the result of apathy. Rather, the ability to follow through on political intentions like voting was enabled by noncognitive factors such as a capacity for self-regulation.
} 


\section{Conceptions of citizenship}

\section{Civic republicanism}

Civic republicanism, though not universally embraced in academe or in public life, is generally considered by scholars to be a foundational approach to understanding civic engagement (Barber, 2003; Putnam, 1994; Sandel, 1996; Sears, 2014). Historically, civic republicanism was a dominant philosophy in the eighteenth and nineteenth centuries (Sandel, 1996). Civic republicanism "embodies an active conception of what it means to be a citizen," including a "broad commitment to civic obligations, the common good, civic virtue, and deliberative civic engagement" (Peterson, 2011, p. 7). According to this conception, citizenship is a "practice," a responsibility but also a means for growth and development (Peterson, 2011). Tocqueville (1805-1859/2003) wrote that the qualities of self-sacrifice and virtue were beneficial for society, but also built character in individuals. "Sacrifices" he wrote, "are as necessary to the man [sic] who makes them as to those gaining from them" (p. 610). The enemy of this kind of virtue was individualism, the "calm and considered feeling which persuades each citizen to cut himself off from his fellows" (1805-1859/2003, p. 587).

In the civic republican strand of thought, individual and community wellbeing are deeply intertwined; self-interest is to be "properly understood" as the benefit an individual receives through embracing the responsibility to care for the common good (Tocqueville, 1805-1859/2003). Sandel (1996) explains this further, writing that "even the liberty to pursue our own ends depends on preserving the freedom of our political community, which depends in turn on the willingness to put the common good above our 
private interests" (p. 26). Self-interest, therefore, cannot be conceived of merely as individual preference, but must be seen in terms of how community-wide benefits serve all members.

Civic republicanism has modern as well as historical proponents. Barber (2003), for example, argues for the applicability of Tocqueville's frame, adding to it by pointing out the importance, for instance, of virtues such as humility: "After all," he writes, "the recognition that I might be wrong and my opponent right is at the very heart of the democratic faith" (p. 138). Embedded in the civic republican conception are important values and world views - the assumption that individual and collective wellbeing are inextricably tied, and that when citizens act out of service and sacrifice of self-interest, they can create a better society than one forged from an amalgam of individual preferences.

\section{Liberal critiques of civic republicanism}

Civic republicanism, though typically embraced by civic engagement scholars, has been largely replaced by liberalism as a dominant American political ideology (Sandel, 1996; Sears, 2014). Liberalism stems from critiques of republicanism's attempts to place the common good above individual self-interest. For instance, Rawls argued that "The rights secured by justice are not subject to political bargaining or to the calculus of social interests" (1971, p. 25). Liberal philosophy emerged partly from twentieth century concerns that an increasingly plural United States could no longer hope to arrive at shared conceptions of the common good (Sandel, 1996). 
Liberal democratic governance is concerned with individual rights and just procedures - it seeks to carve out personal freedom from societal forces, rather than forge freedom to self-govern. American liberalism drew from thinkers such as Hobbes, Locke and Mill. Hobbes, the seventeenth century originator of what has come to be known as "social contract theory," argued for conceiving of the government-citizen relationship as a contract between equals. This framed citizens' power primarily in terms of their legal rights as individuals. Similarly, Locke, also writing in seventeenth century England and in response to authoritarianism, argued that sovereignty resided in the citizenry. $\mathrm{He}$ believed individuals had the capacity to exercise reason and that natural law granted them freedom from tyrannical government. Finally, J.S. Mill, two hundred years later, developed liberal philosophy further with his arguments for the sanctity of individual rights. He argued that nothing, except self-protection, could warrant infringement upon an individual's rights. These ideas were indeed foundational in the establishment of American democracy and can be seen in the Bill of Rights, in particular.

While civic republicanism was also a strong influence in the eighteenth and nineteenth centuries, the twentieth century saw the ascendency of liberalism as the dominant political ideology (Sandel, 1996). Liberalism asserted that the deliberation required by republican self-government had been outdated by the now-plural nation's varying definitions of morality, and thus a conception of freedom as comprised of protections and rights, was necessary. Government should concern itself with assuring that just procedures were in place to protect rights. Contemporary philosopher Sandel (1996) critiques this approach, arguing that "The procedural republic cannot secure the 
liberty it promises, because it cannot sustain the kind of political community and civic engagement that liberty requires" (p. 24). Sandel argues that this shortcoming is worsened by liberalism's view of citizens as passive recipients of rights and the objects of treatment, and thus it fuels disempowerment and loss of agency.

It is important to consider the critiques of liberalism without losing sight of the promise of republicanism. Liberalism claims that individual rights must be secured against a potentially impinging government, and that moral and religious beliefs are not to be prescribed or enforced by government. The civic republican response to this is that government can still honor personal liberties, while also encouraging civic discourse that can reveal shared notions of the common good.

\section{Critical conceptions of citizenship}

Closely related to civic republicanism is the contemporary framework of a market versus polis conception of citizenship developed by Stone (1997) in Policy Paradox. Stone (1997) notes that a market-based conception of citizenship sees individuals as rational and self-interested, competing for scarce resources in the marketplace. The common good is conceived of as individuals having achieved what they personally desire, often through enhancement of their ability to compete. In the market conception, justice means giving each individual a fair opportunity to compete, and the good life is achieved through maximization of utility. The polis conception, on the other hand, takes the basic unit of society not as the individual, but as the community. This perspective maintains that the good life involves belonging to a community that collaborates toward shared interests. In this conception, change can occur because of deliberation and sharing 
of ideas, and decisions can be made out of loyalty or identification with group interests. In the polis conception, policy dilemmas revolve around the balance of individual and communal interests.

In addition to Stone, other contemporary scholars have contributed to modern conceptions of citizenship that align with civic republicanism (Banks, 2017). Like Stone, these scholars adopt the premise that neoliberalism, rather than civic republicanism or liberalism, has become the dominant philosophy shaping politics and education currently (Brown, 2015). Neoliberalism can be understood as a "widely and deeply disseminated governing rationality" or a "normative order of reason" that conceives of humans and human endeavor "according to a specific image of the economic" (Brown, 2015, pp. 9-10). Neoliberalism is seen as all-pervasive and transforms our very understanding of citizens from "Homo Politicus" to "Homo Oeconomicus" (Brown, 2015). Mirra and Morrell (2011) argue, in their discussion of critical civic engagement education, that neoliberal philosophy leads to education that emphasizes personally responsible citizenship, individualism and consumerism. They argue that this is the dominant model shaping practice in educational institutions. However, a critical conception of citizenship would require us to instead value collectivism, productive interactionism, and authentic engagement (Mirra and Morrell, 2011). Related to the concept of critical citizenship is that of "transformative citizenship" (Jagers, Rivas-Drake \& Williams, 2019). Banks (2017) argues that this is the conception of citizenship most aligned with critiques of neoliberalism, and explains that it refers to civic action toward human rights, social justice, and equality. 
Critical and transformative conceptions of citizenship reiterate the civic republican emphasis on collective actions. Significantly, they add the criteria that civic engagement serves the expansion of human rights and the goal of equity. Rising inequality is seen by many scholars to result in negative democratic outcomes, such as decreased political voice (Jacobs \& Skocpol, 2005), diminished social trust (Uslander \& Brown, 2005), and reduced capacity to generate effective environmental policies (Stiglitz, 2012). The goals of increased economic equality (Galbraith, 1998) and improved civic participation and empowerment (Christens, Winn \& Duke, 2016) are thus seen to be important goals for democratic governance and civic republican participation.

From the above summary, we see that together, civic republican and critical conceptions of citizenship imply a particular understanding of civic engagement. Civic engagement is seen as collaborative and relational. It is believed to be generative, in that group discourse can yield insights beyond the capacity of individuals. It values justice and critical thinking, and asserts that humans ought to see themselves as empowered actors. It proposes that some surrender of self-interest can yield community benefits that outweigh the costs. In this way, it asks citizens to trust in the democratic process, and in one another's commitment and care. All of this is much to ask in a context of intense political polarization. Nonetheless, the question of how we can move in this direction is well worth exploring.

\section{Civic engagement education}

If we pose the question of how we as a citizenry can move toward embodiment of civic republican and critical citizenship, part of our answer lies in education. American 
schools and universities have long had an explicitly civic role. Recently, there has been a surge in interest in the civic dimensions of education. In particular, much work has been given to establishing the importance, and defining the scope and aims, of civic education in universities (Ehrlich, 2008; Flores \& Rogers, 2019; Jacoby, 1996, 2009; Saltmarsh, 2011; Saltmarsh, Hartley \& Clayton, 2009). While all levels of education are thought to be important in teaching civic skills, the role of the university is seen as important in delivering civic learning embedded in, and alongside, career preparation (Colby, et al., 2003; Cole, 2009; Finley, 2011; Saltmarsh, Hartley \& Clayton, 2009). Universities and colleges train a disproportionate number of people who fill positions of leadership. They also have a unique role in providing intellectual resources to communities. In addition to this field of study which directly explores civic education in universities, numerous disciplines—-for instance, Community Psychology, Social Work and Education—have sought to understand how scholarship and teaching can better serve civic functions. This section briefly presents some historical context for the role of universities in citizen preparation, looks at some current perspectives on higher education's role, and analyzes two key challenges that higher education faces in conveying the ethics and practices of civic republican engagement to students.

\section{The civic role of universities}

American higher education institutions have historically been largely aligned with a civic purpose. As Hartley (2011) notes, the founders of the first colonial colleges sought to prepare literate clergymen, not only to meet a current need, but to "advance learning and perpetuate it to posterity" (p. 27). Though religiously based, these colleges were 
concerned with civic continuity and the preservation of their founders' values (Hartley, 2011). As the nation grew, other colleges followed suit and "A commitment to the republic became a guiding obligation for the American college" (Rudolph, 1962, p. 61). This sentiment continued through the nineteenth century, also during which institutions increasingly emerged to educate women and African Americans (Allen \& Epps, 1991; Cruea, 2005). A major turning point for higher education occurred with the Morrill Act of 1862, which used profits from federal land sales to fund universities (Cole, 2009). Though the Morrill Acts did seek to provide agricultural and industrial education, they did so "without excluding other scientific and classical studies" and "in order to promote the liberal and practical education of the industrial classes in the several pursuits and professions in life" (7 U.S.C. § 304). By 1900, the research university became the dominant context for higher education, public-sector institutions were leaders in educational quality, and denominational colleges went into "absolute decline" (Goldin and Katz, 1999, p. 38). While the last decades of the twentieth century saw major shifts in higher education, with decline in state funding, an increased emphasis on career preparation over liberal arts, and the introduction of for-profit institutions, these changes are, in historical context, quite recent (Bok, 2003; Hartley, 2011).

The early 1980s brought fiscal pressures that spurred many institutions to adopt a market-centered model that emphasized pre-professional programs (Boyer, 1987). Academic learning that held commercial value came to receive more support from some institutions, and there was a reduced value, in some departments, of critical thinking and moral inquiry (Fisher, Metcalfe \& Field, 2016; Giroux, 2002). As a response to these 
shifts, a movement among scholars and educational organizations has developed that questions the preeminence of commercially valuable knowledge, and advocates for the renewal of a civic purpose in higher education (Hartley, 2011; Jacoby, 2009; Manning, 2013; Morton, 2011). Giroux (2002), for example, writes that higher education is "one of the few public spaces left where students can learn the power of questioning authority, recover the ideals of engaged citizenship, reaffirm the importance of the public good, and expand their capacities to make a difference" (p. 450). This larger movement has brought forth a range of approaches, from community service in the 1980s, to integration of service learning and academic study in the 1990s (Saltmarsh, 2011). Upon revelations that service-learning was not significantly increasing political engagement, the focus shifted in the 2000s to build the "engaged campus," and civic engagement became the primary framework (Saltmarsh, 2011). Approaches currently include, for instance, developing community-university partnerships, encouraging community-engaged research, and implementing educational practices that prepare students for citizenship (Jacoby, 2009). These reforms have been embraced by many universities themselves, and are supported by a significant network of advocacy organizations and foundations (Association of American Colleges and Universities, n.d.).

In the context of this current movement, we see a focus on civic engagement in universities that largely aligns with the civic republican and critical citizenship conceptions of citizenship (Saltmarsh, 2011; Sears, 2014). Ehrlich (2009), writing as a Senior Scholar at the Carnegie Foundation, argues that civic engagement education is, most essentially, about developing a collective or communal orientation: 
Civic learning means coming to understand how a community functions, what problems it faces, the richness of its diversity, the need for individual commitments of time and energy to enhance community life, and most of all, the importance of working as a community to resolve community concerns (p. vi). In addition, scholars emphasize other key aspects of the habits of civic republicanismdiscernment, value-centeredness, and participation. Morrill (1982) writes that "Education for democratic citizenship involves human capacities relating to judgment, to choice, and above all, to action" (In Jacoby, 2009, p. 365). It is more than the acquisition of civic knowledge; "it includes the exercise of personal responsibility, active participation, and personal commitment to a set of values" (In Jacoby, 2009, p. 365). Saltmarsh (2011), a key contributor to the field, concurs: along with academic and community-sourced knowledge, and skills of critical thinking and problem solving, students need to learn communication, civic imagination and creativity, collective action, coalition building, organizational analysis, and values of justice, inclusion and participation. These valuesbased and strategic skills should be joined in education by experiences of "wholeness," capacities that build the civic republican citizen's trust in deliberative processes and orientation toward the common good (Kecskes, Nishishiba and Morgan, 2013, p. 302). Teaching for civic republicanism and critical citizenship in the university

We also see scholarship investigating how to align pedagogy with the goals of civic republican participation. Sears (2014) has synthesized much of this work, and explains that civic republicanism is typically aligned with constructivist pedagogies. In this context, constructivism refers to the educational theory that knowledge is constructed 
primarily through experience rather than through direct transmission of content. Sears presents a summary table (Table 1.1) that differentiates how traditional versus civic republican/constructivist approaches conceive of civic education. In this case "Traditional" refers to transmissive pedagogies in which the student is seen as the empty vessel to be filled by the teacher's knowledge. The student is seen to be devoid of intrinsic motivation, and inclined toward delinquency and even depravity, and therefore needing to be molded through an authoritarian approach. Institutions are seen as stable, and thus the onus lies upon citizens to adjust to them. In contrast, the civic republican/ constructivist pedagogy sees learners as intrinsically motivated active builders of knowledge. The learning acquired is seen as contextual, and institutions are seen as changeable when the citizenry determines an adjustment is needed.

Table 1.1: Traditional and Civic Republican/ Constructivist Approaches to Citizenship Education (Source: Sears, 2014)

\begin{tabular}{|l|l|l|}
\hline & \multicolumn{1}{|c|}{ Traditional } & \multicolumn{1}{|c|}{ Civic Republican/Constructivist } \\
\hline $\begin{array}{l}\text { Knowledge/ } \\
\text { understanding }\end{array}$ & Fixed, focused on the right answers & Fluid, focus on diverse perspectives \\
\cline { 2 - 3 } & Universal & Contextual/cultural \\
\hline Students & Tending to depravity & $\begin{array}{l}\text { Tending to positive engagement but } \\
\text { vulnerable }\end{array}$ \\
\cline { 2 - 3 } & Recipients, empty vessels & Active builders of knowledge \\
\cline { 2 - 3 } & Compliant, passive & Agents of change \\
\hline $\begin{array}{l}\text { Teaching and } \\
\text { Learning }\end{array}$ & Authoritarian & Authoritative \\
\cline { 2 - 3 } & Didactive, rote, single perspective & $\begin{array}{l}\text { Attention to prior learning, culture, } \\
\text { multiple perspective, dissonance and } \\
\text { variance in outcome }\end{array}$ \\
\hline $\begin{array}{l}\text { Society and } \\
\text { Institutions }\end{array}$ & Stable & In flux \\
\cline { 2 - 3 } & &
\end{tabular}




\begin{tabular}{|l|l|l|}
\hline \multicolumn{1}{|c|}{ Traditional } & \multicolumn{1}{c|}{ Civic Republican/Constructivist } \\
\hline \multirow{2}{*}{} & $\begin{array}{l}\text { Generally acceptable/right—at } \\
\text { least in traditional forms }\end{array}$ & $\begin{array}{l}\text { Always in need of re-examination and } \\
\text { reformation }\end{array}$ \\
\cline { 2 - 3 } & Students are to accept and fit in & $\begin{array}{l}\text { Students are to understand and } \\
\text { participate in reshaping }\end{array}$ \\
\hline
\end{tabular}

To this synthesis, Sears (2014) adds an important analysis of the impact of "the cognitive revolution"- a significant reframing of how people learn - that began with the work of Piaget and continued with Vygotsky and Bruner. Its impact is seen across much educational scholarship, including that of Gardner and his work on multiple intelligences. As Gardner writes, education must move beyond "the correct answer compromise" in which knowledge is seen as "a ritualistic memorization of meaningless facts and disembodied procedures" (Gardner, 2006, p. 135). Instead, meaningful learning experiences should develop "the capacity to take knowledge, skills, concepts, facts learned in one context, usually in the school context, and use that knowledge in a new context" (Gardner, 2006, p. 134). Pedagogically, civic engagement education should be designed to align with critical and civic republican conceptions of citizenship. To teach dispositions, values, habits of mind, and to expand students' capacity to care and act collectively, will require specifically aligned pedagogies. Before considering in more depth what these pedagogies could look like, it is important to discuss two key challenges that must be faced in order to teach civic republican and critical citizenship in universities. 


\section{Challenge of positivism}

Zlotkowski (2011) and others have argued that the dominant epistemology in academe is positivism. Positivism asserts that knowledge is gained through observation interpreted through reason and logic; it tends to reject knowledge derived from introspection. This group of scholars argue that this epistemology powerfully shapes pedagogy and impacts universities' ability to fill a civic role. Schön (1995) adds that no advance in "delivery mechanisms" based on the current epistemology could allow us to make the changes we seek. Boyte (2000) writes in "The Struggle Against Positivism" that this epistemology still structures research, teaching and institutions even though he thinks that its assumptions are not intellectually viable. It sustains an approach to social knowledge that leads to "experts" studying "objects," people who are "to be “manipulated or remedied" (Boyte, 2000, p. 50). This distancing from "objects" of study does not support the relational qualities of civic participation. Furthermore, Palmer (1997) argues that epistemologies within higher education give rise to a certain quality of life: the way we know influences the way we live, and objective, analytical thinking leads us to "make objects of each other and the world to be manipulated for our own private ends" (In Zlotkowski, 2013, p. 22). Zlotkowski (2013) concurs, that "the corollary to our lack of public academic engagement is a private spiritual malaise” (2013, p. 22). A lack of public engagement also leads to faculty feeling a loss of the idealism and community that drew them to higher education (Zlotkowski, 2013). The alternative, these scholars suggest, is an epistemology of knowledge in action, a valuing of experiential and felt knowledge that could shift the dominant culture of higher education. 


\section{Challenge of neoliberalism}

A second challenge for those seeking to teach civic republican and critical modes of citizenship in higher education is the impact of neoliberal philosophy. A group of scholars and educational leaders has argued that neoliberal shifts, such as increasing marketization of knowledge and expertise, have hindered the civic and educational purposes of universities, and needs to be addressed (Astin, 2000; Bok, 2003; Chickering, et. al, 2015; Lewis, 2006). Newman (2000), a founder of Campus Compact, argues that universities have earned their privileged position in society by focusing on the needs of society rather than self-gain, and thus are given responsibility. As higher education becomes more "closely linked with for-profit activities and market forces, its special status is endangered" (cited in Zlotkowski, 2013, p. 21). Competitive forces can inhibit progressive pedagogies and new research methods (Edgerton, 1997). A focus on individual success, isolation, and privatization creates a culture in which stakeholders feel distanced from decision-making, assuming that the "best and brightest" have things in hand (Boyte and Fretz, 2011, p. 84). Harry Lewis, a former Harvard College dean writes in Excellence Without a Soul (2006) that the "superimposition of economic motivations on ivory-tower themes has exposed a university without a larger sense of educational purpose or a connection to its principal constituents" (pp. 2-3). Lewis argues that Harvard has responded to market demands for more specialized education, and has led other universities in this shift. A civic approach to university education acknowledges the importance of career preparation and disciplinary knowledge but it also addresses the 
relational and moral domains necessary to citizenship building (Astin, 2000; Chickering, et. al, 2015; Lewis, 2006).

Furthermore, questioning a neoliberal frame for higher education reveals important questions and areas for study. In questioning the assumptions of neoliberalism, we can also question a market-based lens that sees students as blank slates to whom commercially-valuable information can be added. Further, we can examine where this problematic lens may have been applied to models of civic education. Some models for civic engagement education have tended to see students as blank slates that must be given civic values and dispositions. Other models go so far as to assume that students are apathetic. Scholars, however, in both Psychology and Political Science have argued that apathy is not an adequate explanation for civically disengaged behaviors (Holbein \& Hillygus, 2020; Lertzman, 2015). Setting aside a neoliberal lens on civic education, we can instead see students as intrinsically motivated to act on behalf of what matters to them. Taking this view allows for a significant reframing of the central mandate of civic education: Rather than asking how to add civic values and dispositions onto students, we can inquire into how to relieve students from what hinders them in their instincts toward engagement. While we have abundant sociological inquiry into the question of hinderances on an institutional level (e.g. Putnam, 2000), we have considerably less insight into how education can, given the unique difficulties that individual students face, begin to restore and renew intrinsic motivation toward civic engagement. 


\section{Furthering civic republican and critical citizenship education}

To summarize, the civic republican conception of citizenship has deep roots in American democracy and, along with the contemporary concept of critical citizenship, provides an important basis for civic engagement education. According to these conceptions, citizenship involves active, collaborative participation from values of communitarianism, trust, and social justice. To teach the skills of citizenship, education can draw on constructivist pedagogy that is seen to further the aims of empowerment and engagement. While scholars have developed a strong argument for the civic purpose of higher education, proponents of this aim face challenges in the form of neoliberal and positivist attitudes and policies, which devalue Homo Politicus and experiential knowledge. Moving forward, it will be important to further strengthen civic education in ways that respect and draw upon the unique assets and traditions of universities, while addressing both the civic dimensions of education and students' hinderances to engagement.

Civic republican and critical conceptions of citizenship include capacities such as care, trust, commitment and collaboration that connect to social and emotional dimensions of behavior and learning (Jagers, Rivas-Drake, \& Williams, 2019). The study of these noncognitive aspects of citizenship is currently being explored in emerging fields such as transformative social emotional learning (Jagers, Rivas-Drake, \& Williams, 2019) and healing centered engagement (Ginwright, 2018). Furthermore, experiences of wholeness, empathy, and belonging are, according to recent work, considered valuable in the college classroom as it is thought that these affective factors support cognitive growth 
(Hylton, 2018; Lalas et al., 2019; Kecskes, Nishishiba and Morgan, 2013; Klovenbach, 2000).

However, the important understanding of how social-emotional and other noncognitive dimensions of learning specifically relate to civic engagement has only initially been developed (Lin, Oxford \& Brantmeier, 2013). Scholars have developed a strong understanding of certain practices, such as service learning, that have been found to teach the skills of engagement (Bringle \& Hatcher, 1996; Jacoby, 1996). Typically, however, civic learning outcomes are seen as an implicit result of these educational practices. Scholarship has not revealed maps of civic learning that explicitly include noncognitive dimensions of engagement. Given that neoliberal and positivist thinking has tended to minimize the value of noncognitive learning in higher education, it is important to step back from these lenses, and take stock. From this vantage point, a question arises: How can civic republican and critical citizenship dispositions be taught most fully, while seeing students as intrinsically motivated? To explore this question also involves inquiry into: What insights about education practice might emerge from more deeply exploringand ideally, naming and mapping - the noncognitive capacities that appear to underlie critical and civic republican participation?

Several fields of study have been underutilized thus far in developing models of the noncognitive aspects of civic engagement education. These include areas such as contemplative practice in higher education, and Indigenous Knowledge relating to pedagogy, human development and engagement (Barbezat \& Bush, 2013; Madjidi \& Restoule, 2008; Toulouse, 2016). One body of work is particularly useful here as one of 
its primary aims has been to develop maps of learning and teaching from the holistic perspective (Mahmoudi, et al., 2012; Miller, 2007; Miller et al., 2005). Miller's (2005, 2007) work on holistic education has been cited and built upon in areas such as Indigenous pedagogy, integral transformative education, and embodied learning (e.g. Batacharya \& Wong, 2018; Ermine, 1995; Ferrer, Romero, \& Albareda, 2005). Further, holistic education can meet a key criterion emerging from the critique of neoliberalismthat students are seen as innately whole and intrinsically motivated. The following section discusses how holism and holistic education inform an evolving map of civic republican and critical citizenship education.

\section{Holism as a frame for civic engagement education}

Generally, holism refers to the perspective that separate aspects of something cannot be understood in isolation, but must be seen in context of the whole. Applied to education, holism implies consideration of all that comprises an individual, including the body, mind, emotions and spirit. Miller $(2007,2012)$ writes that holistic education "attempts to bring education into alignment with the fundamental realities of nature" with an understanding of nature as "interrelated and dynamic" (2007, p. 3). A direct response to fragmentation within and between people, communities, and nature, holistic education places balance, inclusion, and connection at the center of education. Miller (2012) makes the explicit connection between indigenous principles of education and the holistic approach, writing that there is overlap in three core ways - a mind/body/spirit focus, an assumption of the interconnectedness of all life, and a sense of sacredness inherent to humans and nature. Spirituality in the holistic education model is defined as "awe and 
reverence for life that arises from our relatedness to something both wonderful and mysterious" (Miller, 2007, p. 4). Forms of holism can be seen in some U.S. educational movements, including Transcendentalism, civil rights activist training, and the recent increase in Montessori, Waldorf, and Reggio Emilio-based independent and charter schools (Forbes \& Martin, 2004; Gura, 2007; Houck \& Dixon, 2006).

Important to defining "wholeness" is determining the dimensions or aspects of human beings that make up the whole. The primary model for this sees humans as comprised of four aspects - physical, emotional, mental, and spiritual (Armstrong, 1996; Burns, 2008; Miller, 2017). In terms of civic behavior, we can understand these four dimensions to be potentially involved. Physical factors affect wellbeing and capacity for participation (Menakem, 2017). Emotional factors can affect the capacity to be open and engage with current realities (Buissink-Smith, Mann, \& Shephard, 2011; Davidson, 2017). Mental factors shape what we assume to be possible and thus what we devote our energies toward (Ausubel, 1968; Gardner, 2006). Spiritual factors influence our sense of interconnection, belonging, and capacity for resilience and courage (Armon \& Armon, 2015; Pyles \& Adam, 2016; Shephard, 2008).

Armstrong (1996) has written about the Okanagan perspective on the holistic self. Armstrong argues that an indigenous view of humans and nature as inherently connected creates a different magnitude of responsibility and stewardship for the natural world. The Okanagan view of a human includes an awareness of four selves - a physical self, an emotional self, a mental self and a spiritual self. The physical self is a container and connection to the other selves. The emotional self is the connected self, that senses 
connection to others and nature and can respond from that awareness. The mental self is the "spark that ignites," or the aspect of self that is capable of fresh insight. It must be linked to the emotional self or it can be destructive. The spiritual self is "without substance while moving continuously outward" (p. 464). When the other selves quiet, they fuse, and the spiritual self —in its connection to all things—can hear and interpret information from its surroundings.

Burns (2015) draws on Armstrong's (1996) work and applies it to higher education pedagogy in the field of sustainability education. Burns argues that education of the whole self helps serve the transformative purposes of sustainability education in multiple important ways: "In order for leaners to be motivated and inspired to make sustainable changes in their lives and communities, they must be given the opportunity to learn with their whole selves” (p. 272). Rather than distract from course content, including the selves in design can inspire deeper engagement with the content, processes, context, and relationships that are part of the learning environment. Furthermore, this approach can support the aim of changing students' values and intentions toward more sustainable behaviors.

A holistic lens is a valuable tool for considering civic engagement in the civic republican tradition. With an explicit discussion of the holistic dimensions, we expand the terrain that can be mapped and included in educational models. While the consideration of noncognitive factors in political behavior seems to be growing (e.g. Holbein and Hillyguys, 2020), there remains much room to develop this work. One area in particular is the exploration of holistic strategies to teach students to confront their cognitive frames 
(Sears, 2014). Education literature suggests that students arrive in the classroom with cognitive schema that are resistant to change (Ausubel, 1968). As Gardner (2006) writes, "If one wants to educate for genuine understanding, then, it is important to identify these early representations, appreciate their power, and confront them directly and repeatedly" (p. 77). The implication of this for civic education is that students can develop more nuanced and sophisticated understandings, and learn to see "the internal contradictions in their own narratives as well as to explore the narratives of others" (Sears, 2014, p. 14). These critical awarenesses can lead to more informed and collaborative civic behavior. Holistic analysis implies that cognitive growth can be enhanced by engaging noncognitive dimensions in the learning process. A final argument for the application of holism to civic education is that we have some evidence to suggest that holistic approaches improve equity outcomes in higher education (Sanchez \& So, 2015). This is particularly important given the "profound engagement gap" affecting students from marginalized populations (Levinson, 2012, p. 32; Niemi, 2012).

IV. Conclusion: Toward a model of holistic civic engagement education in the university

Moving from the civic republican strand of thought, we see that civic engagement is multi-faceted in the sense that civic actions are connected to cognitive and noncognitive dimensions. We see that education for civic engagement is vitally important to prepare thoughtful and caring citizens, that higher education is a key context for this given its unique history and role, and that our practices could potentially be improved by designing with a holistic lens to explicitly develop the noncognitive skills of citizenship. There are significant potential gains, both for individuals and for our political community, 
from doing this, and from setting aside some of the ways that liberalism and positivism have shaped what we teach and how.

This dissertation contributes to our understanding of how civic republican engagement can be further taught in universities by using a holistic approach and focusing upon the restoration of intrinsic motivation. It does this though an action research study that assesses the impacts of incorporating a new model and curricular strategy into two college courses. The Model of Holistic Civic Engagement Education (HCEE) I present here is based upon a synthesis of literature from a variety of fields. This interdisciplinary literature, once organized according to a holistic framework, indicates that civic behaviors can best be encouraged through engaging students in fourdimensional transformative learning experiences. These experiences can potentially help ameliorate disengagement and restore some of students' innate capacity for engagement. I propose that this beneficial impact can be encouraged through assigning reflective narrative writing assignments, which guide students through a process of reconsidering past experiences of disengagement in order to negotiate a more empowered attitude toward future civic engagement. The key components of this approach that allow for renegotiation are self-empathy and vision. The re-engagement tool, as I term this specific curricular strategy of narrative writing, is presented and discussed along with the more general Model.

In order to assess the impacts of the tool and Model, I conducted an action research study. I revised two college courses to incorporate the Model and tool and collected data to inform how students responded. Action research, typically used to shed 
light upon social problems encountered by practitioners in their practice, allowed me to assess student learning by analyzing written work. Utilizing rubrics and qualitative data analysis informed by grounded theory, I identified themes in student writing that could inform a response to the two research questions: How does writing a sequence of engagement/service personal narratives impact undergraduates' capacity for holistic civic engagement? And, What learning did students demonstrate in relation to holistic civic engagement capacities and competencies? The results of this study indicate that the re-engagement tool indeed holds promise as a means for increasing civic engagement capacity through college courses. The results further suggest that the Model is a useful frame for course design, though because of its scope, significant further study is required to fully assess the Model's impacts.

\section{Layout of the Dissertation}

Chapter Two draws on a holistic lens and lays out how different fields of study have emerged from different notions of holism. The aim in doing this is to learn from existing scholarship, but particularly from fields and perspectives that have established the broadest models and guides for holistic learning. These fields' contributions become the basis for the Model of Holistic Civic Engagement Education and the re-engagement tool presented and discussed in the second part of Chapter Two. Chapter Three describes the study design — the application of this model to two study courses, and outlines the research methods, data collection, and analysis processes. Chapter Four describes the results of this study. It presents themes found in student work, illustration of those themes, and discusses how these findings speak to the research questions. Finally, 
Chapter Five discusses the significance of the findings for various contexts and considers important next steps for further research. 


\section{Chapter Two: Literature Review and Model of Holistic Civic Engagement Education}

Chapter One described the importance of educating for democratic participation in higher education contexts. It discussed the historical role of universities in preparing citizens to make informed political decisions in service of the common good. It described the current movement toward holistic understandings of civic engagement education. Finally, Chapter One proposed that further insight is needed into both holistic conceptions of civic engagement and holistic approaches to civic engagement education. This chapter provides further context relevant to addressing this need. It discusses the contributions of several fields of academic knowledge and some relevant aspects of Indigenous Knowledge. It then draws on analysis of these sources to propose a model for holistic civic engagement education for undergraduates.

\section{Perspectives on Civic Engagement Education}

Various fields of study have developed conceptions of effective civic engagement, the factors that enable it, and how to best teach university students to engage. Discussing these bodies of literature both provides needed context, and reveals core perspectives and assumptions typical to each approach. By looking at civic engagement education from multiple disciplinary perspectives, including Political Science, Public Administration, Community Psychology, Education, Women's Studies, and Indigenous Knowledge, we see both common ground and areas of divergence, and can also note important potential areas for development. 
To organize this examination of perspectives on civic engagement, I draw on the framework of holistic education. While some fields treat civic behavior as primarily the result of cognitive facets such as conviction or political knowledge, other fields tend to assume that emotional components such as belongingness, or spiritual factors such as interconnection, are relevant as well. In organizing this section based on how many holistic dimensions are typically acknowledged in a field, my intent is to create the most comprehensive map possible. Ultimately, I will argue that the broadest frameworks, that take into account more engagement factors, are most helpful going forward. These approaches - that include cognitive, emotional, behavioral and spiritual dimensions in their understanding of civic behavior and civic education — form the primary basis for my own model. This said, each scholarly tradition offers unique contributions that must be acknowledged and drawn upon. Table 2.1 summarizes the fields of study included in the literature review with the holistic dimensions the fields typically include.

Table 2.1: Types of Holism in Bodies of Literature

\begin{tabular}{|l|l|l|}
\hline \multicolumn{1}{|c|}{ Holism Type } & Dimensions Typically Considered & \multicolumn{1}{c|}{ Fields of Study } \\
\hline Two-part & Cognitive and Behavioral & $\begin{array}{l}\text { Political Science (Deliberative } \\
\text { Democracy Education) }\end{array}$ \\
\hline Three-part implicit & $\begin{array}{l}\text { Cognitive and Behavioral with } \\
\text { implicit Emotional }\end{array}$ & $\begin{array}{l}\text { Public Administration (Civic } \\
\text { Engagement Education) }\end{array}$ \\
\hline Three-part explicit & $\begin{array}{l}\text { Cognitive, Behavioral and } \\
\text { Emotional }\end{array}$ & $\begin{array}{l}\text { Community Psychology, Education } \\
\text { (Trauma-Informed Pedagogy) }\end{array}$ \\
\hline Four-part & $\begin{array}{l}\text { Cognitive, Behavioral, Emotional } \\
\text { and Spiritual }\end{array}$ & $\begin{array}{l}\text { Sustainability Education, Women's } \\
\text { Studies (Spiritual Activism) }\end{array}$ \\
\hline Four-part Systematic & $\begin{array}{l}\text { Cognitive, Behavioral, Emotional } \\
\text { and Spiritual }\end{array}$ & Indigenous Knowledge \\
\hline
\end{tabular}




\section{Two-part holism: Cognitive and behavioral}

Within Political Science, theorists focusing on deliberative democracy have begun building a conception of civic engagement education (Englund \& Solbrekke, 2014; Schoem \& Hurtado, 2001; Shaffer, 2014; Thomas \& Levine, 2011). "Deliberative democracy" refers to the inclusion of collaborative reasoning and decision making processes into governance. Deliberative processes can lead to more legitimacy (Fishkin, 1997; Fung \& Wright, 2003; Gutmann \& Thompson, 2009; Mansbridge, 1983) as well as increased trust in fellow citizens and government (Cunningham \& Leighninger, 2010). Education for deliberative democracy asserts a two-part holism — that the cognitive learning about deliberation will lead to changed civic behaviors in students. Deliberation requires reason-giving, open-mindedness, and an ability to integrate multiple truths (Friedman, 2007). Research exploring the skills needed for deliberation has led to general abilities such as communication skills and critical thinking (Thomas \& Levine, 2011). Deliberation experiences in universities can prepare graduates to be responsible professionals (Englund \& Solbrekke, 2014). This suggests that teaching deliberative skills is an important aim.

\section{Drawing on two-part holism}

In two-part holism, the emphasis is on the importance of the mind in shaping civic behavior. Civic engagement education is framed as the training of the mind to develop habits of openness, inquisitiveness, and critique. This development is key for civic life in order for citizens to contribute to policy decisions. They are better equipped to do this if taught strategies for analyzing the assumptions underlying policy options, and identifying 
unstated frameworks that shape the information and language shared with them (Friedman, 2007).

Three-part implicit holism: Cognitive, behavioral and implicit emotional

Within Public Administration, civic engagement is often understood as action that builds the capacity of the citizenry to make collective decisions (Brammer, et al., 2012). This stems from the political understanding that citizen participation is necessary to sustain democratic institutions (Putnam, 1994). Civic engagement, though it may be built through informal interactions, is significant in that it goes toward addressing core political questions of how to allocate resources and core governance questions of who decides what. Civil society - the array of organizations and associations that comprise a "third sector" independent from the public and private sectors - is an essential component of democratic societies (Bellah, et al., 2007; O’Connell, 1999; Putnam, 1994, 2001; Sandel, 1998). Civil society is seen as a context for citizen participation.

Civic capacity is the ability of individuals and organizations to participate in civil society (Williams, Shinn, Nishishiba, and Morgan, 2002). More specifically, civic capacity is seen as:

the beliefs, knowledge, and skills necessary for individual citizens (including students), social organizations in the private and nonprofit sectors, and formal institutions of governance to work together in a way that enhances the collective ability of local communities to become more self-consciously directed in shaping their futures (p. 243). 
Stone (2001) adopts a narrower definition that civic capacity is found in individuals' ability to consider the good of the whole — it is "the extent to which different sectorsbusiness, parents, educators, state and local officeholders, non-profits and others-come together to act around matters of community-wide import" (p. 596). While the broader definition is more commonly used, it is useful to recall Stone's addition that civic capacity be not only in service of communities shaping their futures, but that these collective efforts that are of "community-wide import." Echoing this, Sirianni and Friedland (2005) write that "Democracy is, in some fundamental sense, the shared work of citizens acting pragmatically to solve public problems and to build a commonwealth" (p. 135). The civic capacity argument emphasizes two essential components to civic engagement—citizens' ability to act collectively, and their ability to consider their shared future (Banyan, 2014). These abilities involve complex sub-abilities that lie in the affective and other dimensions (Pyles \& Adam, 2016). Teaching these subabilities requires we acknowledge them head-on; as they are typically less valued in academe, they are easily overlooked when only seen together with the cognitive (Shephard, 2008).

Another relevant concept within Public Administration is that of New Public Governance. This framework stresses that public leadership takes place in complex and unpredictable contexts, and argues that leadership training for new public governance should involve tools for strategic thinking and foresight (Magis, Ingle and Duc, 2013; Rittel and Weber, 1973; Wheatley, 2006). However, in addition to cognitive skills, this sub-field asserts that relational skills such as interpersonal communication, ability to 
build trust, communication, and political sensitivity are essential (Lazenby, 2014).

Additionally, public administrators in the NPG context are "polity leaders"- those "guided by the moral ends of the communities they serve (Morgan, 2013, p. 263). Public leaders also take initiative, facilitate dialogue, flexibly adjust, and balance multiple roles. In valuing ethics, relational skills, and strategic adaptability for new public governance leadership, these scholars value but tend to underemphasize emotional skills.

\section{Educational Implications}

Some scholars within Public Administration address civic engagement in higher education (Battistoni, 2017; Boyte, 2015; Jacoby, 2009; Zlotkowski, 2011). Much of this work falls into the category of three-part implicit holism. This body of work acknowledges the importance of the affective dimension but tends to see affective skills as following automatically from cognitive development. The learning outcomes of civic engagement education here use both mental and emotional language (Boyte, et al., 2014). Emotional skills are thus valued, but not explicitly. They are taught through the key pedagogical practices of community-based learning and group processes, but not parsed out from what are assumed to be the core motivating aims of teaching critical thinking and civic convictions. Though this conflation may not seem problematic — and indeed community-based learning is an essential pedagogy for all dimensions of civic development (Astin, et al., 2000; Battistoni, 2017; Lovat \& Clement, 2016)—it keeps us from a purposeful mapping of the emotional components of civic learning. 


\section{Drawing from three-part implicit holism}

While this field has done essential work to expand the notion of civic skills beyond the mental and analytical, more development of these ideas is needed. Ehrlich (2009) defines civic learning as:

coming to understand how a community functions, what problems it faces, the richness of its diversity, the need for individual commitments of time and energy to enhance community life, and most of all, the importance of working as a community to resolve community concerns (p. vi).

Jacoby (2009) enumerates civic skills as: active listening, deliberation, engaging diverse perspectives, collaboration, creative problem solving, civility, ethical decision making, and information literacy. Saltmarsh (2011) defines civic learning as: knowledge from both academic and community sources of history and politics, skills of critical thinking and problem solving, communication, civic imagination and creativity, collective action, coalition building, and organizational analysis, and values of justice, inclusion and participation. These examples are typical of a conception of civic skills as both analytic and affective.

These affective skills are not always taught in current modes of higher education pedagogy, but they could be included more broadly. Specifically, the skills that would help students become effective in their civic work would teach them to observe their own civic actions, identify their challenges - including emotional challenges keeping them from meeting their goals, such as fear, overwhelm, resentment, or disappointment—and address them. Methods for teaching students how to identify challenges with the 
emotional aspects of engagement, and to reconcile with internal conflicts and feelings that make commitment and follow-through toward desired civic aims more difficult, would be a valuable contribution to the field of civic engagement education.

In addition to addressing affective obstacles to action, three-part implicit holism reveals another gap in the teaching of noncognitive aspects of engagement. These scholars often make reference to the goal of developing students' care for the common good. But the literature in Public Administration does not offer a full analysis of what it means to develop care in higher education settings. It is assumed that teaching students about injustice, and facilitating their interaction with diverse communities, will serve this function. While this may be so for many students, this approach tends to assume students are privileged and community work is with those less privileged. There could be more attention paid to the need to help students — especially public university studentsdevelop their own political voice and sense of efficacy. Learning to care for their own communities and selves can result in valuable civic action. It can also help develop the capacity to care for other communities. Because care for self is related to care for community, "self-care" can be seen as important for civic engagement (Reiff \& Keene, 2012). In essence, self-care involves making choices that include self-interest in a balanced way. Rather than martyrdom or sacrifice, which can be unsustainable, a selfcare approach to political action means combining self-advocacy, conducting an honest assessment of what each individual can sustainably commit to, and attention to community or group needs (Lin \& Oxford, 2013). 


\section{Three-part holism: Cognitive, behavioral, and explicit emotional}

Several fields, such as critical social work, community psychology, and AfricanAmerican studies, base their models of civic engagement on an explicitly three-part notion of holism (Christens, Winn \& Duke, 2016; Pyles \& Adam, 2016; Watts \& Flanagan, 2007). These disciplines typically assume that civic engagement occurs in society in a context of power inequality. Because of this assumption, scholars tend to view engagement — particularly the engagement of members of marginalized groups —as explicit efforts to create a more egalitarian distribution of power and resources (Hope \& Jagers, 2014; Watts, Griffith, \& Abdul-Adi). While holding fast to the insights from the field of civic engagement education, particularly its grounding in democratic theories and processes, it is necessary to include these critical perspectives. Because of growing political and economic inequality (Reich, 2015), it is useful to look at concepts and strategies that have emerged out of an explicit reckoning with this (Ryoo, et al., 2009). In these academic fields, engagement is seen as requiring an elevated awareness of purpose, a clear stance as part of a community with shared concerns, and of one's fundamental deservingness as a member of the polity. Education research has shown that social and emotional factors influence cognitive function (Immordino-Yang, 2016). Because the act of engaging requires members of marginalized communities to claim a political voice in the context of discouragement, there is a strong sense in these fields that emotional components of engagement are essential to study and teach (Freire, 1970).

In writing about teaching engagement to undergraduates, some Community Psychology scholars have put forth an approach to civic education. They have developed 
two concepts in particular to discuss this: "political efficacy" and "empowerment." Political efficacy refers to the sense an individual has of her capacity to influence others in the political world (Watts, Diemer \& Voight, 2011). This is an explicitly emotional component that accompanies the cognitive component of critical reflection (Christens, Winn, \& Duke, 2015). "Empowerment" is often used interchangeably in the literature, and refers to the perception and feeling that one's active participation can influence decision making (Zimmerman and Zahniser, 1991). While civic engagement education tends to focus on behavioral outcomes and the cognitive learning that leads to desirable behaviors (as seen in the broader context of democratic participation as a key input for democratic governance) scholars writing in community psychology and other critical disciplines see behavior as inextricably connected to emotion as well as cognition.

\section{Considering apathy}

Another scholarly approach to including affect in our understanding of engagement comes from another sub-field of psychology. One recent study by Lertzman (2015), drawing on the field of ecopsychology, is particularly relevant to conceptualizing holistic civic engagement education. Writing about our capacity to engage with environmental issues, Lertzman (2015) argues that we must look at unconscious psychic activity at play: "No longer can we focus on the 'gap between values and actions' and presume that how we behave is a straightforward expression of our concerns, beliefs and values" (Lertzman, 2015, p.145). Lertzman argues that apathy is much more complex than a lack of care, and can be better understood through factors such as "environmental melancholia," in which humans' natural desire to intervene is obstructed by mourning and 
overwhelm. For Lertzman, the implication of adding the psychosocial dimension to our understanding of engagement is that we can "meet people with far greater levels of attunement, compassion and authenticity" (Lertzman, 2015, p. 145). Educators and environmentalists need to focus not only on the cognitive components of engagement and developing values, but on enabling people to experience themselves as agents. In higher education, this means supporting students to create, use their voices, and discern how they wish to express their innate human desire for efficacy.

\section{Considering trauma}

Two other approaches fit into the three-part implicit holism category in their treatment of civic education. Both of these areas - trauma-informed pedagogy and healing centered engagement - argue that education can be more effective and engaging if it accounts for students' past challenges. The emphasis on encouraging student participation is seen as political, as classroom engagement can contribute to students' motivation to participate more broadly in the civic sphere (Davidson, 2017; Ginwright, 2018).

\section{Trauma-informed pedagogy}

Most frequently, the phrase "trauma-informed" is applied to health care. However, a movement has built over the last decade to apply this framework to higher education. This movement's premise is that past traumas impact students' capacity for learning, and that better learning outcomes could be achieved by establishing organizational and pedagogical practices to mitigate this impact (Butler, Critelli, \& Rinfrette, 2011; Harris \& Fallot, 2001; McInerney \& McKlindon, 2014). Trauma-informed pedagogy is useful to 
consider, as it speaks to students' capacity to fully engage with their courses and learning opportunities. This in turn could support future civic engagement (Saltmarsh, 2011).

The trauma-informed approach was largely instigated by a key study showing that two thirds of participants had experienced at least one adverse childhood experience (such as losing a parent, community violence, or abuse), and when more of these experiences were reported, this correlated with dramatically poorer health outcomes (Anda \& Felitti, 1998). In its broad meaning, trauma-informed care refers to:

A set of principles that guide and direct how we view the impact of severe harm on young people's mental, physical, and emotional health. Trauma informed care encourages support and treatment to the whole person, rather than focusing on only treating individual symptoms or specific behaviors (Davidson, 2017). Rather than avoiding trauma, this approach advocates for skillful confrontations of traumas. Avenues such as peer support and community organizing are seen to help reframe community narratives and strengthen a sense of self-determination (Falkenburger, Arena, \& Wolin, 2018).

A university can be an important context to which to apply a trauma-informed lens. Trauma causes physiological changes to the developing brain and losses and delays in physical, emotional and social development and learning (Burke et al., 2011). Harm to social relationships and engagement school have also been shown to result from exposure to trauma (Harvard University, 2007; van der Kolk, 2003). Even after traumatic events are over, students can continue to be impacted, responding as if the trauma were continuing by operating with a base level of vigilance, fear, or alarm, which impacts their 
capacity for curiosity, exploration and learning (Hoch et al., 2015). By the time students arrive at college, 66 to 85 percent report exposure to traumatic events (Read et al., 2011; Smyth et al., 2008). Additionally, ethnic minority status as well as low socioeconomic status have been revealed as risk factors for trauma exposure (Read et al., 2011).

Scholars have proposed strategies to mitigate the impact of past trauma on student learning. Many of these strategies would be implemented by institutions, including increasing access to mental healthcare, and funding programs to increase social support and "embeddedness" (Galatzer-Levy et al., 2012). Individual educators can also adjust practices as well. Wolpow et al. (2009) give six principles to inform interactions with students who may have experienced trauma: (1) always empower students, (2) express unconditional positive regard, (3) maintain high expectations, (4) check assumptions, observe, and question, (5) help students develop social skills, and (6) provide guided opportunities for effective participation. The study of trauma-informed pedagogy in higher education is a recent development; the field has begun by establishing the need for awareness and creating basic guidelines for the college environment. It has not yet considered if and how academic curricula could form part of the strategy for mitigating the widespread impacts of trauma (Carello and Butler, 2014).

\section{Healing centered engagement}

Ginwright (2018) has written about "healing-centered engagement." A professor of Education and African American Studies, Ginwright primarily writes about youth development theory and practice in working with Black youth. Ginwright argues that trauma-informed care, while useful in its assumption that "disruptive behavior is the 
symptom of a deeper harm, rather than willful defiance, or disrespect," could be updated by including an understanding that students are more than their trauma, and can move past it (2018, para. 4). Ginwright tracks the intellectual development of healing-themed approaches to education, from the 1990s inception of "resiliency," to the early 2000s framing of "youth development." More recently, the impact of trauma has come under consideration. However, Ginwright argues that there are two key issues with this framing. First, thinking in terms of trauma-informed care does not allow sufficient space to consider collective trauma. Second the trauma-informed lens tilts toward a deficit-based, rather than asset-driven approach; it can subtly affirm to students "you are the worst thing that ever happened to you." Ginwright urges a "healing centered approach" that "moves beyond 'what happened to you' to 'what's right with you' and views those exposed to trauma as agents in the creation of their own well-being rather than victims of traumatic events" (2018, para. 12). Furthermore, there must be, embedded in our approach to students, a core belief in "interdependence, collective engagement and service to others" (Ginwright, 2018, para. 12).

As a means to further the healing centered approach, Ginwright provides four general principles of healing centered engagement. First, healing centered engagement is explicitly political, rather than clinical: "Healing from trauma is found in an awareness and actions that address the conditions that created the trauma in the first place." Second, healing centered engagement is culturally grounded and views healing as the restoration of identity: "Healing centered engagement is the result of building a healthy identity, and a sense of belonging." Third, healing centered engagement is asset driven and focuses on 
the well-being we want, rather than symptoms we want to suppress, with a

"salutogenic approach focusing on how to foster and sustain well-being." Finally, healing centered engagement supports adult providers with their own healing: "Healing centered engagement has an explicit focus on restoring, and sustaining the adults who attempt to heal youth—a healing the healers approach" (Ginwright, 2018, para. 13-16). Ginwright's emphases on the political rather than clinical approach, the importance of a sense of belonging, and the salutogenic approach are all relevant in developing a healing centered civic engagement curriculum.

\section{Drawing from three-part explicit holism}

We can draw several key implications from this literature toward enumerating core holistic civic competencies. First, Community Psychology and other fields emphasize the importance of analyzing power dynamics as part of critical thinking. This implies that there is an important interplay between the mental and emotional dimensions - mental analysis can identify and generalize about power in society which can relieve some of the emotional disempowerment felt when engagement is unsuccessful because of inequities. In other words, students may arrive at the university feeling disempowered, which discourages them from civic engagement. But, as Christens, Winn \& Duke (2016) and other point out, if they learn to see larger patterns in society that contributed to their feeling of disempowerment, this can transform into a political challenge with potential for redress, rather than an individual deficiency that cannot be changed. Based on this literature's insights about political efficacy, teaching students to manage the emotional work of civic engagement is partly about helping them restore confidence in their own 
efficacy. This happens by both reconciling with the past and preparing to meet future challenges. Civic engagement requires these two pieces of emotional capacity-the confidence to take action, and the skill to address what inevitably arises in taking those actions.

In drawing upon Ginwright's scholarship for this study, three things are important to consider. First, he is writing in the context of community-based youth development, not the formal higher education context. Second, Ginwright is primarily focused on the engagement of African American youth given how poverty and racism have threatened their participation in vibrant community. The third takeaway is the importance of hope. This relates to this study, as many young people can benefit from developing hope (Orr, 2011). Ginwright writes that hope is "an important prerequisite for meaningful civic engagement and social change" and that "the first step in making change is to imagine new possibilities" (para. 5). He states that further research should "unpack less-known dimensions of civic engagement" such as hope (2011, para. 13). Ginwright's perspective on hope and healing centered engagement can inform our criteria for effective holistic civic engagement education; effective HCEE should help students imagine new possibilities. It should aim for healing and, ultimately, for "collective optimism and a transformation of spirit that, over time, contributes to healthy, vibrant community life" (Ginwright, 2011, para. 5).

Four-part holism: Cognitive, behavioral, emotional and spiritual

Several fields of study add the spiritual dimension to their models of education for civic engagement. These include contemplative practices in higher education, 
sustainability leadership education, spiritual activism, and Indigenous Knowledge. This section on four-part holism includes a definition and discussion of spirituality in higher education.

The role of spirituality in teaching civic engagement in higher education

Broadly speaking, spirituality can be defined as:

A way of life that affects and includes every moment of existence. It is at once a contemplative attitude, a disposition to a life of depth, and the search for ultimate meaning, direction, and belonging. The spiritual person is committed to growth as an essential ongoing life goal. To be spiritual requires us to stand on our own two feet while being nurtured and supported by our tradition, if we are fortunate enough to have one (Teasdale, 1999, pp. 17-18).

Spirituality may or may not be expressed through religion. In higher education, discourse around spirituality can be framed in terms of concepts such as authenticity, purpose, meaning, integrity, wisdom, values and integrity to stay within the legitimate concerns of moral development and away from indoctrination (Chickering, et. al, 2006).

It can be useful to include elements of spirituality in higher education for several reasons. First, spirituality is seen as a means for countering the current emphasis in universities upon rational empiricism, individualism, and increasing focus on professional training (Glazer, 1999; Palmer \& Zajonc, 2010). Second, one of the aims of higher education is helping students live authentically, and this is supported by developing a spiritual perspective in which we can risk exposing our assumptions, preconditions, and mental models (Chickering, et. al, 2006). Third, spiritual frames for 
education can lead to a sense of connection to other humans and other life forms, which can fuel civic leadership (Hargreaves and Fink, 2012). Finally, spiritual practices that build mindfulness in higher education can have multiple benefits such as openness to unknown others and increased creativity in problem solving (Barbezat and Bush, 2013).

Because my focus is on civic engagement (rather than on personal fulfillment or self-actualization more generally), I conceive of these broader benefits as two spiritualcivic capacities. The first is developing a sense of interconnectedness. This is important in civic engagement because a civic republican approach to engagement asks us to learn to consider the needs of the whole, trusting in generative collective processes, and holding an awareness that seeking the public good also benefits individual citizens. The second is acting out of trust in a larger process. This is important in engagement because participating in movements or endeavors requires many actions by individuals, and these actions may not have a discernible desired outcome. Moving toward a shared vision as part of a larger process can fuel sustainable engagement in the face of adversity.

\section{Contemplative practices in higher education}

The field of contemplative education examines the benefits and challenges of integrating practices such as mindfulness, introspection, and compassion into traditional modes of teaching (Barbezat \& Bush, 2013). A recent but substantial sub-field focuses on higher education, asserting that if integrated skillfully, and in a non-sectarian and inclusive fashion, contemplative practices can enhance learning across the disciplines as well as students' ethical practice post-graduation (Barbezat \& Bush, 2013; Eaton, et al., 2013; Palmer \& Zajonc, 2010; Ragoonaden, 2015; Rockefeller, 1994; Sanders, 2013; 
Shapiro, Brown \& Austin, 2011). The potential for contemplative practices in higher education to bridge theory and practice could be relevant in civic education, in which sensing diverse human experience while also engaging in generalization and policy-level thinking is a challenging and essential skill (Chesley \& Wylson, 2016). These approaches also value the awareness of oneself as part of a whole whose wellbeing is mutually dependent. This can open the way for a new mode of thinking - a mode in which root (mental model) level cultural assumptions (e.g. individualism) can be set aside long enough to envision and commit to alternatives (Wals \& Corcoran, 2012).

Another key potential of this approach lies at the epistemological level—students who are encouraged to attend to their own inner experience learn not only from reflection itself, but that the awareness and commitments that emerge from their lived experience matter (Ergas, 2016). Because an essential mechanism of oppressive structures is the invalidation of people's life experience, this is indeed significant (Freire, 1970). Empirically, we see that certain kinds of meditation enhance the ability to see another's perspective (Barbezat and Bush, 2013). Part of civic thinking is learning to hold one's perspective in mind while extending cognitively and emotionally to others. It is thus necessary to appreciate a basic validity of human experience and perspective- - despite cultural messages that assign more value to some life circumstances and choices than others. Valuing one's internal life is a prerequisite for curiosity, openness, and compassion, both to self and others (Neff, 2011). Pursuing collective political goals is inherently uncertain and challenging. Self-compassion, which feeds a "growth mindset" more resilient to failure, has high utility (Dweck, 2016; Neff, 2011). 
The final relevant argument made in the field is that emotions significantly effect decision making (Barbezat and Bush, 2013). Emotional and empathetic processes can be taught and learned, and have clear measurable effects on neurology. Studies have shown that certain meditations affect how people respond to unknown others, a process highly relevant to civic functioning (Barbezat \& Bush, 2013). Given the role of emotions in political thinking, it is important to learn appropriate and relevant skills—-by means of effective pedagogy—-for emotional awareness and social connection as part of an education (Immordino-Yang \& Damasio, 2007).

\section{Sustainability Education}

While not typically framed as education for civic engagement, the field of sustainability in higher education - a sub-field situated at the intersection of sustainable development and higher education policy—addresses the same core aims of preparing students for participating toward the common good. While some programs focus on institutional policies, and others on environmental science, the approach that is relevant here is one that comes out of transformative education (Shephard, 2008). The study of political engagement and the study of education have divergent epistemological and ontological foundations. Scholars have not substantively bridged this gap, and there is much that each field can learn from the other. While political engagement offers insight into mechanisms of change and resource allocation in a democratic context, education for sustainability reveals insights on how people come to the capacity for advocacy and informed input. 
Some sustainability education theorists take a four-part holistic approach, integrating noncognitive concepts such as adaptability, relational components, interconnectedness, compassion and care (Beer et al., 2015; Burns, 2016; Burns \& Briley, 2015; Sterling, 2002). These scholars tend to share an assumption that "'Business as usual' will not work" - that paradigm-level change is needed to create sustainable communities, and that a specific educational pedagogy is required to meet this demand (Capra, 2004; Sterling, 2004; Sterling, Jones, \& Selby, 2010; Thomashow, 1995). Because current systems create a fundamentally unsustainable environmental and social reality, sustainability leaders must be able to conceive of approaches and policies that draw on different resources and incentives. Civic engagement, according to this conceptualization, becomes a set of engagement efforts that reject the current economic paradigm and create new sustainable modes.

Additionally, for many sustainability education scholars, the biological interconnection of life on earth serves as an impetus to embrace a philosophy of care and interdependence (Armon \& Armon, 2015). It is not uncommon among these scholars to urge faculty toward "guiding students toward an intimate relationship with the Earth" (Berry, 1999, p. x). This relationship often goes deeper than that of inhabitant to planet. The value of the earth itself is elevated and merits an open, listening stance from humans (Armstrong, 2008; Vaughan-Lee, 2013). The earth's cycles of regeneration become a model to study (Armon \& Armon, 2015; Hemenway, 2015; Krasny, Lundholm \& Plummer, 2010). Buddhist and other spiritual values are seen by some to support sustained effort, compassion, and creativity (Macy \& Brown, 2014). Compassion, in 
particular, is seen as a key strategic approach for advocating for sustainable change, as it supports advocates in avoiding adversarial approaches that are more likely to be rejected, and also in reducing burnout in a context of inevitable difficulty (Edwards and Post, 2008).

\section{Transformative Learning}

Transformative learning is called for when the aims of education include a capacity to question dominant paradigms and envision more sustainable ones (Burns, 2011; Sterling, 2002). Here, "transformative education" means educating for transformation on several levels. Mental transformation involves questioning mental models and paradigms that shape unsustainable behaviors and culture. Emotional transformation means bringing mindfulness and resolution to problematic emotional patterns that create blind spots in our behavior. Physical transformation, while not traditionally an emphasis of higher education, is important as well and is comprised of both behavior change and improvements in wellbeing (Burns, 2016; Miller \& Nigh, 2017). Spiritual transformation, perhaps the most difficult to observe and record, refers to the improved capacity for compassion, wisdom, vision and love-motivated action (O'Sullivan, 2002). Without transformation as a goal, it is likely that civic learning in the university will not serve students in life.

Transformative learning is a well-established concept in the literature of Education that is facilitated through an array of studied pedagogical strategies (Baumgartner, 2001; Sterling, 2002). Transformational civic learning, encompassing multiple layers, requires the same basic curricular components, such as experiential 
teaching methods, community building and a culture of vulnerability. Transformational civic learning particularly requires pedagogy and curricula that can achieve a key paradoxical function: they must contain and direct the multi-dimensional trajectory of learning, while simultaneously remaining open to the chaotic unfolding of the process in the complex systemic context.

\section{Indigenous Knowledge}

It is important to include Indigenous knowledge as a source of insight in building a conception of holistic civic engagement and mapping the aims of holistic civic engagement education. Indigenous knowledge offers useful perspectives on what constitutes effective participation in community and how individuals build this capacity. Battiste (Mi’kmaq scholar) (2002) defines Indigenous knowledge as comprising “all knowledge pertaining to a particular people and its territory, the nature of use of which has been transmitted from generation to generation" (p. 6). Two themes are typically present in these systems of knowledge - all things are animate and all things are interconnected (Couture, 1991; Ermine, 1995; Madjidi \& Restoule, 2008). Madjidi \& Restoule (2008) note in their discussion of indigenous ways of knowing and learning that these ways are not in diametric opposition to Eurocentric education, but rather, "Indigenous knowledge in fact reveals Eurocentric limitations by presenting a more holistic, developed form of knowledge" (p. 159). Battiste (2002) adds that this "fills the ethical and knowledge gaps in Eurocentric education, research and scholarship" (p. 4). In this way, Indigenous knowledge can contribute to a holistic understanding of civic engagement. 
Indigenous knowledge can be helpful for those seeking to create models that are grounded in sustainable mental models (Hall, 2008). Masemann (1990) notes that Indigenous knowledge and other alternative paradigms are "holistic, context dependent, and integrative. They propose ways in which society might be knit together again, not sundered apart” (p. 471). As Madjidi and Restoule (2008) write,

At a time of spiritual, ecological, and social crisis, the opportunity exists to turn toward Aboriginal holistic frameworks for knowing and learning, to help humanity develop of sense of respect and relationship with all Creation (p. 176). It is valuable to consider how Indigenous knowledge can inform our conception of civic engagement and shed light on the competencies that enable it.

Bell (2014) (Anishinaabe scholar) discusses how to include Indigenous knowledge in curriculum design, giving four key considerations: Indigenous knowledge is culture specific, ecological, contained within the people of a nation, and is epistemological. She writes:

It is necessary to consider Indigenous knowledge as a collection of knowledges from different Indigenous nations. Indigenous knowledge is therefore culture specific, contained within the local knowledge and worldview of the nation. It therefore also has to be ecological, where the knowledge is contained within the land of the geographic location of the nation. Knowledge is also contained within the people of the nation. Indigenous knowledge then becomes personal and generational, as there is a process of generational transmission. Indigenous 
knowledge is epistemological, in that each nation culturally determines for itself how it knows what it knows (para. 11).

In learning from Indigenous knowledge, we must be clear on what aspects of the body of knowledge are intended to extend to general contexts, and which aspects are tied to culture and place (or are simply not meant to be shared) (Castellano, 2000; Madjidi and Restoule, 2008). For this study, I draw on knowledge shared by Indigenous scholars through publications, in which the authors have specifically offered the knowledge as information for a wide audience to be applied to curriculum design.

\section{Medicine Wheels}

Medicine wheels are often used in bodies of Indigenous knowledge. Medicine wheels typically contain four (or six) stages arranged as a cycle around a circle (MoekePickering et al., 2006). The four stages are often connected to the cardinal directions, elements, seasons, or stages of life (Madjidi, \& Restoule, 2008). The stages can also be connected to animals or other culturally specific cosmological components. The medicine wheel is primarily associated with North American Plains cultures such as the Cree, Dakota and Blackfoot cultures, but similar concepts are used around the world, for instance by the Maori people (Madjidi and Restoule, 2008). Beaulieu (n.d.) notes that although "Medicine Wheel" is not an Indigenous term, it has been adopted and become an important way for Indigenous elders to share traditional knowledge.

Toulousse (2016) writes that the medicine wheel can also be referred to as "the living teachings." It is a "circle of life that is continuous and never-ending. It demonstrates that everything is connected and everything is sacred. All of life is equal. 
All of life is deserving of respect, care and love" (p. 7). Furthermore, Castellano (2000) writes that the medicine wheel

is not a model of rigid categorization...rather it is a model of balance...The medicine wheel teaches us to seek ways of incorporating the gifts of the other quadrants...Through the sharing of diverse gifts, balance is created in individual lives and in society as a whole (pp. 21-36).

Based in a worldview of interconnection and a trust in the value of each individual's gifts, the medicine wheel illuminates a "living" process by which individual gifts can be expressed and shared in the context of the whole.

\section{Medicine Wheels and pedagogical design}

In addition to embodying the values of wholeness and sacredness, the Medicine Wheel tool has another quality: "Just like a mirror can be used to see things not normally visible, Medicine Wheels can be used to help us see or understand things we can't quite see or understand because they are ideas and not physical objects." (Bopp, et al., 1984, p. 9. Several scholars have pointed to the unique potential of Medicine Wheels to help us understand the learning process, which indeed often contains elements that "we can't quite see.”

Medicine Wheels can be a key tool in mapping holistic learning processes, including processes of growing in capacity for civic engagement. Calliou (1995) writes that "Medicine Wheels can be pedagogical tools for teaching, learning, contemplating, and understanding our human journeys at individual, band/community, nation, global, and even cosmic levels" (p. 51). Bell (2014) adds that in many cultures, the Medicine 
Wheel "contains all of the traditional teachings and can therefore be used as a guide on any journey, including the educational process" (para. 2). Indigenous knowledge is heterogeneous and vast; there is commonality, however, in the perspective on education as a holistic and lifelong process (Castagno \& Brayboy, 2008; Overmars, 2010; Toulousse, 2016).

One of the most relevant aspects of the Medicine Wheel for this study of civic engagement education is its ability to model holistic processes of development and growth. Some scholars have connected the Medicine Wheel to both the holistic dimensions (physical, emotional, mental, spiritual) and to stages of the learning process (Bell, 2014; Madjigi and Restoule, 2008; Toulousse, 2016). Madjidi and Restoule (2008) note that the four directions on the Wheel each hold particular gifts, that "an individual has the potential to develop throughout a lifelong journey of learning" (p. 161). Furthermore, "the medicine wheel frames human development holistically," rather than viewing development only in intellectual terms. Madjidi and Restoule (2008) continue: "With developmental capacities falling in each area of the medicine wheel, corresponding pedagogical practices and educational objectives can be constructed" (p. 161).

Bell’s (2014) Medicine Wheel (Figure 2.1) explicitly connects educational stages to the four directions. From East to North, Bell (2014) identifies four stages of learning: Awareness, Understanding, Knowledge, and Wisdom. These stages relate to: "See it," "Relate to it," "Figure it out," and "Do it." Bell elaborates: "In the east, the gift of vision is found, where one is able to see. In the south, one spends time in which to relate to the vision. In the west, one uses the gift of reason to figure it out." Finally, and of particular 
relevance to this study, is that "In the north, one uses the gift of movement to do or actualize the vision. In-depth searching for knowledge is what leads to wisdom" (n.d. para. 2). While there is certainly overlap between Bell's model and Kolb's (1980) classic model of adult learning, the Medicine Wheel brings a different perspective. Kolb's model moves from concrete experience, to reflective observation, to abstract conceptualization, to active experimentation (Kolb, 1980). Bell's framing of stages emphasizes “seeing," and "relating." It also leaves room for noncognitive processes to drive the "figure it out" stage (versus Kolb’s “abstract conceptualization”).

Figure 2.1: The Medicine Wheel and Stages of Learning

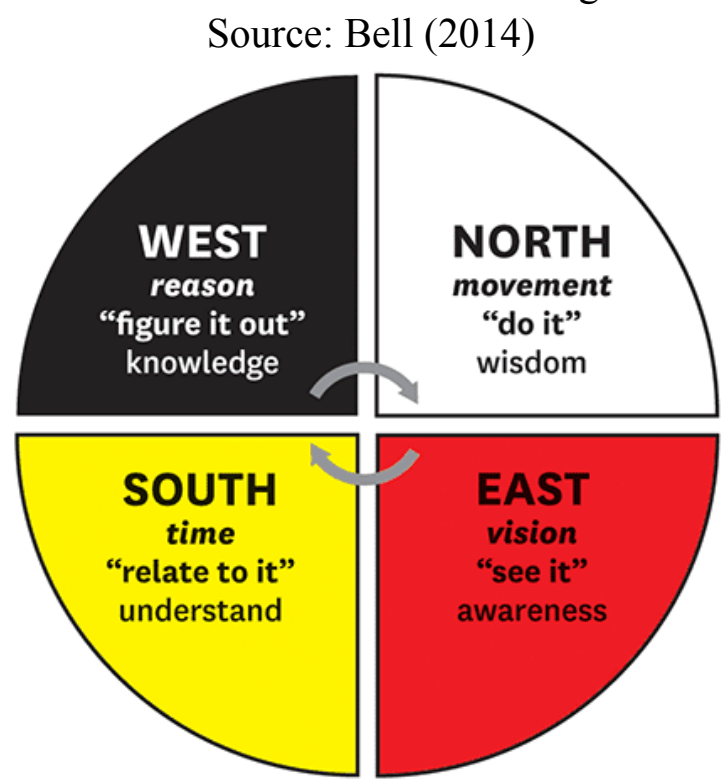

Figure 1: Gifts of the Four Directions

Of further relevance to this study, Bell's (2014) model extends to connect the stages of learning to the holistic dimensions (Figure 2.2). Bell's model is informed by Cree Elder Michael Thrasher. In this Wheel, the spiritual dimension is connected to the East, along with cultural and local knowledge, worldview, teachings, and vision. The East would seem to contain our core perspectives and mental models, clear sight, and the 
ability to envision possible futures. The South is connected to the physical dimension, time, and to ecological and land-based knowledge. It seems the South contains the ability to relate to one's environment and current reality. The West is related to the emotional dimension, and to the ability to reason with both one's heart and head, as well as engage in generational and personal learning. It seems that the West contains a capacity to make sense of one's experience, and emotionally relate to the individual self and to the generational context. Finally, the North connects to the mental dimension, and to culture, epistemology, and action. It would seem the North contains the ability to act out of respect and from a balanced understanding of what matters or what is real. These aspects of the directions inform what we might consider to be key components of a holistic learning process.

Figure 2.2: Holistic Dimensions and Learning Stages (Source: Bell, 2014)

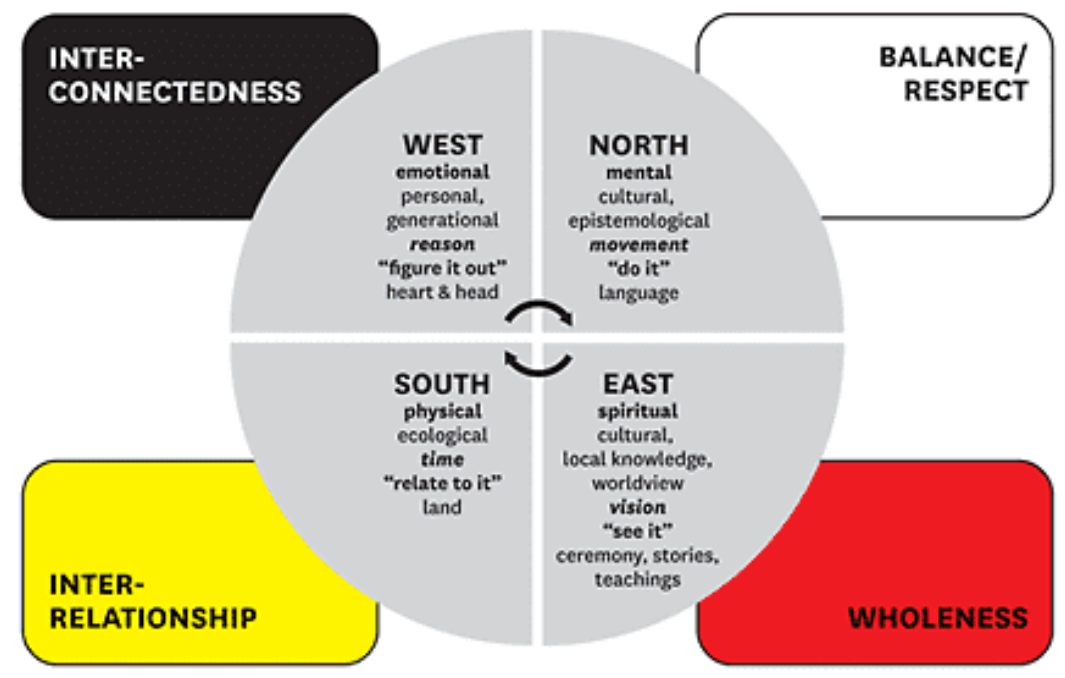

Additionally, Bell's (2014) Wheel has important implications for designing a curriculum intended to build capacity for civic engagement. Ultimately, the curriculum aims to enhance students' capacity for civic behavior. Because we assume a holistic 
model of behavior, in which emotional, mental and spiritual factors impact actions, it is useful to consider Bell's model mapping how the dimensions function as a system. This understanding contributes to our ability to map the emotional, mental and spiritual learning goals we would need to meet in order to hope for behavior change.

\section{Spiritual Activism}

Another key area for developing holistic civic engagement education is that of "spiritual activism." This term originated with feminist scholar Gloria Anzaldúa, author

of Borderlands (1987; Keating, 2008). Anzaldúa's and others' work suggests three principles for political engagement, which have implications for HCEE: (1) personal and political work are both necessary and investing in one area feeds the other, (2) cultivating compassion for oppressors is also strategic politically (Edwards \& Post, 2008), and (3) endeavors required for sustainable change require trust in a large-scale process and working toward desired visions rather than fighting against undesired realities (I. Merculieff, personal communication, April 17, 2015). It is useful to unpack these three principles and determine what can inform educational models.

The first, and most core, concept of spiritual activism is that all activism involves a feedback loop between self, community, and world. As one heals on the individual level (which is actually usually done in the context of a caring community), one builds motivation and inspiration to act publicly. Conversely, public action reveals to the individual her fears and personal limitations and leads her toward healing, reconciliation, forgiveness, and accessing internal reserves of motivation (Anzaldúa, 1987; Sheridan, 2012). Anzaldúa argues that self-change ("inner acts") and activism ("public acts") are 
the subjects of simultaneous focus, and that holding this dual intention brings transformation to both self and world. Scholars of "engaged spirituality" have argued that the seeming polarity of action and reflection in fact feed one another and interweave (Edwards \& Post, 2008; Palmer \& Zajonc, 2010). Anzaldúa writes that “Our spirituality [U.S. women of color] does not come from outside ourselves. It emerges when we listen to the 'small still voice' within us which can empower us to create actual change in the world" (In Keating, 2008, p. 195). Listening to this voice empowers people to expose injustice and create actual change. Furthermore, part of social transformation must necessarily occur within individuals who come to terms with their fear, confront their own wholeness, and encounter the motivation to create a society in which all can be whole (Sheridan, 2012).

A second aspect of spiritual activism emphasized by those who study and practice it is that it is seen as strategic (Sheridan, 2012). As with nonviolent resistance, there is an assertion that compassion for oppressors leads to more significant social change because it forces a focus on shared dignity and humanness. Compassion also creates space for the others to change, which leads to meeting equity goals more efficiently than attacking or labeling, which can lead to defensiveness and refusal to change. Practitioners argue that cultivating love for perpetrators is more likely if activists cultivate a love for humanity as a whole (Edwards \& Post, 2008). This is more easily accomplished with the spiritual perspective that everyone is connected and innately worthy of compassion.

The third aspect of spiritual activism is that it is useful to see one's work as part of a larger or longer-term vision, and thus focus more attentively on integrity of process than 
a specific outcome. Uncertainty and unanswered questions are a key part of the journey (Keating, 2008). Collins (1998), writing about Black women's social justice work, has called this "visionary pragmatism":

The notion of visionary pragmatism more closely approximates a creative tension symbolized by an ongoing journey. Arriving at some predetermined destination remains less important than struggling for some ethical end. Thus, although Black women's visionary pragmatism points to a vision, it doesn't prescribe a fixed end point of a universal truth. One never arrives but constantly strives (pp. 189-190). Vision is important to spiritual activism and civic engagement both.

\section{Drawing from four-part holism}

Considering civic learning through a four-dimensional lens means that we can broaden our map of effective civic engagement and the educational practices that might encourage it. The aims of education for civic republican participation include implicit affective and spiritual components, in addition to cognitive and behavioral ones. By drawing on bodies of knowledge that make these dimensions explicit, we increase our chances of identifying promising educational strategies. We see that interconnectedness could be a way of mapping the civic republican emphasis on the common good-because we are connected, the common good benefits us all. We see that mindfulness and introspection can be seen to have a place in higher education, and that these practices could encourage students to value themselves and their contributions more deeply. We see that a compassion can be both strategic and create space for new action, and that increased civic capacity may result best from transformative learning processes. We see 
that "public acts" relate to our "inner acts" and that spurring a cycle of reflection and action could strengthen the capacity for civic engagement. And we see that a visionorientation can spur empowered engagement. Finally, we see that Medicine Wheels can map complex holistic processes of transformative learning and that work by Indigenous scholars that include Medicine Wheel models have important implications for mapping holistic civic engagement. The following section synthesizes all of the literature reviewed in Part I. It generates a set of principles and considerations for designing a model of holistic civic engagement.

Part I Conclusion: Toward a Map of Holistic Civic Engagement Education Synthesizing the literature discussed in Part I, we can begin to coalesce a set of principles that a new model of holistic civic engagement should embody. We can also generate some criteria that curricula developed from the model should meet. This section presents five key points, emerging from the literature synthesis, that speak to the conceptualization, design, and criteria for a model of holistic civic engagement. These points are summarized in Table 2.2 and then described below. 
Table 2.2: Synthesis of Literature to Inform Model and Curriculum Design

\section{Summary of Synthesized Points}

1. Civic engagement behavior can be seen as being significantly impacted by the other holistic dimensions - the emotional, cognitive and spiritual.

2. Civic behavior, through a holistic lens, can be seen as an intrinsically motivated gifting of aspects of the self to community.

3. "Healing" can be a useful frame to apply to civic engagement education. A healing approach would focus on ameliorating the impacts of disengagement.

4. Compassion and empathy could be important goals of civic engagement education. Receiving compassion from the self or another, one is more easily able to move past suffering.

5. Vision is a key impetus for civic action and personal transformation.

First, according to the literature discussed, civic engagement behavior can be seen as being significantly impacted by the other holistic dimensions. This means that a model of civic engagement education should indicate how the dimensions are related. Curricula designed from the model can see behavior change as a primary outcome, yet should structure learning experiences that facilitate holistic growth on all dimensions in order to achieve this. Nearly all the literature we have discussed sees civic behavior holistically to some degree. For instance, deliberative democracy education sees it as the result of changed mental attitudes, Community psychology sees it as a result of both cognitive learning and emotional empowerment, and Contemplative education sees behavior change as enabled by spiritual dispositions such as interconnectedness.

The Indigenous knowledge literature is particularly informative about behavior in the context of the other dimensions. Indigenous scholar Absolon (1994) writes about the "Do it" stage of the Medicine Wheel: "the fourth direction involves creating a healing movement towards change - this is possible only when the other components have been 
acknowledged" (Absolon, 1994, p. 18). Bell (2014) elaborates further: "Moving into the 'doing' phase of the north requires taking the knowledge gained from all the directions and enacting that knowledge" (para. 7). Dumont (1992) concurs that the movement and action required by the northern direction asks us to move through each stage on the Wheel. Additionally, we have some sense that "through the spiritual or metaphysical worlds, one constructs meaning in the physical world" (Ermine, 1995, p. 107). We have a sense that civic engagement behavior could be deepened or strengthened by facilitating student engagement with the processes on all stages of the Wheel.

The second key point synthesized from the literature is that, given this ultimate focus on behavior change, it is also important to consider civic behavior itself through a holistic lens. According to these literatures, we can conceive of civic behavior as an intrinsically motivated gifting of aspects of the self to community. Toulousse (2016) writes that according to traditional Indigenous perspectives on citizenship "each individual is nurtured and positioned to develop their gifts as a human being” (para. 23). This follows from a worldview in which each individual has unique gifts, and that part of coming into adulthood is coming to recognize and use them for the benefit of the whole (Castellano, 2000). This conception is not the same as insistence on recognition; rather, it is about the act of giving (Welch \& Koth, 2009).

Similarly, "service," in the four-dimensional context is about allowing the flow of gift from a place of wholeness and respect (Remen, 1999). There is an understanding of a flow that moves through each person, in unique ways (Welch \& Koth, 2009). This perspective also then opens up questions about what can block or inhibit the flow of gift 
in a person's life. If we see each individual as innately capable of engagement and service, and as inherently connected to this larger flow of service and gift, then teaching civic behavior can be enhanced by addressing blocks and obstacles.

This indicates that any curricula developed from the model should take an assetbased, healing-based approach. This means that the curriculum treats students as innately whole, and sees their engagement as a natural expression of that wholeness. The curriculum helps students to address and ameliorate obstacles to this expression. This is distinct from a deficit-based approach in which students are seen as needing new values and habits of mind added to their awareness because they are seen as missing something. The implication, in sum, is that the model should show us what holistic engagement from a stance of wholeness might look like, and curricula should help address obstacles to engagement.

The third key point emerging from a synthesis of this literature is that "Healing" can be a useful frame to apply to civic engagement education, along with specific conditions. Ziegler (n.d.) writes that "When we stand back and look at all the ways individuals fail to reach their full potential in our culture, trauma stands out as the most significant common factor across settings" (p. 1). While two- and three-dimensional approaches to civic engagement education focus on forward momentum, and becoming more effective citizens, four-dimensional approaches are also suited to go - under certain conditions - into the past to investigate causes of disengagement (Carello \& Butler, 2014). Ginwright writes of healing centered engagement, "Healing from trauma is found in an awareness and actions that address the conditions that created the trauma in the first 
place” (2018, para. 13). Anzaldúa (1987) connects engagement behavior inherently to engaging with personal reconciliation. She sees public action as part of a feedback loop that also includes inward work to reflect, reconcile, and address internal obstacles.

Trauma-informed pedagogy acknowledges the heavy impacts of past experiences on student learning (Davidson, 2017). It recommends approaches for working around the limitations of trauma-induced challenges. This perspective is useful in supporting students to build the resiliency to engage in what can be uncertain and difficult political work. And, as Ginwright (2018) notes, helping students access and address issues could have an important role. The aim is not to avoid "triggers" entirely; the aim is to teach students ways to work through their challenges to put their values into action, and do so without re-traumatizing them (Carello and Butler, 2014). Simply airing, through writing and discussion - trauma histories is not an appropriate aim (Carello and Butler, 2014).

A healing centered approach to civic engagement education would mean several things. To justify asking students to reflect on difficulties, the curriculum would need to be flexible, the learning environment supportive, and the trajectory of the process would need to move students closer to resolution. A curriculum that could potentially lead to healing would encourage students to consider past struggles from an empowered and compassionate stance that could potentially lead to some resolution and increased capacity. A curriculum engaged with healing for civic engagement would concern itself with civic disengagement, support students in constructively addressing it, and teach them how to practice these processes of re-engagement in their future civic lives. Furthermore, healing disengagement can be seen as a four-dimensional endeavor. 
Education addressing disengagement can help students "establish a relationship with our whole being; this includes our spiritual, physical, mental, and emotional aspects" (Bell, 2014, para. 10).

The fourth point synthesized from the literature is that compassion could be an important goal of civic engagement education. Three-part approaches emphasize empathy — the capacity to imagine and care about others' experience (Brammer, et al., 2012). Four-part approaches add a value of compassion — an unconditional attitude of kindness, care, and wish for the end of any suffering others are experiencing (Welch \& Koth, 2009). Compassion often contains a sense of unconditional regard or unconditional worthiness (Lin, Oxford, \& Brantmeier, 2013). It also can sometimes contain an assumption of interconnection, that human suffering is a universal experience (Rosenberg, 2002). Importantly, compassion is seen to have a quality of healing — by receiving compassion from the self or another, one is more easily able to move past suffering (Neff, 2011).

The final point emerging from a synthesis of this literature is that vision is seen as a key impetus for civic action and personal transformation. An important aspect of civic engagement from the four-part perspective is that it is more powerful to move toward what is desired in the civic world, rather than move away from what is undesired (Merculieff, personal communication, April 17, 2015; Toulousse, 2016). This aligns with Ginwright's (2018) point that healing centered engagement focuses on the well-being we want as inspiration for action. Bell (2014), in discussing the Medicine Wheel's applicability to education, adds that, "By going to the east where one visions to transform that which is, one can actively create a better life for oneself and others" (para. 8). Vision 
is required as part of imagining new possibilities for radical change (Benhabib, 1992).

Within Indigenous knowledge, there is a sense that visions can be created, but also that they can be received; once a vision lands, an individual has a responsibility to it (Cajete, 1994). A model for holistic civic engagement should include a mapping of vision, and curricula should treat vision as an impetus for students to re-situate themselves in their civic worlds and adopt a more empowered stance.

Part I of this chapter summarized the conceptions of civic engagement and civic engagement education contributed by multiple fields of study. Part II of Chapter Two has two goals; it (1) synthesizes a model for holistic civic engagement education, and (2) draws from the model to propose an original instructional tool intended to develop a key underdeveloped holistic civic engagement competency.

\section{Modeling and Implementing Holistic Civic Engagement Education}

Section II has two components. The first is a proposed model of how holistic civic engagement stages and competencies might be mapped based on the literature review, and on Bell's (2014) Medicine Wheel. The second is a curricular tool to be used in college courses in order to help students grow in their capacity for constructive civic action. This tool guides students through a reflective process with the aim of reengagement. Bell (2014) writes:

Building from these understandings, Indigenous knowledge embraced by

Medicine Wheels can be defined as wholeness, interrelationships, interconnections, and balance/respect. Wholeness requires that we look in entireties; that the whole is greater than the sum of its parts, yet the parts cannot 
be fully seen until the shape of the whole can be seen. Interrelationship requires that we establish a personal relationship with the 'whole' - with all that surrounds us. In addition, we must establish a relationship with our whole being; this includes our spiritual, physical, mental, and emotional aspects. Interconnections create an environment which is mutually sustaining; where there is a transcending of logic and linear thought to reveal synthesis and dynamic interdependence. Balance and respect provide an order and structure to the whole and all its relationships and interconnections, while providing an appreciation for the 'awe' of it all (para. 10).

Bell's (2014) Wheel (Figure 2.3). called Gifts of the Four Directions, is at the center of the Model. The Model of HCEE (Figure 2.4) adds two components to an outer layer: One civic engagement capacity and two competencies that map to each stage of the wheel. The capacity is a relatively direct application of the Wheel stage to the civic sphere. The competencies (bolded) are skills, drawn from the literature review synthesis, that would help enable the capacity. They are components or building blocks for the capacities in the context of the higher education classroom. It is important to note here that though the model takes guidance and direction from a Medicine Wheel, is not itself a Wheel, as it does not originate from Indigenous knowledge. This section discusses the components of the model. 
Figure 2.3: Gifts of the Four Directions (Source: Bell, 2014)

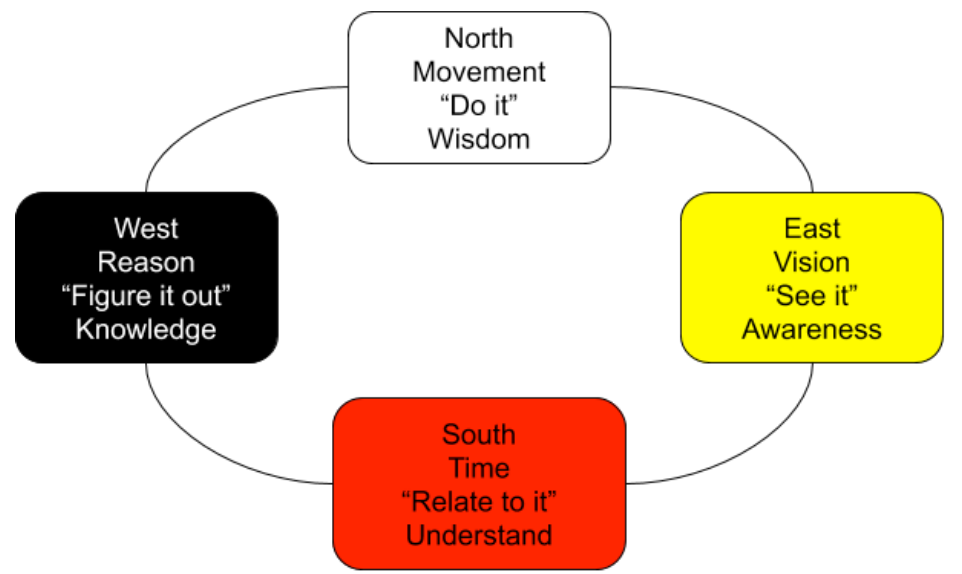

Figure 2.4: Model of Holistic Civic Engagement Education around Bell's Wheel

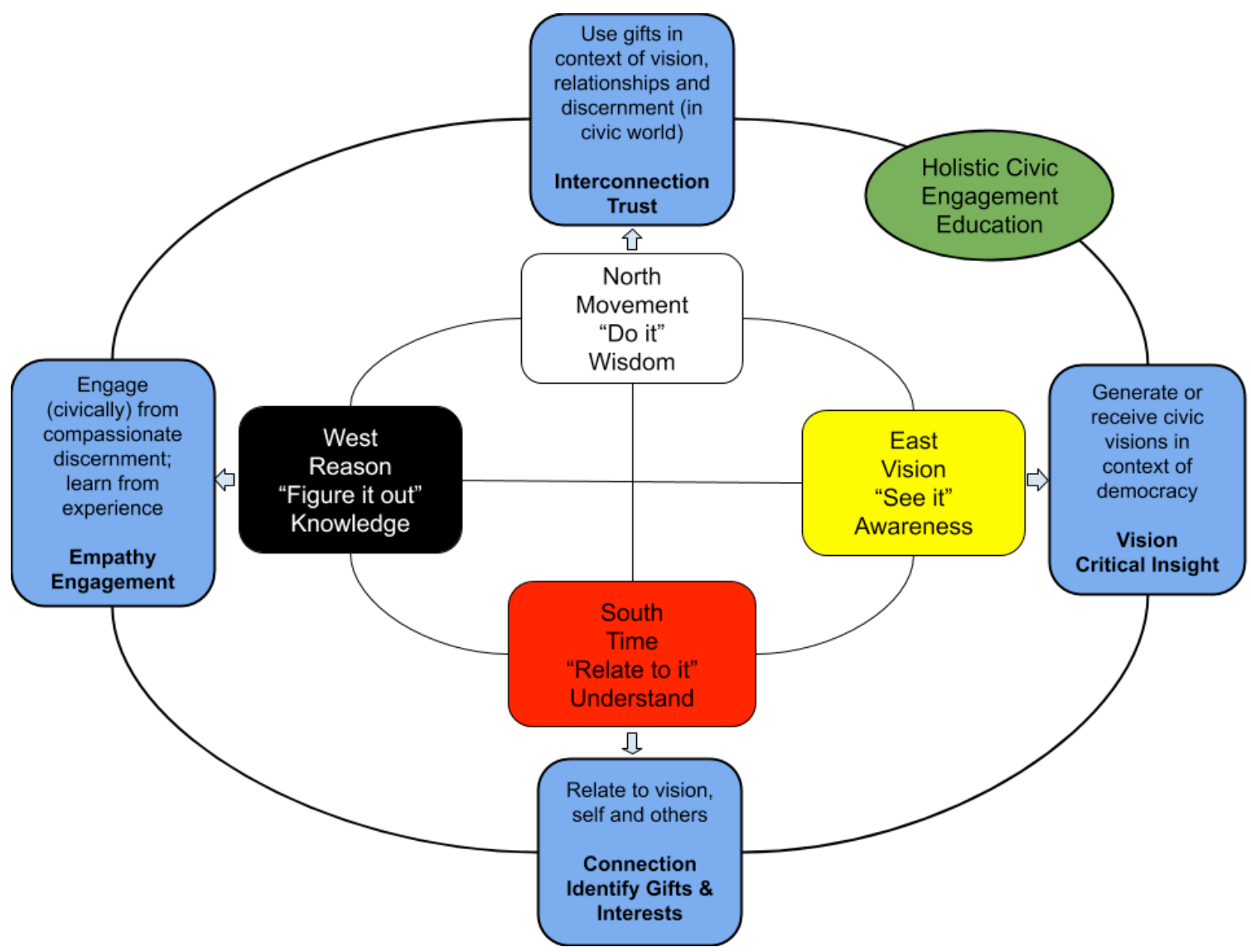




\section{Model of Holistic Civic Engagement Education}

The Model was developed based on (1) an application of Bell's (2014) Wheel to civic engagement education, and (2) a synthesis of the literature applying to holistic civic engagement (Table 2.2). Once I developed the capacities based on the Wheel, I consulted the relevant literature to propose the competencies that could enable students to express and live those capacities. Table 2.3 summarizes the literature and concepts that inform the eight competencies proposed in the Model. Below this, I describe the Model's components in more detail.

Table 2.3: Development of the Competencies from Relevant Literature

\begin{tabular}{|c|c|c|}
\hline $\begin{array}{l}\text { Direction and } \\
\text { Capacity }\end{array}$ & Competencies & Concepts from Literature \\
\hline \multirow[t]{2}{*}{$\begin{array}{l}\text { East } \\
\text { Generate or } \\
\text { receive civic } \\
\text { visions in } \\
\text { context of } \\
\text { democracy }\end{array}$} & Vision & $\begin{array}{l}\text { - Orienting engagement toward vision rather than away } \\
\text { from an undesired situation is considered a potent and } \\
\text { sustainable orientation to engagement (Merculieff, 2015) } \\
\text { - Shared visions held by groups are important to } \\
\text { engagement (organizational and civic) in that it drives, } \\
\text { inspires, and sustains it (Edwards and Post, 2008; Senge, } \\
\text { 1990). } \\
\text { "The first step in making change is to imagine new } \\
\text { possibilities" (Ginwright, 2018, para. 5). } \\
\text { - Transformative education is needed in order to access } \\
\text { visions of more sustainable modes for the future } \\
\text { (Sustainability Education, e.g. Sterling, 2002). }\end{array}$ \\
\hline & Critical Insight & $\begin{array}{l}\text { - Critical insight is needed to see systemic patterns in } \\
\text { society contributing to disempowerment; this insight can } \\
\text { help support "political efficacy" and } \\
\text { "empowerment" (Community Psychology, Critical Social } \\
\text { Work, e.g. Christens, Winn \& Duke, 2016). } \\
\text { - Deliberative processes can lead to more legitimacy and } \\
\text { deliberation requires reason-giving, open-mindedness, } \\
\text { and an ability to integrate multiple truths (Deliberative } \\
\text { Democracy, e.g. Thomas \& Levine, 2011). }\end{array}$ \\
\hline
\end{tabular}




\begin{tabular}{|c|c|c|}
\hline $\begin{array}{l}\text { Direction and } \\
\text { Capacity }\end{array}$ & Competencies & Concepts from Literature \\
\hline \multirow[t]{2}{*}{$\begin{array}{l}\text { South } \\
\text { Relate to } \\
\text { vision, self } \\
\text { and others }\end{array}$} & Connection & $\begin{array}{l}\text { - Connection to others is understood as an embodied act } \\
\text { (Lin, Oxford, \& Brantmeier, 2013). } \\
\text { - Connecting and relating to others helps build community } \\
\text { and a sense of belonging (Block, 2008). } \\
\text { - Ties between community members can ultimately help } \\
\text { strengthen democratic institutions (Putnam, 1994). } \\
\text { - Relational skills such as interpersonal communication, } \\
\text { ability to build trust, communication, and political } \\
\text { sensitivity are essential (New Public Governance, e.g. } \\
\text { Lazenby, 2014). }\end{array}$ \\
\hline & $\begin{array}{l}\text { Identify Gifts } \\
\& \text { Interests }\end{array}$ & $\begin{array}{l}\text { - Learning about one's unique gifts is connected to the } \\
\text { physical dimension because it is an expression of our } \\
\text { differentiated individuality (Armstrong, 1996). } \\
\text { - Personal and political work are both necessary and } \\
\text { investing in one area feeds the other (Spiritual Activism, } \\
\text { e.g. Anzaldúa, 1987). }\end{array}$ \\
\hline \multirow[t]{2}{*}{$\begin{array}{l}\text { West } \\
\text { Engage } \\
\text { (civically) } \\
\text { from } \\
\text { compassionate } \\
\text { discernment; } \\
\text { learn from } \\
\text { experience }\end{array}$} & Empathy & $\begin{array}{l}\text { - Empathetic noticing is an important first step in creating } \\
\text { change (Nonviolent Communication, Rosenberg, 2003). } \\
\text { - An empathetic understanding of apathy allows us to see } \\
\text { disengagement as a result of obstruction or suffering, } \\
\text { rather than merely a shortcoming (Ecopsychology, e.g. } \\
\text { Lertzman, 2015). } \\
\text { - Given the role of emotions in political thinking, it is } \\
\text { important to learn empathetic analysis for emotional } \\
\text { awareness as part of an education (Immordino-Yang \& } \\
\text { Damasio, 2007). } \\
\text { Empathy is seen as politically strategic. It creates space } \\
\text { for the others to change (Spiritual Activism, e.g. Edwards } \\
\text { \& Post, 2008). }\end{array}$ \\
\hline & Engagement & $\begin{array}{l}\text { - Civic engagement is key to strengthening institutions and } \\
\text { sustaining democracy (Civic republicanism, e.g. Sandel, } \\
1996 \text { and Putnam, 1993). } \\
\text { - Healing centered engagement is asset driven and focuses } \\
\text { on the well-being we want, rather than symptoms we } \\
\text { want to suppress, taking a salutogenic approach } \\
\text { (Ginwright, 2018). } \\
\text { - Skillful confrontations of (engaging with) personal } \\
\text { traumas can help reframe community narratives and } \\
\text { strengthen a sense of self-determination (Trauma } \\
\text { informed pedagogy, e.g. Falkenburger, Arena, \& Wolin, } \\
\text { 2018). }\end{array}$ \\
\hline
\end{tabular}




\begin{tabular}{|c|c|c|}
\hline $\begin{array}{c}\text { Direction and } \\
\text { Capacity }\end{array}$ & Competencies & Concepts from Literature \\
\hline \multirow[t]{2}{*}{$\begin{array}{l}\text { North } \\
\text { Use gifts in } \\
\text { context of } \\
\text { vision, } \\
\text { relationships } \\
\text { and } \\
\text { discernment } \\
\text { (in civic } \\
\text { world) }\end{array}$} & Interconnection & $\begin{array}{l}\text { - Interconnection informs the perspective that everyone } \\
\text { matters (Sturm, Metz \& Oxford, 2013) } \\
\text { - Cultivating interconnectedness makes us more capable of } \\
\text { hearing and making sense of information emerging from } \\
\text { beyond the individual (Armstrong, 1996). } \\
\text { - Civic learning involves, most importantly, how to work } \\
\text { as a community to address community concerns (Public } \\
\text { Administration, e.g. Ehrlich, 2009). } \\
\text { - Mutual dependence can open the way for a new mode of } \\
\text { thinking-a mode in which root level cultural } \\
\text { assumptions can be set aside long enough to envision and } \\
\text { commit to alternatives (Contemplative Education, e.g. } \\
\text { Wals \& Corcoran, 2012) }\end{array}$ \\
\hline & Trust & $\begin{array}{l}\text { Trust allows one to step into a larger process without } \\
\text { needing to know the outcome (Edwards and Post, 2008). } \\
\text { - Short-term gains and losses should not be the sole focus; } \\
\text { this is important to sustain commitment (Spiritual } \\
\text { Activism, e.g. Anzaldúa, 1987). } \\
\text { - Civic work is a journey; it requires trust in a large-scale } \\
\text { process rather than a focus on an end goal (Visionary } \\
\text { Pragmatism, e.g. Collins, 1998). }\end{array}$ \\
\hline
\end{tabular}

\section{HCEE Model Components}

East: Vision, seeing and awareness. Capacity: Generate or receive civic visions in context of democracy. Competencies: Critical Insight and Vision.

The East is the direction of vision and awareness. Applied to the civic world, a capacity for vision involves holding several scaled visions at once and being able to navigate between them. These visions include one's personal vision (including vision for a lifetime, visions for the next five years, etc.), the visions of organizations and institutions one functions within, and larger-scale visions that stem from democratic values such as equity and justice. For civic engagement education, one particularly relevant aspect of vision is working with American democratic values such as equality, 
freedom, justice and participation. Part of civic engagement is holding onto these values while navigating the current realities of institutions.

For this reason, the two competencies that map to the East are Vision and Critical Insight. To engage civically, one ideally holds a personal vision for participation, a group vision held by a collective effort, as well as a sense of how the endeavor serves democratic outcomes. Critical Insight is a habit of mind that is inquisitive, piercing and engaged. It looks for evidence, makes comparisons, and uses skepticism as a tool to refine logic. Critical insight is key to civic engagement because the ability to examine social realities and generate explanatory insights is essential for taking directed and informed action. Analyzing power dynamics is part of critical insight. When citizens see larger patterns in society that may have contributed to their feeling of disempowerment, this can transform into a political challenge with potential for redress, rather than an individual deficiency that cannot be changed (hooks, 1994). Finally, Critical Insight can tolerate - and is unafraid of discovering — divergence between a reality and an ideal. It is important that it is paired with Vision, which can allow students to experience this as a divergence they can work to bridge, not a chasm into which to fall.

Vision is important as well in that orienting engagement toward vision rather than away from an undesired situation is considered a potent and sustainable orientation to engagement (Merculieff, personal communication, April 17, 2015). Armstrong (1996) refers to the mental self, when using its full potential, as "directed by the ignited spark" (p. 464). This implies a perspective that the spark exists, and the mind follows its instigation. Vision, especially shared visions held by groups, is important to civic 
engagement in that it drives, inspires, and sustains it (Edwards and Post, 2008; Senge, 1990).

South: Relating to understand. Capacity: Relate to vision, self and others. Competencies: Connection and Identifying Gifts \& Interests

In the South of Bell's Wheel lie the qualities of relating and taking time to understand. This is distinct from the process in the West, which has to do with building understanding as well, but through reason rather than relationship. Applied to civic life, these qualities could be expressed as a desire to connect and relate, to see oneself and others through an asset-based lens that asks, "What are this person's gifts?" Part of this is turning to oneself to build awareness of one's strengths and interests, so that work in the civic world is more meaningful. Armstrong states that the physical self is connected to all the other selves and contains us as differentiated individuals. Learning about one's unique gifts is connected to the physical dimension because it is an expression of our differentiated individuality (Armstrong, 1996).

The competency of Connection lies in the South as well. It refers to the ability to feel an embodied sense of connection (Batacharya and Wong, 2018; Featherstone, 2013). Menakem (2017) discusses the importance of working with the physical body as a site for wellness, connection and agency. Miller (2007) and other holistic education scholars argue for the importance of including the physical body in course planning, even in higher education (Burns, 2015; Yeager \& Howle, 2013). Connection to others is also understood as an embodied act (Lin, Oxford, \& Brantmeier, 2013). In civic life, relating to others helps build community and a sense of belonging (Block, 2008). Ties between 
community members can also help sustain civic endeavors and, ultimately, strengthen democratic institutions (Putnam, 1994). Ideally, students can come to both value social connection and be more tolerant of the discomfort of relating to others in public spaces. West: Using reason, "figuring it out" through experience. Capacity: Engage (civically) from compassionate discernment; learn from experience. Competencies: Empathy, Engagement.

In the West lies the capacity for reason, engaging and puzzling through, and growing in discernment and wisdom. Applied to civic engagement, this would be expressed as a capacity to step into active civic life, grow through experience and exposure, and become more discerning and compassionate in evaluating public issues. Though this stage involves active engagement, it is not yet the North stage of wise action; in the West there is still "figuring it out." The educational capacity here is compassionate discernment. As part of this stage, students engage both publicly and personally. Publicly, they investigate civic areas of interest, participating in civic life through structured community-based learning. Personally, they engage with their own process, learning to be discerning about what they are feeling and needing, and what is motivating their actions.

The competencies underlying this are empathy and engagement. Empathy is the ability to imagine others' experiences, especially their emotional experience (Rosenberg, 1999). This is paired with Engagement, which refers here to an individual's ability to pay attention, be curious and interactive, and to care. Engagement without empathy has the potential to too strongly favor one's own perspective. Empathy without engagement misses the opportunity that comes to act on wisdom gained by knowledge of others. Palmer (2011) writes that "When all that we understand of self and world comes together 
in the center place called the heart, we are more likely to find the courage to act humanely on what we know" (p. 6). These two competencies link closely to this statement; compassionate understanding and discernment fuel caring engagement. North: Wise action to create change. Capacity: Use gifts in context of vision, relationships, and discernment (in civic world). Competencies: Interconnection, Trust.

In the North lies the important stage of taking wise action. Bell's (2014) Wheel refers to "Movement" in the North. I interpret this as willingness and desire to make change, to instigate movement in the larger system that connects individual, community and society. Importantly, in the context of the Wheel, this movement and action are informed by wisdom. Here, wisdom is the result of a progression of awareness (gained through seeing), understanding (gained through relating), and knowledge (gained through engaging).

The competencies here are Interconnection and Trust. Though these do not seem like action-oriented competencies, they are important as a frame of understanding from which to take action. Trust allows one to step into a larger process without needing to know the outcome (Edwards and Post, 2008). Trust is needed for the capacity to feel oneself as part of civic community, and part of large-scale social movements that span space and time. Civic leaders refer to the importance of trusting in the process of justice —implying that short-term gains and losses should not be the sole focus - and that this is important to sustain commitment (Anzaldúa, 1980). Trust could also be possibly also be called "hope" (Loeb, 2017; Orr, 2011). 
Interconnection gives weight to seemingly small actions, and the perspective that everyone matters informs actions (Sturm, Metz \& Oxford, 2013). For Armstrong (1996) and others, connection to nature is literal, and the spiritual self is capable of hearing and making sense of information emerging from beyond the individual. In the civic realm, interconnection serves as fuel for commitment to the public good.

Part of the intent of this Model is that it could be drawn upon for curriculum design in multiple ways, and at multiple levels. Instructors could incorporate one capacity into a course, for instance. If the Model functions as intended, developing that one capacity would implicitly include, and potentially develop, the other three capacities. Similarly, an instructor could include one of the competencies in course design with the same (hypothesized) effect. The more capacities and competencies included in a design, the more mutual reinforcement could likely occur during the learning process. It seems unlikely that all eight competencies could be emphasized in a single course. It does seem plausible, however, that in designing academic programs, all eight could be developed strategically across the program's courses.

\section{Teaching from the Model: Re-engagement Tool}

The Model is intended as a contribution to the field, a proposed mapping of holistic civic engagement education for discussion and further consideration. In order to begin the (multi-stage) process of investigating the helpfulness of the Model, we need to develop a curricular strategy based upon it. This strategy is the re-engagement tool. This section describes the tool - the considerations for design, and its components.

\section{Design considerations}


Rather than enhance content delivery, which is already thoroughly addressed in Education literature, this Model and tool are intended to help instructors teach students to "become" and "live" the content by assisting them in locating inactive assets within themselves and reactivating those assets. The insight (East), empathy (West), connection (South) and wisdom (North) are all drawn upon in a process of reactivation. Because we are focused on civic engagement learning, this reactivation is directed toward civic reengagement.

Drawing from this review of the literature, we take as premises that (1) students have gifts to contribute and they inherently care about the civic world, (2) that they have visions and values that inspire them, and (3) that past experiences can contribute to disengaged behavior, and could be ameliorated in a manner appropriate to higher education as part of encouraging civic engagement. The essence of the curricular strategy developed for this context — the re-engagement tool—is to guide students through the South, West and East stages, with the aim of allowing them to arrive in the North with enhanced capacity for wise civic action. Figure 2.6 shows how the Tool guides students through the South, West and East directions. 
Figure 2.6: Re-engagement Tool for Holistic Civic Engagement Education

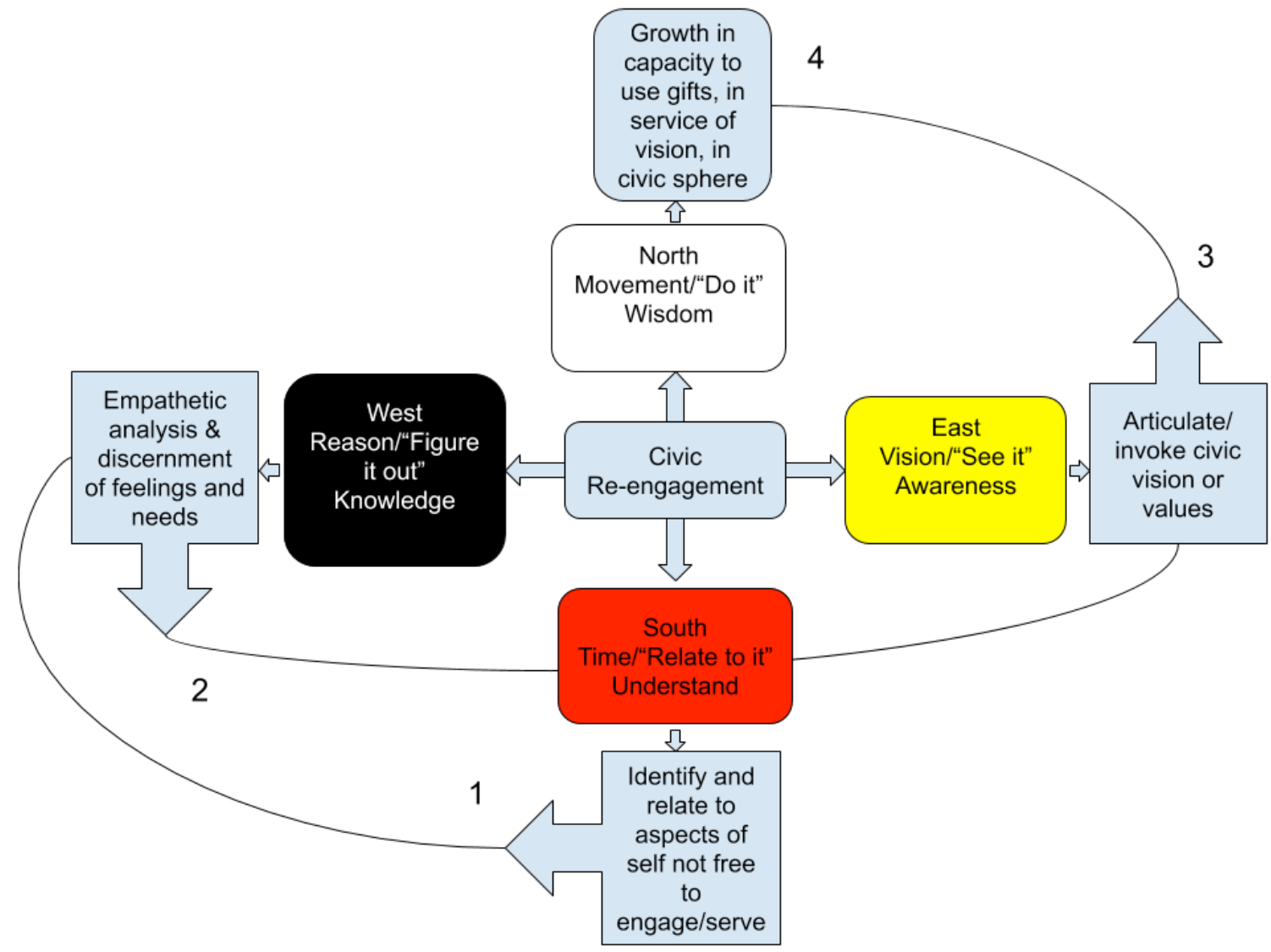

The tool prompts students to move through four stages, and also through the four holistic dimensions. The holistic lens sees civic engagement expression (the "Do it" in the North) as connected to and dependent upon certain kinds of functioning on the other dimensions. In order to grow in our capacity to "Do it," we do not simply deploy more effort and hope for different results (though sometimes more effort is indeed all that is needed). Instead, holistic and transformative learning indicates that we engage the other dimensions. The tool prompts a particular approach that involves first forging a connection to oneself and a past behavior (physical level), then bringing empathy to that 
"self" (emotional level), and then invoking a vision (spiritual level), to allow more capacity to serve in civic life (mental level).

\section{Working with the Stages of the Tool}

1. Identify and relate to aspects of the self not free to engage/serve

This first stage is about creating awareness. Specifically, it draws on the understanding in contemplative education that compassionate noticing is an important first step in creating change (Lin, Oxford \& Brantmeier, 2013). In this kind of noticing, students are prompted to maintain a nonjudgmental stance (Rosenberg, 2002). They cultivate an ability to function in two ways simultaneously—as compassionate observer and recipient of compassionate noticing (Neff, 2011). This dual awareness is encouraged in the curriculum through assignment prompts, instructor presentation of the assignment, and in-class activities to set the stage. The writing assignment for stage one then asks students to describe experiences of engagement and disengagement.

2. Empathetic analysis and discernment of feelings and needs

At stage two of the process students are taught to draw on the tool of Nonviolent Communication (Rosenberg, 2003). Nonviolent Communication has been widely adopted in community settings and in some academic settings as well (e.g. Chubbuck \& Zembylas, 2011). The portion of the practice that is relevant here is guiding students through identifying feelings and needs that emerged from their experience. Nonviolent Communication materials provide a rationale for the process and lists of sample feelings and needs. Through readings, video, and in-class practice, students develop a basic facility with the practice. Their writing assignment guides them to select a key experience 
of disengagement, and, maintaining the stance of compassionate witness, to identify feelings and needs that were present for that "self" experiencing the disengagement. They might also note whether they felt any of their gifts or interests became stagnant or lost as part of the experience.

3. Articulate/invoke civic vision or values

Stage three of the process involves articulating personal visions or values. In the writing assignment, the students invoke their values about civic life or public service specifically in the context of their disengagement. This stage of the process is intended to function as an opportunity to shift their relationship to that experience. While they acknowledge the difficulty of the experience, they also note that their values indicate a need to re-engage, to serve, and to share their gifts in the public sphere.

4. Growth in capacity to use gifts, in service of vision, in civic sphere

Stage four is not part of the writing sequence; rather, the aim of the narratives is to help students grow in their capacity to use their gifts in civic life. Ideally, students "arrive" in the North (an arrival which is meant to happen many times throughout one's life), having moved through the other three directions to facilitate holistic civic engagement development.

\section{Personal narrative as vehicle for re-engagement}

Narrative writing is seen as a valuable process as it can help writers make sense of their experiences and arrive at new insights (Clark \& Rossiter, 2008). Anzaldúa (1987) wrote that for her, writing was "an endless cycle of making it worse, making it better, but always making meaning out of the experience, whatever it may be" (73). 
Autobiographical writing in higher education courses is thought to enable students to bring a sense of order to their lives, bring attention to key moments of decisiveness, help process difficult events, and elicit insight into personal development (Karpiak, 2000). Hopkins (1994) wrote that, "Our narratives are the means through which we imagine ourselves into the persons we become" (p. xvii). This "imagining ourselves" through personal narrative is considered transformative (Mezirow, 1990) and has been called "restorying" (Randall, 1996). Restorying refers to "gaining a more critical and empowered perspective on one's life through telling and interpreting one's self story" (Rossiter, 2002, p. 4). In restorying, the writer sees a new perspective and can claim more agency as the author of their life. Most importantly, this can open students to new narratives about themselves - their stories lead them "beyond" themselves (Rossiter, 2002).

The application of narrative writing to civic engagement education is promising, but as De Groot (2018) points out, it is under-explored. If we embrace the "autobiographical dimension of learning" (Rossiter, 2002, p. 5), then the autobiographical dimension of civic learning could include the narratives that citizens hold about their efficacy and capacity. These narratives about how open the civic world is to each of us, and how warmly we feel invited into the public sphere, are potentially quite significant in shaping behavior. Working with university students to examine and rewrite their narratives - especially those narratives that include a conception of themselves as disengaged —could have important impact. In this study, the intent of teaching the tool through narrative essay was to help students grapple with their past disengagement and 
open to new, more empowered narratives about themselves and their civic agency. The specific writing prompts were tailored to the content of each course in the study, which is discussed in Chapter Three.

\section{Part II Conclusion}

Through using the re-engagement tool in civic engagement education, the intent is to facilitate holistic transformative learning and allow students' capacity for engagement to emerge more fully. As Elias (1997) wrote, "transformative learning is facilitated through consciously directed processes such as appreciatively accessing and receiving the symbolic contents of the unconscious and critically analyzing underlying premises" (p.

3). The re-engagement tool guides students through a "consciously directed process," that brings self-compassion and empathetic analysis to a past source of disengagement. In bringing a more empowered awareness that focuses on a positive vision of what is possible, students have the opportunity to critically re-examine the "underlying premises" of their disengagement. There is the possibility for them to emerge from the narrative writing process with a sense of an enhanced access to their own engagement potential.

In this chapter I reviewed and synthesized the literature relating to holistic civic engagement education for undergraduates. Based on the key findings from this review, I proposed a map — the Model—for what might comprise holistic civic engagement education. This map included capacities and competencies arranged around a Medicine Wheel shared by Bell (2014). As a transformative teaching strategy to build these competencies and capacities, I proposed a trajectory for a narrative writing sequence that could take students through a process of encountering, and coming to a more empowered 
relationship with, past experiences of disengagement. This process was called the reengagement tool. The following chapter describes how I incorporated the tool into two thematically-related undergraduate courses. It discusses the design of the study that would shed light on the impacts of doing this. 


\section{Chapter Three: Study Design}

Chapter Two proposed a holistic model for undergraduate civic engagement education. It presented capacities and competencies to be taught, and proposed a curricular strategy: the re-engagement tool. It suggested that personal narrative assignments could be particularly useful as a means to teach the re-engagement process in curricula and teach overlooked competencies. To assess the potential of the reengagement tool taught through personal narrative writing to impact students' capacity for civic engagement, this study poses the question: How does writing a sequence of engagement/service personal narratives impact undergraduates' capacity for holistic civic engagement? In order to address this question, I also asked, What learning did students demonstrate in relation to holistic civic engagement capacities and competencies? This chapter contains four primary sections. First, it describes the research approach and its rationale given the research question. Second, it lays out the design of the study, describing the application of the Holistic Civic Engagement model and the reengagement tool to two college courses. Third, it discusses the strategies implemented to collect data. Finally, it lays out the process used to analyze this data.

\section{Research Methods}

Appropriate research methods for this study needed to yield information about how and where the new model has been successful, where it needs development and revision, and what must be considered for others who apply it. This suggested the usefulness of research methods that generate thick data, as this could allow for analysis of students' understanding of causal mechanisms, the implicit connections between their 
beliefs and their feelings, and their interpretations and assumptions. Other considerations for selecting a research strategy included: the goal of generating a valid study while also revising and responding to classroom factors throughout, the goal of practitioner development, and the aim of minimizing bias even as the study took a normative stance and sought value-based outcomes such as active civic republican participation. These considerations let to the selection of Action Research as an appropriate strategy. Research Strategy: Action Research

Action research orients toward thick and robust data collection, drawing on multiple means, to understand students' experiences (Cresswell \& Plano Clark, 2011). It acknowledges the role of the researcher as practitioner with experience in the research area. The body of research about this approach can provide guidelines for a valid process for iterative and flexible implementation of the intervention/curriculum, and an accounting for larger social justice goals in conducting the study (Greenwood and Levin, 2007). Action research bounds episodes of research based on the context of the study (Argyris and Schön, 1991). I bounded my study with the term length of the university courses in which I implemented the curriculum.

Used widely in Education and occasionally in organizational research in Public Administration, action research has been developed to inform research projects that seek to understand the effects on people of implementing new practices (Cunningham \& Leighninger, 2010). It gives special weight to the practitioner's reflection and adjustment during the study (Argyris and Schön, 1991). Reflections and adjustments are seen as the result of intelligent observation based in experience, are recorded, and become part of the 
larger understanding of how implementations of the new practices lead to varying outcomes. Action research emphasizes research questions emerging from practitioner/ researcher puzzles and problems. It builds theories "within the practice context itself," and "tests them there through intervention experiments...which bear the double burden of testing hypotheses and effecting some (putatively) desired change in the situation" (Argyris and Schön, 1991, p. 86). In this way, action research is both research and problem solving tied to pressing concerns and grounded in particular social settings (McKernan, 1998).

Much of what motivates action research studies is the practitioner's desire to improve the integrity and justice of their practice (Kemmis and McTaggart, 1987). This approach acknowledges that more deeply understanding one's rationale or philosophy of practice is an important part of improving that practice (McCutchen and Jung, 1990). As the practitioner implements a new approach, she reflects not only on its effects, but also on the underlying assumptions that shaped its development. This awareness creates room for changes that may be needed, but are difficult to discern as they may be based in new paradigms or mental models.

Some argue that there is a key collaborative component to action research — that the critically examined action of a group's members is essential (Kemmis and McTaggart, 1987). Action research on civic education would ask students to reflect deeply as part of the learning process; this also serves the larger intent of collectively deepening critical awareness and creating space for social change. Most agree that action research builds knowledge for the express purpose of capacity building and democratic social change 
(Greenwood and Levin, 2006). This ethic of action research pushes one to continually see students as active participants in their education, which will also give them an experience of being seen as active participants in public problem solving. Finally, action research views the teaching process itself contains opportunity for faculty development (Kemmis and McTaggart, 1988).

\section{Implementing action research for this study}

The aim here was to understand how a different approach to practice affected student learning and their apparent capacity as citizens. Action research was a useful methodology because the research question was grounded in a particular context-civic learning in higher education - and it came out of a desire to bring deeper awareness to practice in a way that could extend to others' practice. The emphasis on adjustment and reflection allowed me to improve the approach, which was particularly helpful in the early stages of implementation. In my case, developing the theory presented here is a longer-term career goal, so the emphasis on development was significant both for me and future students. This also provided the structure for value-driven and self-reflective research to be conducted in a transparent and valid way. I had explicit aims as researcher to promote democratic engagement and social justice. The action research process encouraged me to be transparent and reflective about these values.

Pragmatic paradigm

I situated this research within a pragmatic paradigm, in which less focus is placed upon building generalizable theory than upon the transferability of knowledge (Morgan, 2014). In implementing the study, the questions were intended to assess how transferable 
(useful) this approach could be to others. This was distinct from asking if most students generally would benefit. Pragmatism is not highly concerned with causality—while the correlation of certain variables is important because it helps improve practice, this paradigm acknowledges that causality can be difficult to prove. In seeking transferability rather than generalizability, the research process was intended to reveal insights about the model's impacts and usability. The pragmatic paradigm also indicates that research methods are selected based on a pragmatic consideration of the research goals. In this case, to generate thick data that could shed light on students' thinking and learning processes, a qualitative approach best matched the study goals.

\section{Qualitative Approach}

It was important to place students' words at the center of the investigation and help respond to the "How?" at the center of the research question. Qualitative data analysis can be defined as "the classification and interpretation of linguistic material to make statements about implicit and explicit dimensions and structures of meaningmaking in the material and what is represented in it" (Flick, 2014, p. 5). This project seeks to understand how a curricular strategy impacts students' capacity. Qualitative analysis is a useful approach here because the data takes the form of student writing ("linguistic material"), and data analysis ("classification and interpretation") will seek to shed light on student learning ("make statements" about "dimensions of meaningmaking"). Furthermore, a qualitative approach is indicated when a researcher strives to draw upon multiple sources of evidence (Yin, 2011). This study draws on multiple written assignments to inform questions about students' process of meaning-making. 
Going forward, quantitative analysis may be helpful in the process of studying holistic civic engagement education. Quantitative inquiry could shed light on the degree to which the learning outcomes were met and help identify important patterns in how the Model impacted students. However, at this stage of initial implementation of the Model and tool, generating insight into the nature of individual students' responses is most useful. Understanding how students make meaning in the context of the curriculum can best inform its revision. We apply a qualitative approach because we seek "in-depth, individualized, and contextually sensitive understanding" (Patton, 2015, p. 7). The following section discusses the context and design of this research study. After describing the research context, it lays out how the re-engagement tool and HCEE Model were applied to two course curricula in order to investigate their impacts on student learning.

\section{Study Design}

The study was conducted in the context of two undergraduate courses during Fall 2018 and Spring 2019 at Portland State University. The courses were offerings from the Public Administration department's Civic Leadership Minor. Though relatively few students earn the minor degree, the 300-level classes attract students from across the university as they meet breadth requirements (University Studies Clusters). The classes in the Minor are intended to serve as both practical and theoretical grounding in democratic participation; the Minor "prepares students to be responsibly engaged, social justice oriented citizens and community leaders" ("Undergraduate Civic Leadership Minor," para. 1). In terms of practical skills, the courses are designed to teach students to: Build consensus for public action, facilitate groups and meetings, engage in social organizing, 
collaborate effectively in diverse contexts, support democratic decision-making, communicate effectively, and conduct community-engaged research.

In a given term, approximately 150 students are enrolled in Minor courses. The majority of these students take the courses online. Since beginning to offer online courses several years ago, the Department has seen demand for them increase. Approximately three years ago, overall interest in the courses began to decline. Though the Dean of the College of Urban and Public Affairs, in which the Minor is housed, undertook a study to understand this decline, the Minor has not fully regained its popularity. Some courses that were offered both in-person and online have begun to be offered only online in some terms. The two courses in the study were two of the three most popular courses in the Civic Leadership Minor. They were assigned to me so I could implement the study in well-enrolled 300-level courses, but Department staffing requirements were the key factor in determining exactly which courses would be the setting for the study.

A diverse public urban university is an important context for this research. Public universities enroll approximately 15 million students, about three times the number enrolled at private institutions (National Center for Education Statistics, 2019). Upwards of 80 percent of the U.S. population lives in urban areas and this percentage continues to grow (University of Michigan Center for Sustainable Systems, 2019). Given these demographic factors, it is important to develop strategies for teaching civic engagement at urban public universities. The following section describes the specific courses that were the context for the study. 


\section{Course One: Introduction to Civic Engagement}

The first of the two courses in the study was Public Administration 311U:

Introduction to Civic Engagement, which is officially described in the following terms in the Course Catalog:

This course examines the concept of civic engagement by exploring how relationships are strengthened and communication is nurtured among members of society, and how this contributes to a civic identity that promotes socially conscious thought and action. The course will examine the values, skills and actions that contribute to a sense of civic identity through assigned readings, lectures, discussions, group activities, and self-reflection. A central goal of this course is to help students prepare for a lifetime of responsible citizenship and civic engagement. This course includes a community-based learning project.

The syllabus of Introduction to Civic Engagement was designed to cover key introductory themes: the historic importance of civic association in the United States, trends in civic association over time, power and privilege in civic engagement, participatory and deliberative democracy, social movements and civic engagement, and civic leadership and personal engagement choice. I have taught this course ten times at PSU. Though I redesigned it each time I taught it, the HCE lens resulted in significant revisions, especially the addition of a sequence of three writing assignments intended to build HCE competencies. Appendix A contains the complete course syllabus.

Students in this course were predominantly social science majors, but we also had Business, Biology and Chemistry majors. There were 19 students in the course, which 
was taught during the Fall 2018 term on Tuesdays and Thursdays at noon. Table 3.1 summarizes the demographics of the 13 students who opted to participate in the study. Course Two: Fundamentals of Public Service

The second of the two courses in the study was PA 313U: Fundamentals of Public Service. Unlike Introduction to Civic Engagement, this course is a specific requirement for students outside the Civic Leadership Minor, namely Political Science majors concentrating in Public Service. Fundamentals of Public Service is described to students with the following:

Exploration of how public service informs the roles of public/nonprofit organizations in social change. Introduction to conceptual public service frameworks and exploration of the historical dimensions, underlying values and external forces that shape contemporary public service. Ways for community members to influence public policy through civic engagement are addressed.

Fundamentals of Public Service is organized around a conceptual framework known as "New Public Service." Laid out in the course text, New Public Service frames public servants as "professional citizens" who elicit public input rather than implementing their own agenda (Denhardt \& Denhardt, 2015). This conception is contrasted with Old Public Administration, a hierarchical mode of public leadership, and New Public Management, which adopts market-based values such as efficiency and competition to lead the public sector. Spring 2019 when I implemented the study was the first time I had taught this course. I revised the syllabus significantly, though I maintained the text and the community based learning assignment. 
Unlike Introduction to Civic Engagement, students in this course were not dipping their toes into something new, but rather taking a course to complement their existing interest in public service. As Table 3.2 shows, their majors were largely in social work and other service-related fields. All the students had substantial service experience upon entering the class. Some of them had worked for elected officials, others in the nonprofit or education fields, and a substantial number planned jobs in public service.

Fundamentals of Public Service was a fully online course. This was not part of my study design, but registration numbers required that I switch from teaching the inperson version — which was cancelled — about four weeks before the term started. I had taught online courses on five other occasions and been trained by PSU's Office of Academic Innovation in how to encourage engagement, community, and overall learning through the online vehicle. This trend toward student demand for online courses does require us to ask the question of how to teach well in an online format. This study engages that question indirectly, but it is not intended as a study of online learning and teaching.

Applying the Model and Re-engagement Tool to the Study Courses

The Model and re-engagement tool were applied to these two courses through personal narrative assignments. The components of the tool were embedded into the essay prompts, guiding students through use of the tool. Appendices $\mathrm{G}$ and $\mathrm{H}$ contain the full assignment descriptions. The tool, it should be noted, is the focus of the implementation; the Model is implicitly implemented by using the tool. 


\section{Course One: Core Narrative Sequence}

Course One, Introduction to Civic Engagement, serves in the Minor curriculum as an introduction to the practice and importance of civic engagement. The sequence of narratives was designed to guide students (1) through identifying internal and felt challenges to engaging and using their gifts, (2) to initiate some reconciliation in relation to past disengagement, where there was a sense of losing access to a gift, and (3) to reengage with a gift and commit anew to using that gift in service of a larger vision.

\section{Narrative Assignment Part One}

This first paper (see Appendix B) was primarily intended to bring awareness to the personal causes of disengagement in order to begin the process of addressing those causes and increasing the potential for engagement. In order to deepen learning about reengagement, students needed to thoughtfully identify an instance of disengagement. This would allow them to practice applying the re-engagement tool to a significant example. It was important to allow time and build trust in order for students to feel comfortable accessing and working with a potentially-challenging instance of disengagement.

The assignment also had two secondary goals: It was intended to help students increase their awareness around the factors of their own engagement so they could more purposefully shape future engaging contexts for themselves. Also, the paper was designed to help create a foundation for understanding theories of civic engagement by eliciting their reflection on the factors that motivate engagement. The assignment description (Appendix B) was given as a handout in class, published on the course website, and was accompanied by an in-class exercise. 
The in-class component of this assignment took place in Week Two. I created a visual activity in which students brainstormed engaging and disengaging experiences, the areas of their life (e.g. family or school) in which they had the experiences, and the beliefs (about self and world) that they may have learned and carried forward after the experience. "Engaging" experiences were explained to be experiences in which students felt their innate motivation activated and their care and interest peaked. "Disengaging" experiences were framed as experiences in which students felt demotivated, disinterested, or "shut down." I modeled this activity on the board with a suggested visual organizational structure, we discussed examples together, and then students completed the activity independently while we listened to music chosen by a volunteer. Students were then to draw on this exercise to choose three experiences on which to elaborate in their papers.

The essay component of the assignment elicited two to three pages of writing describing one engaging experience and two disengaging experiences. Prompts asked students to relay the context of the experiences, the personal values upon which they were acting or attempting to act, and their interpretation of what made the experience engaging or disengaging. They were asked to conclude by briefly considering how these experiences might have affected their civic lives.

Narrative Assignment Part Two

Part two of the narrative assignment sequence was due in Week Seven. This essay (see Appendix C) asked students to select one of the disengaging experiences from Part One and bring contextual understanding and empathetic analysis to that experience. The 
assignment took the form of a letter written from the current self to the earlier self who was in the midst of the disengagement. The letters had three parts: First, the students responded empathetically to the earlier self using the framework of Nonviolent Communication (Rosenberg, 2002). Second, the students built on their empathetic understanding of the situation to choose readings and other class activities with which to respond to the earlier self's feeling of disengagement. Third, they directly requested that the earlier self re-engage in service of a vision that was meaningful to both "selves." The overall goal of this was to teach students a practice they could use to make conscious decisions about civic engagement based on their values, rather than unconscious decisions based on past struggles.

This was the most key single learning activity in this HCE course. Based on the components of the HCEE Model, it walks students through the stages of the reengagement tool. Though the assignment treats disengagement generally, it is valuable for students to learn this strategy using whatever example is most pertinent for them at the time. In learning this skill, students would learn a process for addressing disengagement in their lives generally, both civic and personal. Because nearly all patterns of disengagement, even if they began in personal spheres, affect public engagement, it is relevant and necessary to teach re-engagement in all areas of students' lives.

The Nonviolent Communication (NVC) approach was an important aspect of this assignment. We had practiced applying the NVC lens in class and I had created a handout summarizing two key pieces: lists of emotions and universal needs. Based on students' 
application of the NVC framework in their papers, this appears to have been adequate preparation for this portion of the assignment. I should note that the NVC lens I was teaching in the course was a version of the full NVC process for conflict resolution. My emphasis was on examining challenging interactions in students' personal and civic lives. Though we practiced this tool by looking at personal relationships, ultimately I was teaching this version of NVC as a civic participation tool. In short, students learned to name the emotions and universal needs underlying an experience. They also practiced the skill of imagining others' experience, guessing the feelings and needs of those with whom they had a difficulty. The purpose was to both personally re-engage, and to interrupt the tendency to judge fellow citizens and dismiss their views.

I call this skill "empathetic analysis" to emphasize that the purpose goes beyond offering empathy. Rather, the aim is to offer empathy so that resolution can occur. Students are to empathize with their previous self to identify the causes of disengagement and facilitate re-engagement. Empathetic analysis works alongside critical analysis. By first identifying the underlying needs of a previous self, students can then respond with a critical analysis that helps the previous self to see systemic factors at play in their disengagement. These two analytic steps can help relieve students of feelings of blame or shame that they caused their own disengagement. Paradoxically, in critically naming systemic factors beyond their control, students can reclaim agency to act in accordance with their values despite external factors. 


\section{Narrative Assignment Part Three}

The purpose of this assignment was to give students an experience of connecting all four dimensions. Embedded in the final essay (see Appendix D) was another opportunity to practice the central re-engagement process taught through Part Two. Students were to use empathetic analysis, insight and vision to re-engage. Instead of reengaging a previous disengaged self, they were to attempt to identify and shift their relationship to patterns of disengagement. The assignment had four pieces that prompted students through this process. The first step was to articulate a "civic vision," something they felt was important to aspire to in the civic world, which could be as general as "a set of values" or "a kind of relating." The second step was to identify qualities of leadership that would be needed to move toward the vision. The third step was to name any personal challenges they would need to address in order to embody those leadership qualities. The final step was to apply empathetic analysis to those challenges. Ideally this last step would involve generating insight and a more skillful or empowered orientation to the challenges.

\section{Course Two: Core Narrative Sequence}

Course Two (Fundamentals of Public Service) introduces students to multiple perspectives on public service and the public sector. It asks students to consider public issues through several theoretical lenses, and to reflect on their own service goals. Like Course One, the core narrative sequence was designed to walk students through applying the re-engagement tool. Rather than working with the broad theme of engagement as in Course One, Course Two worked with a more specific form of engagement: service. The 
core narrative sequence for Course Two sought to guide students to bring insight to past experiences in which their own service expression was disrupted or limited. Through working through the tool, the intended outcome was re-engagement in the form of fuller potential for service. The sequence asked students to (1) reflect on their experiences of service and what service meant to them, (2) identify a past experience in which they did not feel free to serve as they wished to, and (3) discern their needs and apply empathetic analysis in order to reconcile with that experience and recommit to service. Having learned from Course One that the second narrative assignment appeared most central, I chose to assign only two narrative papers in Course Two.

\section{Narrative Assignment Part One}

The purpose of Part One of the narrative sequence (Appendix G) was to spur students' reflection on what "service" meant to them. As potential career public servants, it was important to ask them to consider how different approaches taken by professionals might impact citizens. Ideally, the assignment would also set the stage for students to ask what kinds of institutional and cultural factors could encourage people and organizations to systematically be "of service."

To support this reflection on service and its impacts, the narrative assignment drew upon the framework presented in the short article "Helping, Fixing, or Serving?" (Remen, 1999). This first-person essay, written by a physician who herself experienced serious illness, distinguished between "fixing," which we do when we see ourselves as separate and more competent, and "serving," in which we remain connected to the shared human experience and see others as whole. Remen (1999) writes, "When 
you fix, you see life as broken. When you serve, you see life as whole. Fixing and helping may be the work of the ego, and service the work of the soul" (p. 1). The intention of Part One was to teach students the conceptual distinction between "fixing" and "serving," and allow them to reflect on the distinct feelings that can arise from being the recipient of fixing versus serving

Specifically, the assignment description prompted students to reflect, without judgment, on one experience of feeling someone was "fixing" them and one experience of feeling someone was being of "service." Finally, they were asked to sum up their learning about fixing and serving and describe how it informed their conception of public service in the context of the course. In the assignment description, I emphasized honest reflection as an important tool in learning. I reiterated this and provided a rationale for reflective writing in the context of the course, through a video shared on the course site. Narrative Assignment Part Two

The second part of the narrative sequence (Appendix H) drew upon the students' consideration of the helping/fixing distinction, asking them to move from reflecting upon being fixed/served, to being in the fixing/serving role. Part Two walked students through the steps of the re-engagement tool with the intent of helping them resolve a past challenge that was limiting their capacity to serve. Specifically, the assignment prompted students to first look at their own past contributions and write about one experience of fixing others, and one instance of serving others.

Like for Course One, the re-engagement tool moved students from the South to the North. They began in the South by considering a past experience of fixing rather than 
serving (Identifying and relating to aspects of themselves not free to serve). As part of relating to this past "self," they were prompted to describe the context, their motivations, and to attempt to identify the factors that elicited their fixing response. The next prompt guided students into the West (Empathetic analysis and discernment of feelings and needs). Students were asked to draw on Rosenberg's Nonviolent Communication framework to identify their basic human needs that were not met in the fixing experience. Contrasting their fixing with their serving supported this discernment further. They next moved through the East (Articulate/invoke civic vision or values), following a prompt to reflect on the kind of service they would most want to give. Finally, students were prompted to move to the North to discuss what they could do in order to be more skillful in meeting these needs going forward (Growth in capacity to use gifts, in service of vision, in civic sphere). The following section provides some background on the students who wrote these narrative papers as part of the study.

\section{$\underline{\text { Research Participants }}$}

The population of students in the study was determined by which students enrolled in the study courses and chose to participate in the study. The population was not representative of the larger PSU student body, nor was it representative of the students in the courses. In Course One, a disproportionate number of students of color chose not to participate. Specifically, five out of six students who elected not to participate were students of color. This created a significant bias and further studies need to address the imbalance here. A higher proportion of students in Course Two elected to participate. However, $94 \%$ of this study population was White. 
Table 3.1: Study Population for Course One

\begin{tabular}{|c|c|}
\hline Major & \\
\hline Physical Science & 1 \\
\hline Political Science & 3 \\
\hline Urban and Public Affairs & 2 \\
\hline Psychology/Social Work/Conflict Resolution/Social Science & 4 \\
\hline Business & 3 \\
\hline Civic Leadership Minor & 3 \\
\hline Race/Ethnicity & \\
\hline Latinx & 3 \\
\hline African or African American & 0 \\
\hline Middle Eastern or Arab-American & 2 \\
\hline White & 8 \\
\hline Gender & \\
\hline Female & 6 \\
\hline Male & 7 \\
\hline Nonbinary & 0 \\
\hline
\end{tabular}

Table 3.2: Study Population for Course Two

\begin{tabular}{|l|l|}
\hline Major & \\
\hline Physical/Health Science & 2 \\
\hline Political Science & 4 \\
\hline Urban and Public Affairs & 2 \\
\hline
\end{tabular}




\begin{tabular}{|l|l|}
\hline Psychology/Social Work/Conflict Resolution/Community Dev. & 4 \\
\hline Arts and Letters/Social Science & 2 \\
\hline Humanities & 2 \\
\hline & \\
\hline Civic Leadership Minor & 2 \\
\hline & \\
\hline Race/Ethnicity & \\
\hline Latinx & 0 \\
\hline African or African American & 1 \\
\hline Middle Eastern or Arab-American & 0 \\
\hline White & 15 \\
\hline & \\
\hline Gender & 11 \\
\hline Female & 3 \\
\hline Male & 2 \\
\hline Nonbinary & \\
\hline
\end{tabular}

\section{Data Collection}

The goal of data collection was to generate useful information about how the implementation of the HCEE model impacted students' learning and their capacity for civic engagement. Most data was collected from student essays and written work. Each class also included a pre-assessment to collect data on students' initial knowledge about engagement and service. The in-person course allowed for observational data to be collected, as well as generation of data through in-class exercises and reflections. This included a final self-reflection and reflection on the course and course learning. Regular 
instructor reflections during implementation of both courses also contributed to the data. While an optional focus group was planned after the in-person course, and I elicited input into ideal timing for this during exam week, no students attended. Though data analysis should allow a better understanding of students' learning, the focus is on how students responded to the narrative sequence. The evidence gathered is evidence that speaks to patterns in the nature and depth of this learning.

\section{Use of Rubrics in the Study}

Rubrics are typically used in educational research as a tool to support data collection and assessment (Reddy \& Andrade, 2010). Specifically, Wald et al. (2012) developed a rubric to analyze reflective writing in higher education. They tested their rubric empirically to assess its validity for use in formative assessment. Appendix $\mathrm{J}$ contains their result, the Reflection Evaluation for Learners' Enhanced Competencies Tool (REFLECT). This tool identifies four levels of reflective learning: Habitual action (Nonreflective), Thoughtful action or introspection, Reflection, and Critical Reflection (Wald, et al., 2012). I developed the assessment rubrics for the assignments based on these four levels of reflection. To determine the content of the rubric, I placed the learning outcomes on the vertical axis (a substitution from the generic outcomes given in the REFLECT), then for each outcome I asked what Habitual, Thoughtful, Reflective and Critically Reflective responses might look like.

Approval, Consent, and Protection of Human Subjects

Before beginning data collection, approval was obtained from Portland State University's Institutional Review Board. On the first day of class, I introduced the study, 
clarified that participation would not affect grades, and distributed a consent form. The online course form was distributed as a Google survey. I communicated that the data that I would collect was comprised of the work students generated for the class. Thus, by giving consent, they were aware that any class writing or contribution could become part of the study. Students' identities have been kept confidential, with pseudonyms assigned for reporting data. Classroom observations were stored on a password-protected computer. No information about grades, medical information, or immigration status is shared in the dissertation. Identifying details about students has been modified. The emotional risk to participants in the study who shared personal experiences was mitigated by an effort to develop supportive relationships between students, and between students and instructor. All in-class and online sharing prompts allowed room to share either quite personally, or less so, without impact on grades. I did my best to frame opportunities for disclosure as opportunities for increasing awareness and purposeful action. This was intended to minimize the possibility that students' sharing of vulnerability would lead to a self-identification with victimhood, and undermine their empowerment. Through readings and in-class comments, I attempted (while teaching critical thinking) to acknowledge the value of all students' contributions in class and in civic community.

\section{Course One Data Collection}

Eight strategies were used in Course One to generate data to inform the study:

\section{Pre-Assessment}

2. Narrative Part One (Dis/Engagement Narrative)

3. Narrative Part Two (Contextualization of Disengagement: Letter to Self) 
4. Narrative Part Three (Civic Vision Narrative)

5. Dear Jane notes (open-ended daily assessment)

6. Student self-assessment and reflection on class community

7. Instructor memos and reflection

The following section describes each of these data collection strategies. It explains the role of each in addressing the research question, and how the strategies were implemented to generate data. Where the strategy took the form of a written assignment, this section presents the learning outcomes and assessment rubrics used.

\section{Pre-Assessment}

The pre-assessment tool gave students open-ended prompts in order to assess their understanding of civic engagement generally. This strategy was not designed to enable direct, individual, comparison with a post-assessment. Rather, the purpose of the preassessment, in the context of this action research study, was to determine students' previous knowledge in order to inform and strengthen the implementation of the model. This data was also relevant for developing other areas of the curriculum to better address gaps in understanding.

I used two tools as part of the pre-assessment. The first was an open-ended, informal questionnaire. The second was a class-wide discussion. The format of the discussion was a "word splash," an activity in which students responded out loud to prompts, which were recorded and grouped on the board. While the first component focused on the individual, the second exercise assessed what students could further generate when aided with prompts and examples from others. 


\section{Individual Pre-Assessment}

Students responded on their own paper to questions I wrote on the board. The intention of this format was to reduce the formality of the assessment, encouraging honest responses by minimizing any resemblance to a test or quiz. To minimize the influence I might have on students' responses, I took several measures. I put the assessment first on the agenda after basic introductions so the rest of day's content would not factor in their responses. I also did not rearrange the room into a circle and left the default rows intact in order not to cue students that I valued participation. After describing what I meant by each prompt and answering questions, students responded in silence with no time limit. Some students did not bring paper the first day of class, so I instructed everyone with extra paper to share as needed.

The questions were:

1. What are you bringing to class? [thoughts, feelings, ideas, concerns]

2. What makes a person civically engaged? [What actions, thoughts or feelings?]

3. How does a person know they are effective in their civic engagement?

\section{Group Pre-Assessment}

In addition to individual knowledge, I assessed class-wide knowledge. After the Free Write assessment and a syllabus review, I wrote the term "Civic Engagement" on the board and asked students to share responses to the prompt "What does civic engagement look like?" Students shared responses, which I wrote down as a "word splash,” placing answers around the phrase "Civic Engagement." The purpose of this was to emphasize that the discussion was a brainstorm rather than a definitive or ordered list. 


\section{Narrative Part One (Dis/Engagement Narrative)}

As a data collection strategy, this essay assignment would elicit information about the impact of the core narrative sequence. However, this information was only partly intended to inform whether the narrative impacted students. The more important focus for this study was how the narrative impacted students. This second question was relevant because patterns in student learning would inform the model. Data collection would reveal how the narrative's prompts were being interpreted, what responses they were eliciting in students, and what insights they seemed to generate. The students' writing would reveal how they explained why an experience had been engaging or not. In this way, the assignment would bring insight into students' capacity for this kind of internal awareness. Finally, the data generated by this assignment would help reveal generally what kinds of experiences students had found engaging and disengaging in their pasts.

The learning outcomes for this assignment were: (1) students will bring awareness to the factors that led them to feel engaged, and (2) students will bring awareness to the factors that led them to feel disengaged. The primary focus of analysis was understanding the impact of these prompts. The following rubric (Table 3.3) was used to assess the degree to which these outcomes were demonstrated. 
Table 3.3: Assessment Rubric for Course One Narrative Part One

\begin{tabular}{|c|c|c|c|c|}
\hline $\begin{array}{l}\text { Learning } \\
\text { Outcome }\end{array}$ & $\begin{array}{c}\text { Not yet } \\
\text { developed }\end{array}$ & $\begin{array}{c}\text { Initial } \\
\text { development }\end{array}$ & Developed & Well-developed \\
\hline \begin{tabular}{|l|} 
Students will \\
bring awareness \\
to the factors that \\
led them to feel \\
engaged.
\end{tabular} & $\begin{array}{l}\text { Student does not } \\
\text { identify specific } \\
\text { life instances or } \\
\text { does not } \\
\text { distinguish } \\
\text { clearly between } \\
\text { engaging and } \\
\text { disengaging } \\
\text { experiences. }\end{array}$ & $\begin{array}{l}\text { Student uses } \\
\text { general language } \\
\text { to describe what } \\
\text { might be generally } \\
\text { engaging rather } \\
\text { than speaking from } \\
\text { experience. } \\
\text { Student names } \\
\text { non-specific } \\
\text { factors. }\end{array}$ & $\begin{array}{l}\text { Student names } \\
\text { specific factors } \\
\text { that led to feeling } \\
\text { engaged, but } \\
\text { does not } \\
\text { elaborate on the } \\
\text { internal } \\
\text { experience of } \\
\text { engagement. }\end{array}$ & $\begin{array}{l}\text { Student gives } \\
\text { significant detail about } \\
\text { the factors of their } \\
\text { engagement and the } \\
\text { impact internally of } \\
\text { those factors. }\end{array}$ \\
\hline $\begin{array}{l}\text { Students will } \\
\text { bring awareness } \\
\text { to the factors that } \\
\text { led them to feel } \\
\text { disengaged }\end{array}$ & $\begin{array}{l}\text { Student does not } \\
\text { identify specific } \\
\text { life instances or } \\
\text { does not } \\
\text { distinguish } \\
\text { clearly between } \\
\text { engaging and } \\
\text { disengaging } \\
\text { experiences. }\end{array}$ & $\begin{array}{l}\text { Student uses } \\
\text { general language } \\
\text { to describe what } \\
\text { might be generally } \\
\text { disengaging rather } \\
\text { than speaking from } \\
\text { experience. } \\
\text { Student names } \\
\text { non-specific } \\
\text { factors. }\end{array}$ & $\begin{array}{l}\text { Student names } \\
\text { specific factors } \\
\text { that led to feeling } \\
\text { disengaged, but } \\
\text { does not } \\
\text { elaborate on the } \\
\text { internal } \\
\text { experience of } \\
\text { disengagement. }\end{array}$ & $\begin{array}{l}\text { Student gives } \\
\text { significant detail about } \\
\text { the factors of their } \\
\text { disengagement and the } \\
\text { impact internally of } \\
\text { those factors. }\end{array}$ \\
\hline
\end{tabular}

\section{Narrative Part Two (Contextualization of Disengagement: Letter to Self)}

The role of the data generated from the second narrative assignment was to inform understanding of the degree to which students learned to use the re-engagement process tool. This strategy also provided more general insight into how students responded to implementing this process. The essays were primarily used to provide this more general information in service of revealing insights about the model. However, the rubric was also an important tool in determining the extent of learning. Unlike the first essay in the narrative sequence, this second essay was not introduced with an in-class activity. Rather, the paper assignment was distributed as a handout, accompanied by a verbal rationale and responses to questions. 
The first three learning outcomes for part two of the narrative sequence mapped to the three steps in the re-engagement process tool. The fourth learning goal was that students would value the tool as something that could potentially support their goals for growth in political efficacy. The intended learning outcomes were: (1) students will draw on the practice on Nonviolent Communication to empathetically analyze an experience of disengagement, (2) students will create context for their disengagement. They will understand their reasons for disengaging and acknowledge that those reasons were valid in the past, but are no longer relevant in the present. They will practice bringing new awareness and insight to their disengagement in a way that allows them the opportunity to re-engage, (3) students will use their commitment to their vision or values to re-engage where they had been disengaged, and (4) students will understand that political behavior - their own and others' — can be shaped by past experiences of disengagement. The following rubric (Table 3.4) guided assessment of student learning toward these aims.

Table 3.4: Assessment Rubric for Course One Narrative Part Two

\begin{tabular}{|l|l|l|l|l|}
\hline \multicolumn{1}{|c|}{ Learning Outcome } & \multicolumn{1}{|c|}{$\begin{array}{c}\text { Not yet } \\
\text { developed }\end{array}$} & $\begin{array}{c}\text { Initial } \\
\text { development }\end{array}$ & Developed & Well-developed \\
\hline $\begin{array}{l}\text { Students will draw on the } \\
\text { practice on Nonviolent } \\
\begin{array}{l}\text { Communication to } \\
\text { empathetically analyze an } \\
\text { experience of } \\
\text { disengagement }\end{array}\end{array}$ & $\begin{array}{l}\text { Student uses } \\
\text { judgmental } \\
\text { language or } \\
\text { does not name } \\
\text { feelings or } \\
\text { needs. }\end{array}$ & $\begin{array}{l}\text { Student names } \\
\text { feelings and } \\
\text { needs but does } \\
\text { so with blame } \\
\text { or judgment } \\
\text { toward the } \\
\text { disengaged self. }\end{array}$ & $\begin{array}{l}\text { Student names } \\
\text { feelings and } \\
\text { needs. }\end{array}$ & $\begin{array}{l}\text { Student names } \\
\text { feelings and needs } \\
\text { and elaborates with } \\
\text { description of those } \\
\text { specific } \\
\text { experiences. }\end{array}$ \\
\hline
\end{tabular}




\begin{tabular}{|c|c|c|c|c|}
\hline Learning Outcome & $\begin{array}{c}\text { Not yet } \\
\text { developed }\end{array}$ & $\begin{array}{c}\text { Initial } \\
\text { development }\end{array}$ & Developed & Well-developed \\
\hline $\begin{array}{l}\text { Students will } \\
\text { acknowledge that the } \\
\text { reasons for } \\
\text { disengagement were valid } \\
\text { in the past, but are no } \\
\text { longer relevant in the } \\
\text { present. They will bring } \\
\text { new awareness and } \\
\text { insight to their } \\
\text { disengagement in a way } \\
\text { that allows them the } \\
\text { opportunity to re-engage. }\end{array}$ & $\begin{array}{l}\text { Student does } \\
\text { not } \\
\text { acknowledge } \\
\text { reasons for } \\
\text { disengagement } \\
\text { or respond } \\
\text { meaningfully. }\end{array}$ & $\begin{array}{l}\text { Student } \\
\text { acknowledges } \\
\text { reasons for } \\
\text { disengagement } \\
\text { but does not } \\
\text { bring new } \\
\text { awareness to } \\
\text { the disengaged } \\
\text { self. }\end{array}$ & $\begin{array}{l}\text { Student } \\
\text { acknowledges } \\
\text { reasons for } \\
\text { disengagement } \\
\text { and describes } \\
\text { context for that } \\
\text { disengagement. }\end{array}$ & $\begin{array}{l}\text { Student } \\
\text { acknowledges } \\
\text { reasons for } \\
\text { disengagement, and } \\
\text { richly describes } \\
\text { contextual factors } \\
\text { relating to the } \\
\text { disengagement. }\end{array}$ \\
\hline $\begin{array}{l}\text { Students will use their } \\
\text { commitment to their } \\
\text { vision or values to re- } \\
\text { engage where they had } \\
\text { been disengaged. }\end{array}$ & \begin{tabular}{|l} 
Student does \\
not name a \\
vision or values.
\end{tabular} & $\begin{array}{l}\text { Student names a } \\
\text { general or } \\
\text { generic vision. }\end{array}$ & $\begin{array}{l}\text { Student names } \\
\text { values and } \\
\text { visions that } \\
\text { directly relate } \\
\text { to this } \\
\text { disengaging } \\
\text { experience. }\end{array}$ & \begin{tabular}{|l|} 
Student richly \\
describes values \\
and visions that \\
specifically require \\
the disengaged self \\
to re-engage.
\end{tabular} \\
\hline $\begin{array}{l}\text { Students will understand } \\
\text { that political behavior-- } \\
\text { their own and others'- } \\
\text { can be shaped by past } \\
\text { experiences of } \\
\text { disengagement. }\end{array}$ & \begin{tabular}{|l|} 
Student does \\
not write about \\
political or civic \\
behavior \\
generally.
\end{tabular} & $\begin{array}{l}\text { Student refers } \\
\text { generally to } \\
\text { increasing } \\
\text { "engagement" } \\
\text { without } \\
\text { specifics. }\end{array}$ & $\begin{array}{l}\text { Student writes } \\
\text { generally that } \\
\text { disengaging } \\
\text { experiences can } \\
\text { inhibit political } \\
\text { efficacy. }\end{array}$ & $\begin{array}{l}\text { Student describes } \\
\text { specifically how } \\
\text { this instance of } \\
\text { disengagement } \\
\text { related to a } \\
\text { negative pattern of } \\
\text { political behavior } \\
\text { and indicates a new } \\
\text { intention. }\end{array}$ \\
\hline
\end{tabular}

\section{Narrative Part Three (Civic Vision Narrative)}

The last essay in the narrative sequence was used to generate data about students' capacity to identify civic visions and qualities of civic leadership. It was also used to understand students' ability to apply the re-engagement process tool without being specifically guided through the steps. The learning outcomes for this assignment were:

(1) students will identify a civic vision that aligns with democratic principles and values, (2) students will identify leadership qualities that emerged from the course and/or from current theories about civic leadership such as New Public Service, (3) students will 
honestly assess personal challenges in terms of what growth they aspire to in order to lead toward their vision(s), and (4) students will bring empathy to their challenges and adopt a more empowered orientation toward meeting those challenges. This essay assignment was created after reading and assessing part two of the narrative sequence. The assignment handout was given in class and accompanied by a visual explanation showing the interrelationship of the four prompts. To assess learning toward the intended outcomes, the following rubric (Table 3.5) was used:

Table 3.5: Assessment Rubric for Course One Narrative Part Three

\begin{tabular}{|c|c|c|c|c|}
\hline Learning Outcome & $\begin{array}{c}\text { Not yet } \\
\text { developed }\end{array}$ & $\begin{array}{c}\text { Initial } \\
\text { development }\end{array}$ & Developed & Well-developed \\
\hline $\begin{array}{l}\text { Students will identify a } \\
\text { civic vision that aligns } \\
\text { with democratic } \\
\text { principles and values. }\end{array}$ & $\begin{array}{l}\text { Student does } \\
\text { not identify a } \\
\text { vision or } \\
\text { identifies a } \\
\text { vision that is } \\
\text { not aligned with } \\
\text { democratic } \\
\text { principles. }\end{array}$ & $\begin{array}{l}\text { Student } \\
\text { identifies a } \\
\text { general vision } \\
\text { aligned with } \\
\text { democratic } \\
\text { principles. }\end{array}$ & $\begin{array}{l}\text { Student identifies } \\
\text { a specific civic } \\
\text { vision aligned } \\
\text { with democratic } \\
\text { values. }\end{array}$ & $\begin{array}{l}\text { Student identifies } \\
\text { a specific and } \\
\text { personal civic } \\
\text { vision aligned } \\
\text { with democratic } \\
\text { values. They } \\
\text { describe how } \\
\text { their personal } \\
\text { vision relates to a } \\
\text { shared vision. }\end{array}$ \\
\hline $\begin{array}{l}\text { Students will identify } \\
\text { leadership qualities that } \\
\text { emerged from the course } \\
\text { and/or from current } \\
\text { theories about civic } \\
\text { leadership such as New } \\
\text { Public Service. }\end{array}$ & $\begin{array}{l}\text { Student does } \\
\text { not identify } \\
\text { leadership } \\
\text { qualities or } \\
\text { identifies } \\
\text { qualities that are } \\
\text { not aligned with } \\
\text { democratic } \\
\text { principles. }\end{array}$ & $\begin{array}{l}\text { Student } \\
\text { identifies } \\
\text { leadership } \\
\text { qualities } \\
\text { aligned with } \\
\text { democratic } \\
\text { principles. }\end{array}$ & \begin{tabular}{|l} 
Student identifies \\
leadership \\
qualities aligned \\
with democratic \\
principles and \\
describes how \\
these qualities \\
benefit civic \\
engagement.
\end{tabular} & $\begin{array}{l}\text { Student identifies } \\
\text { leadership } \\
\text { qualities that } \\
\text { specifically serve } \\
\text { their civic vision. }\end{array}$ \\
\hline $\begin{array}{l}\text { Students will honestly } \\
\text { assess personal challenges } \\
\text { in terms of what growth } \\
\text { they aspire to in order to } \\
\text { lead toward their } \\
\text { vision(s). }\end{array}$ & $\begin{array}{l}\text { Student does } \\
\text { not name any } \\
\text { challenges or } \\
\text { names general } \\
\text { challenges. }\end{array}$ & $\begin{array}{l}\text { Student names } \\
\text { personal } \\
\text { challenges } \\
\text { briefly. }\end{array}$ & \begin{tabular}{|l|} 
Student names \\
personal \\
challenges \\
specifically and \\
alludes to growth \\
needed.
\end{tabular} & \begin{tabular}{|l} 
Student names \\
personal \\
challenges \\
specifically and \\
lists action steps \\
toward the \\
growth needed.
\end{tabular} \\
\hline
\end{tabular}




\begin{tabular}{|l|l|l|l|l|}
\hline \multicolumn{1}{|c|}{ Learning Outcome } & \multicolumn{1}{|c|}{$\begin{array}{c}\text { Not yet } \\
\text { developed }\end{array}$} & $\begin{array}{c}\text { Initial } \\
\text { development }\end{array}$ & Developed & Well-developed \\
\hline $\begin{array}{l}\text { Students will bring } \\
\text { empathy to their } \\
\text { challenges and adopt a } \\
\text { more empowered } \\
\text { orientation toward } \\
\text { meeting those challenges. }\end{array}$ & $\begin{array}{l}\text { Student does } \\
\text { not name } \\
\text { feelings or } \\
\text { needs. }\end{array}$ & $\begin{array}{l}\text { Student names } \\
\text { feelings and } \\
\text { needs but brings } \\
\text { a dismissive or } \\
\text { judgmental } \\
\text { tone. }\end{array}$ & $\begin{array}{l}\text { Student names } \\
\text { feelings and } \\
\text { needs and alludes } \\
\text { to possible future } \\
\text { growth. }\end{array}$ & $\begin{array}{l}\text { Student names } \\
\text { feelings and } \\
\text { needs and refers } \\
\text { to the } \\
\text { opportunities } \\
\text { generated. }\end{array}$ \\
\hline
\end{tabular}

\section{Dear Jane notes}

This strategy for data collection was intended to elicit honest and informal feedback about the impact of the model and curriculum. The prompt for every "Dear Jane" note was simply "Write me a note starting with 'Dear Jane' and tell me anything you want me to know." Students responded to this prompt on their own paper in the last few minutes of class. Instructionally, the goal of this was to maintain open communication. As a source of data, the Dear Jane notes were largely not informative in regard to the research question. Occasionally, students did note when something was impactful or challenging about the curriculum. However, the majority of notes expressed gratitude, or shared concerns students had about their schedules and responsibilities outside class. When students did refer to the curriculum, I coalesced this data and included it in the analysis.

\section{Final Self-Assessment and Reflection on Class Community}

Two assessment exercises were given at the end of Course One, though they were not intended as post-assessments that could be compared to the pre-assessment. Rather, these exercises were structured as open-ended prompts to elicit data about students' growth and learning, their goals for the future, and their experience of the class as a 
community. This data was useful in exploring the impact of both the narrative sequence and the course generally as applications of the model.

\section{Summary of Course One Data Collection}

Table 3.6 summarizes the desired learning outcomes for each dimension in Course

One. It also shows the strategies used to assess learning toward the outcomes. The core narrative sequence and the behavioral dimension were the priorities for assessment, but data was generated to assess growth in the other dimensions as well. It is important to note that the dimensions shown here are the primary, not the only, dimensions developed —in reality, all the dimensions inform the learning goals.

Table 3.6: Course One Learning Outcomes and Data Collection Strategies by Primary Dimension

\begin{tabular}{|l|l|l|}
\hline Dimension & \multicolumn{1}{|c|}{ Learning Outcomes } & \multicolumn{1}{|c|}{$\begin{array}{c}\text { Data Collection } \\
\text { Strategy }\end{array}$} \\
\hline Behavioral & $\begin{array}{l}\text { Students will use their commitment to their vision or } \\
\text { values to re-engage where they had been disengaged. }\end{array}$ & Narrative Part 2 \\
\cline { 2 - 3 } & $\begin{array}{l}\text { Students will bring empathy to their challenges and adopt } \\
\text { a more empowered orientation toward meeting those } \\
\text { challenges. }\end{array}$ & Narrative Part 3 \\
\hline Emotional & $\begin{array}{l}\text { Students will bring awareness to the factors that lead } \\
\text { them to feel engaged. }\end{array}$ & Narrative Part 1 \\
\cline { 2 - 4 } & $\begin{array}{l}\text { Students will bring awareness to the factors that lead } \\
\text { them to feel disengaged. }\end{array}$ & Narrative Part 1 \\
\cline { 2 - 4 } & $\begin{array}{l}\text { Students will honestly assess personal challenges in terms } \\
\text { of what growth they aspire to in order to lead toward their } \\
\text { vision(s). }\end{array}$ & Narrative Part 3 \\
\hline Cognitive & $\begin{array}{l}\text { Students will create context for their disengagement. } \\
\text { They will understand their reasons for disengaging and } \\
\text { acknowledge that those reasons were valid in the past, but } \\
\text { are no longer relevant in the present. They will practice } \\
\text { bringing new awareness and insight to their } \\
\text { disengagement in a way that allows them the opportunity } \\
\text { to re-engage. }\end{array}$ & Narrative Part 2 \\
\hline
\end{tabular}




\begin{tabular}{|l|l|l|}
\hline Dimension & \multicolumn{1}{|c|}{ Learning Outcomes } & \multicolumn{1}{|c|}{$\begin{array}{c}\text { Data Collection } \\
\text { Strategy }\end{array}$} \\
\hline \multirow{3}{*}{} & $\begin{array}{l}\text { Students will understand that political behavior-their } \\
\text { own and others_can be shaped by past experiences of } \\
\text { disengagement. }\end{array}$ & Narrative Part 2 \\
\cline { 2 - 3 } & $\begin{array}{l}\text { Students will identify a civic vision that aligns with } \\
\text { democratic principles and values. }\end{array}$ & Narrative Part 3 \\
\cline { 2 - 4 } & $\begin{array}{l}\text { Students will identify leadership qualities that emerged } \\
\text { from the course and/or from current theories about civic } \\
\text { leadership such as New Public Service. }\end{array}$ & Narrative Part 3 \\
\hline Spiritual & $\begin{array}{l}\text { Students will draw on the principles of Nonviolent } \\
\text { Communication to compassionately analyze an } \\
\text { experience of disengagement. }\end{array}$ & Narrative Part 2 \\
\hline
\end{tabular}

\section{Course Two Data Collection}

All data for Course Two, Fundamentals of Public Service, needed to be collected via the online class medium. Essays were submitted through the course website, the weekly reading discussion took place through the online forum, and the pre-assessment data was collected primarily via videos that individuals filmed and uploaded. I analyzed the student work elicited by four curricular components as well as instructor reflections.

The data collection strategies were:

1. Pre-Assessment videos/posts

2. Narrative Part One (Personal Public Service Reflection \#1)

3. Narrative Part Two (Personal Public Service Reflection \#2)

4. Weekly Discussion Posts

5. Instructor Memos and Reflections 
This section discusses these strategies and describes how each was used to generate data that could help address the research question, and presents the learning outcomes and assessment rubrics used for the written assignments.

\section{Pre-Assessment Videos/Posts}

To gather data on students' notions of "service" coming into the class, I asked them in Week One to create a video (or typed) post that described one positive experience with service and one challenging experience with service. This strategy was intended to gather data on students' honest understanding of "service" by asking about this indirectly; their definitions of service were implicit in their responses about positive and negative experiences with service. This post also posed questions meant to build trust in the group and gather data about how students related to one another. After describing experiences with service, I asked them to share "something we would not know about you unless you tell us" and "one thing you look forward to in your life this Spring." This data was useful in developing the curriculum specifically in response to this particular group of students. 2. Narrative Part One (Personal Public Service Reflection \#1)

Analyzing these essays as data helped to shed light on how this first narrative essay prompt impacted students. The essays gave insight into students' engagement in their form of service. They revealed how students understood the concepts of "helping," "fixing," and "serving," and showed the nature of their commitment to serving rather than fixing. The assignment also gave insight into how deeply students were able to consider the implications of fixing - how thoroughly could they let themselves feel how damaging fixing can be? Learning this would be important in helping students develop 
the commitment for service, especially the motivations needed for sustained service. The data generated from these student essays would also inform the design of the second narrative, which would build directly on these concepts. The aim was for students to show learning toward two outcomes: (1) students will be able to distinguish "fixing" from "serving," drawing on examples from their lives; they will describe the significance of this distinction, and (2) students will express the intention to offer service to others.

The following rubric (Table 3.7) was used to assess this learning:

Table 3.7: Rubric for Course Two Narrative Part One

\begin{tabular}{|c|c|c|c|c|}
\hline $\begin{array}{l}\text { Learning } \\
\text { Outcome }\end{array}$ & $\begin{array}{c}\text { Not yet } \\
\text { developed }\end{array}$ & $\begin{array}{c}\text { Initial } \\
\text { development }\end{array}$ & Developed & Well-developed \\
\hline $\begin{array}{l}\text { Students will be } \\
\text { able to distinguish } \\
\text { "fixing" from } \\
\text { "serving," } \\
\text { drawing on } \\
\text { examples from } \\
\text { their lives. They } \\
\text { will describe the } \\
\text { significance of } \\
\text { this distinction. }\end{array}$ & $\begin{array}{l}\text { Student conflates } \\
\text { or incorrectly } \\
\text { defines fixing } \\
\text { and serving. }\end{array}$ & $\begin{array}{l}\text { Student shows a } \\
\text { basic } \\
\text { understanding of } \\
\text { the distinction, } \\
\text { but the examples } \\
\text { are not clearly } \\
\text { aligned. }\end{array}$ & $\begin{array}{l}\text { Student shows an } \\
\text { understanding of } \\
\text { the distinction and } \\
\text { gives examples } \\
\text { that clearly } \\
\text { illustrate this. } \\
\text { They give a basic } \\
\text { explanation of the } \\
\text { significance of the } \\
\text { distinction. }\end{array}$ & $\begin{array}{l}\text { Student shows a clear } \\
\text { understanding of the } \\
\text { distinction and gives } \\
\text { examples that richly } \\
\text { illustrate this. They } \\
\text { explain the } \\
\text { significance of the } \\
\text { distinction with } \\
\text { reference to fixing } \\
\text { and serving on an } \\
\text { institutional level. }\end{array}$ \\
\hline $\begin{array}{l}\text { Students will } \\
\text { express the } \\
\text { intention to offer } \\
\text { service to others. }\end{array}$ & $\begin{array}{l}\text { Student does not } \\
\text { write about a } \\
\text { preference to } \\
\text { serve rather than } \\
\text { fix. }\end{array}$ & $\begin{array}{l}\text { Student refers } \\
\text { generally to } \\
\text { serving as more } \\
\text { preferable than } \\
\text { fixing. }\end{array}$ & $\begin{array}{l}\text { Student writes } \\
\text { about the general } \\
\text { and personal } \\
\text { importance of } \\
\text { serving and the } \\
\text { harm of fixing. }\end{array}$ & $\begin{array}{l}\text { Student writes about } \\
\text { the personal and } \\
\text { political or } \\
\text { institutional benefits } \\
\text { of serving and issues } \\
\text { with fixing. They } \\
\text { express personal } \\
\text { commitment and } \\
\text { intention. }\end{array}$ \\
\hline
\end{tabular}

\section{Narrative Part Two (Personal Public Service Reflection \#2)}

This assignment, completed in Week Seven, was intended to prompt students through the steps of using the re-engagement practice tool. The data generated here 
provided insight into how students were working with the tool. It showed how deftly and deeply they could respond to the reflection process that the tool was designed to facilitate. It also revealed how creative and responsive students could be in working with the visioning and planning stages of applying the tool. Specifically, this assignment generated data informing how the re-engagement process tool impacted students when applied to the aim of re-engagement for public service. The learning outcomes for this assignment were: (1) students will demonstrate understanding of the helping/serving distinction through describing an example of their own past service, (2) students will identify specific needs, based on reflection of their past experience of service, that they must meet in order to serve effectively going forward, (3) students will identify at least one step they can take toward meeting their needs in order to serve, and (4) students will describe what they can gain by meeting their needs for service. The rubric below (Table 3.8) was used for assessment.

Table 3.8: Rubric for Course Two Narrative Part Two

\begin{tabular}{|c|c|c|c|c|}
\hline Learning Outcome & $\begin{array}{c}\text { Not yet } \\
\text { developed }\end{array}$ & $\begin{array}{c}\text { Initial } \\
\text { development }\end{array}$ & Developed & Well-developed \\
\hline $\begin{array}{l}\text { Students will demonstrate } \\
\text { understanding of the } \\
\text { helping/serving distinction } \\
\text { through describing an } \\
\text { example of their own past } \\
\text { service. }\end{array}$ & $\begin{array}{l}\text { Student } \\
\text { conflates or } \\
\text { incorrectly } \\
\text { defines fixing } \\
\text { and serving. }\end{array}$ & $\begin{array}{l}\text { Student shows } \\
\text { a basic } \\
\text { understanding } \\
\text { of the } \\
\text { distinction, but } \\
\text { the examples } \\
\text { are not clearly } \\
\text { aligned. }\end{array}$ & $\begin{array}{l}\text { Student shows } \\
\text { an understanding } \\
\text { of the distinction } \\
\text { and gives } \\
\text { examples that } \\
\text { clearly illustrate } \\
\text { this. }\end{array}$ & $\begin{array}{l}\text { Student shows a } \\
\text { clear understanding } \\
\text { of the distinction } \\
\text { and gives examples } \\
\text { that richly illustrate } \\
\text { this taking full, } \\
\text { compassionate } \\
\text { responsibility for the } \\
\text { instance of fixing. }\end{array}$ \\
\hline
\end{tabular}




\begin{tabular}{|c|c|c|c|c|}
\hline Learning Outcome & $\begin{array}{c}\text { Not yet } \\
\text { developed }\end{array}$ & $\begin{array}{c}\text { Initial } \\
\text { development }\end{array}$ & Developed & Well-developed \\
\hline $\begin{array}{l}\text { Students will identify } \\
\text { specific needs, based on } \\
\text { reflection upon their past } \\
\text { experience of service, } \\
\text { that they must meet in } \\
\text { order to serve effectively } \\
\text { going forward. }\end{array}$ & $\begin{array}{l}\text { Student uses } \\
\text { judgmental } \\
\text { language or } \\
\text { does not } \\
\text { name needs. }\end{array}$ & $\begin{array}{l}\text { Student names } \\
\text { needs but does } \\
\text { so with blame } \\
\text { or judgment } \\
\text { toward the self. }\end{array}$ & $\begin{array}{l}\text { Student names } \\
\text { needs with clear } \\
\text { connection to } \\
\text { their reflection on } \\
\text { their instance of } \\
\text { serving. }\end{array}$ & $\begin{array}{l}\text { Student richly } \\
\text { describes the needs } \\
\text { with clear } \\
\text { connection to their } \\
\text { reflection on their } \\
\text { instance of serving. }\end{array}$ \\
\hline $\begin{array}{l}\text { Students will identify at } \\
\text { least one step they can } \\
\text { take toward meeting their } \\
\text { needs in order to serve. }\end{array}$ & $\begin{array}{l}\text { Student does } \\
\text { not identify } \\
\text { any steps. }\end{array}$ & $\begin{array}{l}\text { Student } \\
\text { identifies steps } \\
\text { that are general } \\
\text { and not } \\
\text { connected to } \\
\text { the student's } \\
\text { specific needs. }\end{array}$ & $\begin{array}{l}\text { Student identifies } \\
\text { steps that are } \\
\text { general though } \\
\text { directly } \\
\text { connected to the } \\
\text { student's specific } \\
\text { needs. }\end{array}$ & $\begin{array}{l}\text { Student identifies } \\
\text { steps that are } \\
\text { specific, realistic, } \\
\text { and directly } \\
\text { connected to the } \\
\text { student's needs. }\end{array}$ \\
\hline $\begin{array}{l}\text { Students will describe } \\
\text { what they can gain by } \\
\text { meeting their needs for } \\
\text { service. }\end{array}$ & $\begin{array}{l}\text { Student does } \\
\text { not refer to } \\
\text { what can be } \\
\text { gained } \\
\text { through } \\
\text { meeting } \\
\text { needs. }\end{array}$ & $\begin{array}{l}\text { Student refers } \\
\text { generally to a } \\
\text { sense of } \\
\text { improvement or } \\
\text { growth if they } \\
\text { meet needs. }\end{array}$ & $\begin{array}{l}\text { Student refers } \\
\text { specifically to an } \\
\text { area for } \\
\text { improvement or } \\
\text { growth if they } \\
\text { meet needs. }\end{array}$ & $\begin{array}{l}\text { Student refers } \\
\text { specifically to an } \\
\text { area for } \\
\text { improvement or } \\
\text { growth if they meet } \\
\text { needs, and they } \\
\text { articulate the larger } \\
\text { benefit to } \\
\text { community if they } \\
\text { do so. }\end{array}$ \\
\hline
\end{tabular}

\section{Weekly Discussion Posts}

The weekly discussion posts were drawn upon to generate data to inform students' learning of the theories and commitment for service. This data would inform learning on the cognitive dimension and would help inform a response to the secondary research question: What learning did students demonstrate in relation to holistic civic engagement capacities and competencies? Though this assignment was not part of the core narrative sequence, discussion post responses were helpful in informing student learning on the cognitive dimension. Growth in the cognitive dimension was an important goal in its own right, and could also facilitate learning on the other, inter-related, 
dimensions. Specifically, the assignment was designed to elicit critical reflection on the meaning of "service" and to help students refine their visions for their own service. Reflecting on the theories was intended partly to help students gain a sense of intellectual space from assumptions they may have held. Engaging with the critiques embodied in the theories was part of helping them make room for authentic consideration of their own values and visions around service.

The weekly discussion post assignment elicited summary and application of the readings. In the application portion of their posts, students revealed how they experienced the theories playing out in their civic worlds, especially New Public Service. In relating these impressions, students revealed the extent to which they were able to bring critical insight to their public work, bring insight to their own mental models about service, and use these reflections to commit to a meaningful and authentic conception - and expression—of service in their lives. The learning outcomes for the series of reading responses were: (1) students will understand the New Public Service framework and its critique of Old Public Administration and New Public Management, (2) students will register the value of New Public Service ethics such as community building, responsiveness, collaboration, compassion, and interconnection, (3) students will critique their own mental models, bringing awareness to ways they may have internalized the ethics of New Public Management or Old Public Administration, and (4) students will connect to their intrinsic motivation to serve - their care, desire to learn and grow, desire to contribute to the whole — and authentically commit to service. 
Table 3.9: Rubric for Course Two Weekly Reading Response

\begin{tabular}{|c|c|c|c|c|}
\hline Learning Outcome & $\begin{array}{c}\text { Not yet } \\
\text { developed }\end{array}$ & $\begin{array}{c}\text { Initial } \\
\text { development }\end{array}$ & Developed & Well-developed \\
\hline $\begin{array}{l}\text { Students will } \\
\text { understand the New } \\
\text { Public Service (NPS) } \\
\text { framework and its } \\
\text { critique of Old Public } \\
\text { Administration (OPA) } \\
\text { and New Public } \\
\text { Management (NPM. }\end{array}$ & $\begin{array}{l}\text { Student does } \\
\text { not accurately } \\
\text { distinguish } \\
\text { between NPS } \\
\text { and NPM or } \\
\text { OPA. }\end{array}$ & $\begin{array}{l}\text { Student } \\
\text { distinguishes } \\
\text { between the } \\
\text { frameworks but } \\
\text { does not } \\
\text { articulate the } \\
\text { significance of } \\
\text { the distinctions. }\end{array}$ & \begin{tabular}{|l|} 
Student \\
distinguishes \\
between the \\
frameworks \\
and articulates \\
the significance \\
of the \\
distinctions.
\end{tabular} & $\begin{array}{l}\text { Student distinguishes } \\
\text { between the } \\
\text { frameworks, noting the } \\
\text { details and history that } \\
\text { form this distinction, } \\
\text { and articulates the } \\
\text { significance of the } \\
\text { distinctions. }\end{array}$ \\
\hline $\begin{array}{l}\text { Students will register } \\
\text { the value of New } \\
\text { Public Service ethics } \\
\text { such as community } \\
\text { building, } \\
\text { responsiveness, } \\
\text { collaboration, } \\
\text { compassion, and } \\
\text { interconnection. }\end{array}$ & $\begin{array}{l}\text { Student does } \\
\text { not name any } \\
\text { value of NPS } \\
\text { over NPM or } \\
\text { OPA. }\end{array}$ & $\begin{array}{l}\text { Student names } \\
\text { the value of NPS } \\
\text { generally but } \\
\text { does not } \\
\text { articulate the } \\
\text { impact of } \\
\text { applying NPS } \\
\text { principles. }\end{array}$ & \begin{tabular}{|l|} 
Student names \\
the value of \\
NPS and \\
articulates the \\
potential \\
impact of \\
applying NPS \\
principles.
\end{tabular} & $\begin{array}{l}\text { Student names the } \\
\text { value of NPS, } \\
\text { articulates the potential } \\
\text { impact of applying } \\
\text { NPS principles to } \\
\text { specific contexts. }\end{array}$ \\
\hline $\begin{array}{l}\text { Students will critique } \\
\text { their own mental } \\
\text { models, bringing } \\
\text { awareness to ways } \\
\text { they may have } \\
\text { internalized the ethics } \\
\text { of New Public } \\
\text { Management or Old } \\
\text { Public Administration. }\end{array}$ & $\begin{array}{l}\text { Student does } \\
\text { not refer to } \\
\text { their own } \\
\text { assumptions or } \\
\text { viewpoints. }\end{array}$ & $\begin{array}{l}\text { Student mentions } \\
\text { generally that } \\
\text { NPM and OPA } \\
\text { mental models } \\
\text { should be } \\
\text { critiqued or } \\
\text { reconsidered. }\end{array}$ & $\begin{array}{l}\text { Student writes } \\
\text { generally about } \\
\text { the need to } \\
\text { revise their } \\
\text { own mental } \\
\text { models about } \\
\text { service. }\end{array}$ & $\begin{array}{l}\text { Student writes } \\
\text { specifically about } \\
\text { beliefs, assumptions } \\
\text { and habits that they see } \\
\text { align with OPA or } \\
\text { NPM and offer a } \\
\text { specific alternative in } \\
\text { alignment with NPS } \\
\text { ethics. }\end{array}$ \\
\hline $\begin{array}{l}\text { Students will connect } \\
\text { to their intrinsic } \\
\text { motivation to serve- } \\
\text { their care, desire to } \\
\text { learn and grow, desire } \\
\text { to contribute to the } \\
\text { whole-and } \\
\text { authentically commit } \\
\text { to service. }\end{array}$ & $\begin{array}{l}\text { Student does } \\
\text { not mention } \\
\text { their } \\
\text { motivation for } \\
\text { service or } \\
\text { mentions a } \\
\text { motivation to } \\
\text { fix. }\end{array}$ & $\begin{array}{l}\text { Student writes } \\
\text { about their } \\
\text { motivation to } \\
\text { serve in general } \\
\text { terms, or in terms } \\
\text { of what they } \\
\text { "should" do. }\end{array}$ & $\begin{array}{l}\text { Student writes } \\
\text { about their } \\
\text { motivation to } \\
\text { serve with } \\
\text { reference to } \\
\text { goals and } \\
\text { intentions. }\end{array}$ & $\begin{array}{l}\text { Student writes about } \\
\text { their motivation to } \\
\text { serve and describes } \\
\text { their growth as a } \\
\text { motivation. They } \\
\text { describe how their } \\
\text { service forms part of } \\
\text { larger goals to which } \\
\text { they seek to contribute. }\end{array}$ \\
\hline
\end{tabular}

\section{Summary of Course Two Data Collection}

The following table (Table 3.10) shows all of the learning outcomes for Course

Two, Fundamentals of Public Service, and the data collection strategy for assessing each. 
The table is organized by primary holistic dimension to give a sense of how the

dimensions are being addressed through the learning outcomes via the data collection

strategies. As discussed, Course Two placed more emphasis on cognitive learning.

Table 3.10: Summary of Course Two Learning Outcomes and Data Collection Strategies by Primary Dimension

\begin{tabular}{|l|l|l|}
\hline $\begin{array}{c}\text { Primary } \\
\text { Dimension }\end{array}$ & \multicolumn{1}{|c|}{ Learning Outcomes } & \multicolumn{1}{|c|}{$\begin{array}{c}\text { Data Collection } \\
\text { Strategy }\end{array}$} \\
\hline Behavioral & $\begin{array}{l}\text { Students will identify specific needs, based on reflection } \\
\text { of their past experience of service, that they must meet in } \\
\text { order to serve effectively going forward. }\end{array}$ & Narrative Part 2 \\
\hline Emotional & $\begin{array}{l}\text { Students will express the intention to offer service to } \\
\text { others. }\end{array}$ & Narrative Part 1 \\
\cline { 2 - 3 } & $\begin{array}{l}\text { Students will (emotionally, and perhaps spiritually) } \\
\text { register the value of New Public Service ethics such as } \\
\text { community building, responsiveness, collaboration, } \\
\text { compassion, and interconnection. }\end{array}$ & Reading Responses \\
\hline Cognitive & $\begin{array}{l}\text { Students will be able to distinguish "fixing" from } \\
\text { "serving," drawing on examples from their lives. They } \\
\text { will describe the significance of this distinction. }\end{array}$ & Narrative Part 1 \\
\cline { 2 - 3 } & $\begin{array}{l}\text { Students will demonstrate understanding of the helping/ } \\
\text { serving distinction through describing an example of } \\
\text { their own past service. }\end{array}$ & Narrative Part 2 \\
\cline { 2 - 3 } & $\begin{array}{l}\text { Students will identify at least one step they can take } \\
\text { toward meeting their needs in order to serve. }\end{array}$ & Narrative Part 2 \\
\cline { 2 - 3 } & $\begin{array}{l}\text { Students will describe what they can gain by meeting } \\
\text { their needs for service. }\end{array}$ & Narrative Part 2 \\
\cline { 2 - 3 } & $\begin{array}{l}\text { Students will (cognitively) understand the New Public } \\
\text { Service framework and its critique of Old Public } \\
\text { Administration (hierarchical leadership in public sector) } \\
\text { and New Public Management (market-based logic } \\
\text { applied to public sector). }\end{array}$ & Reading Responses \\
\cline { 2 - 3 } & $\begin{array}{l}\text { Students will (cognitively) critique their own mental } \\
\text { models, bringing awareness to ways they may have } \\
\text { internalized the ethics of New Public Management or } \\
\text { Old Public Administration. }\end{array}$ & Reading Responses \\
\hline
\end{tabular}




\begin{tabular}{|l|l|l|}
\hline $\begin{array}{c}\text { Primary } \\
\text { Dimension }\end{array}$ & \multicolumn{1}{|c|}{ Learning Outcomes } & $\begin{array}{c}\text { Data Collection } \\
\text { Strategy }\end{array}$ \\
\hline Spiritual & $\begin{array}{l}\text { Students will (emotionally, and perhaps spiritually) } \\
\text { connect to their intrinsic motivation to serve - their care, } \\
\text { desire to learn and grow, desire to contribute to the } \\
\text { whole - and authentically commit to service. }\end{array}$ & Reading Responses \\
\hline
\end{tabular}

\section{Additional Data Collection: Instructor-Generated Data}

Instructor Memos and Reflections were also used in both courses to collect data.

For Course One, after each in-person session, I created an audio recording responding to the open-ended prompts "How was class?" and "What did I learn today that informs the curriculum?" For Course Two, given entirely online, I did this at least weekly, or more often if something occurred to me. This strategy for data collection was based on the action research principle of researcher reflection. These reflections were intended mostly to generate data about how the curriculum was impacting students and how it was impacting me. They were also intended to capture initial observations of patterns emerging, both in service of the final analysis process, or in service of responding and adapting as the course progressed. I chose the first prompt in order to capture more general responses to the class, about which I might not have known to ask directly. I selected the second prompt in order to capture any insights that arose when I thought explicitly about how the model had shaped the class planning and outcomes.

\section{Data Analysis}

Nearly all data generated by the study took the form of student written work. This aligned with the primary study goal to assess the impact of a sequence of assignments given in the context of a holistic civic engagement course. The data generated would need 
to be analyzed to assess impact, but in way that allowed for new findings to emerge, and data analysis processes would need to serve these two functions. Data would need to be analyzed to reveal the extent to which the learning outcomes were demonstrated by student work. However, data analysis also needed to inform the revision of the model. In this way, the data needed to serve to both evaluate and generate. Data analysis would enable evaluation of student learning based on rubrics and learning outcomes. However, the extent of student learning toward these outcomes is only valuable if this model and these outcomes are valuable in facilitating increased capacity for civic engagement.

\section{Evaluative Function}

The first function or data analysis was evaluative. Data was first analyzed, with close reference to the rubrics, to assess student learning toward the outcomes. This first reading took place in conjunction with grading. I read each essay and followed Wald et al.'s (2012) four-step process for assessing student work: (1) read the narrative, (2) zoom in to phrases/sentences of the narrative to assess the presence of the criteria, (3) zoom out to assess what level the narrative as a whole accomplishes, and (4) defend the assignment of level using student quotations. This approach to using rubrics allowed me to assess student work in terms of its reflectiveness and degree of engagement with the prompts of each assignment. I then made note of how many essays met each learning outcome at each level. These numbers I reported in the findings as "some," "many," "most" or "all" students. I chose to translate this quantitative finding into qualitative language to acknowledge the subjective nature of grading, even if using a rubric. I did not want the findings to imply a level of certainty that was not true to the data collection strategy and 
analysis process. The exception to this was in reporting on certain key findings where it seemed important to acknowledge the specific number of students who had fallen into that category.

\section{Generative Function}

The second function of data analysis was generative. By identifying patterns in how students responded to the curriculum, I sought to generate new questions, and insights into the model's impacts that I did not know to specifically seek out. Examples of questions that this second stage of data analysis could inform included: What obstacles to civic engagement are common in the study population? How did students show receptivity or resistance to the curriculum? What learning outcomes were reached, or not, that should be seen as necessary to the process? What could we learn from the students who were most successful in, and most challenged by, the process? And finally, how likely did it seem that achieving the learning outcomes could in fact increase students' capacity for civic engagement?

\section{Grounded Theory and Coding Process}

This second component of the data analysis process was open-ended and drew on grounded theory. In alignment with the aims of grounded theory, data was analyzed to build a meaningful response to the research question and inform the revision of the model (Charmaz, 2006). Grounded theory methods are "systematic, yet flexible guidelines for collecting and analyzing qualitative data to construct theories 'grounded' in the data themselves" (Charmaz, 2006, p. 2). Implementing grounded theory is intended to produce indicators and insight about a phenomenon rather than establishing an absolute finding 
—“theory generating" rather than "theory testing" (Lukas, 2008). Grounded theory studies follow a process of coding, sorting and reflecting in order to generate findings that originate in the data, are specific to the research context, and are usable by practitioners (Charmaz, 2006). For the purposes of this study, grounded theory could structure the process of eliciting meaningful information about how the holistic civic engagement curriculum impacted this group of students. Appendix I provides a sample of my analysis process for one of the assignments.

The coding process contained six steps, which began after the initial evaluative reading of essays. I analyzed the data by assignment, following the six steps for each assignment before moving to analyze the next assignment. The first step was writing a research memo responding to the prompts: Where did students exceed my expectations? Where did they fall short of the learning goals? As Charmaz (2006) suggests, these prompts were intended to harvest any patterns noted from the evaluation stage of reading. This first memoing prompt began the process of examining the impact of the curriculum on students.

The second step in the coding process was to re-read the data and identify quotes that provided information about students' learning in the context of the study. I collected these quotes and paraphrases in a document. The third step was to create themes while sorting the findings into themes. For each quotation or paraphrase, I asked the question "What does this suggest about the learning process?" As Charmaz (2006) states, themes are categories of information or findings about the question. This stage of analysis resulted in a long list of themes. 
The fourth step was to group these many themes into fewer, more general, but still accurate, themes. After this grouping, the fifth step was to re-read the quotations and paraphrases under each theme to assess how well the theme described the data. I revised the phrasing of the themes and reassigned some data to other themes. I also re-read the data that did not fit within a theme to determine whether it was useful as a counterexample, or appeared to be an outlier.

The sixth step was to write a second research memo. The prompt for this memo was “How would I describe what I found here?" This memo format, suggested by Charmaz (2006), allowed me to search for the most appropriate explanatory and descriptive language, pose questions, and critique my generalizations. At this point, I revised the language of the themes again. Finally, in writing the Results chapter, I noted where patterns seemed incoherent or overgeneralized, and revised the wording of the themes once again to reflect as closely as possible the pattern in the data. At this stage, I also confirmed that my qualitative markers noting the frequency of the patterns was accurate; I revised some of the language from "some" to "most," and vice versa. Research observations and reflections

I chose not to code my observation and reflection journal entries and audio recordings. Though action research values the learning and experience of the researcher, this study was not auto-ethnographic. A deep investigation into my experience of teaching the curriculum was not necessary in order to respond to the research question. The aim of "for you, for me, for us" embedded in the ethos of action research was achieved though the study because it was designed to benefit students, the Civic 
Leadership program, and my own teaching and academic work. The data generated from researcher reflections and observations was woven into and informed the identification of the themes. Where relevant, it was included in the reporting of the findings. I drew on this data in order to assess my own researcher bias and work to reduce it. This said, it would be a valuable contribution to the field to investigate how instructors respond to offering holistic civic engagement courses.

\section{Validity}

For quantitative studies, validity typically refers to appropriateness of data collection strategies, soundness of design, and generalizability. For qualitative studies, validity can refer to "the extent to which data reflect participants' views of the issue being explored" (Efron \& Ravid, 2019, p. 76). The validity of naturalistic inquiry, is "markedly different from experimental design" which means that "we have to re-appraise their meaning and use" (Norris, 1997, p. 172). This may be particularly true for the educational context. Schön (1995) argued that action research conducted by university faculty has "norms of its own, which will conflict with the norms of technical rationality-the prevailing epistemology built into the research universities" (p. 26). Because of this, it is important to consider different perspectives on validity as part of developing a study design. Here we look at two key conceptions of validity in educational action research. The first is a more narrow conception of validity typically adopted by action research scholars working specifically in education. The second is a more broad conception usually adopted by action researchers aiming toward social change. This study will draw 
on both criteria in order to implement a valid study of civic engagement teaching strategies.

Narrower conception of validity: Educational Action Research

Common in the scholarship of action research in educational contexts is a narrower conception of validity. While social change and empowerment are important aims, the primary focus, according to this view, is practitioner development in a given context (Altrichter, Posch, \& Somekh, 2008; Glesne, 1999; Stringer, 2004; York-Barr, et al., 2001). Action research is "reflective inquiry undertaken by educators in order to better understand the education environment and to improve practice" (Grady, 1998, p. 43). It does not set out to prove the effectiveness of the intervention; instead the goal is to improve the practitioner's practice (Efron \& Ravid, 2019). Schön wrote that action research studies start with "what the teacher knows," and then extend that understanding (Schön, 1995). Knowledge generated is not intended to be generalized and applied to other contexts. Instead, Schön (1995) argues, the impact of the study is that the teacher's "newly generated practice knowledge may be modified and incorporated into the practitioner's repertoire so as to be available for projection to further situations" (p. 31). As Efron \& Ravid (2019) synthesize, validity is determined by two factors - the quality of the educational approach and its appropriateness for the context.

Using this more narrow conception of validity, the practitioner is at the center of the impetus for the study. The quality of the practitioner's questions thus matter for the validity of the study. For example, McNiff, Lomax, \& Whitehead (1996) wrote that teachers' questions should emerge from a "discomfort of knowing we are not acting in 
accordance with our values and beliefs" (p. 47). A practitioner should note "discrepancies" between the class outcomes and the intended values and aims (Altrichter, Posch, and Somekh, 2008). Argyris and Schön (1974) wrote about this as a discrepancy between "espoused theory" and "theory in use." Out of this reflective awareness, the practitioner's critical aim for action research is professional growth (Sagor, 2000; Schwalbach, 2003; Stringer, 2004).

It is important to note that this narrow conception does not mean we see research as being solely for the benefit of the practitioner. Rather, because the practitioner is an educator who influences students, their growth is seen as more widely beneficial. Dosemagen \& Schwalbach (2019) note that "Data gathered as part of the action research process documents not only the transformation of the teacher's practice, but also the potential transformation of student learning" (p. 178). Carr and Kemmis (1986) specify that the self-reflective inquiry driving action research studies are undertaken by practitioners with specific aims - to "improve the rationality and justice of their own practices, their understanding of these practices, and the situation in which the practices are carried out" (p. 162). Thus, the aim of educational action research is professional and personal growth, but this growth is in service of wider social benefit. To summarize, a valid educational action research study will implement a high quality and relevant curriculum that emerges from the practitioner's awareness of "discrepancies" between aims and outcomes, and will lead to improved practice for the benefit of future students. Broader conception of validity: Action research for empowerment 
Action research that is conducted in community rather than educational settings typically has a broader conception of validity with more emphasis on social justice outcomes. Like educational action research, these studies typically do not seek generalizability, nor contribution to theory; they should, according to Kemmis (2010) aim for "the contribution of their action to history" (p. 425). Heydenrych (2001) argues that reflection and improved performance should not be the only end goals; instead, action research should critically examine practices in education that tend to be universally accepted and justified, and problematize them. To be "emancipatory," action research promotes critical consciousness and political action (Grundy, 1987). Significantly for this study, "it teaches people to take charge of change processes on an ongoing basis" (Lune \& Berg, 2016, p. 142). This implies that capacity-building in service of political efficacy is part of what makes action research studies valid. As Stringer (2008) writes, action research should engage people's sense of agency and their view of themselves-it "seeks to enhance people's feelings of competence and worth, engaging them in processes that provide an affirmation of themselves, their friends, their families, and their communities" (p. 32). In short, a study should enable participants to "maintain a constructive vision of themselves, anchoring them in a productive perspective of their worlds and enabling them to work easily and comfortably with those around them" (Stringer, 2008, p. 33). Stringer's criteria are quite relevant to this study of civic engagement education. To be valid, we could say that this study should seek to develop in students both a "constructive vision of themselves" and a "productive perspective of their worlds." This view of self and world could also be framed as civic agency. 
Though not widely studied, another perspective on validity relating to this broader conception is psychopolitical validity. Developed within Community Psychology, psychopolitical validity refers to the extent to which studies integrate knowledge about and experiences of oppression, and promote psychological and political liberation (Prilleltensky \& Fox, 2007; Prilleltensky \& Prilleltensky, 2006). This relates to civic engagement education because, to be valid, studies on this topic should acknowledge the impact of social oppression on students' civic behavior, and teach relevant approaches for students to claim an empowered stance within the civic world.

\section{Validity of this study}

In sum, for a study of this kind to be valid, it will be aligned with the aims of empowerment and capacity building (Stringer, 2008). A valid study will "find ways of enabling" participants to "formulate more productive understandings of their own situation" (Efron \& Ravid, 2019, p. 32). In this case, these "more productive understandings" will be the perspectives and attitudes underlying civic agency.

The "discrepancy" I seek to address here is the sense from my practice that while students have adopted more civically engaged attitudes and behaviors, they have not had the opportunity to address more entrenched patterns that have kept them from engaging. I have thought the curriculum was overly focused on future aspirations and did not provide adequate strategies for addressing disengagement connected to the past. Based on the considerations discussed above, this study's validity lies in four aspects of its design: (1) the curriculum is grounded in political and educational theories, (2) one aim is to improve my teaching practice, (3) the larger aim is to help students develop increased civic agency 
and resilience given the impact of social oppression on students' civic behavior, and (4) the core narrative sequence is designed to teach students a process by which to "formulate more productive understandings of their own situation" (Efron \& Ravid, 2019, p. 32) and move toward a "constructive vision of themselves" (Stringer, 2008, p. 33). This understanding of the validity of the study is drawn from both strands of action research, and from the concept of psychopolitical validity.

\section{Limitations}

Several limitations have impacted this study. First, the total study population of 29 students was small, and the inclusion of students of color was not representative of the overall student body. Further study is needed to assess how this model impacts diverse urban populations of undergraduates. The study design took this into account, providing thick data and referring to individuals by name (pseudonym) to give as much insight into particular students' processes as possible. The function of this study to provide insight into the model's usefulness is still served by a small study population. Second, as both researcher and instructor, I was limited in my ability to see how my own assumptions were embedded in the process. I mitigated this through keeping a research journal in which I responded critically to my own ideas, taking the position of a skeptical challenger. I also discussed the model and course design with colleagues in order to gain additional perspective and learn from their questions.

Finally, the study is limited in its usability in three ways. First, action research does not lend itself to simple comparison to other contexts. Second, not all course curricula lend themselves to the inclusion of personal narratives. And finally, not all 
instructors will want to bring re-engagement and healing goals into their curricula. It is important to see this study as one way of framing civic engagement that elicits a certain set of possibilities for curricular approaches. It is relevant to practitioners and institutions that view healing and re-engagement as part of their educational mandate. This study is intended as a first step in process of applying the Holistic Civic Engagement Education model to various contexts and using it to develop not only variations on the narrative sequence, but other types of assignments.

\section{Positionality of the Researcher}

My own identity, background, and worldview greatly shaped this study. I acknowledge this positionality as part of presenting the study. My own interests and perspectives shaped what I found worthy of investigation, and how I interpreted the data students generated. Three aspects of my worldview were most relevant to this study-a value of holism and healing, an emphasis on education as a leverage point, and an aim of improving our collective use of power.

First, I learned a personal practice called clearing taught by the Last Mask Center. The three key components of clearing - identifying an aspect of the self that remains stuck in a past struggle, maintaining a compassionate presence and engaging that self without identifying with it, and meeting a need of that self to integrate its gifts - are the components of the core narrative assignment. After putting this practice to use in my life, I trained to teach it, and now have done so, through an online class, to over 600 people.

Second, even as I chose a $\mathrm{PhD}$ program in a school of government, I have always seen education as the key leverage point at which I wanted to work. I have long been 
interested in why people act as they do and in what processes encourage growth. Nearly every job I have held since childhood has been as an educator. My Masters degree is in Education. My interest in Public Administration is an interest in the questions of process and relationship embedded in the questions of how we govern ourselves. I want to know what kinds of education allow people to make wise decisions as citizens.

Third, I have a holistic perspective on governance that is embedded in this study. My interest in civic engagement comes from the driving question, "How do we make wise collective decisions?" I hold the worldview that humans have a sacred nature, that this nature is obstructed by individual and collective trauma, and that the primary change needed for a sustainable future and democratic governance is to access the innate wisdom and care that is hidden under this obstruction. Through healing, a capacity for love is strengthened, and when this love is put into action, authentic power can fuel sustainable change. Combining these three world views yields the impetus for this dissertation: I want to effectively educate and heal so we can use power well together.

In addition to these three world views, my identity has also shaped this work. I am an upper middle-class white woman, and the third generation in my family to earn a doctoral degree. I see the world and my students through these lenses. I am interested in learning about the experiences of students in urban public universities, and developing as an educator who can teach civic engagement effectively. However, my own experience of college was at a private institution. Challenges that some students face because they hold marginalized identities are not challenges I have personally faced. As a white person interested in learning from Indigenous knowledge, I am aware that much of this 
knowledge has been held by communities despite violent attempts over centuries to erase it. Access to Indigenous knowledge is an invaluable gift, and one that can only be offered by those who hold it.

Because this thesis deals with engagement and service, it is also relevant to include that I am the third generation in my family to choose a public service orientation for my career. One of my grandfathers worked for the federal government, and the other for the University of Minnesota as a journalism professor who wrote about the social responsibility of the press (see Gerald, 1963). My parents worked for various nonprofits and the University of California. My orientation toward education, and the various forms of privilege I hold, form an important context for this project.

Emergence of the theory from life experience

The theory that this dissertation proposes and assesses arises from the question "What might civic engagement education look like if undergraduate course design were based on a holistic understanding of both civic engagement and the competencies that enable it?" This question emerges out of two life experiences: The first was participating in several personally meaningful public engagement efforts, and seeing them each fall apart due, by my analysis, to crippling holes in the holistic competencies of group members, including myself. The second was experiencing as a graduate student the benefits of some elements of holism integrated into my Master's field of Education, but finding it missing in my current "home field" of Public Administration. I became invested in the question of how the competency holes I had experienced could be in future be partly prevented though holistic higher education courses in all fields that address civic 
goals, not just in Education. While current practices in civic education in universities sometimes accept these aims, we have very few models that benefit from a fourdimensional understanding, and therefore miss key opportunities to prepare students for civic life. 


\section{Chapter Four: Results}

This chapter summarizes the findings of the application of the Model, responding to two questions: How does writing a sequence of engagement/service personal narratives impact undergraduates' capacity for holistic civic engagement? and, what learning did students demonstrate in relation to each of the Holistic Civic Engagement (HCE) curriculum components? The chapter presents the results from the first course, Introduction to Civic Engagement, followed by results from the second course, Fundamentals of Public Service. I briefly review each component of the courses and its specific role within the curriculum. Then I discuss the data generated from implementing that component, and summarize what I learned about how that curricular component served students' learning.

In summary, the key findings were that the HCE courses impacted students and did help them develop holistic competencies that could support their future engagement. In particular, students overall showed growth in their capacity to: comprehend the importance of civic engagement in a democracy, value their own political voice, trust collective endeavors, track and discern the feelings and needs underlying their public behavior, empathetically respond to past experiences of disengagement, commit to democratic values such as inclusion and deliberation, and orient toward growth and process. The learning aims that were not met were: discernment of personal civic vision and discernment of personal needs students must address in order to sustain their engagement and service. 


\section{Course One: Introduction to Civic Engagement}

The first of the two courses in the study was PA 311: Introduction to Civic Engagement. This course meets requirements for the Civic Leadership Minor, but also for several of the University's distribution requirements. Students in the course were predominantly social science majors, but we also had majors in Business, Biology and Chemistry. There were 19 students in the course, which was taught during the Fall 2018 term on Tuesdays and Thursdays at noon. I have taught this course approximately ten times at PSU. Though I redesigned it each time I taught it, the HCE lens resulted in significant revisions, especially the addition of a sequence of three writing assignments intended to build HCE competencies. In total, I analyzed the student work elicited by seven curricular components:

1. Pre-Assessment

2. Narrative Part One (Dis/Engagement Narrative)

3. Narrative Part Two (Contextualization of Disengagement: Letter to Self)

4. Narrative Part Three (Civic Vision Narrative)

5. Dear Jane notes (open-ended daily assessment)

6. Self-Evaluation

\section{Reflection on Class Community}

In the following sections, I present findings from the pre-assessment, the three narrative assignments, the self-evaluations, and the reflections on the class community. Findings from Dear Jane notes and the in-class activities are woven into the other findings where relevant. 


\section{I.Pre-Assessment: What is Civic Engagement?}

The questions were:

1. What are you bringing to class? [thoughts, feelings, ideas, concerns]

2. What makes a person civically engaged? [What actions, thoughts or feelings?]

3. How does a person know they are effective in their civic engagement?

\section{Results}

Several themes emerged from these Free Write prompts. First, this group showed an overall interest in and enthusiasm for the topic of the course while also admitting to various forms of anxiety. Second, their reported conception of civic engagement was skewed toward a generalized and apolitical understanding of it as receptivity, responsiveness and caring. Finally, and relatedly, their conception of efficacy of engagement was largely nonnormative as well; efficacy was framed as whatever outcome would garner the approval of the community. Only three students mentioned equity or justice as goals of civic engagement, and one person briefly referred to policy change as an indicator of effective engagement.

What are you bringing to class?

Many students expressed excitement or enthusiasm, but several students varied from this pattern. Ten students mentioned excitement or appreciation at being back in school. Several referred to the material as interesting and signaled their openness to learning. One student wrote that she had minimal understanding of civic engagement but a passion for social justice. In interpreting this overall enthusiasm, it is important to be 
aware of the effect that grading may have had. Though I explicitly asked for honesty, students were aware that their names were connected to their responses.

In addition to the theme of openness and enthusiasm, five students shared feelings of overwhelm or anxiety, and one student shared skepticism that the class could be impactful. Several of these people referred to the transition to PSU as causing nerves or exhaustion. Two students admitted to anxiety about the course as they did not know what it would entail and it was outside of their previous experience. Finally, one student, Ben, ${ }^{3}$ a Biology major, acknowledged that the class was part of a requirement, writing: "I'm trying to keep an open mind but I still kinda wish I was wrist deep in a dead animal doing a necroscopy." Students' responses to this prompt help form a baseline for their attitude toward the course and its content.

\section{What makes a person civically engaged?}

Student responses to the prompt "What makes a person civically engaged?" fell into three categories: Responsiveness, passion, and informed-ness. There was also a cluster of students who responded that they did not know what civic engagement was.

The most common response, given by eight students, was that a civically engaged person is receptive and responsive. These students described engaged people as being "involved through listening to other people," through asking questions, by being aware of the environment around them, and by being "a good reader of surroundings." Clara went somewhat further to add that a civically engaged person is "Someone who is involved in their community—who is aware of how their actions affect those around them, and also

\footnotetext{
${ }^{3}$ All names used in the dissertation are pseudonyms.
} 
works toward the betterment of said community." Two people used the word "care" and one student added that an engaged person would "feel for a community." Overall, students had a strong response that civic engagement involves receptivity to others and caring responsiveness.

Half as many students — four-wrote that a civically engaged person has goals or visions. Rebecca wrote that this person would "want to see change, and their actions reflect that." Someone else noted that passion is needed, not just as an expression of care for others, but as necessary in order to reach goals. A third student wrote that an engaged person would be a "bonfire of motivation," and a fourth wrote that this person would get others involved. It is noteworthy that this smaller cluster of students added a sense of individualized purposefulness to their definition; this group of respondents included intentionality and mobilization of others along with the more commonly noted general ethic of community responsiveness.

Only three students named specific behaviors that comprise civic engagement. Two mentioned voting, one of whom also included "holding office" and "attending town hall meetings." The third student in this category simply named that a civically engaged person is "informed." One person gave a more unusual definition, writing that civic engagement is about "being present physically, emotionally, and often spiritually." This indicates that, while not a majority perspective by any means, I did have at least one student who was already thinking in holistic terms.

Three students wrote they were not fully able to describe a civically engaged person. Ben wrote that he was "Not sure what really makes someone a community leader 
or an activist, but I think you could be those things without being civically engaged." With this comment, Ben indicated a sense that leadership would only be civic leadership if it came from the aims of social improvement or stemmed from legitimate authority to speak for a group. Carla wrote "Couldn’t really tell you" but suggested, "Being friendly and helping clean up."

How does a person know they are effective in their civic engagement?

Corresponding to the pattern of conceiving of civic engagement as responsiveness, the largest number of answers about effectiveness fell under the theme of "receiving feedback from others." Students wrote that an effectively engaged person would observe that "peers would agree with their ideas." They would see that conversations would continue because others would show receptivity with their body language, they would see passion and willingness to help emerging in others, they would be thanked, or they would recognize the change they helped cause in the form of a smile, a policy change, or a movement. Two students mentioned that effectiveness could be ascertained based on seeing change in the world. Two other students specifically referred to improved equity as a marker of effective engagement.

The pattern that was revealed by this assessment was students' value and apparent commitment to collaborative, consensual leadership. They seemed to value consultation with community and representativeness in leadership highly. The asset here is that they are likely to be skeptical of domineering leaders. The challenge with this understanding of civic engagement is that without policy aims, it is more challenging to formulate strategy. All in all, it seems likely that these responses simply revealed a lack of 
experience. Without a clear conception of civic engagement, what makes it ethical, and what its purpose is within a democratic society, students likely responded with a general definition that seemed best to them based on their knowledge of representative government: civic engagement means acting on behalf of shared interest or shared benefit. It means acting from "passion", an internal driver generally associated more with social aims than with self-interestedness. It is notable that even when prompted to supply observable traits, students did not seem to know what actions actually comprise civic engagement.

\section{Group Pre-Assessment}

In response to the class-wide prompt "What does civic engagement look like?" students shared the following responses: Awareness of environment and community, effective and efficient, association with community organizations, betterment of the world around them, brave and working out of one's comfort zone, community-minded, caring and involved in the community around them, a little sacrificial and selfless, openminded and aware there is no one truth, inclusive, informed and reads about both sides of an issue, passionate and able to take action based on commitment to get heard, teamoriented and committed to community processes. Of the 12 responses, nine have a reference to the importance of looking outside oneself — including others, referring to their perspectives, and embodying a generalized openness. Association would also emerge from a group-orientation. At this point in the term, it did not appear that I needed to teach this group to care about others. It seemed that I needed to teach them how to put 
this care about others into action. As much as I prompted the group with follow-up questions like "what does it look like? What does it sound like?" students at this point could speak only to those 12 themes, and remarkably little to strategy, organization, leadership, policy goals, or wielding influence upon the institutions that shape their lives. Framing the pre-assessment results

It is useful to briefly frame these responses in terms of the civic engagement frameworks presented in Chapter One. If we can understand students' initial beliefs about civic engagement in terms of this literature, it can help us see where there might be potential for growth. Students' initial perspectives on civic engagement reflected a civic republican ethos on one hand, but stopped short of it on another. On one hand, students seemed to see civic engagement as involving "willingness to put the common good above [their] private interests" (Sandel, 1996, p. 26). They emphasized how important it was to elicit community input before making decisions. Furthermore, students emphasized key affective components of civic republican participation such as care and investment.

Where students stopped short of embracing civic republicanism was in their avoidance of the topic of deliberation and the importance of policy making as a goal of civic engagement. In their strong value of receptivity and responsiveness, it seemed that students believed that a shared sense of the common good existed, and just needed to be elicited. They did not seem to arrive in class with a belief that citizens must actively create this shared sense through bringing their perspectives into political forums. Additionally, students did not seem initially to see it as their right or responsibility to shape policy, and they did not seem to see civic engagement as inclusive of the critical 
citizenship criterion of action toward social justice. Finally, in emphasizing personal passion, students implied they held a more individualized (rather than collective action) model of civic change.

\section{Implications of pre-assessment results}

Given this consideration of pre-assessment data in terms of civic engagement frameworks, it seemed that students arrived in class with an ethos of care and duty, but that they did not have a strong sense of empowerment to shape policy based on their values. It appeared there was room for growth in students' sense of themselves as active (not just responsive), empowered (capable of entering the political arena to deliberate), and strategic (mindful of policy outcomes) citizens.

Considering these findings in the context of the HCEE Model, it seemed that there was potential for important growth in capacity. It appeared students had not had the opportunity to clarify their civic visions (East), nor consider how civic engagement behavior could be conceived of as using one's personal gifts in service of a vision (North). There was evidence that students valued relating to others (South), though not necessarily that one's relationship to oneself was relevant (South). We did see evidence of students valuing compassionate discernment in civic engagement (West). The course would need to build on these assets and help students move further toward capacity for civic empowerment and agency.

The re-engagement tool, implemented through the core narrative sequence, was intended to facilitate this deeper sense of empowerment. The premise of the tool is that growth in the capacity to wield civic power in service of vision (North) can be developed 
through a holistic learning process. The following section discusses how students responded to the promptings of the re-engagement tool, laying out the results from analysis of the narrative essays for Course One.

\section{Narrative Part One (Dis/Engagement Baseline Narrative)}

The first writing assignment of the term was part one of the three-part narrative writing assignment. This short first assignment (Appendix B) asked students to respond to two prompts: What is one experience of engagement that you have had in your life? And What are two experiences of disengagement you have had in your life? The subprompts elicited three topics for elaboration-description of the context of the experiences, a consideration of what values the student was expressing as they had the experiences, and a paragraph-length reflection on what made the experience engaging or disengaging. This assignment did not include the word "civic" along with the prompts about engagement in order to cast a wide net in eliciting students' experiences. The civic implications of students' engagement and disengagement would be brought out through class discussions and further assignments.

Assigned in Week Three, this first narrative was not primarily intended to help students connect to the readings. However, two course components were intended, less directly, to contribute to students' capacity to respond to this assignment. The first was a concerted effort to establish an initial sense of community in the class. Each class period was begun with an opening circle which included names, a very brief check-in from each person (e.g. "something you observed during the week that seemed to encourage your participation"), and a time for announcements (e.g. "the campus food bank is looking for 
volunteers" or "the soccer team has a match"). Additionally, most class periods included small group tasks designed to elicit collaboration over competition, and Week One included a civically-themed icebreaker. The second curricular component intended to support this first narrative was the course content on power and privilege in civic engagement. Students read an academic article on inequality and trust in civic engagement, King's “Letter from Birmingham Jail," and Armstrong's “An Okanagan Worldview of Society," and watched two videos about race and civic engagement (See Appendix A, Week Two). Additionally, most of one class period was devoted to an experiential exercise meant to allow students to reflect on how a sense of "knowing the rules of engagement" (privilege) contributes to a sense of inclusion in communities.

These two curricular components-community building and discussing issues of privilege —were meant to support students' reflective narratives. The community building was intended to model a sense of interpersonal care that students could then reference in their own relating to and reflecting upon themselves. The topics around privilege were intended to help establish a compassionate baseline in the course by way of affirming that individual disengagement often results from systemic factors, and should not be seen as a personal failing. These components would ideally help students approach Narrative Part One with more comfort and honesty. Their honesty would serve the depth of their writing, and could make the implementation of the re-engagement tool more meaningful.

\section{Results}

To summarize, the learning outcomes for the visual exercise and paper were:

1. Students will bring awareness to the factors that lead them to feel engaged. 
2. Students will bring awareness to the factors that lead them to feel disengaged.

Students seemed to take both the in-class and essay components of this assignment seriously. The in-class portion involved students individually mapping a brainstorm around their engaging and disengaging experiences, following a suggested format I modeled. There was quiet and apparent focus in the room during the exercise, and the questions I received indicated that students were grappling with the questions of when and how they had shown up or shut down in their lives. Two students commented to me after class that they enjoyed considering their own engagement and disengagement. In Dear Jane notes from class that day, several students commented generally that they had come to realizations about their patterns of engagement and disengagement from doing this exercise. The following section describes the analysis of the narrative essays. Experiences of engagement in Narrative Part One

Based on their relatively rich description of experiences of engagement and the internal impact of these experiences, all students demonstrated awareness of their engaging experiences. Many students exceeded my standard by not only describing an example, but by naming qualities of what it felt like to be engaged. While the first question I had was whether students could demonstrate awareness about their engagement, the more substantive question for analysis was how these students framed and defined "engagement." This is a significant question to pose of these data because it could reveal more about the baseline knowledge of the group. By determining what patterns existed in students' past experiences, I could better design the next phase of the assignment (the goal of which would be to practice a technique for changing habits of 
disengagement). To identify patterns, I re-read the papers and noted the themes that came up in each. Three class-wide themes emerged through analyzing students' experiences of engagement:

\begin{tabular}{|l|}
\hline \multicolumn{1}{|c|}{ Themes from Narrative, Part 1: Engaging Experiences } \\
\hline 1. Nearly all students discussed engagement as a result of moving through a challenge. \\
Engagement was often framed as a feeling of contribution or investment that was earned \\
through struggle. \\
2. Often, the challenge students had to move through was connected to race, gender, religion, or \\
age limitations. \\
3. Often, what allowed the students' challenge to evolve into an engaging experience was some \\
kind of supportive connection with other people.
\end{tabular}

\section{Nearly all students discussed engagement as a result of moving through a challenge. Engagement was often framed as a feeling of contribution or investment that was earned through struggle.}

By the time they composed their essays, most students had come to frame engagement as something won through struggle. Whether they already had this understanding, or whether it came through the process of brainstorming and writing, I unfortunately cannot know. It is nonetheless a substantial finding that approximately $90 \%$ of the papers framed engagement as something gained through meeting a challenge, even though neither class discussion nor the assignment description suggested that framing. One example of this came from Rebecca, who wrote of her engaging experience speaking about suicide prevention with an Oregon member of Congress: "This experience came from pain at first." She continued,

I started volunteering because I have dealt with depression and suicidal ideation for years and knew how hard it was dealing with that pain alone. Having the 
opportunity to speak with Oregon congressmen was the most engaging part of my experience. I was able to explain to them about the problems that Oregon was facing that as a teen that was facing some of those issues myself [sic]. This engaging experience is my motivation behind going to school and getting a degree. I think that this moment will always serve as a reminder that we as individuals can make a difference.

Similarly, Carlos wrote of his confronting challenges to transfer to PSU: "My transition and transfer to Portland State was engaging in my education because I struggled to continue with it." Additionally, Ben wrote, "I think that disengaging experiences, to a certain extent, often come from previously engaging experiences where there was trust lost or expectations not met." Finally, Karen referred to moving from feeling like an "outcast" at the university to pride at her decision to get involved in a club. This theme suggests that this assignment was likely effective in beginning to guide students toward a broader understanding that their challenges, risks, and discomfort could hold a larger significance and become valued learning experiences. This understanding forms part of the HCEE competency, Trust.

\section{Often, the challenge students had to move through was connected to race, gender, religious, or age limitations.}

The second theme that emerged was that many students mentioned systemic issues like race and gender as part of what caused the challenge that eventually led to engagement. Though, again, I did not prompt students to raise these issues, many did, and many stated explicitly that mentioning context was necessary in order for them to speak 
to their eventual engagement. Two students mentioned gender constraints, one person mentioned race (four if we include the whole class), two people religion, one older age, and one mental illness stigma.

Josue's paper gave a rich example of how students brought in positionality as context for engagement. Josue used his opening paragraph to describe his experience being Mexican-American in a small town. He wrote about how he developed a sense of not being cared about in school, and became a class clown until one teacher brought up this pattern in a kind way and opened a dialogue. From there, he experienced a "huge change in attitude towards school." He felt "that I wanted to be there and wanted to learn, and I became so passionate it was amazing to me what one teacher could do. Each time I stepped into her class I felt engaged to learn and to finally start being a student like I wanted to be my whole life; it was [a] breath of fresh air." Carla's assignment, similarly, began with gender, and her sense of being pressured to act and dress in feminine ways. Her engagement came from finding an extracurricular context where she felt relief from this. This was an experience of "being myself, the happy, carefree, content with my body self." She continued, "I felt so bold and empowered. Even though I didn't look like the other girls, no one made comments about it, they just let me be on a team together. I felt like I belonged. It also lit a spark inside me, I started working even harder to reach the team's goals." This led Carla to the core of what was engaging - multiple successes as part of the team, a leadership role, and representing the girls at board meetings.

\section{Often, what allowed the students' challenge to evolve into an engaging experience was some kind of supportive connection with other people.}


The third theme that emerged as students wrote about engagement was the importance of supportive relationships in converting challenge to engagement. For Josue, as I quoted above, his teacher was key. For Jesse, a similar interaction with a caring teacher was meaningful: "Their insights gave me the ideas and support that motivated me and left me imagining a future much greater for myself than I thought possible." Karen, like Carla, who had found a sense of belonging on a team, found inclusion through an extracurricular activity despite her age: "I never expected to be chosen for a leadership position, so when I was it felt like I really belonged in the club and made me extremely motivated to do the best job possible. I felt proud that I wasn't some sort of outcast due to my age." Ayah's engagement came through a collaborative project that addressed the gender issues she experienced growing up in the Middle East. She wrote that "it was very inspiring to work with others on this cause because breast cancer was dominant mostly in women." For her, it was the collaboration that validated the importance of women's rights, which she was struggling to assert in her family. Relationships with peer groups and teachers were the primary way that students discussed coming into engagement by way of difficulty.

In sum, students' responses to this assignment prompt suggest that the assignment is an effective means for eliciting awareness about personal engagement. Students' capacity to construct this knowledge is significant for the study. It suggests that building this awareness is a useful first step in HCEE. Because a key part of the adult learning process is reflecting on experience (Kolb, 1980), this reflection assignment likely 
contributed to students' readiness to generalize and theorize about engagement beyond their own.

\section{Experiences of disengagement in Narrative Part One}

After discussing an instance of engagement, I had prompted students to describe two disengaging experiences. The aim of this component of the assignment was to set the foundation for critical insight that could potentially allow students to note ways they might have lost a sense of agency. With this insight, and with a commitment to their visions, they could potentially stay engaged rather than shutting down in certain areas of their civic lives. To analyze this component of the assignment, I read the essays twiceonce to identify themes, and again to check whether those themes left anything out. My aim was to first simply determine whether students had met the criteria for demonstrating awareness. The second aim was to shed light on the kinds of contexts in which these students had experienced disengagement, and on how they tended to frame and make sense of these experiences.

All students were able to meet the learning outcome for this portion of the assignment - to describe, ideally richly, their experiences of disengagement. Many students went beyond the minimum to reflect on what might cause disengagement in society. This suggests that this component of the assignment was effective in both laying the groundwork for understanding civic engagement theories, as well as preparing students to gain skills to reconcile with past disengagement and reduce the impact on their civic agency. In answering the second, broader, question, three themes emerged in analyzing how students wrote about disengagement: 


\section{Themes from Narrative, Part 1: Disengaging Experiences}

1. Students acknowledged the seriousness of past experiences in shaping their later behavior.

2. Students noted that disengagement often was the result of not feeling valued as a person.

3. Some students named ways that disengaging experiences taught clarity and commitment.
}

\section{Students acknowledged the seriousness of past experiences in shaping their later behavior.}

The first theme I identified was that many students were clear that a disengaging experience had distinctly changed their behavior. This finding was significant because it indicated that identifying and working through experiences of disengagement could indeed have potential to shape patterns of behavior, possibly including civic engagement behavior. Students' clarity about this came in the form of statements like that of Rebecca, who experienced being stigmatized for mental illness: "The first time I remember this happening changed the way I opened to people for the rest of my life so far." Carlos wrote of his pivotal experience when his mother admitted that she did not believe him capable of finishing school. Her comment "really affected my motivation to pursue more schooling along with giving me a sour taste about school." Ayah wrote that after trying unsuccessfully to intervene in the arrangement of her younger sister's marriage, she was "repelled" from future efforts. Carla described a shift from feeling competent and comfortable to feeling "trapped in my own body." Finally, for Ben, the shift was from feeling at home in a church community to feeling that:

Friendship and personal growth through the church became impossible...There was no benefit of me engaging with those people or the church as a whole...All of 
the good things that I like[d] about the church had now been tainted by the fact that I fundamentally couldn't trust anyone.

In addition to these five students, three others alluded to a sense that they had been changed forever by a disengaging event, even though the assignment did not elicit this.

Of their own accord, eight out of thirteen students named that they had been permanently (though not all of them fundamentally) changed.

\section{Students noted that disengagement often was the result of not feeling valued as a person.}

Eight out of thirteen students connected disengagement to a feeling of being disregarded or undervalued. This ranged from outright racism—such as when Josue was told to drop out of school if he couldn't behave, since "We always need Mexicans to pick watermelons"- to more individualized cases, as when Clara was chastised and called "unprofessional" when she needed to take a day off work for a family crisis. For Stephanie, it was the feeling of a lack of empathy:

It is frustrating when I don't feel someone has bothered to try to understand my perspective. Feeling that way is really disengaging for me; once I begin to feel that way I don't see much point in carrying on the conversation, so I shut myself off to protect myself emotionally [punctuation added].

Carla was told by a youth group leader that the leader was not sure she could love a child who was gay. Ayah was told flat out that "women are destined for marriage, regardless of age or personal choice." Whether it took the form of a broad social bias applied to the student, of whether they simply didn't feel seen and valued personally, when students 
were prompted to discuss their disengagement, the majority of them responded with instances of feeling their humanity was diminished or disregarded.

For the five students who responded differently, their disengagement occurred as a result of: being accused of something they didn't do (2), being told their political views were invalid (2), becoming too overwhelmed to engage (2), and being disappointed when a group became dominated by one person (1).

\section{Some students explored ways that disengaging experiences taught clarity and commitment.}

The third theme was that students wrote about what they learned from disengaging instances even though this was not part of the prompt. This suggests they may have wanted to repair a sense of vulnerability by affirming that they were able to bounce back or "make the most of" their hardship. It may also suggest an openness or predisposition to the key learning theme of trust in the democratic process. Part of trusting the process is being willing to risk, fail, experience and learn because one trusts that difficulty yields learning which in turn serves one's larger goals.

Five students brought up their learning. Some, like Josh, referred to the essay itself as the source of insight, while others were more general. Josh discussed his disengagement as stemming from a desire to prove himself and perform for approval. $\mathrm{He}$ wrote that when he started this assignment, "Yet again, I used the intentions to impress others and to prove myself as a talented writer to motivate me." Josh realized that this extrinsic orientation was "not real." Instead, "What I really want is to share my truth. I want to learn. I want to evolve. It was with these intentions that I was able to finish this 
paper...Intentionality is the seed from which all ensuing actions and consequences grow.” Josh realized that his intention to learn rather than to perform was the seed of his engagement. Josh, the student who defined civic engagement as "showing up" emotionally and spiritually in his pre-assessment, was a unique example. Still, his capacity to draw this important learning from the assignment raises the questionsthough they are beyond our scope here—of how background knowledge impacts students' HCEE growth, and if the curriculum should be modified if students do not have significant background.

Three other students mentioned that the writing process had taught them something. Rebecca was direct: “As I reflect, I notice that no matter the case you can learn something...Most of my disengaging situations have a silver lining and turn to an engaging experience." For Rebecca, it was dropping out of school that drove her to value and commit to her education at a new level. Karen wrote that after describing her engagement and disengagement, she felt a new level of responsibility and commitment: I think that I definitely need to find areas and 'associations' that truly interest me, I'm knowledgeable in, and enjoy...Instead of making excuses regarding why not to try something, I will start finding reasons of why I should. It is nice to feel like a part of a community and a group that shares your same interests and I can realize many benefits by doing so.

Karen's disengagement had come from overwhelm about the state of animal rights and from finding a group dominated by one person. In discussing her engaging experience alongside these, she seemed to reach the conclusion unaided that she could bring the 
sense of inclusion and belongingness she felt in her student group, to other groups in future.

Ben added some fruitful theorizing to his paper. In reflecting on his own experience, he naturally reached to generalize. In doing so, he named a core theme of the course, and of civic engagement, trust:

Trust is the big takeaway for me in this exercise...I think that social trust is the fundamental core of building social capital. In writing this paper it has allowed me to look inward and realize that letting other people know that I'm someone they can trust might lead to bigger and better things.

It was significant that Ben, who was lukewarm about the course's topic, expressed this motivation to build trust in society based on his realization that trust created wide social benefit. It is also significant that he arrived on his own to the importance of becoming someone that others could trust.

\section{Summary}

The combination of students seeing the gravity and impact of these disengaging experiences, plus their willingness to learn from them, was significant, and it set the stage for the next pieces of the assignment. Additionally, the theme that disengagement came from not being seen and heard was relevant for the next piece of the assignment, which was based on the theory that transforming disengagement requires empathetic engagement with the self. 


\section{Implications of findings from Narrative Part One}

Narrative Part One was a baseline assignment meant to create the foundation for implementing the re-engagement tool in Part Two. This means that the results here do not yet speak to the efficacy of the tool, but in looking at how students responded to a very general eliciting of their engaging and disengaging experiences, we can assess how accurate and appropriate the premises of the tool and Model are. We can begin to assess the tool's appropriateness as a means of engaging students in a relevant and constructive process of reflection.

First, one finding spoke directly to the relevance of the tool: students explicitly acknowledged the seriousness of past experiences in shaping their later behavior. This finding suggested that what occurred in students' pasts was indeed relevant to their present sense of engagement and agency. It suggested that it would be fruitful to teach students a way to hold a new, more empowered orientation to these past experiences. It would be useful to teach them that, when they are ready, they have some ability to come to hold these experiences as challenges that allowed them to learn and grow, rather than simply to collect them as evidence of their incapacity.

Second, most students discussed clearer and more committed engagement as a result of moving through a challenge or struggle, and that this emergence was often a result of relating and connecting with a supportive person. This aligns with the broad HCEE conception of engagement as a process and movement through the directions. It also aligns directly with the tool's underlying logic: by bringing a new, compassionate awareness to a "self" that has felt disengaged, one can forge a new relationship to that 
experience and go forward with increased capacity. The tool guides students to become, for themselves, that supportive person who brings empathy and values them as people, and thus allows for a more constructive orientation to their struggle.

Third, the finding that many students' engagement struggle related to their identity indicates the importance of Critical Insight as a competency in the East of the tool. It is important to teach students to consider the systemic influences upon their own and others' civic behavior. Without developing the habit of mind to look for systemic influences, students could draw inaccurate conclusions about individual capacity. Teaching Critical Insight does not mean teaching students that they are mere victims of systemic factors. The aim of the HCEE curriculum is to instill Critical Insight as a habit of mind so that students can more astutely recognize and respond to obstacles to their engagement. Readings and discussions would need to actively teach this habit.

The following analysis relays the results from Narrative Part Two, in which the reengagement tool was directly introduced. The tool's relevance was indicated by what we found from Narrative Part One - the significant legacy of past disengagement, the transformative impact of a key compassionate relationship, and the importance of responding critically to disengagement that was connected to bias.

\section{Narrative Part Two: Contextualization of Disengagement}

Narrative Part Two was assigned in Week Seven and introduced students to the reengagement tool. The assignment (Appendix C) asked students to select an experience that was disengaging, and write a letter to that version of themselves who felt disengaged. It then asked them to reflect on the needs and feelings this self had, referring to in-class, 
written, and video material I provided on Nonviolent Communication. Next, students were to choose three course readings or materials that would help the previous self better understand their challenging experience. Referring to these readings, students relayed why each reading was relevant to the self's experience, and what message it could relay to the self. Finally, they were asked to explain to the self what that self specifically would contribute to something the student cared about.

The learning outcomes for this assignment were:

1. Students will draw on the practice on Nonviolent Communication to empathetically analyze an experience of disengagement.

2. Students will create context for their disengagement. They will understand their reasons for disengaging and acknowledge that those reasons were valid in the past, but are no longer relevant in the present. They will practice bringing new awareness and insight to their disengagement in a way that allows them the opportunity to re-engage.

3. Students will use their commitment to their vision or values to re-engage where they had been disengaged.

4. Students will understand that political behavior - their own and others' — can be shaped by past experiences of disengagement.

In addition to the important context of Nonviolent Communication, which we read about and practiced in class, the primary curricular support for students in writing this essay came from the readings and reading discussions (See Appendix A, assignments Weeks One through Six). These included articles on participatory and deliberative democracy, and local community engagement. One example was economist Schor's 
article about freeing up time for civic participation. Another was Lappé's article on the "practical arts" of democracy, which included topics such as constructive conflict. A third example was Mandela's article about maintaining dignity while in prison. In addition to reading assignments and discussions, I endeavored to continue to build a sense of belongingness in class. We continued our opening circles and met in book club-style groups with rotating facilitation. When students made comments, in addition to responding to the substance, I would sometimes comment on an underlying strength in their reasoning or inquiry, pointing to the value of benefiting from each student's innate approach to learning. The intention was to build a sense of interdependence and respect in the course, and model a mode of relating that placed inherent value on individuals. This, along with the perspectives from the readings that encouraged the inherent right and capacity of citizens to participate, was meant to support students' ability to empathetically relate to themselves as part of utilizing the tool.

\section{Results}

In order to analyze the essays, I reread students' essays twice (a total of three times including the initial reading to give feedback). In the second reading, I recorded findings that shed any light on the two questions. I then wrote several memos to help distill themes. I then reread the essays to check the appropriateness of the themes and see if anything was missing. What emerged from this process was an understanding of students' learning as corresponding to one of three levels: 


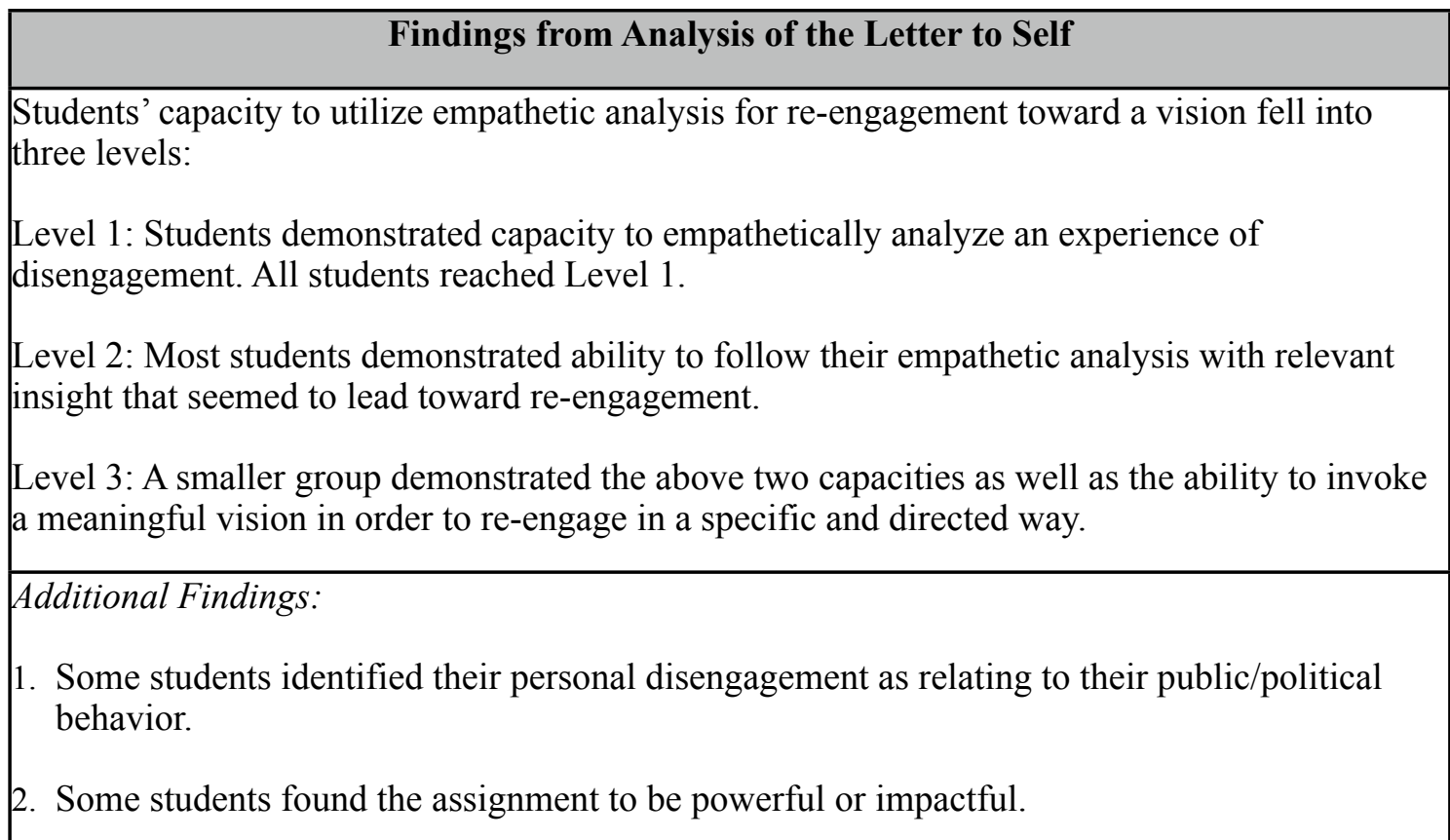

\section{Level 1: All students demonstrated capacity to apply empathetic analysis to their disengagement.}

All students in the study showed solid competency in using empathetic analysis. They typically chose specific feelings and needs that resonated with me as genuine and thought-through. One example came from Clara, who had been disengaged by perceived harshness from a boss. She wrote to that self,

If you felt ashamed and insecure because she was judging your priorities in life it's okay to have those emotions. Through this experience it would make sense to feel a sense of detachment from the institution this person works for and I'm sure it was born from the moment she walked away from you.

Like several other students, Clara referred to the feeling of disengagement—pulling back, feeling separate and uninvested. Across the board, students were able to name, and often richly describe, the feelings and needs of their disengaged earlier self. 
Josue's letter showed a particular investment in empathetic analysis. He addressed it to self who had been inaccurately and publicly accused of theft in a racialized context. He named the feelings of confusion, agitation and anger, and the needs for trust, clarity and integrity. He wrote, "you felt this sickening feeling of being ashamed and embarrassed" and "you sat there paralyzed in fear and anger...you really wanted to fight but just let it slide and played it off with a chuckle. Really it hurt so much more than that chuckle you gave off." Josue added a step after this that I did not prompt. He apologized to the previous self that he had to experience this incident. Furthermore, he continued "But most of what I'm sorry about is the way you felt disengaged for the whole rest of the year." Josue's apology speaks to the shadow that an experience like this can cast on someone's sense of engagement. Though Josue did not know how to raise and resolve the issue at the time, looking back on the experience with empathetic analysis seems to have some impact in reconciling and moving on from disengagement.

\section{Level 2: Most students demonstrated ability to follow their empathetic analysis with relevant insight that seemed to lead toward re-engagement.}

All but two students were able to build on their empathetic analysis and show evidence of re-engagement. This took many forms. Some students made a general case to the previous self that their reasons for disengaging were no longer relevant. Some of them seemed to simply want the previous self to let go of shame or blame and feel free to express naturally. Though all students used readings as required, for most of them, their own realizations and general wisdom seemed more important than perspectives resulting from the texts. 
For these students, I noted a specific mention of the desire for and need to reengage, at least in a generalized way. It seemed that these students were encouraging themselves, almost coaxing themselves, out of disengagement. For instance, Carlos addressed a disengaged self who had felt "not smart.” Referring to reading Lappé’s "Freeing the EcoMind," he wrote "When I continued the reading and came across the six inherent rights, I really questioned the way I used to think about myself in school." In an even more direct appeal to herself, Ayah wrote, "I urge you to never stop evolving, and never settle for less than you deserve. Be proud of your journey and learn from your mistakes." Though Carlos and Ayah remained general in their insights, they showed a commitment to examine their disengagement, bring empathy, and choose to go forward differently. Though their self-affirmation was general, it did seem to strengthen the foundation for their future engagement.

The majority of the students were somewhat more specific in how they invited their previous self to re-engage. Many students wrote about their hopes for their future engagement in relatively general terms such as their hope that they would lead or participate in some kind of beneficial change. Jesse was an example of this. He seemed to call on his previous self to leave disappointment behind and trust in future possibilities: "Because common ground wasn't found today, it doesn't mean it can't be in the future. Your willingness to truly understand and aid one another, is part of your process and growth as a leader in creating the very change you wish to see in our world." Implicit in Jesse's letter was his understanding that remaining disengaged had a cost. By remaining disappointed, he could not respond fully to his inner desire for change. Jesse spoke and 
wrote throughout the term about his value of social justice and his classmates noted this in their peer-assessments. Though Jesse did not write about specific policy goals, he wrote frequently about feeling inspired, and growing in his trust and commitment to the process of participation in service of justice.

Another kind of generalized re-engagement came from Rebecca and Clara, both of whom indicated that their disengagement had social, as well as personal, drawbacks. Like some other students, part of the cause of Rebecca's disengagement was a sense that others, or in fact society as a whole, did not care about an issue important to her. Responding to this, she brought a tone of reconciliation and encouragement to her letter: I know you have been angry at some many different points in life, wondering why no one is really working on this issue, therefore you must be someone that does it. Remind yourself that this is a problem for so many others and there is a chance that you can make that change in the world.

Like Jesse, Rebecca referred implicitly to the cost of remaining disengaged. She noted that even a chance at making change made the risk of engagement worthwhile. Additionally, Rebecca reminded herself that others were affected by the issue, indicating that her re-engagement could have benefit beyond herself. Clara's letter embodied a similar assumption as she invited back a previous self who had trusted in the goodness of others. Clara wrote:

Your ability to engage and connect people through believing in their 'good' is something that will always be needed in our world, and it's something you've 
done your whole life. Please come out of your head when you feel comfortablethe world is waiting.

Both Clara and Rebecca referred directly to an understanding of a key principle of the course - that sharing gifts in the world (with informed and benevolent intentions) contributes to both personal and social wellbeing.

Ben's letter showed a different kind of generalized re-engagement; he wanted to recommit to having conversation and dialogue in his life. He noted that the result of several disengaging experiences had been to pull back and avoid dialogue. In his letter, Ben incited himself to overcome this:

You have a tendency to go into conversations wanting to win, like you're on one team and the other person is your opponent. Instead of doing this you need to be the mediator of your own conversation. Look inward and ask yourself what do you need to be happy with this interaction and be honest with yourself...You're allowed to guess what the other person's needs might be and have them confirm this. This might be difficult but it will lead you to having conversations that can affect people.

In wanting to "affect people," Ben was referring to a close friend who had a disturbingly nihilistic view of society and politics. Ben's learning was significant. He recalibrated his definition of success in conversations. Rather than framing success as "winning," he came to frame success more in terms of process, understanding, and positive influence. Ben's learning both politically as well as personally relevant. He commented in class that learning empathetic analysis had allowed him to improve dynamics in his marriage. 
Of all the students in the study, Josue most directly responded to the learning goals (\#2 and \#3) of moving from empathetic analysis to setting a new intention going forward. He very clearly named the quality that the previous self embodied. As he spoke to this self and asked for a return of this quality — standing up for himself-I had the sense of Josue's insight and decision having real impact on him:

I need something back from you that I think I've lost along the way making things a little tough for me in situations like this. I really need that sense of standing up for myself to come back. Over the past couple of years I've felt as if you just let people get away with things because you want to be a nicer person but sometimes that doesn't fly, and you need that ability to argue in a clear manner back... [as opposed to the you who fought bigger kids in school]. If we got this skill of not caring what people think of us back, I feel that we would talk a lot more in class and also get more into our stretch zone when it comes to doing things and not just sitting at home and watching tv.

For Josue it was standing up for himself. For Clara it was open-heartedness. For Karen, it was hope. Though they varied in their specificity, most students in the study were successful to some degree in "inviting back" a part of themselves that they needed for engagement.

Level 3: One student demonstrated the above two capacities as well as the ability to invoke a meaningful vision in order to re-engage in a specific and directed way.

One student in the study, who was also the only student in her 30 s, was able to achieve all three levels of the assignment. In addition to empathizing and inviting back a 
disengaged previous self, Karen named a specific vision toward which her reintegrated self was called. Karen could also discern how the reintegrated qualities could be applied directly. She wrote her letter to a part of herself who had disengaged out of a sense of hopelessness as she came to learn about animal welfare issues and the degree to which animal mistreatment was tolerated by society. She wrote to herself: "You have too much to offer to just voluntarily sit on the sidelines, watching the continuation of everything you believe is morally wrong." Karen enumerated a list of what she could offer the world if she reengaged: "You are intelligent and educated, you are skilled in written and verbal communication, and these qualities could be applied to spreading awareness or organizing people in some sort of way. I also know that as a business major with a decade

of management experience, you have the ability to successfully run a business. This could be a nonprofit, such as the rescue farm you are interested in opening someday." Karen continued for another paragraph naming qualities that could allow her to have impact as an individual. She concludes her letter firmly but encouragingly, "Don't allow yourself to lose hope again." I was hoping that all students would achieve Karen's level of specificity as they invited their past selves to reintegrate. However, this suggests that time and life experience may be necessary. The next implementation of the model should aim for generalized re-engagement as a developmentally appropriate goal.

\section{Additional Finding 1: Some students connected their personal disengagement to their public/political behavior.}

As some of the above quotes indicated, much of the disengagement that students addressed through this assignment held implications for their civic engagement. Carlos 
wrote about this directly, telling his disengaged self that re-engagement could be the first step toward more civic engagement. He wrote

A little more effort is needed in my case to continue with engagement...and it would possibly [allow me to] engage other activities, like a domino effect, and possibly make us more civically engaged with issues that really affect us.

Four sub-themes emerged: Commitment to dialogue, speaking honestly despite power dynamics, finding hope, and empathizing with those holding opposing views.

Ben's letter-which spoke directly to his new commitment to dialogue rather than to win arguments - was an example. Rebecca raised a similar theme to Ben, writing that one take home message from this exercise was "learning from the conflict instead of 'winning or losing,", and using conflict creatively to reveal options for action.

Three students wrote about times they did not speak up on their own behalf, and committed to using their voices going forward. Carla referred specifically to a power dynamic at play in her experience: "It was a power situation where the adults had the power and they knew I was a kid and didn't think I had what it took to overcome the situation." She wrote to her younger self to validate that it was okay to stand up for herself. Carla noted the tendency to minimize the importance of small acts of honesty: "Even though it feels like it will not make a difference, it is important to still stand up to them because every little action can equate to a bigger change." She demonstrated wisdom in how she incited her younger self to courage: "Continue to be yourself and build people up to re-engage even though it is so challenging. This is the time to get more involved than ever even though you want to do the opposite." Carla focused on the 
importance of the act of speaking up, rather than convincing people. This demonstrated both a process orientation as well as courage and vulnerability.

Josue also wrote about using political voice. Referring to a reading on nonviolent movements, Josue wrote to his disengaged self,

So many things can change as long as you have a voice and as long as you don't take it to that level of violence...You need to stand up and have the conversation of what's going on and how can these changes happen...Your voice is the most powerful thing in the world, so use it, but use it to get along with people because they do matter.

Finally, some students showed evidence of learning a more subtle outcome - they noted that past difficulties directly affect civic engagement. This outcome was important because learning this could enable students to address their own and others' disengagement with many more strategies than frustration and admonitions. If they could get under the surface of engagement, they could lead themselves and others towards it more skillfully. Though most students showed this learning implicitly in their writing, Ayah wrote about it directly as she wrote about civic discourse: "Whenever something triggers a memory from the past or touch[es] base with a personal issue, the aggression level of the conversation escalates quickly." Additionally, she wrote about general disengagement in reflecting on her personal disengagement: “This strategy [Brown's "Emergent Strategy"] changes our position to be proactive not reactive citizens in the current political climate." 
An important example of this came from Carla, who wrote that reintegrating her previous self could directly fuel future civic engagement:

This event took so much positivity and excitement from you. You looked [previously] at the world like all people were good and acted on it...I want to bring back that positive happy person that wants to make a positive difference in people's lives to help to be better civically engaged now. I could use that now to [volunteer]. I was a positive leader looking to make a positive change in the world up until this incident and I could use that positivity again.

Carla was the student who most directly named a key underlying goal of the assignment. By using empathetic analysis and identifying what aspect of herself she had lost contact with after a disengaging experience, she used this insight to attempt a renewed relationship with this aspect of herself going forward. This aspect had direct relevance to her civic participation.

\section{Additional Finding 2: Some students found the assignment to be powerful or impactful.}

According to several Dear Jane notes and student comments in class, this assignment was overall impactful. Part of this impact came from a realization by some students that this process could be used again, which was the intention. Rebecca wrote:

“There are so many more times you have been disengaged because of [this], so this letter is for whenever you feel that way again." Furthermore, she added, "It's okay to feel the way you do, and this is a way to try and avoid disengagement again." Along these lines, Ansar addressed his letter to "Dear Disengaged Ansar" and signed it "Ansar Satih, 
Engaged." This suggested that he saw himself as different for having gone through the process of implementing the re-engagement tool.

\section{Implications of findings from Narrative Part Two}

Overall, these findings suggest that the re-engagement tool was indeed effective for most students in the study. Additional Finding 2, that students noted the political implications of their disengagement and re-engagement, was particularly meaningful. This suggested that the tool, though it does not stipulate that students discuss civic disengagement, did indeed seem to impact students' civic capacity. In addition to this important finding, we also found three indications that the re-engagement tool was having a desired impact.

First, all students were able to implement the South and West components of the tool. In writing to a disengaged "self," they began in the South of the tool with "Identify and relate to aspects of self not free to engage." In doing so, they utilized the capacity in the South of the Model: "Relate to vision, self and others." They demonstrated the competencies lying in the South of the Model: Connection (by connecting to self) and Identifying Gifs and Interests (by considering what this part of themselves could contribute). All students also worked effectively with the second step of the Tool, "Empathetic analysis and discernment of feelings and needs." In doing so, they showed part of the capacity lying in the West of the Model: "Engage from compassionate discernment and learn from experience." They demonstrated the competencies in the West through empathy (caring about the self's feelings and needs) and engagement (responding to those feelings and needs). According to the Nonviolent Communication 
framework, doing just this work of connecting, empathizing and engaging is, in itself, valuable (Rosenberg, 2003). Rosenberg (2003) sees this work as essential for "affirming life," empowering personal choice, and inoculating citizens against "hierarchical or domination societies" (p. 23). All students showed an ability to engage the South and West stages of the tool, and so may have benefited in these ways.

Secondly, most students were able to engage with the East portion of the tool (“Articulate/invoke civic vision or values") deeply enough. The assignment prompted only general consideration of civic vision, leaving this for Narrative Part Three. This appeared to be adequate; students wrote to their "selves" about their desire to re-engage, and so in a sense, the vision they were sharing was simply one of personal wholeness. As Kecskes, Nishishiba and Morgan (2013) have said, wholeness is an important goal in and of itself. As Ginwright (2018) has noted, personal healing can be seen as an important enabling factor for increasing civic empowerment. Through the HCEE lens, students' capacity to contextualize their past disengagement and gain a new perspective is indeed key to developing civic capacity. The findings showing students' awareness of the political implications of their process with this assignment suggested this all the more.

Finally, and most significantly, most students' work with the tool seemed to lead to re-engagement and a sense of enhanced capacity. As students described their realizations and their reframing of their past experiences, it indeed seemed that they had moved into the North stage of the tool, "Growth in capacity to use gifts, in service of vision, in civic sphere." There seemed to be for a number of students a sense of increased Trust, one of the Model's competencies in the North. This trust was seen, for example, in 
students who wrote encouragingly to themselves in their letters; they showed a sense of renewed willingness to engage and trust that their efforts could be fruitful. We may have seen some growth in the competency of Interconnection as well. Students who wrote about their desire to deploy their reclaimed abilities (e.g. Ben's reference to wanting to affect people or Clara's reference to "the world is waiting") seemed to show a desire to contribute to the whole, rather than use their gift for personal interests. Ultimately, HCEE courses aim to increase the capacity found in the North of the Model: "Use gifts in context of vision, relationships and discernment in the civic world." It is beyond the scope of the study to predict how students will use this growth in their future civic lives. We do see, however, an apparent growth in capacity as students worked through the tool and began to reconcile with key moments of disengagement.

\section{Narrative Part Three: Civic Vision Narrative}

Narrative Part Three (Appendix D) was assigned in Week Nine. It was meant to reinforce students' ability to utilize the re-engagement tool, and to solidify their understanding of themselves as civically-able citizens who understood their important role in governance. The assignment offered four prompts, corresponding to the four quadrants of the Model. First, students were asked to articulate a civic vision, which could be "a kind of relating, a process, a set of values, a policy approach, etc." (East). Second, they were prompted to describe the leadership qualities needed, both generally and for them specifically, to move toward that vision (North). Third, students were asked what personal challenges they would need to confront in order to lead and move toward the vision (South). Finally, the assignment prompted students to draw on class readings 
and materials to bring context and compassionate insight to those challenges (West). In writing these essays, students were drawing on the entirety of their course learning, including our in-class construction of criteria for effective civic leadership, several articles that described communities moving toward civic visions in various ways, and reading and discussion on mindsets of engagement (See Appendix A).

The learning outcomes for this assignment were:

1. Students will identify a civic vision that aligns with democratic principles and values. 2. Students will identify leadership qualities that emerged from the course and/or from current theories about civic leadership such as New Public Service.

3. Students will honestly assess personal challenges in terms of what growth they aspire to in order to lead toward their vision(s).

4. Students will bring empathy to their challenges and adopt a more empowered orientation toward meeting those challenges.

\section{Results}

I analyzed these essays, as before, by reading them three times. On the second reading, I noted evidence of the degree of student learning. Through a series of memos, I identified themes. I then read the papers for a third time to assess the appropriateness of these themes. As with the previous narrative, I found that student learning generally occurred at levels. In particular, the level at which students were able to articulate their civic vision and the level at which they were able to reframe their own civic engagement challenges varied widely. Only a handful of students were able to fully meet outcomes number one and number four (from above). Overall, these assignments seemed rushed. It 
may be that these essays are a measure of what students had internalized throughout the term, rather than of what they could generate through further reflection and perspective on this learning. Below is the summary of the findings:

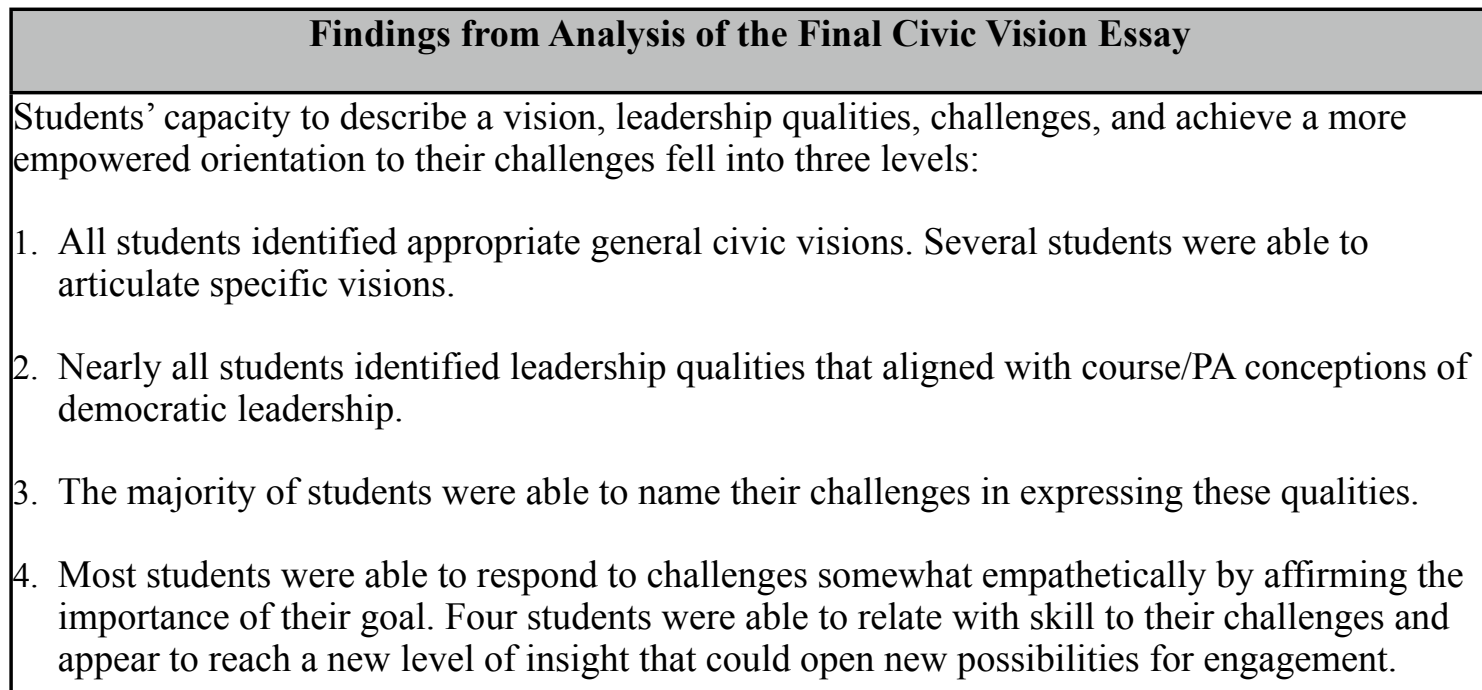

2. Nearly all students identified leadership qualities that aligned with course/PA conceptions of democratic leadership.

3. The majority of students were able to name their challenges in expressing these qualities.

4. Most students were able to respond to challenges somewhat empathetically by affirming the importance of their goal. Four students were able to relate with skill to their challenges and appear to reach a new level of insight that could open new possibilities for engagement.

\section{All students identified general civic visions. Several students were able to articulate specific visions.}

The findings around this outcome were similar to those from Part Two, the letter

to self. However, two more students in addition to Karen were able to articulate a relatively specific civic vision. The majority of students interpreted "civic vision" in a general sense and wrote about visions for democratic society, rather than for their own democratic engagement. Nonetheless, their generalized visions did align with course content and with (academically) accepted understandings about democratic societies, such as the importance of social trust, independent journalism, and deliberative decision making.

Students who wrote about civic vision at a general level tended to take an idealized tone, yet their hopes for the evolution of American democracy struck me as 
genuine. For example, Ben wrote that he wanted "a society where we are able to disagree and are not divided along ideological lines.” Though general, Ben identified several important ways to move toward this, which reflected his learning from the course readings and activities. He wrote that:

We need to have trust in ourselves and in our neighbors, so that we can work together. We need to be brave in order to step out of our comfortable social enclaves to forge relationships with different minded people and groups. When we do have the courage to listen to those who do not agree with us, we need to listen and respond with empathy. All of these actions require us to do something difficult or uncomfortable, but these difficulties are not insurmountable. With focus and positive leadership we can overcome our habits.

Ben's essay demonstrated understanding of several competencies of holistic civic engagement: empathy, engagement, connection, and to some extent, trust in a process.

Clara also demonstrated some holistic civic engagement thinking woven into a civic republican ethos. She wrote,

If I want to be a stronger participant in my society I can succeed at this by staying present in the moment, and not just looking for my own personal gain. We all need the community that democracy brings, and building our civic engagement strengthens this for society as a whole.

Clara's point that citizenship involves thinking about collective, rather than personal, outcomes resonated with the democratic theories emphasized in the class. Her understanding about collective benefit demonstrated another key learning goal. Most 
importantly perhaps, she named "staying present in the moment" as an antidote to an overly individualized focus. This suggested a level of trust in collaborative processes, and perhaps a desire to retain a degree of openness to others' input rather than committing to a self-interested stance.

Carlos also raised several key themes, writing that democracy required social capital and was harmed by "us" versus "them" thinking. He named the value of equality, the importance of listening to minority views, and of activism. Ansar had a valuable, if idealized vision of "fixing the media," meaning that mass media should be held accountable for informing and not "tricking" the public. Ayah had a simple vision, but it was significant given she was raised in a Middle Eastern monarchy. She envisioned more value being placed on civic responsibility, as well as an increased sense of belongingness. Jesse's general vision also seemed relevant; he envisioned more space and time for citizens, "to explore their interests" and "assemble together to create something new." Jesse's response suggested some demonstration of Trust, an HCEE competency situated in the North. He revealed a trust in the process of co-creativity, and he trusted that with time and space, people could develop new and sustainable ways of living. Finally, Josue's general vision was for increased trust and social capital. He wrote that with trust, more collective action toward peace could emerge. The generalized visions discussed by the majority of students were all in alignment with the theories presented in class, especially social capital, civic republicanism, and emergent strategy.

Three students identified more personalized or specific visions. Karen was able to name the policy outcomes and political context for her vision. Rebecca described the 
organization she would like to found. Like Karen, Rebecca wrote about how her life had brought her, through struggle, to this particular commitment. Carla was semi-specific in her essay, writing about her vision of educational equity with relatively detailed reference to the current context and need. The key finding here was that only those students who had substantive life experience on which to draw were able to combine course learning with their life learning to formulate a specific civic vision.

\section{Nearly all students identified leadership qualities that aligned with course and/or PA conceptions of democratic leadership.}

There was surprisingly little overlap in which leadership qualities students identified as important for achieving their civic vision. Nearly all students mentioned qualities that aligned with course themes and common theories of leadership in Public Administration, such as New Public Service. Only two students, Ayah and Josue, mentioned traits that were more in alignment with hierarchical leadership. Table 4.1 summarizes the categories of leadership qualities with examples that students mentioned and the number of mentions.

Table 4.1: Categories of Leadership Qualities Mentioned by Students

\begin{tabular}{|l|l|l|}
\hline \multicolumn{1}{|c|}{ Leadership Quality } & \multicolumn{1}{|c|}{ Examples } & \multicolumn{1}{|c|}{ References } \\
\hline Strategic, able to sustain \\
motivation & $\begin{array}{l}\text { - Makes a "conscious choice to devote energy into } \\
\text { guiding what they believe in." }\end{array}$ & 5 \\
& $\begin{array}{l}\text { Strategic about which battles should be fought and } \\
\text { which left for another time. } \\
\text { Has endurance, aims for change that takes place } \\
\text { over lifetimes. It's vulnerable but worth it because } \\
\text { of the possibility. } \\
\text { Can manage the level of distraction common in } \\
\text { society. } \\
\text { Has initiative, motivation, and inspiration. }\end{array}$ & \\
\hline
\end{tabular}




\begin{tabular}{|c|c|c|}
\hline Leadership Quality & Examples & References \\
\hline $\begin{array}{l}\text { Growth Mindset, } \\
\text { positivity }\end{array}$ & $\begin{array}{l}\text { - Growth Mindset required to learn from mistakes } \\
\text { and sustain engagement over time. } \\
\text { - Hope and optimism through setbacks. } \\
\text { - Inspires others. }\end{array}$ & 4 \\
\hline $\begin{array}{l}\text { Empathetic listening, } \\
\text { compassion }\end{array}$ & $\begin{array}{l}\text { - Understands that "Humans need to be understood, } \\
\text { affirmed, validated, and appreciated to have } \\
\text { positive participation." } \\
\text { - Sees importance of listening to minority views. }\end{array}$ & 3 \\
\hline $\begin{array}{l}\text { Integrity, equity- } \\
\text { orientation }\end{array}$ & $\begin{array}{l}\text { - Notes that integrity begets legitimacy. } \\
\text { - Values equity. } \\
\text { - Capacity to stand up for one's values. }\end{array}$ & 3 \\
\hline Diversity, inclusivity & $\begin{array}{l}\text { - All types of leaders are needed. There is a leader } \\
\text { in all of us. We make an impact through many } \\
\text { small acts accomplished together. } \\
\text { - Leader should come from the community they are } \\
\text { leading. } \\
\text { - Communication skills. }\end{array}$ & 3 \\
\hline $\begin{array}{l}\text { Charismatic leadership, } \\
\text { efficiency-orientation }\end{array}$ & $\begin{array}{l}\text { - Using empathy to persuade followers. } \\
\text { - Being a "power speaker" who can "motivate an } \\
\text { entire community to be able to get things done in } \\
\text { an organized way that doesn't waste time." }\end{array}$ & 2 \\
\hline
\end{tabular}

As the summary table shows, students were far more likely to name qualities such as having a process-orientation, being empathetic and inclusive, and being intrinsically motivated by values (rather than extrinsically motivated by power), than they were to mention qualities that allowed for persuasion and efficiency. This showed growth beyond the pre-assessment, in which receptivity was the primary understanding of civic leadership. It further suggested that the qualities students wanted to embody would also be qualities that supported holistic engagement. A growth mindset, empathy, integrity, and inclusiveness are all qualities that support the capacities and competencies. They also support the process of re-engagement. 


\section{The majority of students were able to name their challenges in expressing these qualities.}

All but two students named challenges they personally would face in expressing their named leadership qualities. Students appeared honest in their assessment of themselves. They named challenges such as losing focus or motivation, doubting worth, or holding a win-lose mindset. Students' articulation of their challenges revealed a solid sense of what qualities they would need to develop in order to grow in their capacity for civic leadership.

Students showed both self-awareness and honesty. Ben wrote, "When I disagree with someone I tend to put up walls and immediately take on a defensive position...I do this out of fear of failing or looking stupid." Josue wrote "Being honest I'm really not the most go-getting type of person." He acknowledged that he passed significant time using his phone and fell into the patterns we discussed in class of "listening with intent to reply" rather than listening openly. Ansar noted he tended to lose focus and be short on patience. Some students spoke a bit more gently of their challenges. Ayah referenced introversion and Jesse named his challenge as "consistently committing time to push my comfort zone."

Three students employed more active compassion in their discussion. Rebecca wrote about the challenge of self-confidence:

I never think I am educated enough or worthy enough to do something like this. I keep thinking that anyone else would be better at doing this than me...Even 
writing this essay I keep thinking that I should change my civic vision to something simpler.

In writing, Rebecca realized her tendency to doubt herself, and that this doubt was creating an additional challenge. Carla also wrote about doubt as a challenge. "I would face a lot of self-doubt going forward because I feel that I am faulty and therefore I have no business taking part in this." Carla brought critique to her own thinking, writing “Inequality thinking is unfortunately inside me...There are norms I don't think I believe in, but I am always skewed." Carla acknowledged that some societal norms had become her own, and they were limiting her. By reflecting on their own doubt, Carla and Rebecca began the process of making space for themselves to act in spite of it.

\section{Most students were able to respond to challenges somewhat empathetically by affirming the importance of their goal. Four students were able to relate with skill to their challenges and appeared to reach a new level of insight that could open new possibilities for engagement.}

Most students responded to their challenges by reiterating how important the civic vision was. On one hand, this was a constructive response that validated their vision and participation. On the other hand, this response did not appear to create space for an evolved relationship to the challenge. For example, Ben wrote "I need to remember that failing isn't the end of the world it just is part of learning...I need to step out of my comfort zone and into my stretch zone more often.” Ansar responded with a utilitarian approach. He wrote that meeting the right people and developing social capital would help him achieve his vision by making it a shared goal. I suspected that the level of 
responses for most of the class partly resulted from their lack of time and energy at the end of the term.

Those few who did bring a deeper level of analysis and empathy seemed to open new possibilities for engagement. Karen wrote about working with her challenges of overwhelm and shut-down due to a sense of others not caring about animal welfare. In responding to this challenge in her essay, she acknowledged that though she did not expect everyone to care as much as she did, she did trust in the moral compass of the majority of people. She then named the importance of finding a community of practice through which she could strengthen her impact and gain support. Karen then summed up her response to the challenge of hopelessness, showing that she had reoriented to this challenge and seemed to create space for a new response going forward. She wrote that civic engagement was necessary in a democracy, and after discussing several key readings such as a Václav Havel essay, concluded:

Despite any odds that are stacked against someone, current laws and regulations, naysayers, or setbacks that may arise, maintaining hope for a long-term strategic objective is important. The difference can be made now, and modest instances can amount to large changes.

This valuing of small impacts and a willingness to engage without guarantees of success were noteworthy.

Like Karen, Jesse wrote about his challenge of "draining enthusiasm," resulting from an ongoing pattern of "work-school-repeat." His response to this challenge was to invoke a different mindset based on remembering that he had rights, access to 
community, to technology, and to infrastructure. He could ask for help when he needed it. For Jesse, this went so far as to remind himself of "the well of energy that anyone can tap into if they need." Jesse wrote on this large scale throughout the term, discussing belief systems, mindsets and his felt sense about the nature of the world. I interpreted his essay as a re-commitment to his core beliefs of trust, abundance, and interconnection.

Rebecca revisited the challenge of self-doubt in the final essay. Though she did not have specific strategies to move through her doubt, her awareness seemed solid, and it was possible to imagine her implementing strategies going forward. She wrote of her vision of an advocacy nonprofit: "This is something that I am truly passionate about and I won't let my self-doubts stop me, but I do notice that it slows me down a lot. I want to be able to find a way to get past this mental barrier." Rebecca wrote more directly and concisely about self-doubt than she had in the previous essay. While previously she had seemed to entertain the possibility that her incompetence was real, in this assignment she framed this as self-doubt. This created more room for her to potentially move past it.

Finally, Carla's essay was again striking as she revealed unusual levels of selfawareness. Like Rebecca, Carla addressed the challenge of negative beliefs about herself, writing, "I think the biggest thing is that I feel that I am just not cut out enough for it and therefore I am better off staying quiet." She addressed this differently from Rebecca. Carla provided two responses. First, she referred to learning from the course that leadership does not require perfection or public visibility. Given this, she noted, "I can be an average human with flaws and still have the chance" to contribute. Furthermore, "It is easy to be discouraged in doing something big, but also critical to understand that it 
doesn't have to be big to make a difference, all actions add up." Secondly, Carla responded directly to the pernicious challenge of telling oneself that one's perspectives are invalid. She wrote, "Another big thing I learned in class was to question beliefs we hold." She referred to a Palmer article that argued for the importance of emotionally engaging with patterns of inequality in America: "This is exactly what I want to achieve, and this validates that there is challenging heart-work, and I am not crazy for thinking that there are things wrong that the majority of people aren't discussing." It was significant that Carla was not only able to identify her internal voices saying she was "not cut out for it" and "crazy," but her synthesis of class learning enabled her to choose more accurate beliefs that could potentially form the foundation for more empowered engagement.

Jesse, Karen, Rebecca and Carla all responded to their own engagement challenges with insights that seemed to enable more engaged responses going forward. These four were able to speak to themselves about their own beliefs and mindsets. They gently but firmly questioned beliefs about themselves and the world that were underlying patterns of their disengagement. By engaging first with a vision, then with leadership qualities and their personal challenges, they were able to uncover and target mindsets of disengagement. Whether believing the world does not care, or that one is not up to the challenge, these mindsets could be a significant hinderance to sustained and courageous civic engagement. Rather than confronting these beliefs with insistence and trying to force them to retreat, these students approached their beliefs with a kind firmness. They seemed to be simply making a new, more informed, choice about how to see the world 
and themselves. Given that world views can shape patterns of emotions and behaviors, their work had the potential to be significant.

\section{Implications of Findings from Narrative Part Three}

The findings from Narrative Part Three spoke to students' attainment of the HCEE competencies. In the East, students showed they could connect to large-scale visions for democratic society. We saw this, for example, in Ben's reference to social trust and communication and in Carlos's vision of moving away from "us versus them" thinking. In the North, we noted Trust embedded in students' articulation of civic visions; they indicated the value of trusting in other citizens and committing to collaborative processes. They showed a sense of Interconnection in their references to the common good and their capacity to serve. Importantly, students appeared to grow in their understanding of the importance of strategy and sustained effort as key to civic leadership. This was a significant change compared to the emphasis on receptive leadership shown from the pre-assessment.

In the South, we saw students demonstrating the competencies of Connection and Identification of Gifts and Interests. This was seen in students' connection with their own challenges, including Rebecca's reflection on her self-doubt and Carla's consideration of her confidence. Many students seemed to reckon with their challenges and express a wish to move past issues like doubt in service of visions. We could see, to some extent, students demonstrating the competency of Identifying Gifts and Interests as they wrote about their goals and ideals. Karen, for instance, discussed her recommitment to animal welfare, and Carla showed a commitment to use the gifts that her renewed confidence 
could uncover. Most clearly, in the West, we noted students showing Empathy toward themselves and others as they wrote about their challenges and visions. The competency of Engagement was seen in essays in the form of empathetic analysis and a value of the importance of engaging in civic life. There was less direct evidence of the competency of Critical Insight (East). To some extent, this could be seen in Carla's critique of her own pattern of lacking confidence. However, Critical Insight could be supported more thoroughly in future courses, which Chapter Five considers.

Finally, based on Finding 2, students achieved a key cognitive learning benchmark: they were able to articulate conceptions of democratic leadership that aligned with course goals. This suggested that the addition of the core narrative sequence did not hinder this cognitive content learning.

\section{Final Self-Assessment}

Students responded to three prompts during the last week of the course: What did you value learning? What civic engagement goal do you have for yourself going forward?" and How did you notice your capacity to use power change over the term? To analyze the data generated, I created master lists of students' responses to all four questions. I then consolidated responses according to themes. Below I report on responses to the two questions about civic engagement learning and goals. The tables summarizing these findings list the themes, examples of student answers that fell into that theme, and the number of times that theme was raised.

In examining the responses, three patterns emerged. First, students wrote about the value of the Learning Mindset. This was a meaningful theme because the Learning 
Mindset (Dweck, 2016) was a key means for teaching the competency of Trust (that is, by trusting a learning process and being learning-oriented, citizens are less likely to give up their endeavors). Second, students brought up the importance of relationships and networks as the first and foundational element for empowerment and civic action. This was important because it demonstrated orientation to the capacity in the North to "Use gifts in context of vision, relationships and discernment." Students' civic expression, they wrote, would be grounded in communal contexts. Finally, some students referred to vision as a driver of the engagement process. This was an important finding, since the notion of vision as an impetus for change (rather than fighting against as impetus) is core to the HCEE Model.

\section{Question One: What did you value learning?}

As I explained to students, this question was asking them to assess what aspect of the course they had found most valuable, meaningful, or important based on their own lives and goals. Responses to this prompt are summarized in Table 4.2 below.

Table 4.2: Themes Identified from "What did you value learning?"

\begin{tabular}{|l|l|l|}
\hline \multicolumn{1}{|c|}{ Theme } & \multicolumn{1}{|c|}{ Examples } & Frequency \\
\hline $\begin{array}{l}\text { Learned factors that } \\
\text { contribute to civic } \\
\text { engagement/disengagement in } \\
\text { society }\end{array}$ & $\begin{array}{l}\text { Reasons for declining participation in } \\
\text { associations } \\
\text { Concept of social capital } \\
\text { C.S. History related to civic engagement } \\
\text { Qualities of effective civic leadership, e.g. } \\
\text { perseverance and strategic planning }\end{array}$ & 9 \\
\hline $\begin{array}{l}\text { Learned value of good } \\
\text { listening and learned from } \\
\text { listening to classmates }\end{array}$ & $\begin{array}{l}\text { Listening to understand (versus to respond) } \\
\text { Learning from others in class } \\
\text { Empathy \& Nonviolent Communication }\end{array}$ & 4 \\
\hline $\begin{array}{l}\text { Learned value of voice and } \\
\text { speaking skills }\end{array}$ & $\begin{array}{l}\text { Being able to speak } \\
\text { How important my voice is }\end{array}$ & 3 \\
\hline
\end{tabular}




\begin{tabular}{|l|l|l|}
\hline \multicolumn{1}{|c|}{ Theme } & \multicolumn{1}{|c|}{ Examples } & \multicolumn{1}{|c|}{ Frequency } \\
\hline $\begin{array}{l}\text { Gained sense of } \\
\text { empowerment and hope }\end{array}$ & $\begin{array}{l}\text { "I control my future and the change I desire" } \\
\text { "I'm just one of many people fighting" for } \\
\text { social benefit }\end{array}$ & 3 \\
\hline $\begin{array}{l}\text { "Self-realization" } \\
\text { and embracing challenge in } \\
\text { civic engagement }\end{array}$ & $\begin{array}{l}\text { Getting "out there" with community-based } \\
\text { project }\end{array}$ & 2 \\
\hline
\end{tabular}

As the table shows, just under half of responses referred to theories of civic engagement, such as social capital and civic leadership. This was the more cognitive dimension of the course. Just over half of responses referred to a change in mindset, orientation or values. Nearly all of these themes related to the emotional or spiritual dimensions of the course. I suspected there may have been a bias toward reporting on the value of theoretical learning since the "value" of this is more established at the university. However, it is also possible that students over-reported on their non-cognitive learning thinking I would be pleased. Though somewhat difficult to interpret, responses to this question suggest that not only did students grow toward many of the key intended outcomes, they also valued that learning.

Question Two: What civic engagement goal do you have for yourself going forward?

This question was intended to elicit two facets of civic engagement learning. First, it would reveal what goals students saw as worthwhile, which would speak to their strategic understanding. Second, it would illuminate how empowered students appeared to be in their civic aspirations. (I should note that this goal was empowerment, as distinct from both grandiosity and self-diminishment.) Rather than asking directly the same questions that I posed in the pre-assessment (What does civic engagement look like? 
How do you know it is effective?), I chose to use this exercise primarily as a teaching tool rather than a data collection strategy. The question about their goals would elicit both their understanding of civic engagement and their sense of what would comprise effectiveness. By asking students about their goals, I was intending to serve my research aims while also giving them a valuable opportunity for focusing on their own intentions, which could strengthen intrinsic motivation.

Table 4.3: Themes Identified from Students' Civic Engagement Goals

\begin{tabular}{|l|l|l|}
\hline \multicolumn{1}{|c|}{ Theme } & \multicolumn{1}{|c|}{ Examples } & Frequency \\
\hline Community involvement & $\begin{array}{l}\text { - "Bring a community together" } \\
\text { "Stay connected to stay empowered" } \\
\text { - Active in community (2) }\end{array}$ & 4 \\
\hline Stay aware, educated & $\begin{array}{l}\text { - Stay aware of issues } \\
\text { - Continue to educate myself } \\
\text { Vote }\end{array}$ & 3 \\
\hline Strategy toward a \\
personalized goal & $\begin{array}{l}\text { Meet people in the nonprofit world and see if I } \\
\text { can enter it } \\
\text { Own or finance a rescue farm and bring } \\
\text { awareness to animal welfare } \\
\text { "Stay engaged with Portland's local } \\
\text { government, maybe be a part of it someday!" }\end{array}$ & 3 \\
\hline Personal efficacy & $\begin{array}{l}\text { Be efficient, manage my time and focus } \\
\text { Keep valuing myself in a healthy way }\end{array}$ & 2 \\
\hline
\end{tabular}

These results suggest that students had evolved well past their initial understanding of civic engagement as neutral responsiveness to a community. Rather than just listening to a community, students aimed for active participation, for empowerment, and for leadership. Clara wrote, "By being a more active member in society I hope to connect and learn how to cause more change." It was significant that connection was a first step, but not the final goal. Three students gave very specific goals that they had 
developed over the term. Two students revealed that they felt their capacity for outward engagement depended first on their inward work - to choose their focus and concertedly value oneself. Three students gave relatively neutral responses related to "staying aware." However, those three students had written earlier in the term that this level of participation was a struggle for them. Though frankly I wanted them to aim more strategically, staying educated and not shutting down is still a worthy goal for many. Question Three: How did you notice your capacity to use power change over the term?

I phrased this question vaguely in order to assess both how students would define power at this point in the course, and to gather their sense of their growth in wielding it. Overall, the group defined power as generally synonymous with engagement. No one defined it in negative terms or conflated it with abuse of power. About half the students wrote that they had an increased understanding of power and investment in using it in future. The other half felt that they had already, over the course of the term, made strides of some kind. Of this first half, Carlos was the most clear that he had not yet reached his goals: "I don't think I have used power very much this term, as much as I learned how, but I definitely see potential in the use of empowerment. Just needs a little more organization." In this response, Carlos revealed a sense of knowing generally where he wanted to go, but not necessarily knowing what steps would take him there. Stephanie's response suggested a similar expectation that using power would come in the future, but she had some steps in mind: "I feel more empowered to pursue the career path [law] I was unsure of and use all the knowledge I've gained to do so in a way that helps others, hopefully." Rebecca also referred to renewed clarity and energy, a sense of "wanting to 
go back out there and make a difference. I'm more passionate on my own civic engagement goals more than ever." These students stated that they felt energized for the future.

Several other students responded to this prompt by describing what they felt they had already gained in their capacity to use power. Jesse wrote that "Through this course I've found meaning and energy. To live a life engaged in civic society means facing challenges and disengagement. I've learned to draw power/energy from those who share my vision and values in life - pivotal for engagement and growth." For Jesse, it seemed that part of use of power lay in acknowledging difficulty and strategically meeting the challenge. Ben also referred to meeting challenge, which for him was a pattern of being "combative." Ben wrote, "My capacity for empathy has grown. Doing readings that explained the importance of trust made me realize how little of it I had in myself and others. I think I listen to my needs and others' needs in a way I never used to, I used to be very combative." It seemed Ben had made a choice to try to replace this past pattern with empathy and receptiveness. For him, this felt like an increase in his use of power. A final example came from Karen, who shared two points of learning: First, she regained a sense of hope, framed as "one person can make a difference." Second, she "absorbed selfpatience" and learned "to deconstruct the standards I set for myself." Karen was likely referring to an increase in her capacity for self-compassion. Overall, students defined "capacity to use power" as being whatever allowed them personally to feel more energized and aligned with their goals, including general goals about who they wanted to be as a person and citizen. 


\section{Additional Findings}

Students' responses to the prompt about what they had done to maximize their own course learning were also revealing. Two students wrote that they had followed the class suggestion to "go into stretch zone and interpret failure as learning." For instance, Rebecca wrote, "I tried my best to be more extroverted and talk in class more, which is something I seldom do in other classes." Two students wrote that they had remained open minded. Two wrote that creating connections with classmates had helped them learn. Ben added, "I practiced need language [from Nonviolent Communication] and it allowed me to empathize more completely in my day to day life and marriage." Students also mentioned diligence with readings, active listening, and not multitasking, as tools they had employed. The significance of these responses is that students developed skills as part of participating in the course that served them academically but also had potential to serve them in the civic realm as well. Listening, openness, focus, stretching oneself, and diligence are all underlying capacities that have important value in the public sphere.

In their final Dear Jane notes of the term, several students gave additional responses to the questions from the self-assessment. Framed as gratitude, students revealed more about what they had valued from the course. Their responses fell under the same themes, helping to validate the findings. For instance, Business major and former nightclub manager Karen's note underscored the importance of students' learning about courage and stretching themselves for engagement: "Thank you for this term. It was extremely out of my comfort zone but I believe that is beneficial for learning and growing. It definitely made me more interested in staying civically engaged." Carla made 
a key connection in her note; she indicated that she had learned on both the cognitive and emotional levels and that this impacted her sense of efficacy:

I truly have felt that I received a lot back from this class. I am way more informed on things around me. Also, I have learned it is important to understand my feelings and the feelings of other people around me. It will help me live better with others and hopefully help solve problems sooner.

Josue also referred to a combination of cognitive and affective learning, and stated that class learning had impacted his life: "This was one of my favorite classes I've taken since being in college. It opened my heart and mind to be more understanding. This class was a huge reflection of what's going on in my life and I needed this.” Ansar's note echoed this theme as well. He wrote, "It was a pleasure taking this course with you. It allowed me to do some very much needed self reflection, that has allowed me to make my life better overall." Ansar was likely referring to the letter to self assignment. Ansar's take on that assignment was a little different from what I had intended. However, it seems that simply taking concerted time to reflect, identify his feelings, and respond from a place of insight, was useful, and potentially a new step for him. Though his letter was not explicitly civic, this skill is relevant and supportive of possible future political discourse. Ansar was identified as a "natural leader" by his peers. A business owner, Ansar's implication that he learned a new level of self-reflection was significant.

Finally, some of these notes suggested that some students had felt care and connection as part of the class environment. For instance, Carlos wrote "I enjoyed this 
class and want to thank you for your kindness." Creating a community of care was an important goal in designing for holistic civic engagement education.

\section{Reflection on Class Community}

Students responded to the prompt "Give two words that describe this class as a community and why you chose them." I identified four themes in analyzing these words, which are summarized in Table 4.4. All the words chosen had a positive connotation. This supported the supposition that a caring class community would encourage HCE learning. However, based on the data collected, we are not able to assess the degree to which HCE learning is dependent upon or served by this kind of classroom environment.

Table 4.4: Words to Describe this Class as a Community

\begin{tabular}{|c|c|c|}
\hline Theme & Examples & Frequency \\
\hline Engagement & $\begin{array}{l}\text { - Individuals interested in participating } \\
\text { - Passion; classmates have goals for change. "Many are } \\
\text { proactive in their desire to help others." } \\
\text { - Conversations emerged and "bloomed" }\end{array}$ & 7 \\
\hline $\begin{array}{l}\text { Inclusiveness, } \\
\text { respect and } \\
\text { understanding }\end{array}$ & $\begin{array}{l}\text { - "No matter what group I'm in or where I sit, the people } \\
\text { that are around will start a conversation with you." } \\
\text { - Respect for diverse views } \\
\text { - Sense of equality, equal treatment } \\
\text { - Sense of understanding between people } \\
\text { - Respect was easy because low ideological diversity }\end{array}$ & 10 \\
\hline $\begin{array}{l}\text { Authenticity, } \\
\text { vulnerability and } \\
\text { enjoyment }\end{array}$ & $\begin{array}{l}\text { - Could be myself } \\
\text { - Okay to share personal/vulnerable things } \\
\text { - "We are willing to share our ideas, questions, and } \\
\text { hesitations in this community." } \\
\text { - Fun } \\
\text { - Got to know others } \\
\text { - Great conversations } \\
\text { - Self-awareness fostered } \\
\text { are poorly supported, we are willing to reengage for the } \\
\text { sake of understanding" }\end{array}$ & 8 \\
\hline
\end{tabular}


The three themes were interconnecting. References to an inclusive environment were the most common, but a sense of an engaging and enjoyable space was also commonly referred to. Students also mentioned a feeling they could be vulnerable, authentic, or open to learning within the class. It is important to recall that these responses were not anonymous. However, to the extent that students were honest in their assessments, it seems that students had a generally positive experience of class community, and that likely the community-building component of HCE education was largely met.

\section{Course Two: Fundamentals of Public Service}

Course Two was taught as a fully online course in the Spring of 2019. A majority of students had a career interest in public service. Course Two presented New Public Service as a primary frame, and the core narrative sequence - trimmed to two assignments - connected the concepts of service with the Model and re-engagement tool. In the following sections, I present findings from the pre-assessment, the two narrative assignments, and the weekly discussion posts.

\section{I.Pre-Assessment: What is Public Service?}

I asked students in Week One to create a video (or typed) post that related one positive experience with service and one challenging experience with service. This post also prompted students to share something "we would not know about you unless you tell us" and "one thing you look forward to in your life this Spring."

\section{Results}

Analysis of student posts suggested that though students had a positive association with public service, they did not have either 1. A deep understanding of the systemic 
context for effective service, nor 2. A sense of what made service fulfilling aside from seeing a quick result.

\section{Commitment to Public Service}

Though I did not directly prompt students to comment on their commitment to service, this high level of investment was the most striking finding from the preassessment. Students shared that they were passionate about public service and looking forward to a course devoted to the topic, including theory. "I am adamant about having a career in public service," wrote Meredith, and Elizabeth stated, "Service is at the heart of who I am and what I do." Some students were also explicit about wanting to learn the theories underlying the field of Public Administration. Nick wrote, "All of my career experience has been in Public Service, and I look forward to learning about some of the theoretical stuff behind effective administration and applying that knowledge to my experience and drawing upon it in the future." Alexis had a similar comment and added that she was disappointed about the online format. Christopher and Rachel both wrote that they were excited to learn more about a topic they were enjoying in their work lives. Jonas added, "This spring term I am looking forward to making contact with non profit organizations and becoming involved in more community work." It seemed most students had a lifelong interest in service, though Amelia noted, "I always wanted to edit books for a living, but the Trump administration changed my mind: I want to help people as best I can." Whether long-term or recent, students began the class with a high degree of investment. 


\section{Positive Experiences with Service}

Overall, students saw service experiences as positive if one of two criteria were met: either the experience was satisfying or it was educational. Satisfying experiences were those which allowed students to participate in a larger effort that they found important. For some, the satisfaction lay in their individual interest and investment, and for others it lay in their perception that the larger effort had been successful. Julia's positive service experiences were characterized by the latter-getting "to see the amount of people that were willing to help those in need." Justina and Elizabeth referred to the positivity of their involvement in a meaningful wider effort. For Elizabeth, it was Rotary, and for Justina it was serving on a Parks and Recreation committee. Justina wrote, "I love being involved in the things that are right near me" and Elizabeth expressed passion for involving young people in civic life. Sarah's experience was a combination of personal meaning and effectiveness of the effort. She had volunteered with an addiction recovery agency to organize their successful Lobby Day showing in Salem.

A second group of students framed their service experience as positive because it resulted in personal learning and growth. For both Jonas and Nick, service had involved travel that broadened their horizons. For Meredith, her internships with elected officials taught her valued skills such as introducing her to public policy, as well as how to interact with constituents and improve her writing skills.

\section{Challenging Experiences with Service}

In general, service experiences were seen to be challenging if there was an overwhelming amount of community need or organizational dysfunction. A cluster of 
students wrote about overwhelm in their service. Christopher, though he succeeded, as an intern, in sending a new bill through the Oregon legislature, was saddened by an overall lack of funding for foster care. Sarah, who had significant direct service experience, wrote that an overworked staff was the prime challenge. Julia had volunteered with food banks and found it challenging to see "the amount of people that required these services to live." Alexis wrote about a lack of time in her own life to engage in the service she felt was needed.

A second pattern in responses was students naming organizational dysfunction as a challenge to their service. Elizabeth, one of the more experienced and older students, wrote, "A common thread of where challenges have arisen are usually due to either a lack of vision, communication, or both from an organization." Marissa wrote of paperwork and bureaucracy in her environmental advocacy. Courtney noted an occasion on which the organizers of a volunteer event had not met ahead of time to prepare, and there was a sense of lack of connection as she "didn't know these people."

\section{Implications for Holistic Learning about Service}

Overall, students were committed to service and liked being part of successful efforts that aligned with their interests and values. They were distressed by unmet needs and organizational issues that got in the way of service delivery. As public servants, their work was "positive" if they saw a result and "negative" if the needs weren't met. This orientation to service, to efficacy, and to addressing community need, seems unremarkable within this group, but this attitude is a precious asset in democratic society. That said, there are qualities comprising the Trust competency, such as tolerance for 
uncertainty and resilience in the face of failure, that the HCEE lens indicates are useful. Though students did not need to be motivated toward public service, they could benefit from learning more tools. This course could offer two key things. First, the course could give them a theoretical framework through which to examine public service and discern what effective service would look like. Secondly, the course could help show them how to reflect on and change their perspectives in order to align with more internal, and less situationally dependent, forms of motivation.

\section{Narrative Part One: What is Service Really?}

This assignment, given in Week Three, asked students to work with Remen's (1999) "helping, serving or fixing" framework and discuss (1) an experience of being helped or fixed, (2) an experience of being served, and (3) their learning about public service based on comparing these reflections. In Narrative Part One, the goal was honest consideration of the distinct impacts of fixing versus serving. Writing about these experiences was intended to help students build a conceptual framework as a foundation from which to utilize the re-engagement tool in the following assignment. The learning outcomes for the first of the two personal public service reflection papers were:

1. Students will be able to distinguish "fixing" from "serving" drawing on examples from their lives. They will describe the significance of this distinction.

2. Students will be able to express the intention to offer service to others.

\section{Results}

Students could differentiate clearly between fixing and serving, and they could speak meaningfully both to the benefits of serving and the drawbacks of fixing. Their 
examples seemed personal, relevant, and authentic. Students appeared to be quite honest in these papers. They wrote about work and volunteer experiences, but also about their own mental health, addictions, and experiences of death. Though students had already shown their commitment to service, this assignment was intended to teach more about what it really means to serve — what beliefs and qualities does someone embody when they are of real service? This assignment could give them the opportunity to grow in commitment not just to public service, but to an empowering and respectful version of it.

To identify patterns, I re-read the papers and noted the themes that came up in each. Three class-wide themes emerged through analyzing students' experiences of being "fixed" and "served":

\section{Themes in Students' Writing about Service}

1. Students all showed evidence of understanding the difference between fixing and serving.

2. Nearly all students expressed a commitment to serve (and not "fix"). Some students also furthered this by wondering how service could become a system-wide norm.

\section{Students all showed evidence of understanding the difference between fixing and serving.}

In all papers, the authors showed that they understood the distinction between fixing and serving by drawing on appropriate examples from their own lives. They used instances of doctors, advisors, sports coaches, AmeriCorps supervisors, foster care providers, NA sponsors, volunteer supervisors, and church community members. The most common examples were from the medical field — about half of students gave examples of doctors, orthodontists, or mental health professionals acting either to serve or fix. In the majority of cases, being fixed involved receiving benevolent but rushed or 
superficial help. In some cases, there was a sense of diminishment, like the student who was told how pretty she would be after orthodontia fixed her "problematic" smile. One student wrote about a sports coach who fixed the team by bullying them. Many students described relationships with those who "served" them as respectful, authentic, nonhierarchical, and empowering. In contrast, the relationship with those who fixed was transactional or condescending. Julia summed this up in her paper: "Serving is an experience based on mutual understanding and learning while helping is one person using their own expertise to guide another person who is usually 'weaker' than the helper."

Students noted keenly just how different fixing felt from being served.

Christopher wrote, for example, that:

We see that in fixing or helping someone, one doesn't truly commit their support to another, but rather doles out contributions when it serves their purposes. Service, rather, is a commitment to assist someone without paying tribute to the ego. The ego has no place in service.

Many students echoed Christopher's conviction. Though strongly worded, I did not interpret their words as disingenuous or performative.

Another example of the passionate distinction students made between fixing and serving came from Rachel, who dealt with the bullying coach. She wrote:

These experiences have taught me just how important the behaviors utilized by people in positions of power are. If you demean and belittle people you will just chip away at their soul thus making them reliant on your authority. But if you teach and nurture you inspire greatness. When you empower others, you don't 
lose your own power you just strengthen others so that you don't have to carry the team on your own. When you serve or are being served you know because it feels like a safe space to learn through mistakes.

Though varying in their intensity, each paper showed a clear conception of both serving and fixing.

\section{Nearly all students expressed a commitment to serve (versus "fix"). Some students also furthered this by wondering how service could become a system-wide norm.}

Most students' papers included a statement of personal commitment to service, though the assignment did not directly prompt this. For some, this commitment was more general, applying to how society overall should behave. For instance, Julia wrote of her reflection: "This helps me develop ideas for Public Service because it should reflect the service us citizens give to one another." However, the majority of students moved from generalizations to write specifically about their own intentions. For Sarah, this was a direct line; she wanted to serve as she had been served when she was in recovery, and she had stepped up to do this in several ways. Erin had a similar direct connection between being served through the VA and wanting to be of service:

Fixing, helping, or serving can either create distance from you and those on the receiving end, or produce a wholeness in both parties. Reflecting on these differences...has been eye-opening and also motivating since my goal is to go into health services. 
Not everyone was clear on the outlet for their future service. Alexis stated their intentions for future public service, while acknowledging they were not sure what context that would be in:

I want to be a person who is able to look at others in all their humanness and complexities, without trying to solve them, but instead lend an empathetic hand. I think my questions moving forward are mainly around where to do that and what avenues are going to best support me in doing what I feel is right and humane. These examples continued; many students described their desire to bring their insights about service to their own work.

In some cases, students showed a particularly strong commitment to self-reflect as part of their public service. Amelia stated bluntly that "the idea of causing harm when trying to help is enough to make me stop and critically reflect on my goals as a public servant." There was a sense of valuing service enough to honestly reflect and potential encounter uncomfortable truths. Elizabeth showed this kind of investment as well, calling herself on an old pattern of overextending: "I need to hear the call of service to myself, rather than my ego and a nagging sense of duty which causes me to raise my hand to help or fix things far too often." It seemed that a few students were interested in looking at the stakes to both others and themselves if they did not do the internal work needed to serve rather than fix.

In addition to expressing commitment, two students noted a subtle but important point. They noted that helping and even fixing are necessary sometimes, and they began 
to consider how they and others could help without seeing people as weak. Nick wrote about this in his paper:

As I continue with my career in public service, it will be important to remember these experiences. As I serve it will be important that I try and engage with people in a way that affirms their humanity, showing them I truly care and that I want to understand them; the bedrock of good service must be connecting with individuals. I also must acknowledge that there will be times where I may need to help people, because they are not strong enough to do it on their own. When this occurs, I need to help blur the lines between helping and serving, making them feel comfortable, and not using my power in an unethical or harmful way. In acknowledging that people sometimes need helping or fixing, Nick, along with Amelia, set themselves up to inquire into the important question of how to intervene temporarily without signaling to people that they are incapable. This level of thinking can likely be accomplished more deeply by people who are approaching it holistically; by having thought about their own need for help, and the problems they found in being helped superficially, these students could have a different kind of stake in bringing effective, systematic help to others. Their thinking suggested demonstration of Connection and Empathy, in the South and West of the Model respectively.

A second important question was raised by Julia and Erin. They asked how organizations can systematically encourage service rather than fixing. Erin directly posed this question about scale: “Remen's article and this reflection paper assigned helping, fixing, or serving to many of my experiences. A question though is, how can you bring 
this kind of service to every person/patient/client you encounter?" This was a significant point because it suggested a readiness to think both systemically and theoretically about public service. This was a holistic mode of inquiry because these students navigated between their personal emotional responses, and the cognitive question of how the conditions that led to positive responses could be systematized.

\section{Implications of Findings from Narrative Part One}

Since Narrative Part One was primarily intended to create a foundation for the introduction of the re-engagement tool in Part Two, the implications of these findings are relatively straightforward. Students showed they could distinguish between fixing and serving and showed a strong understanding of why this distinction mattered. The value they placed on service created a solid foundation from which to proceed, as students would more likely be motivated to revise their own tendencies toward fixing. It seemed that the stage was set for students to reflect on the impacts of their serving (or fixing) and apply the tool as a means of growing in their capacity to serve. The groundwork was also laid for students to consider how their own leadership might contribute to more systematized service.

\section{Narrative Part Two: What Allows You to Serve?}

Building on their understanding of the fixing/serving distinction, this assignment walked students through the steps of using the re-engagement tool for Course Two. They were asked to identify and relate to an aspect of themselves that was "fixing," i.e. not free to serve (South). They were then asked to empathetically analyze the context of this experience and apply the NVC framework (West). They then were prompted to consider 
goals or visions for their service (East), and consider how meeting their needs might help them grow in their capacity to serve (North). The learning outcomes specifically were:

1. Students will demonstrate understanding of the helping/serving distinction through describing an example of their own past service.

2. Students will identify specific needs, based on reflection of their past experience of serving and fixing, that they must meet in order to serve effectively going forward.

3. Students will identify at least one step they can take toward meeting their needs in order to serve.

4. Students will describe what they can gain by meeting their needs for service.

\section{Results}

Like the Letter to Self assignment, which was Part Two of the narrative sequence in Course One, students were all able to accomplish the objectives at a basic level, but only some showed a deeper engagement with the prompts. The following points summarize the findings from analyzing the papers:

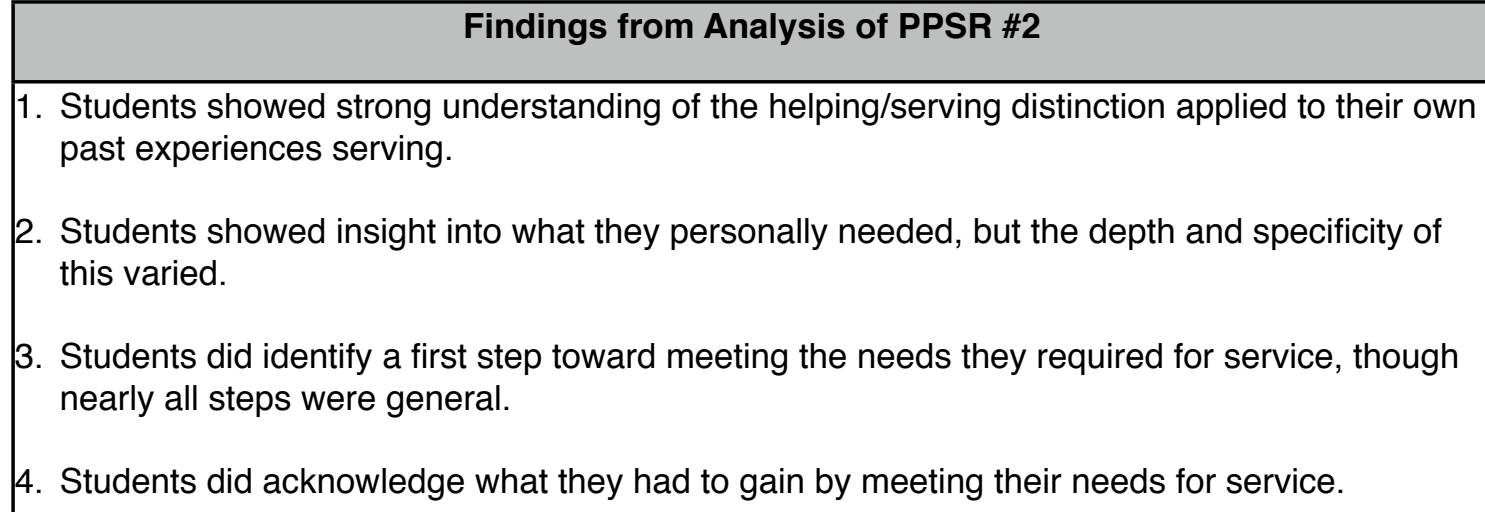

1. Students showed strong understanding of the helping/serving distinction applied to their own past experiences serving.

2. Students showed insight into what they personally needed, but the depth and specificity of this varied.

3. Students did identify a first step toward meeting the needs they required for service, though nearly all steps were general.

4. Students did acknowledge what they had to gain by meeting their needs for service.

\section{Students showed strong understanding of the helping/serving distinction applied to their own past experiences serving.}


All but one student showed a clear understanding of how to apply the serving/ fixing framework to their own service. One student showed only a basic level of understanding. Findings here included two themes: First, students showed honesty and apparent humility in reflecting on their own past challenges in serving. Second, students' treatment of their own experience "fixing" appeared thorough enough that they could apply serving/fixing analysis in future.

Overall, there appeared to be a high degree of honest reflection. Specifically, students acknowledged they had attempted to "fix" others and identified some of the underlying motivations. Nick wrote, “As I reflect back on those experiences, I can clearly tell the times that I have been in a disconnected, helping-mode.” He added that part of fixing was orienting toward extrinsic rather than intrinsic goals, for instance, to "be recognized as model AmeriCorps members." Erin similarly referred to her aim to "show off to my supervisors. Meredith gave details about her thoughts as she was in fixing mode: "I saw many of the individuals there and felt sorry for them and their circumstances. I saw them as broken and did not look at them from an optimistic point of view." Rachel went so far as to ignore the words "fixing" and "serving," and instead wrote about a parallel dichotomy — motivation from ego versus serving in humility. Nearly all students seemed ready and willing to acknowledge past experiences of fixing and often connected these to performative motivation.

Accompanying these acknowledgements was a solid understanding of the contrasting motivations underlying serving. Christopher described how fixing involved orienting toward external praise, writing that "I only cared about the recognition I 
received from fulfilling that role as an intern." In contrast, serving was about care for his younger sister as they both moved to foster care: "I poured all of my energy and love into making everyday $[s i c]$ better for her, and she shared her love and energy through this same connection, making every effort worthwhile." Julia made a clear distinction as well, and noted a power dynamic that came with fixing: "In that situation I knew that I had the upper hand, even if I didn't consciously think that. I knew that I was 'better' than them." Julia contrasted this to her experience of serving, in which she sought to contribute because of a relationship built and a desire to attend to a needed church community task.

Significantly, Julia included a self-compassionate analysis of her fixing: "It felt good to be wanted. It felt good that people had recognized my ability and looked up to me in that way." Though not everyone was as explicit, this honesty accompanied by selfforgiveness was common. It was significant because the willingness to self-critique is facilitated by self-compassion, and the assignment did not appear to elicit a self-shaming that would have been harmful. Shane, Amelia and Elizabeth all took an explicitly selfcompassionate lens in analyzing their fixing. Notably, these three all used therapeutic language, suggesting they had processed these experiences before. Amelia referred to the Karpman Triangle, Alexis mentioned Imago Relationships, and Elizabeth used the term "hustling for worth." I cannot know the extent to which therapy may have impacted students' capacity to analyze their fixing; it was very likely a factor but since all students met the learning objective, therapy was likely not the only reason for this. Ideally, an experience with therapy could help students self-compassionately self-critique, and be more ready for the expression of their gifts through public service. 


\section{Students showed insight into what they personally needed, but the depth and specificity of this varied.}

Drawing upon material on Nonviolent Communication, which emphasizes identifying the feelings and needs underlying behavior, students were to inquire into what needs they felt were necessary to meet in order to enhance their capacity for serving rather than fixing. In analyzing the writing assignments, I found that students varied in the depth of their engagement with this component. Five students met the competency at a high level, six met it at a basic level, three substituted advice for needs, and two did not meet the learning goal. Overall, students showed clarity in their understanding of needs as they relate to public service. The HCE goal is to become aware of needs in order to take responsibility and meet them, without holding others responsible for this. Through the HCE lens, doing so could increase efficacy and sustainability of civic engagement.

The two students who did not identify personal needs were Courtney and Christopher. Christopher wrote a thoughtful paper about how true service in general meets deep human needs. This understanding was relevant to the course, and likely helpful to Christopher, but it was not a specific analysis as I had assigned. Courtney wrote her paper about the needs of the students she worked with rather than her own.

The six students who met this learning goal at a solid level were able to identify relevant and important, though general, needs. For example, Meredith wrote about needs for respect and meaningful communication, and Nick discussed needing to understand the value and context for one's public service and see that one is contributing. Julia mentioned feeling appreciated and having a sense of belonging. She also created the term 
"equality-thinking" to refer to the need for working within a context that has an ethos of equity. Jonas named teamwork and humility, and Erin described a need for open communication that supported connection. This group of students generated useful insight about what they need in order to serve. Their more general understanding could help them in leadership roles in which they have power to facilitate these needs being widely met.

The third group of five students had a more specific quality to their identification of needs. They seemed to more directly tie their own unique experience to the articulation of their needs. For instance, Alexis mentioned closeness, appreciation, cooperation, inclusion, and belonging based on a direct analysis of past experiences. Marissa also had a more experience-specific need: "I need to include myself in the community to fully serve their need as well as mine." This came from her learning over various experiences with serving and fixing. Shane also revealed that they had thought through past experiences to get clear on motivation in service. They developed criteria for making decisions about service, to "only serve when sure of my purpose and when the purpose is one I've chosen to align myself with." This last group showed a strategic assessment of their needs specific to their own tendencies and service goals.

Finally, there was a flavor of big-picture and even grand descriptions of what students felt service could be if they could fully meet their needs. Amelia, though not the only one, gave the clearest example of this:

I felt at peace, having simply been a mirror — to reflect her own words and feelings back at her in ways she could see them differently — and a conduit for the 
love the universe has for her...I'm not sure how else to describe it. It was a spiritual moment, but I did not feel drained afterward; I was uplifted and at ease...So I must remember that they too have what I have, that we are equals in the eyes of the universe, and that it is not my job to fix their problems. I think if I am successful in this, I can meet not only my needs, but the needs of others, and I will be serving these individuals and my community in appropriate ways.

Amelia's statement resembled a benchmark. Along with Shane and others, she illustrated for herself a grand, but apparently authentic, vision of what service could feel like. It was aspirational, and so it would be important to treat it as such, rather than give up when a perfect aim is not reached. Though this could be a danger, Amelia's comments seemed more like a realization and opening to potential, than problematically attaching to a specific outcome.

\section{Students did identify a first step toward meeting the needs they required for service. Though mostly general, they seemed potentially meaningful.}

The majority of the group identified steps for themselves in meeting their needs for service. Courtney was the only student who did not, and Amelia and Mariah were the only students who gave concrete steps. More common examples of steps forward included: speaking up more, developing more background understanding of policy issues affecting service work, "wrangling" the ego, building relationships, being "of service to myself," valuing collaboration, and seeking connection. Students wrote that in taking these steps they would step into a "positive cycle of service," continuing to serve in ways they both enjoyed and had community impact. 
Mariah's paper showed an example of how the process of reflection could open up more capacity and courage to serve, as well as strategic steps on how to do so:

One specific example would be that I have been wanting to get more involved at church here, yet I have been too afraid that my past experiences will be repeated. Keeping my reflections in mind, I think it would be helpful to start off with a consistent, low-pressure service role. In addition, I think I need to make sure there are people I can trust within the place I want to serve. This may require having conversations with leaders of different churches to find if they share the same passions and values as me. With my needs being met in the future, I am hoping in church to not only foster a real community of depth and intentionality, but also start social justice initiatives, especially to support immigrants and refugees.

Though with Mariah's example, it seems more likely she will follow through on her insight, with others, we cannot know how significant this assignment was. It seems possible that some of the realizations could indeed support students in more purposeful and sustainable service.

\section{Students did acknowledge what they had to gain by meeting their needs for service.}

The final learning objective was for students to consider the stakes and ideally invest in this kind of needs-thinking more in future. The ideal was for students to realize that giving their gifts depends on meeting their needs. In doing so, they could step into a flow of need and gift that could be very sustaining, as well as potentially beneficial to others. 
Most students gave a brief but seemingly genuine statement about their desire to increase their capacity for this kind of service. Meredith's example is illustrative:

I recognize that I am an introvert and there are times that I find it very hard to step outside of my comfort zone to serve. I need to imagine the possibilities of the experience rather than focusing on the negative what ifs. For example, I have a strong passion for advocacy on education reform and social justice issues and have a need to feel heard but I don't always speak up on those issues for fear of confrontation. Finding a way to step outside of my comfort zone and use my voice is a step in the right direction.

Meredith referred to the benefit of facing her fears, but others named the potential positive outcomes more explicitly. Nick wrote, "The service I'll do can be fulfilling and renewing to me, and meaningful and validating to those who I'm working with. It would be authentic, because I would really understand the value of my work." Nick's benchmark seemed a potentially valuable result he could draw on in future.

Finally, Erin hinted at a larger scale benefit from bringing more discernment to how we perform service. An aspiring health professional, she noted that she sees a "healer" as someone who connects and serves through that connection. Then, she scaled this idea up:

I think this is how the leaders of our communities should practice, by becoming healers of the communities they serve. It would be interesting to see how different our community would be if we trusted our leaders like we trusted our healers, and I believe the transition from helpers/fixers to servers is a step toward that. 
Erin's comment suggested that some students were likely internalizing the concept of serving versus fixing, applying this not only to their own past and future, but to what they could imagine as possible in the wider community.

\section{Implications of Findings from Narrative Part Two}

Overall, implementing the re-engagement tool in Course Two appeared to be effective. Students largely "landed" successfully on the stages of the tool and showed they were reflecting as the tool prompted. Nearly everyone achieved the aim in the South to "Identify and relate to aspects of self not free to serve." They described their past experiences of fixing, largely with compassion, and often with an indication such as Nick's, that the distinction between his own serving and fixing was stark. As students moved into the West, they were generally able to name specific needs. This could be supported in future by creating a video to substitute for the Course One in-class activity to practice with Nonviolent Communication. In the West, students brought enough "Empathetic analysis and discernment of feelings and needs" to their past "selves" that they were able to gain useful information to propel them forward with the tool. In the East, students were prompted to work with civic vision through considering a context in which they wanted to serve. Embedded in this context was their vision for public service, in which students revealed that their visions for service included the chance to be of real benefit to communities. Finally, in the North, students' essays did indicate "Growth in capacity to use gifts, in service of vision, in the civic sphere." They acknowledged what they had to gain by meeting their needs, and some students spoke to the collective benefit 
this could bring as well. Generally speaking, it seemed that students in Course Two successfully utilized the tool to grow in their engagement capacity.

\section{Weekly Discussion Posts: Deepening Understandings of Service}

Each week, students responded to four prompts: (1) summarize the readings, (2) identify a significant quote and explain why you selected it, (3) articulate what would be relevant about the readings for an engaged public servant, and (4) explain how the readings shed light on an experience you had as a citizen or a public servant. In sum, after relaying key points from readings, students were to apply the theories to an experience and generate new insight.

\section{Results}

In order to analyze the data generated from students' weekly reading responses, I re-read them and noted where students showed evidence of learning, or not, toward the four learning outcomes. After collecting long lists of quotes that shed light on this, I sorted the quotes into themes. After re-reading these lists sorted by theme, I memoed to distill the themes further. I then combined the themes into four key findings, which are summarized below. 


\section{Findings from Analysis of Weekly Reading Responses}

1. Most students' writing suggested an alignment and connection with the New Public Service framework.

2. Most students named personal insights about how they had been thinking or acting unconsciously in relation to public service, and expressed desire to change.

3. Most students wrote that their personal commitment to service had refined and increased based on digesting the theories.

4. Some students' writing showed holistic engagement with learning about public service; they wrote about the connections between the emotional, mental and sometimes, the spiritual components, of public service.

5. Five out of 16 students showed little evidence of meaningfully engaging with the reflection goals.

6. One highly reflective "outlier" student struggled to connect to the trust and hope that support service.

\section{Students' writing suggested an alignment and connection with the New Public Service framework.}

The first finding from these reading responses was that most students understood, and seemed to adopt the perspective of, New Public Service. In aligning themselves with NPS, students also aligned with the civic republican values underpinning it. They noted in many posts how adopting the NPS framework could lead to more desirable outcomes on political, economic, and interpersonal levels. It is important to note that we cannot be certain of students' true views; the course clearly positioned itself as advocating for NPS and students would have incentive to claim allegiance to NPS. Part of the data analysis process included an attempt to discern where students made authentic statements that reflected true learning. Overall, I noted that while a few pro-NPS statements were brief and declarative — and potentially not authentic — most were more descriptive, personal, and seemed to be written in students' natural, apparently honest, language. 
One example of this came from Erin, who adopted the civic republican argument that the decisions of citizens should be made with reference to the common good, not self-interest. She referred to the capacity to think beyond self-interest, and especially beyond personal certainty and righteousness. Responding to an article about political polarization, Erin wrote, "I think once we recognize [a tendency toward righteousness] in ourselves, we can then move forward to becoming a stronger citizenry. To do this we have to move from our selfish needs to the need of our community or the big picture.” By emphasizing the importance of self-examination in her statement, Erin also took an implicitly holistic view; she thought the mental work of critical self-reflection could lead to a more generous (affective) perspective.

A second example came from Nick, who wrote about the core NPS assertion that public policy should emerge from a constructive collaboration between citizens rather than simply the interests of the majority or the demands of the market. Nick wrote about the importance of "discourse, consensus, community building, participation, and equality," adding that, "We have to find a way to synthesize everyone's thoughts into action that's beneficial for the whole, and a big part of that is the intentional effort of people in the public sector to give citizens a platform, and to listen to them." In this post and others, Nick often used the phrase, "As public servants, we need to...” Many students echoed this language in their posts, referring to their service work experiences, their intentions to work in public service, or the relevance of their major to Public Administration. Some students used phrases such as “As citizens, we should...” An example of this was from Mariah who wrote in Week Three, "As citizens in a democracy 
we all should have the opportunity to create our society together." Because of this more personalized and opinion-centered content, I interpreted these statements to be largely reflective of thought and learning, in addition to serving students' aims of course success.

A final example of seemingly genuine investment in the NPS perspective emerged from Jonas, who wrote three posts touching on his frustration that market-based thinking so strongly impacted policy. Jonas wrote in Week Four that "the push for the market vision has blinded us from important community issues and we must work together to combat the tragedies of the commons for the benefit of all." The following week, he continued along these humanist lines, adding an environmental theme in responding to an assigned text by the Dalai Lama: "The disconnect with the natural world and notion of being above it has brought us to the state of the world at present." Furthermore, "previous forms of administration have excluded the human factor, creating a rational model which is [in]human." One week later, Jonas seemed to be thinking at the level of mental models, especially about the competition inherent in market-based logic. He wrote:

Our history celebrates men that have been ruthless and used violence to conquer territories and people. We all came from women though, and in our first months of life, our mothers gave us love and nourishment. This is the compassion that we should feel for one another and the world.

He concluded that "We have seen what the consequences of this "destructive competition" in a world with grave environmental problems and social injustices." Jonas moved from discussing the importance of community, to the value of nature connection, to the harm caused by exclusively rational thinking, to the damage caused by an ethos of 
individualism and competition. Jonas's posts showed an engagement with the ethos and spirit of NPS, and a seeming commitment to confront and move past the core mental models he thought were causing systemic harm.

\section{Most students named personal insights about how they had been thinking or acting unconsciously in relation to public service, and expressed desire to change.}

Students referred to their motivation to self-reflect and to change some of their mental habits in order to be effective public servants. They referred to mindsets that aligned with market-based or hierarchical thinking about public service. Erin identified this simply, referring to an author's honest quote admitting to and critiquing her own righteous thinking: "The honesty behind this quote allows the reader to bring forward the possible thoughts of their subconscious mind." Erin implied here that she wanted to unveil her own assumptions, and found the goal of public service worthy of a process that many might avoid.

For several other students, the willingness to self-reflect manifested differently. They referred to the status quo in society, acknowledged they wished for a more connected society, and owned up to having a role in making this happen. Mariah wrote of her wish for "authentic community" characterized by "wholeness, diversity, caring, trust, and teamwork." But Mariah did not stop with wishing. She honestly acknowledged both that "I am not fully stepping into my rights and potential as a citizen — an owner, not just a consumer," and that "I too often slip into objectifying other people based on their views, rather than seeing them as complex humans with emotions just like me." Mariah drew on her own willingness to self-reflect to become more clear on what she wanted and 
what she would need to do to achieve that. Given that Mariah wanted community and "potent service," her willingness to look at herself was significant. Christopher shared a similar level of honesty, writing that in his life,

I enjoy reading and debating about current events and political theory. As such, I find myself very narrow-minded in all such conversations, seeking affirmation following an argument rather that listening closely to understand their point of view.

Following this reflection, Christopher added, "Listening to and respecting members of one's community is an essential skill for a public servant. Any effective public servant must learn to move past bias and stereotypical beliefs in order to best serve." Though not everyone engaged as honestly as Mariah and Christopher, their writing assignments indicated a potential in this HCE curriculum to spur students in connecting cognitive and emotional engagement, and to open up new political possibilities for themselves.

\section{Some students wrote that their personal commitment to service had been refined and increased based on digesting the theories.}

Many students included periodically in their posts statements containing phrases

such as "I realized," "I liked," "I want to," or "I think I need to." They seemed to express willingness not only to self-reflect, but to apply this to their thinking about their future work. For instance, Alexis wrote in week three that an NPS framing of service had personal significance: "I really liked when the reading talked about public servants being people who are professional citizens, where the common good is their specialty, that is definitely in alignment with what I want to do with my life." Along similar lines, Nick 
wrote over email to me, "Also, thanks for having us read the excerpt from 'People Are Hard to Hate...' I think it was something that I needed to read" (Personal Communication, April 17, 2019). Nick seemed to be drawing upon course materials to spur reflection that he implied would lead to some growth. It is important to note that not all students made these kinds of statements (see Finding 5), and students varied in their frequency of this. However, some statements appeared to indicate a strengthening of service commitment. An atypical but significant example of this pattern of making statements of personal commitment in reading posts came from Mariah, an engaged student who made the rare effort to meet with me in person when she found herself feeling disconnected from the class in Week Three. In Week Six, Mariah wrote of the Dalai Lama text that: this book is reminding me of the power I could have if I acted more. I am beginning to see myself as a lot more powerful than a tiny speck in this giant world that will never be able to make waves in our giant government. The section in this chapter on women in leadership was particularly encouraging to me. Mariah seemed willing to let herself be moved into a more expansive view of her capacity. Two weeks later, she continued in this vein, writing, "I think that I still have an old definition of leadership, and I have some reframing to do. This is probably one of the things hindering me from stepping into my full role [in movements]." Specifically, she added, "I do not see myself as being as powerful or as responsible as those who I see as 'leaders.' I think restructuring my conceptions of myself and those 'in power' will be beneficial." We cannot know how Mariah followed up on these statements, but her intentions, stemming from critique and insight, seemed to hold the potential for growth. 


\section{Some students' writing showed holistic engagement with learning about public service; they wrote about the connections between the emotional, mental and sometimes, the spiritual components of public service.}

Though they were not always explicit, some students showed through their reading responses that they were thinking holistically about public service. Their writing drew implicit connections that suggested students took for granted some interplay between the dimensions. This mirrored the theory of New Public Service (NPS), which emphasizes the relevance of many emotional components of service such as empathy and connection. Students often assumed the preferability of civic republican values such as seeking the public good, rather than liberal values such as personal freedom. In doing so, they blurred the lines between cognitive, emotional and spiritual dimensions. They wrote about conviction and critique, emotional investment, and trust in unseen connectedness, and they often did so without distinguishing between these modes. The exception was the $25 \%$ of students who distinguished them by tacitly avoiding the emotional and spiritual.

Most students were implicit in their connections between the emotional and cognitive dimensions. Nick, however, noted this directly, stating his stance that NPS's inclusion of emotional logic made it more complete:

I think that the Postmodernist's [sic] desire to take into account 'values... subjective human meaning... [and] the full range of human emotions in the analysis of behavior' is an important and unique aspect of the New Public Service...Other approaches to administration tried to justify their approaches with an inaccurate view of human behavior in the rational model. This is a clear difference, and one that makes NPS more legitimate. 
Two other students made implicit statements about the connection between holistic dimensions. Mariah wrote in response to a text by the Dalai Lama about the need for Millennial generation activism: "This phrase 'existing is coexisting' will stick with me. This is what NPS and the Revolution of Compassion are all about! It all comes back to connection, relationship, and community." For Mariah, the principle of interconnection tied directly to the tenets of New Public Service. Alexis wrote about their experience of service as something that created deep connection between people. They wrote in response to Remen's (1998) statement that "our service strengthens us as well as others," that:

These words reflect how I feel when offering care to those I love, regarding their humanness as my own. This sentiment has also been particularly helpful for me as a person (or citizen) when regarding forgiveness, knowing that we are all human and that support and service are healing forces...it is crucial that people understand how the dynamic needs to shift in how we care for others, if we want to empower one another and move forward.

Alexis moved from mentioning love and forgiveness on a personal level to talking about them on a community level. Service was the thread that connected interpersonal care and social change. Students tended throughout the term to write about the importance of emotional competencies for public servants.

In addition to the examples given in the first three Findings sections, three students discussed the spiritual dimensions of civic leadership, as I have defined them. In 
Week Seven, Justina gave her analysis of the relevance of compassion for public servants, tying this to the important concept of accountability:

Holding people accountable and being compassionate requires you to be contradictory and work in ways that are still true...Compassion is a deep awareness of the suffering of another coupled with the wish to relieve it. Accountability is being called to account, you must be answerable...both accountability and compassion take time, energy, and patience. It needs to be compassion AND accountability, not compassion OR accountability.

Justina's post attempted to reconcile what could seem like the paradoxical importance of both compassion and accountability. She seemed to be coming to understand that compassion is not equivalent to indulgence. The conception of a public servant as someone who holds others accountable out of regard rather than contempt, and out of a deep confidence in others' capacity, is directly aligned with the HCE conception of service as an expression of care and trust in a larger process.

Christopher and Nick wrote about the pleasures and benefits of what I consider here as a spiritual dimension of civic leadership, interconnection. Christopher wrote, "It is a strange and pleasant power to watch the results of one's act of compassion towards another," and "acts of unbiased compassion...hopefully encourage future acts of compassion originating by those you once encountered." This statement suggested a conception of compassionate leadership as being beneficial and enjoyable, rather than exhausting. It suggested thinking about service in the "gift framework," in which community members give freely, not out of obligation, but from the pleasure of being 
generous and the desire to live in a resource-rich and abundant community. Nick likely

revealed similar thinking when he wrote about the Dalai Lama's statement that: "You will find that by doing good to others, you are doing good to yourself thanks to the principle of interdependence" (Dalai Lama, 2017, p. 51). Nick explained, "I think people are uncomfortable with the idea that a reason to do good is because it's good for yourself." And yet, "that reason can help one realize other ways that doing good is good. Thinking about how we are interdependent is a good place to start too." In considering different motivations to serve, Nick seemed to realize that martyrdom was undesirable. He appeared to connect instead with an HCE-aligned goal of serving in a manner that is sustainable, trusting, surrendered, and collaborative.

\section{Five out of $\mathbf{1 6}$ students showed little evidence of meaningfully engaging with the reflection goals; they responded to the prompts but deflected the deeper inquiry.}

Five students, in five unique ways, showed less evidence of engaging more deeply, and the above findings rarely applied to them. Their responses inform the secondary research question What learning did students demonstrate in relation to holistic civic engagement capacities and competencies? It is important to consider how the curriculum impacted all students. Though these five students engaged more deeply with the core narrative sequence, their responses to the weekly reading prompts were less reflective.

First, Rachel showed a pattern of relating very concretely or not relating at all to the themes from the readings. She often ignored the last prompt in the assignment, which asked students to write about how the theory applied to experience. Second, Sarah was 
consistently brief in her posts, writing the minimum amount to summarize the readings and usually avoided the last prompt about application as well. Sarah wrote about her deep commitment to public service, stemming from her own positive experience as a client accepting services. But when invited to self-reflect and refine her own motivations for service, Sarah refrained. Third, Meredith responded fully to the prompts, but refrained as well from self-reflection. She applied the NPS framework throughout, and noted the importance of non-judgment, care, and respect in service, but she only wrote about her personal engagement with becoming this kind of public servant in the reflection papers. Fourthly, Shane wrote brief posts that sometimes took a harsh tone when referring to their own past mistakes, and generally refrained from discussing personal growth in relation to public service. Finally, Courtney consistently did not seem to reflect on her own motivation for service, even in the papers that explicitly asked for this. She was the only one to do this in papers. In reading posts, Courtney used examples that suggested she was thinking about service from a more transactional viewpoint—based on what was observed, rather than what was experienced on deeper levels. These five students completed assignments; they were not "no-shows" as some often are in online courses, but for some reason, they did not choose, or were not able, to reflect as most others did.

\section{One highly reflective "outlier" student struggled to connect to the trust and hope that support service.}

One final finding to report in this section came from Amelia. Amelia engaged deeply with the self-reflection component of the course, emailing me to express appreciation for assigning the Dalai Lama text. She had read it twice already, found it to 
be a source of hope, and kept it always in her purse. Relatedly, Amelia wrote over the first half of the course about both her skepticism and her struggle to maintain basic hope. She wrote in Week Five about the authors of the New Public Service text:

Excuse my frustration (again), but the more I read this book, the more I realize the Denhardts are not living in our current era. I sincerely long for their time, when the idea that everyone might just 'keep everything above board' was possible, but I understand that that's just not where we are anymore. We live in times where people believe the lies they're fed and the divisions that are being drawn, and millions can't quite figure out that the only side that matters is where the money is.

Amelia, a student in her late thirties with years of work experience abroad, was understandably skeptical. The Obama-era text did address the problems Amelia alluded to, but the authors did not center these issues. Amelia had written in her introduction that she planned a career in industry, but decided to engage with public service after the 2016 election. Amelia seemed ready for deeply critical readings that would give her theoretical background to make sense of the patterns she was observing in national politics.

\section{Implications of Findings from Weekly Readings Responses}

The reading response assignment was not part of implementing the re-engagement tool. These data do, however, speak to overall student learning toward the Course Two themes of public service theory and practice. It is important, in implementing holistic curriculum design, to assess cognitive learning and comprehension of theories for two reasons. First, theory is an important content and cognitive aim of higher education. It is 
useful to assess theoretical learning in an HCEE course to assure that emotional and spiritual learning are not eclipsing cognitive learning. Second, theory can be seen to have a liberating and transformative impact on learners (hooks, 1994). In the context of civic engagement education, theory and critical insight can help students carve out mental space from limiting assumptions and world views, and see themselves in a more empowered light. Based on these findings, it seems that students did comprehend the theory of New Public Service. Furthermore, it seemed that they also applied this cognitive learning holistically to reflect on their emotional responses and behaviors, indicating that some transformative learning occurred.

Examples of this substantive engagement with theory came from Jonas, for instance, who reflected on the "inaccurate view of human behavior in the rational model," and then went on to note the value of nature connection and care. We also so Christopher reflect on his patter of being "narrow-minded in all such conversations," and expressing a commitment to a more open and generative approach. We saw Mariah realize that she was not "fully stepping into my rights and potential as a citizen," and seeing herself as an owner of democracy, "not just a consumer." Erin expressed the commitment to recognize righteousness within the self, as part of moving toward the common good. Justina wrote about the importance of compassion as coexisting with accountability and enforcement. Finally, Nick and Christopher drew on the readings to consider the HCEE competency of Interconnection and its role in sustainable public service. Overall, many students drew on New Public Service and other theories in a way 
that demonstrated their cognitive comprehension, as well as their capacity to let those theories into their own minds and hearts in a way that appeared transformative.

In considering the implications of the finding that five students typically did not reflect very deeply, it is useful to consider measures that could be taken going forward. These measures could include (1) more thorough explication of the prompts to clarify the reflective aims, (2) more personal email communication to encourage students who show an initial shyness in their reflections, and (3) considering a hybrid, rather than fullyonline, format in order to model compassionate self-reflection in person. In sum, the weekly reading posts, though they did not speak to the efficacy of the re-engagement tool, did provide useful insight into the cognitive and transformative learning achieved by students in the HCEE course.

\section{Conclusion}

The results of the study suggest that the re-engagement tool is a promising strategy for teaching holistic civic engagement. Before moving to a broader discussion of the applicability of the tool and model, it is useful to highlight two key points about the findings reported here. First, the core premises of the tool seemed to match student experience and need. Second, we saw an array of indications that the tool had, for many, served its core purpose of increasing students' capacity for engagement.

First, the results indicated that the core premise of the tool—that past experiences of disengagement create a problem for engagement—seemed appropriate based on student responses. In Course One, students identified important impacts from past experiences of disengagement - they mentioned losing some of their access to qualities 
such as "having a voice," a core sense of hope, and an ability to look at the world "like all people were good and act on it." Students in Course One also commented, unprompted, upon the significance of the impacts of disengaging experiences. In Course Two, students showed a readiness for reflecting upon their own "fixing" so that they could move more fully into service. It seemed that the tool could respond to students' own goals to serve more fully and effectively. Furthermore, the disengagement and fixing that students described was apparently impeding their civic and public lives.

Second, we saw an array of indications that the tool had served its core purpose of increasing students' capacity for engagement. Many students wrote about key shifts in perspective and commitment that could enable this increased capacity. In Course One, we saw this in Carla's final essay: "Inequality thinking is unfortunately inside me...There are norms I don't think I believe in, but I am always skewed." Carla and others used these realizations to open to new, more empowered, views about themselves and their civic capacity such as trusting and valuing one's own political voice. In Course Two, we saw Mariah write that "I think that I still have an old definition of leadership, and I have some reframing to do" and that "restructuring my conceptions of myself and those 'in power' will be beneficial." A second premise of the tool is that disengagement can be ameliorated by reflecting on the past from an empowered perspective that includes selfempathy and vision. Student work in both courses demonstrated this self-empathy, seen in rich descriptions of past experiences, and vision, seen in students' commitment to engagement and service in their communities. Most, though not all, students showed that they had the ability to deeply engage with the process of the tool, and reaped rewards 
from this effort. The following chapter discusses the implications of the study for undergraduate civic engagement education. 


\section{Chapter Five: Discussion}

This chapter discusses (1) the significance of the findings, (2) learnings about the Model of Holistic Civic Engagement Education and the re-engagement tool, (3) broader implications of the study, and (4) important directions for further study.

\section{Significance of the Findings}

The research questions asked: (1) How does writing a sequence of engagement/ service personal narratives impact undergraduates' capacity for holistic civic engagement? (2) What learning did students demonstrate in relation to holistic civic engagement capacities and competencies? Overall, implementing the Model and teaching students to use the re-engagement tool through the essay prompts yielded promising results. Students seemed to arrive at deeper levels of awareness and clarity that had the potential to impact their future engagement and service. Additionally, students demonstrated learning in relation to the holistic civic engagement capacities and competencies. Conducting the study also revealed areas for development, such as the need to bring more explicitly critical perspectives into the curriculum. Finally, the study revealed some parameters that would be important for future implementation, such as inperson sessions included in online courses.

\section{Demonstration of the HCEE Competencies and Capacities}

The second research question was What learning did students demonstrate in relation to holistic civic engagement capacities and competencies? The following summary of the analysis of student work suggests that in working with the tool, students 
demonstrated the competencies and capacities. The study also revealed where more support or emphasis could be placed in future.

In the East, students demonstrated Vision in their essays as they discussed general visions for democratic culture (e.g. trust), visions of their own specific contributions to civic life, visions of what would be possible for their public service as they met more personal needs, and, in some cases, visions of their own wholeness after re-engaging. Students showed evidence of Critical Insight in their application of readings to the reengagement of their disengaged "selves," which brought fresh insight and perspective to the context of the disengagement. We also saw this competency in their comprehension and self-reflection around the New Public Service theory, a framework that critiques other models of service. This seemed to allow students to carve out some mental space from limiting assumptions and world views, and see themselves in a more empowered light. In using these competencies, students also showed they could Generate or receive civic visions in the context of democracy.

In the South, students demonstrated Connection as they worked with the tool to connect to their own past experiences. In the in-person course, students wrote in their post-assessments that they valued the connections they made in the course. In their writing, students richly described their past experiences of disengagement and fixing. In building this internal connection as they followed the tool's reflective prompts, students also demonstrated ability to Identify Skills and Interests. This second competency was seen in students' consideration of the specific gifts they would wish to give once reengaged. Students wrote about their particular intentions for service, or how they could 
use personal qualities in their civic lives. As part of using these competencies, students showed some of the capacity to Relate to vision, self and others. The tool was focused on internal relating with the implicit assumption that self-awareness could allow for more connection with others. This is an area for exploration and it would be important to assess going forward whether this assumption is accurate.

In the West, the competencies were particularly apparent as the tool most explicitly elicited them. Students demonstrated Empathy through relating to their past "selves" and naming their past feelings, experiences, and needs, typically in a generous and compassionate way. They demonstrated Engagement as they considered those feelings and needs and responded to them by providing context from readings, and by considering how those needs could be met in future. Similarly to the capacity in the South, students did show evidence that they could Engage from compassionate discernment and learn from experience. They did this by going "below the surface" of disengagement and fixing to discern what deeper factors were shaping these experiences. They learned from this experience by reflecting upon it and reframing it for themselves. It is important to note that this learning was within the context of the course and the implementation of the tool. The assumption implicit in the tool design is that the habit of mind students build by learning to look under the surface of their own behavior could extend to their understanding of community issues. The intent is that students can learn from the tool how to respond to deeper motivations in themselves and others and thus be more effective in civic engagement. However, further study is needed to assess how well 
students were able, after taking the course, to apply this discernment and learning to their civic lives.

Finally, in the North students demonstrated Interconnection in their desire to contribute and deploy new capacity they gained through re-engaging to their civic and public work. While students, especially in Course Two, arrived with a high motivation to serve, their discussions of the value of service in light of the course readings did suggest that this motivation grew further. In working, through the tool, to align with serving rather than fixing, students were aligning more fully with a view of service in which interconnectedness is implicit. In Course Two, many essays showed a sense of desiring to contribute to a larger whole. Students showed Trust in their growing confidence that their efforts could be fruitful. In Course One, students appeared to grow in their understanding of the importance of strategy and sustained effort as key to civic leadership. This demonstrated Trust because committing to longer term efforts can require trust in a longer process. Further, Trust was often embedded in students' articulation of their civic visions; they indicated the value of trusting in other citizens and committing to collaborative processes. As with the South and West capacities, this study assesses a likelihood or apparent increase in capacity to Use gifts in context of vision, relationships and discernment (in civic world). Students did show an apparent increase in capacity for engagement, seen in their references to realizations about their potential and in their plans. Further study and long-term investigation is needed to assess how students can express this capacity in the civic world. 


\section{Impact of the Core Narrative Sequence}

The first research question asked, How does writing a sequence of engagement/ service personal narratives impact undergraduates' capacity for holistic civic engagement? Table 5.1 lists three summary findings in response to this question based on the specific findings from Chapter Four. Synthesizing the promising outcomes from the study allows us to better build upon what appeared to be effective in developing students' capacity for civic engagement.

Table 5.1: Key Findings

\begin{tabular}{|c|c|}
\hline Key Findings & Specific Findings \\
\hline $\begin{array}{l}\text { Key Finding 1: } \\
\text { The re- } \\
\text { engagement tool } \\
\text { appeared relevant } \\
\text { in addressing } \\
\text { issues with } \\
\text { engagement. }\end{array}$ & $\begin{array}{l}\text { 1. Students acknowledged the seriousness of past experiences in shaping } \\
\text { their later behavior. (Course One) } \\
\text { 2. Students noted that disengagement often was the result of not feeling } \\
\text { valued as a person. (Course One) } \\
\text { 3. Some students identified their personal disengagement as relating to } \\
\text { their public/political behavior. (Course One) } \\
\text { 4. Some students found the assignment to be powerful or impactful. } \\
\text { (Course One) } \\
\text { 5. Students all showed evidence of understanding the difference between } \\
\text { fixing and serving. (Course Two) } \\
\text { 6. Nearly all students expressed a commitment to serve (and not "fix"). } \\
\text { (Course Two) } \\
\text { 7. Some students also furthered this by wondering how service could } \\
\text { become a system-wide norm. (Course Two) }\end{array}$ \\
\hline
\end{tabular}




\begin{tabular}{|c|c|}
\hline Key & Specin \\
\hline \begin{tabular}{|l|} 
Key Finding 2: \\
The narrative \\
sequence seemed \\
largely effective in \\
guiding students \\
to a new level of \\
awareness that \\
could serve their \\
future civic \\
engagement.
\end{tabular} & $\begin{array}{l}\text { 1. Most students demonstrated ability to follow their empathetic analysis } \\
\text { with relevant insight that seemed to lead toward re-engagement. (Course } \\
\text { One) } \\
\text { 2. A smaller group demonstrated the above two capacities as well as the } \\
\text { ability to invoke a meaningful vision in order to re-engage in a specific } \\
\text { and directed way. (Course One) } \\
\text { 3. Most students were able to respond to challenges somewhat } \\
\text { empathetically by affirming the importance of their goal. Four students } \\
\text { were able to relate with skill to their challenges and appear to reach a } \\
\text { new level of insight that could open new possibilities for engagement. } \\
\text { (Course One) } \\
\text { 4. Students showed strong understanding of the helping/serving distinction } \\
\text { applied to their own past experiences serving. (Course Two) } \\
\text { 5. Students showed insight into what they personally needed, but the depth } \\
\text { and specificity of this varied. (Course Two) } \\
\text { 6. Students did identify a first step toward meeting the needs they required } \\
\text { for service, though nearly all steps were general. (Course Two) } \\
\text { 7. Students did acknowledge what they had to gain by meeting their needs } \\
\text { for service. (Course Two) }\end{array}$ \\
\hline $\begin{array}{l}\text { Key Finding 3: } \\
\text { There did not } \\
\text { appear to be a } \\
\text { cost to } \\
\text { implementing the } \\
\text { Model. }\end{array}$ & $\begin{array}{l}\text { 1. All students identified appropriate general civic visions. Several } \\
\text { students were able to articulate specific visions. (Course One) } \\
\text { 2. Nearly all students identified leadership qualities that aligned with } \\
\text { course/PA conceptions of democratic leadership. (Course One) } \\
\text { 3. PA } 311 \text { Post-Assessment showed learning about civic engagement that } \\
\text { was typical compared to previous versions of the course. (Course One) } \\
\text { 4. PA } 311 \text { Reflection on Class Community suggested that the added } \\
\text { vulnerability of the re-engagement tool did not result in inappropriate } \\
\text { discomfort. (Course One) } \\
\text { 5. Most students' writing suggested an alignment and connection with the } \\
\text { New Public Service framework. (Course Two) } \\
\text { 6. Most students named personal insights about how they had been } \\
\text { thinking or acting unconsciously in relation to public service, and } \\
\text { expressed desire to change. (Course Two) } \\
\text { 7. Most students wrote that their personal commitment to service had } \\
\text { refined and increased based on digesting the theories. (Course Two) }\end{array}$ \\
\hline
\end{tabular}


Key Finding 1: The re-engagement tool appeared relevant in addressing issues with engagement.

Based on students' essays, the Tool seemed to respond to students' life experience. In Course One, the first part of the narrative sequence asked students to describe experiences of disengagement. Analysis suggested that disengagement often resulted from not feeling valued as a person. Engagement often resulted from a caring relationship or experience of inclusion. The re-engagement tool, presented in the following assignment, mirrored this by teaching students a mode for explicitly valuing themselves and coming into caring relationship with themselves. One of the key elements of the reengagement tool is that it guides students through maintaining an awareness of themselves as compassionate listener/responder while naming what was felt and needed during a disengaging experience. In this sense, the Tool, when used effectively, could augment a student's capacity to re-engage, through empowering the student to take on the role of that caring other. Similarly, in Course Two, students described their experiences of attempting to "fix" as times during which they lacked awareness, perspective, and key resources. The tool asked them to address this lack, to take responsibility for their own service by proactively meeting their personal needs. The tool seemed, overall, to be responsive and relevant to the experiences of disengagement and fixing that students reported.

Key Finding 2: The narrative sequence seemed largely effective in guiding students to a new level of awareness and/or capacity that could serve their future civic engagement.

Students' writing pointed to a seriousness about their disengagement, a real desire to re-engage, and often to an appearance of a shift in engagement capacity. While the 
evidence in Chapter Four speaks to this more fully, two key illustrations of this from Course One are worth reiterating here. Josue wrote "I need something back from you that I think I've lost along the way...I really need that sense of standing up for myself to come back...If we got this skill of not caring what people think of us back, I feel that we would...get more into our stretch zone." Similarly, Carla's essay showed a desire to reorient to the past experience and move forward with more capacity: "This event took so much positivity and excitement from you...I want to bring back that positive happy person that wants to make a positive difference in people's lives to help to be better civically engaged now." Furthermore, students in Course One supplied political implications of their increased capacity. They named a reorientation to, or sense of growth in, their commitment to dialogue, speaking honestly despite power dynamics, finding hope, and empathizing with those holding opposing views. We cannot know without collecting ongoing data to what extent students reintegrated these aspects of themselves. Based on their writing, however, it does appear that students took a first step: They moved cognitively and emotionally back into experiences that had created patterns of disengagement, and by reflecting, empathizing, and imagining new possibilities, increased the possibility for new patterns of engagement to take hold.

In Course Two, the re-engagement tool was aimed at helping students shed light upon what may have caused them to "fix" rather than serve in the past, and to commit anew to meeting their own needs in order to serve. Students were very open about their own past fixing, and the majority seemed to gain insight about serving that could help them do so more consistently going forward. They seemed honest in relating the needs 
they would need to meet, and appeared earnest in wanting to meet those needs to serve well. They showed that they could articulate the stakes of serving versus fixing, both generally in terms of the impact on the field of public service, and in their own lives. Additionally, students in Course Two wrote about increased motivation to self-reflect and to update their mental habits - beyond market-based or hierarchical thinking about public service - to be more effective public servants.

Key Finding 3: There did not appear to be a cost to implementing the Model.

In order to continue implementing and studying the Model going forward, it was important to establish whether or not its use detracted from student learning in any way. Based on post-assessments, written assignments, and final essays in both courses, there was no apparent decrease or unmet expectation in academic attainment. Students showed learning about the theories, the qualities of public leadership, and other course content. There was evidence of avoiding some of the reflective components of Course Two, but not of harm, or of missing out on the other academic content. Furthermore, based on their reporting about their experience of the course environments, no student reported issues with discomfort, even as the narrative sequence potentially increased the vulnerability of participating in the course. Importantly, students' anonymous evaluations also did not report any issues with the narrative sequence. 


\section{Areas for Development}

Table 5.2: Summary of Findings Suggesting Areas for Development

\begin{tabular}{|l|l|}
\hline & \\
\hline Area for Development 1: & $\begin{array}{l}\text { 1. Nearly all students discussed engagement as a result of } \\
\text { moving through a challenge. Engagement was often framed } \\
\text { as a feeling of contribution or investment that was earned } \\
\text { through struggle. (Course One) }\end{array}$ \\
$\begin{array}{l}\text { Material could support } \\
\text { student re-engagement }\end{array}$ & $\begin{array}{l}\text { 2. Often, the challenge students had to move through was } \\
\text { connected to race, gender, religion, or age limitations. Often, } \\
\text { what allowed the students' challenge to evolve into an } \\
\text { engaging experience was some kind of supportive } \\
\text { connection with other people. (Course One) }\end{array}$ \\
$\begin{array}{l}\text { 3. One highly reflective "outlier" student struggled to connect } \\
\text { to the trust and hope that support service. Her experience } \\
\text { informed the study revision. (Course Two) }\end{array}$ \\
\hline $\begin{array}{l}\text { Area for Development 2: } \\
\text { Explore modes to deepen } \\
\text { online engagement. }\end{array}$ & $\begin{array}{l}\text { 1. Five out of 16 students showed little evidence of } \\
\text { meaningfully engaging with the reflection goals; they } \\
\text { responded to the prompts but deflected the deeper inquiry. } \\
\text { (Course Two) }\end{array}$ \\
\hline
\end{tabular}

Area for Development 1: More explicitly critical material could support student reengagement

In both courses, students encountered themes about power dynamics in society. In Course One, this occurred through the narrative assignment; a significant number of students' experiences of disengagement connected to race and gender. One example was Carla's statement that "I would face a lot of self-doubt going forward because I feel that I am faulty and therefore I have no business taking part in this...Inequality thinking is unfortunately inside me...There are norms I don't think I believe in, but I am always skewed." Though both courses contain readings about power and privilege, going forward, it seems the curriculum should include readings that specifically address how individuals have been both impacted by, and moved through, race and gender limitations 
in the context of civic participation. Readings addressing critiques of market-based assumptions could also be helpful. Karen wrote she had learned "to deconstruct the standards I set for myself," but I think this component could have gone deeper. It is possible that class discussion of these readings would enhance the learning around the Critical Insight competency and help students contextualize their experiences. It could enhance students' ability to generate civic visions by helping them identify how they may have internalized ideas about inequities as based in unequal capacity rather than biased policy.

In Course Two, the case of Amelia suggested a similar adjustment in the curriculum. Amelia felt overwhelmed by a pattern of federal policy that did not match her values of equity and environmental stewardship. From her posts and essays, it did not seem that Amelia was connected to critical perspectives in the media or academe that could have helped her identify the values underlying the policies. To some extent, the text's coverage of New Public Management (application of market principles to the public sector) did serve this purpose. But the curriculum could benefit from current texts to help students identify values and mindsets underneath current policy trends.

Area for Development 2: Explore modes to deepen online engagement.

While this study does not seek to generalize about the differences between online and in-person college courses, one finding does suggest the need to engage with this question. While only one person in the in-person course seemed to deflect the selfreflection components, five people in the online course did. Furthermore, in the in-person class, the individual who struggled also struggled with academic writing and the rest of 
the course content. In the online course, the five students were generally strong writers and seemed able to digest the theories; their own challenge was the reflection. This indicates that the format of the online course may have impacted these students; they did not have the opportunity to build a learning community in person. While for some students, the online environment is more comfortable, research has suggested that hybrid rather than fully online courses are typically more beneficial (Gould, 2003). Without this option, in future it would be important to add more researched strategies for online community building.

In reflecting on Course Two and its online format, I found that the aims of inspiring students and encouraging them to understand for themselves what they enjoyed about service, were particularly hard to teach. I wrote in a memo on the second narrative assignment:

This assignment seems to be engaging students' minds in service of their hearts. They are learning to see in their own feelings and in the responses of others, in their motivations and thoughts, how their service has gone sideways, and could go sideways again. They become better equipped to re-center on service. That said, I think if we had met in person, even three times, I could have helped them come to enjoy this re-centering, find pleasure in service, and find more enthusiasm. One insight is that this pleasure is important, and it would be really valuable to have more readings about the pleasure of service.

Again, the importance I place upon the development of intrinsic motivation shows in this passage. The online format seemed to stymie the conveyance of this relatively intangible 
capacity. More development is needed in order to deeply teach intrinsic motivation through the HCEE process, but particularly through online courses.

\section{Two Key Limitations: Understanding the Curricular Context for HCEE}

Two aspects of the curriculum are particularly important to investigate going forward in order to better understand the learning context in which HCEE can best unfold. One limitation of this study is it was beyond its scope to assess the impacts of these two curricular components. The first of these was community-based learning, a strategy used in all Civic Leadership Minor courses and in many departments across the University. The second was the effort to build relationships and community among students. Both of these curricular components could have contributed to the effectiveness of the tool implementation, and this potential impact is key to explore.

First, the community-based learning (CBL) components of the courses could have impacted students' learning. It could have enhanced their ability to utilize the reengagement tool by increasing their empathy, revealing civic visions, or motivating their service. Additionally, the CBL experiences could have supported students' learning of the HCEE competencies and capacities by exposing them to innovative approaches to community problems, new visions held by community organizations, or new modes of relating with others in civic contexts. It is also possible that the CBL components detracted from students' HCEE learning and ability to wield the re-engagement tool. However, CBL assignments are generally considered to be impactful and to build civic republican attitudes and behaviors (Ehrlich, 2008; Flores \& Rogers, 2019; Jacoby, 1996, 2009; Saltmarsh, 2011; Saltmarsh, Hartley \& Clayton, 2009; Welch \& Koth, 2009). CBL 
assignments are required for both courses at the program level, and the structure of these assignments is largely set by programmatic goals. Below I briefly discuss how the CBL projects for the two courses may have impacted student learning. We can view this as a consideration of one limitation of the study — the full assessment of the impacts of CBL components was beyond the scope of the study, but would need to be explicated as HCEE evolves.

The CBL component for Course One (See Appendix A "Course Requirements") required students to attend and reflect upon community events that "align with your civic interests and challenge you in some way." The aim was "to step into some new and intriguing aspect of civic engagement" and observe how event leaders seemed to define community engagement and social change. Furthermore, students were prompted to observe themselves: "How do you notice yourself reacting to different components of the event? What inspires you or disappoints you? What concerns or alternative possibilities does the event bring up for you?" Students processed this learning through small group discussions throughout the term, and through creating a final "context map" in which they visually connected their CBL learning to course readings and concepts.

This assignment was intended to draw on the power of experiential learning. It asked students explicitly (which I explained in class) to challenge themselves by stepping out of their "comfort zone." This was emphasized in order to help teach students that they have a choice to engage according to their values, even when the uncertainties of civic life often make it uncomfortable to do so. The assignment was also intended to show them how civic leaders can powerfully shape attitudes and relationships based on how 
they design civic events. Finally, the CBL component was meant to show students the potential pleasures of civic community, or at least inspire them to seek out more suitable community events going forward. In doing this assignment, students were exposed to wider civic visions (East), relationships with others (South), learning through experience (West), and to possible ways of using gifts in civic life (North). Group discussion prompts encouraged students to expand this learning further through hearing about others' experiences. Based upon our current understanding of CBL pedagogy, it is likely this work helped students develop the HCEE competencies and capacities. Further study of the impacts of CBL assignments could include pre- and post-assessments of civic attitudes, and a writing assignment designed to reveal student learning specifically from the CBL component.

The CBL component in Course Two related to the specific focus on public service (See Appendix F “Course Requirements”). It required students to select a public sector or non-profit organization, arrange an interview with a leader, and volunteer there to further their learning and contribute to the organization's mission. Students were guided to focus on "agencies engaged in partnership building to solve a public problem and the arrangements for engaging citizens," and asked to write a paper about their learning in the context of course materials. The intentions of this assignment were to provide concrete context in which students could: apply the theories from class, consider their own future leadership, and find an expanded understanding of how their civic concerns could be addressed by public organizations. It is possible that in doing the CBL assignments, students in Course Two were supported in both using the tool and 
developing the competencies/capacities. For example, they could have observed dynamics of fixing or serving during their experience, and found perspective and awareness about themselves based upon this, which would support the tool. They also might have been exposed to new visions or critical perspectives adopted by organizations (East). They might have had opportunity to consider their own gifts and interests as they connected with others in their experience (South). They might have built empathy as their experiences revealed more about the causes and challenges underlying civic problems (West). Finally, they might have observed public leaders demonstrating trust in larger processes or commitments to a worldview of interconnectedness that could have expanded their capacity for this (North). As with Course One, the role of the CBL learning lie outside of our primary inquiry into the impacts of the re-engagement tool. Not understanding this role is indeed a limitation here, and an important direction for further investigation into how students can best learn the HCEE competencies and capacities.

In addition to community based learning, it would be necessary going forward to assess the role of classroom culture and relationships on HCEE learning. I referred briefly in Chapter Four to some measures in Course One to build community, which included opening circles, community announcements, group learning tasks, and focusing on the assets of fellow students. However, a full investigation of how classroom culture shaped learning was beyond the scope here. Most scholars agree that learning environments that foster belonging, inclusion and growth are conducive to civic and academic learning in higher education (Bean \& Eaton, 2001; Stebleton, et al., 2014; Tinto, 2020). In particular, 
these factors are important to HCEE because of the tool's emphasis on empathy as a driver of re-engagement and enhanced capacity. Empathy can be modeled by instructors as they create class culture, and it follows that these measures could be quite important to students' ability to wield the tool effectively. We saw from the Course One reflections that students reported finding the class community to be inclusive and engaging, and an enjoyable space in which they could take intellectual risks. The study design does not, however, allow us to draw conclusions about how important this sense of community was to achieving learning outcomes. This limitation could be addressed in the future through looking at how different instructors' varying emphases on class community affected outcomes. It could also be studied by asking students to reflect directly on the impact of classroom community on their course learning.

\section{Additional Learning from Implementation}

Implementing the study led to several further learnings about the student population and designing responsive curricula. These learnings are discussed below; they include realizations about the significance of: teaching students in their first term at PSU, incoming students' views of engagement and service, holding realistic expectations about students' capacity to work with civic vision, and sense of place.

New to PSU

One pattern that I noted in Course One was that the majority of students were in their first term at a new institution. Though this meant higher anxiety levels, it also signaled to me that students might be more open to the community-building components of the course. I adjusted to this finding by including brief insets into the course that 
would welcome and orient students to PSU. For example, during Week Two, I posed a check-in question to introduce the theme of civic spaces which doubled as orientation-I asked each person to share their favorite place on campus and why they felt positively about it. The curricular aim was to begin to name the themes of what factors make spaces conducive to civic interaction. The affective aim was to create a class list of spaces in which students might feel welcome and part of the PSU community. In eliciting this list, I was signaling to students that I did not assume they felt safe everywhere, that it was acceptable to seek out community and support, and, most importantly, that it would be part of their role as civic leaders to create welcoming spaces for others.

Incoming students' understandings of civic engagement

The finding from Course One that students' initial understandings of civic engagement were largely apolitical was significant. It is important to acknowledge the asset brought by this group in its value of representativeness and responsiveness. However, in order to tailor learning experiences for this group, it is also important to articulate what is missing from their understanding. Their non-strategic, non-specific conception of civic engagement, though not the students' fault, is problematic. This view seems to connect to the wider societal patterns of overwhelm, shame and distraction. These states are fed partly by lack of clarity about policy levers and ignorance of history's lessons about the mechanisms of social change. Anxiety is exacerbated by high levels of care with low levels of agency, power, and resources. This finding mirrored that of Sears (2014), that students' knowledge of the civic potential of community action and 
civil society, as well as of political advocacy, were far weaker than knowledge based on personal volunteer experience and frequently-covered topics of structures of government.

An additional observation that emerged from the Course One pre-assessment was that students' conception of civic engagement was largely extrinsic. The value of this is, again, their value of responsiveness. However, intrinsic motivation is also important in sustaining civic engagement over time. Citizens need to balance their receptivity with steadfastness in their commitment to long term goals (Loeb, 2014).

The Course Two pre-assessment mirrored that of Course One. It revealed that students were, nearly universally, arriving with a strong commitment to public service. There was room for them to grow, however, in their understanding of individual service in the context of institutional values and policies, as well as in their development of an intrinsic orientation to service that could help them weather short-term failure. The first of these areas was an explicit goal of the course when I adopted it. The second, however, was a more holistic competency that I was seeking to add to the course content. The narrative sequence did seem to support growth in intrinsic commitment by orienting students to the internal work of service through reflecting on their needs. However, more reading material pointing out the value of intrinsic motivation would be beneficial in future. This question of "how to enjoy and be sustained by service even when facing short-term failure" would have likely come up in class discussions, were the course offered in person. For the online offering, readings and prompts could spur exploration of this topic. 
In memoing about both courses, the question of intrinsic and sustained motivation again emerged as important to me:

I am not diminishing what they have, but I want more for these students. I want them to be focused on outcomes and able to move forward when they don't see them. I want them to value their own learning as they engage. And I want them to learn how to sit with the vast unmet needs in the world without collapsing.

This topic is core to the aims of HCEE, and there is much room for evolution in teaching this through HCEE courses.

\section{Holding more realistic expectations around vision}

In both courses, the vision component of the tool was achieved more modestly than I was expecting. The tool asked students to state civic visions and "invoke" these as they reoriented toward a new level of capacity. However, though visioning is seen as valuable in civic education, it was unreasonable to expect students of a traditional college age to generate specific visions (Hicks, 2001). I realized that a generalized re-engagement — with a sense of agency, capacity, and possibility—-toward democratic outcomes, could be a developmentally appropriate and sufficient aim for the assignment.

Relatedly, going forward, the final essay for Course One should be scaled down. With their final CBL project—a poster presentation assignment not analyzed for the study, but taken very seriously by students—and their exams for other classes, students did not appear to have the bandwidth for an essay asking them to explore all four stages of the Model. Scaling down the essay could make more room for in-depth reading discussions. 
Sense of place

Finally, upon reflecting on the courses, I felt that more emphasis on "sense of place"-connection to the history and culture as well as experiential connection-would be beneficial going forward. Course One included a field trip to the waterfront park to learn about its civic history and reflect on the impact of civic engagement upon that space. However, Indigenous Knowledge emphasizes connection to place as key to education, and additional field trips and speakers would benefit these curricula.

\section{Development of the Model of Holistic Civic Engagement Education}

\section{The Model}

Allowing this Model to have significance and benefit requires us to be clear on the distinction between the Model and the Tool. The Model (Figure 5.1) is the application of Bell's (2014) Wheel to civic engagement learning, and sits around her Wheel. It contains, at each stage, one capacity (the short phrase) and two competencies (two bolded words). The Model is intended to serve as a map for design of holistic civic engagement courses. The capacities and the competencies are intended to be applied by instructors to a variety of courses. This could include Humanities or Social Science courses that have a civic engagement component. Table 5.3 summarizes examples of two college courses and how the Model could be utilized. The re-engagement tool, on the other hand, is a specific application of the Model. It was developed to help teach re-engagement in the context of 300-level courses on Civic Engagement and Public Service. It was also developed in the context of my own background knowledge and goals. Below I discuss the further applicability of the Tool. 
Figure 5.1: Model of Holistic Civic Engagement Education around Bell's Wheel

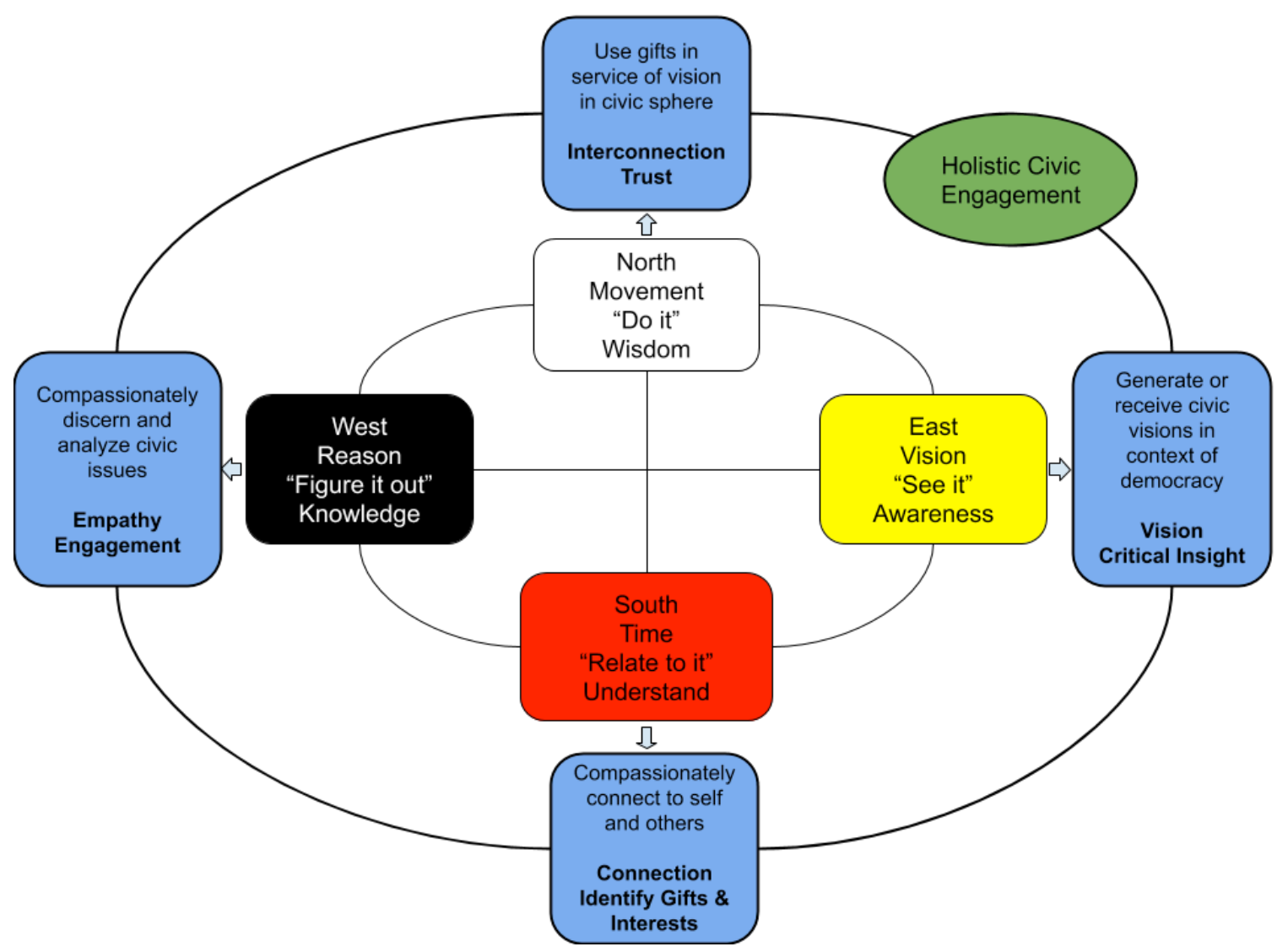


Table 5.3: Example Applications of the Model to Humanities/Social Science Courses

\begin{tabular}{|c|c|c|}
\hline Course & Key Assignment & Capacities and Competencies \\
\hline \begin{tabular}{|l}
$400-$ level \\
Oregon History
\end{tabular} & $\begin{array}{l}\text { Original research } \\
\text { project using oral } \\
\text { history to analyze } \\
\text { the framing of a } \\
\text { recent policy }\end{array}$ & $\begin{array}{l}\text { 1. East: Students frame the oral histories in terms of } \\
\text { research subjects' conception of democratic policy } \\
\text { making. } \\
\text { 2. South: Students conduct research. They write research } \\
\text { memos about how the policy area has impacted them. } \\
\text { Students identify any personal disengagement related to } \\
\text { the policy area. } \\
\text { 3. West: Students analyze the primary data to allow others } \\
\text { to engage with their historical narrative. Students respond } \\
\text { to their own disengagement with new perspective gained } \\
\text { from their research process. } \\
\text { 4. North: Students determine an appropriate context in } \\
\text { which to share their work with the public, including their } \\
\text { commentary on the significance for policy process. } \\
\text { Students reflect on shifts in their policy commitments and } \\
\text { the application of their gifts. }\end{array}$ \\
\hline $\begin{array}{l}\text { Capstone on } \\
\text { sustainable } \\
\text { international } \\
\text { development }\end{array}$ & $\begin{array}{l}\text { Local food } \\
\text { system analysis } \\
\text { to be shared with } \\
\text { NGO partner }\end{array}$ & $\begin{array}{l}\text { 1. South: Students identify the gifts and assets of the } \\
\text { community in relation to food production. They do so } \\
\text { after discussion and learning about creating connection } \\
\text { with local families and reflecting on asset-orientation. } \\
\text { They compassionately reflect on their biases and the } \\
\text { source of those beliefs. } \\
\text { 2. West: Students stay with a family and keep a journal of } \\
\text { cross-cultural learning as they follow engagement } \\
\text { prompts. Students track observations that inform deeper } \\
\text { understanding of food system. They address biases that } \\
\text { come up with empathetic analysis. } \\
\text { 3. North: Students build on previous teams' work to map } \\
\text { the food system according to their observations. They } \\
\text { frame their work in context of a larger process of } \\
\text { strengthening local food system. } \\
\text { 4. East: Students write a paper analyzing impact of large- } \\
\text { scale farming on the community. They articulate a } \\
\text { personal vision for a local food system. }\end{array}$ \\
\hline
\end{tabular}

In the case of these two hypothetical courses designed with the Model, the key

functional difference is the intention to teach, in addition to increased awareness,

knowledge and empathy, an increased freedom and capacity to respond. This is done

through asking students to gently examine their own beliefs, actively challenge those 
beliefs with empathetic analysis, and then consider how this frees them to receive a new vision of what is possible, or use their gift in new ways.

The Tool

Figure 5.2 shows, once again, the re-engagement tool. Additionally, Table 5.4 shows a simplified means for understanding the Tool. While the Model is intended to be applied over longer time frames such as classes, the Tool can be applied to shorter timeframes such as an event or a workshop. The Tool has four steps, though the fourth is the implicit step of contributing to civic life with increased capacity. The first step is the reflection upon disengagement. This needs to be done with gentleness; people should reflect and choose a specific instance, but not go deeper than they can handle. The second step is to apply empathetic analysis to that instance. Third, they negotiate a new relationship to that experience so they can move forward toward visions and values in a new way.

\section{Table 5.4: Simplified Re-engagement Tool}

\begin{tabular}{|l|}
\hline \multicolumn{1}{|c|}{ Steps of the Re-engagement Tool } \\
\hline 1. Assuming innate engagement and care, explore exceptions to this-places of disengagement \\
or superficial engagement. Identify and name exceptions with compassion. \\
2. Interact with empathy. Apply empathetic analysis to the above exceptions. \\
3. Focus on a vision or value. Identify what is needed to re-engage in service of that vision. \\
\hline
\end{tabular}


Figure 5.2: Re-engagement Tool

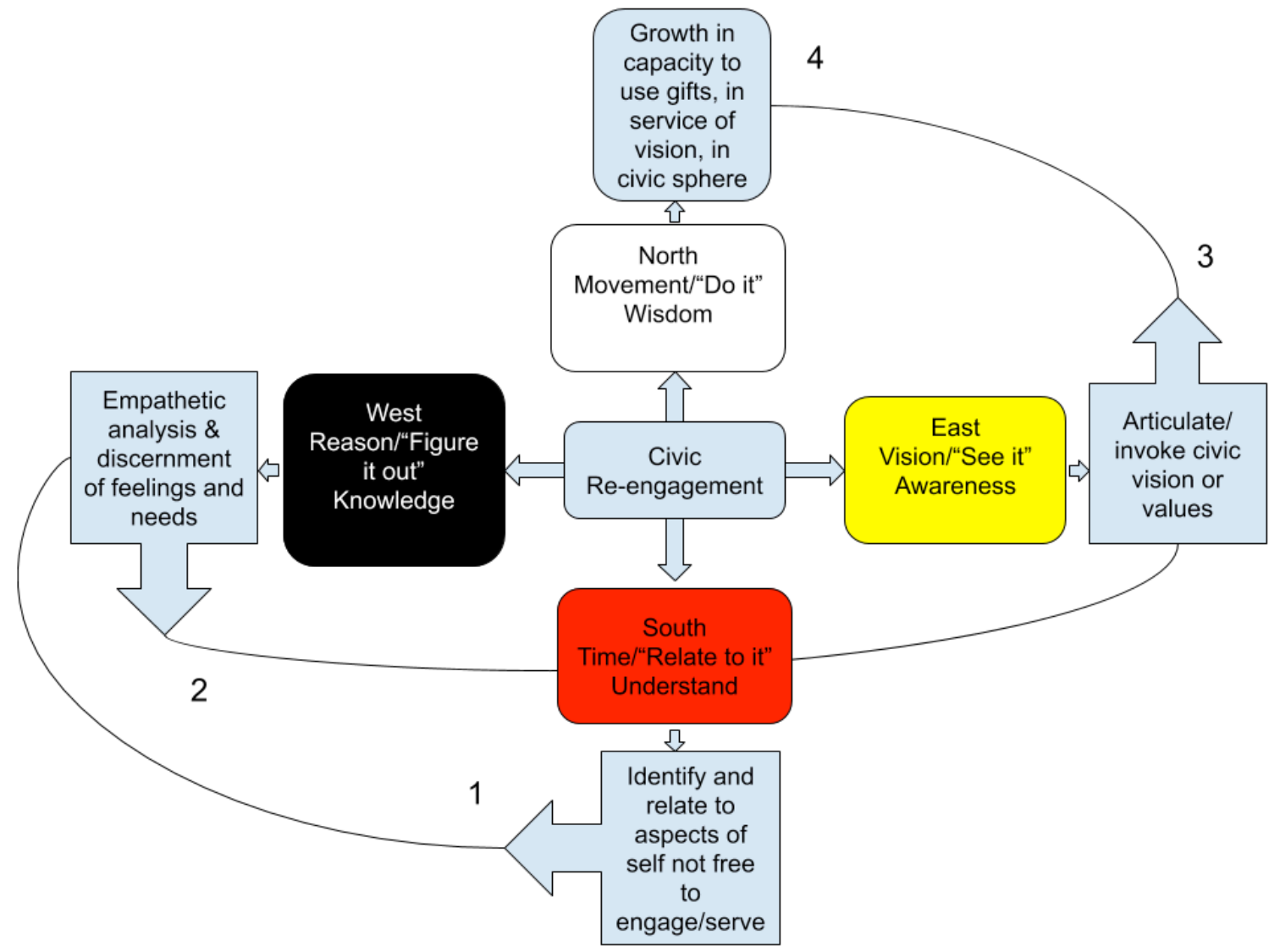

Based on the simplified understanding of the re-engagement tool, we can begin to see that the tool could be applicable to many courses that include "improving practice" among their goals. The re-engagement tool is called for when students are being asked to step into more skilled and mature work as practitioners. For instance, a photography course might include the aim to help students feel more artistic freedom and expand their creative resources. This course could implement the tool in an entirely visual way, asking students to portray an aspect of self not free to express (South), and then to express the feelings and needs of that self (West), along with visions of what could be possible with expression re-engaged (East). This kind of process could potentially help photography 
students reconcile and arrive in the North with an increased capacity for expression. A second example could include a leadership course with the aim of helping students grow in their practice. This course could guide students through re-engaging with their capacity for innovation, collaboration, or even their strategic analysis. While these examples do begin to take us away from direct treatment of civic engagement, it is important to consider that capacities such as freedom of expression, sense of empowerment, innovation and collaboration are political capacities. A democratic society might value these in their own right, and trust that individual capacity building — through addressing past disengagement — serves to enhance collective civic capacity.

\section{Broader Implications of HCEE}

Though used here to design curricula that support re-engagement, on a broader level, the Model is intended to guide a definition of civic behavior as wisdom, compassion, and care in action, and a natural expression of human investment in the whole based on an understanding of connection to the whole. Developing the capacity to act in this way requires us to see ourselves and our beliefs clearly, and to grapple with the aspects of ourselves that operate from fear or self-centeredness. Two significant broader implications emerge from this application of a holistic framework to civic engagement and civic education. The first is that we need to be prepared to discuss the role of healing in building collective civic capacity, and the extent to which we are comfortable with the framework of healing coming into educational and community spaces. The second is that applying a holistic framework to civic education raises the question of how holism also 
informs the process of public policy analysis, especially the most upstream phases of it, including concept definition and framing of policy problems.

The first broad implication of applying a holistic lens to civic engagement education is that it raises questions about the role of a healing framework in education and communities. A holistic perspective on civic engagement means that we acknowledge that emotional competencies like empathy and spiritual competencies like interconnection can impact cognitive capacities such as critical analysis. With a holistic framework in place, it follows that we then ask how competencies for empathy and interconnection come to grow and be embodied within individuals. These questions take us into the realms of transformation and healing. To grow in capacity can indicate that we must change our deepest beliefs about our place in the world and our own agency. We are asked - if we accept what transformative education theory offers - to be vulnerable enough to allow our world views to be disrupted, and to potentially allow ourselves to have experiences of, say, interconnection, that interrupt common mental models based in, say, individualism and separation. Holistic framing of civic engagement sets us on this path that leads into vulnerability, transformation, and healing.

Yet contemporary culture typically considers healing to be an individual responsibility. A neoliberal conception of the citizen, in particular, would see disengagement as a personal shortcoming to be addressed on a personal scale. Questioning this conception, and adopting the holistic frame, we must face the possibility that disengagement—often caused by institutional and cultural factors that are distinctly impersonal and inherently collective in nature - can only be ameliorated in society by 
allowing healing to be a public and shared concern. However, if we are willing to do this, we should then turn to the question of what it could look like in a diverse society. If we turn to the sources humans have developed for how to heal, we see a depth of perspectives. A question that then arises is "How can we utilize methods for healing in ways that do not appropriate, do not indoctrinate, and that lend themselves to the goal of systematically bringing compassion to individuals and institutions?"

The second broad implication of applying a holistic lens to civic engagement education is that doing so raises questions about how holism might inform policy framing and analysis. If we see civic engagement through the holistic frame, we begin to think of civic behavior as stemming from deeper and more subtle factors. If holistic civic engagement requires deeper work of "becoming" and "embodying" civic competencies and capacities, then our conception of what encourages civic behaviors shifts. It is not just the work of civic educators to consider how encourage this "becoming," it is-if we accept the New Public Service approach—also the work of public leaders. Thus we would see it as part of government's role to shape citizens and encourage the deepest forms of empowerment, which according to my model, would include such competencies as interconnection and vision.

Holistic thinking embedded into the upstream phases of policy analysis, i.e. into concept formation and problem framing, would potentially mean asking how public problems could be understood as problems of holistic competency. It could potentially mean framing problems as, for instance, spaces or ways in which interconnectedness or vision were not able to be lived and expressed by the polity. This kind of framing could 
lead to policymaking along lines we may not have explored. This approach of seeing policy as "practices and procedures that encourage holistic civic competencies among the citizenry" could be a fruitful approach as it could reveal ways of widening the notion of "public good" to include wellbeing, wholeness and full freedom to engage.

Furthermore, if we allow the cultivation of competencies such as interconnection to become public concerns, then we would also need to ask how humans' interconnection with nature could be encouraged through policy and democratic process. Significantly, Armstrong (2008) has written about how Indigenous Knowledge provides processes and practices for doing this. Armstrong's work indicates that modes of governance and decision making can facilitate interconnection between humans, and between humans and nature. Learning from these modes, and considering how to adopt them in ways that are not appropriative, would be a highly fruitful area for further development and study in the fields of contemporary governance and Public Administration. The two broader implications discussed here are part of what makes this study distinct from other important work in the field. By adopting the holistic frame and the aim of re-engagement, we can open doors to deeper transformation of disengagement, and to understandings of governance that embody deeper notions of community wellbeing.

\section{Areas for Further Study}

Several areas for further study are important, especially because the Model and Tool are in the early stages of development. The results here indicated that there likely was an increase in capacity for engagement for many students. However, further research should continue not only to assess apparent capacity, but begin to study longer-term 
evidence of capacity growth. Four areas should be explored as part of continuing to assess and develop HCEE. First, more study is needed of different applications of the Model and Tool in educational settings. Second, research should involve partnerships with Indigenous scholars. Third, implications for program-wide planning should be considered. Finally, tools for gathering quantitative data to assess impact should be created.

The first area for further research would be to apply the Model to more classes and assess the results. Part of this stage would involve developing training and sharing the Model and design strategy with select interested peers. All HCEE courses, taught by different instructors, could then be studied to gain a significant new level of awareness about the use of the Model. At this stage it would be important to note that training colleagues would take the form of collaborative co-design. It would be key to work closely with colleagues so that classes could best support students while we clarified the parameters and requirements of the HCEE teaching approach.

A second area, which could coincide with the first, would be to explore ways to support further application of Indigenous models of human development to civic education. As Madjidi \& Restoule (2008) note, the four stages of the Medicine Wheel are often connected not only to the cardinal directions, but to elements, seasons, or stages of life. More in-depth knowledge about the directions and about human development could more deeply inform how civic engagement could be learned. This work would need to emerge from partnership with Indigenous scholars, shared vision, and with respect for Indigenous knowledge as a priority. 
A third area for further development would be, if collective interest developed, to apply the Model to academic program design. Certain courses within a major or minor program might emphasize different stages and different competencies. Particularly important in this endeavor would be curriculum design and evaluation that paired application of the tool with substantive community based learning. The tool is designed to increase capacity for engagement; thus experiential engagement learning should combine with opportunities to practice the tool. Furthermore, as students participated in community activities, they would have the opportunity to observe any instances of disengagement. These experiences could be addressed through the tool, and new goals set for future engagement. Research at this stage would assess students' capacity to move through the cycle of reflection, re-engagement, and renewed action.

A final area for future study would be to develop a survey instrument to measure holistic civic engagement capacity and holistic civic action, on the part of graduates. Over time, it would be important to gather data that would allow us to (1) assess the degree of HCEE knowledge gained in particular courses and programs, as well as to (2) determine the degree to which HCEE learning correlated to democratic civic actions. Current tools exist to measure both actual and potential or latent engagements (Sears, 2014). It would be important to consider how existing tools could be used to assess the impacts of traditionally-conceptualized civic engagement actions versus the impacts of civic actions that the holistic lens would identify and prioritize. 


\section{Personal Future Contributions}

This study led me to realize that what I am specifically interested in is not only working in the realms of inspiration, vision and strategy, but in working with the past in service of the future. I think that the past holds rich information which we cannot overlook as we seek to move forward. While I think many civic engagement themed courses are very powerful in leading students toward the future-specifically, helping them adopt democratic values and commit to civic life-I am interested in the ways students get stuck and cannot seem to live their values. I want to understand how to teach skills, which I've called here re-engagement skills, that allow people to see beneath the surface of their actions to the feelings and belief systems impacting them. I do not think this work should be seen solely as the responsibility of the individual; though there may be overlap with therapeutic goals, this work is political, collective, and needs to be available to everyone. My sense is that we are currently sitting in a gap; while it seems apparent to many Americans_- and to thinkers such as Adrianne Marie Brown, Parker Palmer, and Charles Eisenstein - that we are operating from fear, anger and grief in our political behavior (the left and right both have examples of this), academe does not seem to have a full response to this. I am not invested in holistic approaches because I think we need to subvert our minds and stop using them. I think we need to clear our minds and use them as tools for compassionate, democratic, analysis. To do this, we need to find ways of going, together, into all of the dimensions that comprise our civic selves. 


\section{References}

Absolon, K. (1994, March). Building health from the Medicine Wheel: Aboriginal program development. Paper presented at the meeting of the Native Physician's Association, Winnipeg, Manitoba.

Allen, W. R., \& Epps, E. G. (1991). College in Black and White: African American students in predominantly White and in historically Black public universities. SUNY Press.

Anzaldúa, G. (1987). Borderlands: la frontera. Aunt Lute.

Argyris, C. \& Schön, D. (1991). Participatory action research and action science compared: A commentary. In W.F. Whyte (Ed.), Participatory action research (pp. 85-96). Sage.

Argyris, C., \& Schön, D.A. (1974). Theory in practice: Increasing professional effectiveness. Jossey-Bass.

Armon, J., \& Armon, C. (2015). Cultivating intimacy with the natural world: College students' care, connection, and regeneration in an agriculture-focused humanities course. Journal of Sustainability Education, 9(2).

Armstrong, J. (1996). Sharing one skin. In J. Mander \& E. Goldsmith (Eds.), The case against the global economy and a turn toward the local (pp. 460-470). Sierra Club Books.

Armstrong, J. (2008). An Okanagan worldview of society. In M. K. Nelson (Ed.), Original instructions: Indigenous teachings for a sustainable future (pp. 66-74). Bear \& Company.

Association of American Colleges and Universities. (n.d.). Civic learning: Leading organizations. https://www.aacu.org/resources/civic-learning/organizations.

Astin, A. W., Vogelgesang, L. J., Ikeda, E. K., \& Yee, J. A. (2000). How service learning affects students. Higher Education Research Institute, University of California.

Ausubel, D.P. (1968). Educational psychology: A cognitive view. Holt, Rinehart and Winston.

Banks, J. A. (2017). Failed citizenship and transformative civic education. Educational Researcher, 46(7), 366-377. 
Banyan, M. (2014). Civic capacity assessment framework. In D.F. Morgan, \& B.J. Cook (Eds.), New public governance: A Regime-centered perspective (pp. 101-110). ME Sharpe.

Barber, B. (2003). Strong democracy: Participatory politics for a new age. University of California Press.

Barbezat, D. \& M. Bush. (2013). Contemplative practices in higher education: Powerful methods to transform teaching and learning. Jossey-Bass.

Batacharya, S., \& Wong, Y. L. R. (Eds.). (2018). Sharing breath: Embodied learning and decolonization. Athabasca University Press.

Battiste, M. (2002). Indigenous knowledge and pedagogy in First Nations education: A literature review with recommendations. National Working Group on Education.

Battistoni, R. M. (2017). Civic engagement across the curriculum: A resource book for service-learning faculty in all disciplines. Campus Compact.

Baumgartner, L. M. (2001). An update on transformational learning. New Directions for Adult and Continuing Education, 89, 15-24.

Bean, J., \& Eaton, S. B. (2001). The psychology underlying successful retention practices. Journal of College Student Retention: Research, Theory \& Practice, 3(1), 73-89.

Bear, L. L. (2000). Jagged worldviews colliding. In Battiste, M. (Ed.), Reclaiming Indigenous voice and vision (pp. 77-85). University of British Columbia Press.

Beer, L. E., Rodriguez, K., Taylor, C., Martinez-Jones, N., Griffin, J., Smith, T. R., \& Anaya, R. (2015). Awareness, integration and interconnectedness: Contemplative practices of higher education professionals. Journal of Transformative Education, 13(2), 161-185.

Bell, N. (2014, June). Teaching by the medicine wheel: An Anishinaabe framework for Indigenous Education. Education Canada. https://www.edcan.ca/articles/teachingby-the-medicine-wheel/.

Bell, N. (n.d.) Nicole Bell's construction of the Anishinaabe Medicine Wheel teachings for Indigenous education. http://blog.cpco.on.ca/460-2/?print=pdf. 
Bellah, R. N., Tipton, S. M., Sullivan, W. M., Madsen, R., Swidler, A., \& Tipton, S. M. (2007). Habits of the heart: Individualism and commitment in American life. University of California Press.

Benhabib, S. (1992). Situating the self: Gender, community, and post-modernism in contemporary ethics. Routledge.

Berry, T. (1999). The great work: Our way into the future. Bell Tower.

Block, P. (2008). Community: The structure of belonging. Berrett-Koehler.

Bok, D. (2003). Universities in the marketplace. Princeton University Press.

Bopp, J., Bopp, M., Brown, L., \& Lane, P. (1984). The sacred tree. Four Worlds Development Project.

Boyte, H., Elkin, S., Levine, P., Mansbrige, J., Ostrom, E., Sotan, K., \& Smith, R. (2014). The new civic politics: Civic theory and practice for the future. The Good Society, 23(2), 206-211.

Brammer, L., Dumlao, R., Falk, A., Hollander, E., Knutson, E., Poehnert, J., \& Werner, V. (2012). Core competencies in civic engagement. Merrimack College Center for Engaged Democracy. https://scholarworks.merrimack.edu/cgi/viewcontent.cgi? $\underline{\operatorname{article}=1000 \& \text { context }=\text { ced_pubs. }}$.

Bringle, R. G., \& Hatcher, J. A. (1996). Implementing service learning in higher education. The Journal of Higher Education, 67(2), 221-239.

Brown, W. (2015). Undoing the demos: Neoliberalism's stealth revolution. MIT Press.

Bruner, J. (2003). Making stories: Law, literature, life. Harvard University Press.

Buissink-Smith, N., Mann, S., \& Shephard, K. (2011). How do we measure affective learning in higher education? Journal of Education for Sustainable Development, 5(1), 101-114.

Burns, H. (2016). Self-care as a way of being: Fostering inner work in a graduate sustainability leadership course. Ecopsychology, 8(4), 250-256.

Burns, H. (2015). Transformative sustainability pedagogy: Learning from ecological systems and indigenous wisdom. Journal of Transformative Education, 13(3), 259-276. 
Burns, H. L. and Briley, J. (2015). Going deep: Reflections on teaching deep ecology in Costa Rica. Transformative Dialogues: Teaching and Learning Journal, 8(2).

Burns, H. (2011). Teaching for transformation: (Re)Designing sustainability courses based on ecological principles. Journal of Sustainability Education, 2.

Cajete, G. (1994). Look to the mountain: An ecology of Indigenous education. Kivaki Press.

Calliou, S. (1995). Peacekeeping actions at home: A medicine wheel model for a peacekeeping pedagogy. In Battiste, M., \& Barman, J. (Eds.), First Nations education in Canada: The circle unfolds (pp. 47-72). University of British Columbia Press.

Capra, F. (2004). The hidden connections: A science for sustainable living. Anchor.

Carello, J., \& Butler, L. D. (2014). Potentially perilous pedagogies: Teaching trauma is not the same as trauma-informed teaching. Journal of Trauma \& Dissociation, $15(2), 153-168$.

Carr, W., \& Kemmis, S. (1986). Becoming critical: Education, knowledge, and action research. Falmer Press.

Castellano, M. B. (2000). Updating Aboriginal traditions of knowledge. In Hall, B. L., Rosenberg, D. G., \& Dei, G. J. S. (Eds.), Indigenous knowledges in global contexts: Multiple readings of our world (pp. 21-36). University of Toronto Press.

Charmaz, K. (2006). Constructing grounded theory: A practical guide through qualitative analysis. SAGE Publications.

Chesley, J., \& Wylson, A. (2016). Ambiguity: the emerging impact of mindfulness for change leaders. Journal of Change Management, 16(4), 317-336.

Chickering, A. W., Dalton, J. C., \& Stamm, L. (2015). Encouraging authenticity and spirituality in higher education. Jossey-Bass.

Christens, B. D., Winn, L. T., \& Duke, A. M. (2016). Empowerment and critical consciousness: A conceptual cross-fertilization. Adolescent Research Review, l(1), 15-27. 
Chubbuck, S. M., \& Zembylas, M. (2011). Toward a critical pedagogy for nonviolence in urban school contexts. Journal of Peace Education, 8(3), 259-275.

Clark, M. C., \& Rossiter, M. (2008). Narrative learning in adulthood. New Directions for Adult and Continuing Education, 119, 61-70.

Colby, A., Ehrlich, T., Beaumont, E., \& Stephens, J. (2003). Educating citizens. JosseyBass.

Cole, J. R. (2009). The great American university: Its rise to preeminence, its indispensable national role, why it must be protected. PublicAffairs.

Collins, P.H. (1998). Fighting words: Black women and the search for justice. University of Minnesota Press.

Couture, J. (1991). The role of native elders: Emergent issues. In Friesen, J. (Ed.), The cultural maze: Complex questions on native destiny in western Canada (pp. 201-217). Detselig Enterprises.

Cruea, S. M. (2005). Changing ideals of womanhood during the nineteenth-century woman movement. American Transcendental Quarterly, 19(3), 187-204.

Cunningham, K., \& McKinney, H. (2010). Towards the recognition and integration of action research and deliberative democracy. Journal of Public Deliberation, 6(1), $1-11$.

Cunningham, K., \& Leighninger, M. (2010). Research for democracy and democracy for research. New Directions for Higher Education, 152, 59-66.

Davidson, S. (2017). Trauma-informed practices for postsecondary education: A guide. Education Northwest. https://educationnorthwest.org/sites/default/files/ resources/trauma-informed-practices-postsecondary-508.pdf.

De Groot, I. (2018). Narrative learning for democratic citizenship identity: a theoretical framework. Educational Review, 70(4), 447-464.

Dirkx, J. (2001). The power of feelings: Emotion, imagination and the construction of meaning in adult learning. New Directions for Adult and Continuing Education, $89,63-72$. 
Dosemagen, D. M., \& Schwalbach, E. M. (2019). Legitimacy of and value in action research. In C.A. Mertler (Ed.), The Wiley handbook of action research in education (pp. 161-183). Wiley-Blackwell.

Dumont, J. in Stigelbauer, S. (1992). The Individual is the community; the community is the world; Native elders talk about what young people need to know. Paper presented at the meeting of the American Educational Research Association, San Francisco.

Dweck, C. (2016). Mindset: The new psychology of success. Ballantine Books.

Eaton, M., Davies, K., Gillespie, M., Harding, K., \& Parks, S. D. (2013). Living the questions: Contemplative and reflective practices in sustainability education. In P.F. Barlett, \& G.W. Chase (Eds.), Sustainability in higher education: Stories and strategies for transformation (pp. 261-277). MIT Press.

Edwards, M. A., \& Post, S. G. (Eds.). (2008). The love that does justice: Spiritual activism in dialogue with social science. Unlimited Love Press.

Efron, S. E., \& Ravid, R. (2019). Action research in education: A practical guide. Guilford Publications.

Ehrlich, T. (2009). Forward. In B. Jacoby (Ed.), Civic engagement in higher education: Concepts and practices (pp. v-vii). Jossey-Bass.

Elias, D. (1997). It's time to change our minds: An introduction to transformative learning. ReVision, 20(1), 2-7.

Englund, T., \& Solbrekke, T. D. (2014, March 5-7). Formation in higher education: Towards professional responsibility as deliberative praxis. Paper delivered to NERA 42nd Congress, Education for Sustainable Development, Lillehammer, Norway.

Ergas, O. (2016). Educating the wandering mind: Pedagogical mechanisms of mindfulness for a curricular blind spot. Journal of Transformative Education, 14(2), 98-119.

Ermine, W., (1995). Aboriginal epistemology. In Battiste, M., \& Barman, J. (Eds.), First Nations education in Canada: The circle unfolds (pp. 101-112). University of British Columbia Press. 
Falkenburger, E., Arena, O., \& Wolin, J. (2018, April). Trauma-informed community building and engagement. Urban Institute. https://www.urban.org/sites/default/ files/publication/98296/traumainformed community building and engagement 0.pdf.

Ferrer, J. N., Romero, M. T., \& Albareda, R. V. (2005). Integral transformative education: A participatory proposal. Journal of Transformative Education, 3(4), 306-330.

Finley, A. (2011). Civic learning and democratic engagements: A review of the literature on civic engagement in post-secondary education. Unpublished paper prepared for the U.S. Department of Education.

Fisher, D., Metcalfe, A. S., \& Field, C. (2016). The structural force exerted by marketization on higher education systems, research universities and academic researchers. In J.E. Cote \& A. Furlong (Eds.), Routledge handbook of the sociology of higher education (pp. 63-73). Routledge.

Fishkin, J. S. (1997). The voice of the people: Public opinion and democracy. Yale University Press.

Flanagan, C., \& Levine, P. (2010). Civic engagement and the transition to adulthood. The Future of Children, 20(1), 159-179.

Flores, W. \& Rogers, K. (Eds.). (2019). Democracy, civic engagement, and citizenship in higher education: Reclaiming our civic purpose. Lexington Books.

Forbes, S. H., \& Martin, R. A. (2004). An analysis of holistic schools' literature. Paper presented at the American Education Research Association Annual Conference, San Diego, CA.

Fung, A., \& Wright, E. O. (2003). Deepening democracy. Verso.

Freire, P. (1970). Pedagogy of the oppressed. Bloomsbury.

Friedman, W. (2007). Reframing 'framing.' Occasional Paper No. 1. Center for Advances in Public Engagement. http://www.starr-team.com/starr/RegionalWorkspaces/ RegionX/mitigationplanning/Shared\%20Documents/3-Effective PublicEngagement in Mitigation Planning/Reframing\%20Framing.pdf.

Galbraith, J. K. (1998). The affluent society. Houghton Mifflin Harcourt. 
Gardner, H. (2006). The development and education of the mind: The selected works of Howard Gardner. Routledge.

Gendlin, E. (1978). Focusing. Bantam Dell.

Gerald, J. E. (1963). Social responsibility of the press. University of Minnesota Press.

Ginwright, S. (2018). The future of healing: Shifting from trauma-informed care to healing centered engagement. Medium. https://medium.com/@ginwright/thefuture-of-healing-shifting-from-trauma-informed-care-to-healing-centeredengagement-634f557ce69c.

Ginwright, S. (2011). Hope, healing, and care. Liberal Education, 97(2), 34-39.

Giroux, H. A. (2002). Neoliberalism, corporate culture, and the promise of higher education: The university as a democratic public sphere. Harvard Educational Review, 72(4), 425-464.

Goldin, C., \& Katz, L. F. (1999). The shaping of higher education: The formative years in the United States, 1890 to 1940. Journal of Economic Perspectives, 13(1), 37-62.

Gould, T. (2003, June). Hybrid classes: Maximizing institutional resources and student learning. Paper presented at ASCUE Conference.

Greenwood, D. J., \& Levin, M. (2006). Introduction to action research: Social research for social change. Sage.

Gura, P. F. (2007). American transcendentalism: A history. Macmillan.

Gutmann, A., \& Thompson, D. (2009). Why deliberative democracy? Princeton University Press.

Hargreaves, A., \& Fink, D. (2012). Sustainable leadership (Vol. 6). John Wiley \& Sons.

Hart, A., Heaver, B., Brunnberg, E., Sandberg, A., Macpherson, H., Coombe, S., \& Kourkoutas, E. (2014). Resilience-building with disabled children and young people: A review and critique of the academic evidence base. International Journal of Child, Youth and Family Studies, 5(3), 394-422.

Hartley, M. (2011). Idealism and compromise and the civic engagement movement. In J. Saltmarsh \& M. Hartley (Eds.), "To serve a larger purpose": Engagement for 
democracy and the transformation of higher education (pp. 27-48). Temple University Press.

Hemenway, T. (2015). The permaculture city: Regenerative design for urban, suburban and town resilience. Chelsea Green.

Hicks, D. (2001). Re-examining the future: the challenge for citizenship education. Educational Review, 53(3), 229-240.

Holbein, J. (2017). Childhood skill development and adult political participation. American Political Science Review, 111(3), 572-583.

Holbein, J. B., \& Hillygus, D. S. (2020). Making young voters: Converting civic attitudes into civic action. Cambridge University Press.

Holland, B. (2011). Introduction to the engaged campus. In J. Saltmarsh, \& E. Zlotkowski (Eds.), Higher education and democracy: Essays on service-learning and civic engagement (pp. 281-284). Temple University Press.

hooks, b. (1994). Teaching to transgress: Education as the practice of freedom. Routledge.

Hope, E. C., \& Jagers, R. J. (2014). The role of sociopolitical attitudes and civic education in the civic engagement of Black youth. Journal of Research on Adolescence, 24(3), 460-470.

Hopkins, R. L. (1994). Narrative schooling: Experiential learning and the transformation of American education. Teachers College Press.

Houck, D. W., \& Dixon, D. E. (Eds.). (2006). Rhetoric, religion and the civil rights movement, 1954-1965 (Vol. 1). Baylor University Press.

Hylton, M. E. (2018). The role of civic literacy and social empathy on rates of civic engagement among university students. Journal of Higher Education Outreach and Engagement, 22(1), 87-106.

Immordino-Yang, M. H. (2016). Emotion, sociality, and the brain's default mode network: Insights for educational practice and policy. Policy Insights from the Behavioral and Brain Sciences, 3(2), 211-219. 
Immordino-Yang, M.H. \& Damasio, A.R. (2007). We feel, therefore we learn: The relevance of affective and social neuroscience to education. Mind, Brain and Education, 1(1), 3-10.

Jacobs, L. R., \& Skocpol, T. (Eds.). (2005). Inequality and American democracy: What we know and what we need to learn. Russell Sage Foundation.

Jacoby, B. (Ed.). (2009). Civic engagement in higher education: Concepts and practices. Jossey-Bass.

Jacoby, B. (1996). Service-learning in higher education: Concepts and practices. JosseyBass.

Jagers, R. J., Rivas-Drake, D., \& Williams, B. (2019). Transformative social and emotional learning (SEL): Toward SEL in service of educational equity and excellence. Educational Psychologist, 54(3), 162-184.

Karpiak, I. (2000). Writing our life: Adult learning and teaching through autobiography. Canadian Journal of University Continuing Education 26(1), 31-50.

Keating, A. (2016). Spiritual activism, visionary pragmatism, and threshold theorizing: An Anzaldúan meditation with black feminist thought. Departures in Critical Qualitative Research, 5(3), 101-107.

Keating, A. (2008). "I'm a citizen of the universe": Gloria Anzaldúa's spiritual activism as catalyst for social change. Feminist Studies, 34(1/2), 53-69.

Kecskes, K., Nishishiba, M., \& Morgan, D. (2013). Educating for new public governance: Civic engagement and the liberal arts. In D.F. Morgan, \& B.J. Cook (Eds.), New public governance: A regime-centered perspective (pp. 299-314). ME Sharpe.

Kemmis, S. (2010). What is to be done? The place of action research. Educational Action Research, 18(4), 417-427.

Kemmis, S. \& McTaggart, R. (Eds.). (1987). The action research planner. Deakin University Press.

Kirsch, G. E. (2009). From introspection to action: Connecting spirituality and civic engagement. College Composition and Communication, 60(4), 1-15. 
Klovenbach, P. (2000, October 6). The service of faith and the promotion of justice in Aamerican Jesuit higher education. Address at Santa Clara University. https:// www.scu.edu/ic/programs/ignatian-worldview/kolvenbach/.

Kolb, D. A. (1980). Experiential learning: Experience as the source of learning and development. Prentice Hall.

Krasny, M., Lundholm, C., \& Plummer, R. (2010). Resilience in social-ecological systems: The roles of learning and education. Environmental Education Research, 16(5-6), 463-474.

Lalas, J. W., Charest, B., Strikwerda, H., \& Ordaz, M. (2019). Nurturing hope, sense of belonging and engagement through equity. In K. Scorgie \& C. Forlin (Eds.), Promoting social inclusion: Co-creating environments that foster equity and belonging (pp. 41-52). Emerald Publishing.

Lazenby, S. (2014). Preparing the next generation for local government leadership. In D.F. Morgan, \& B.J. Cook (Eds.), New public governance: A regime-centered perspective (pp. 249-261). ME Sharpe.

Lertzman, R. (2015). Environmental melancholia: Psychoanalytic dimensions of engagement. Routledge.

Levinson, M. (2012). No citizen left behind. Harvard University Press.

Lewis, H. R. (2006). Excellence without a soul: How a great university forgot education. PublicAffairs.

Lin, J., Oxford, R. L., \& Brantmeier, E. J. (Eds.). (2013). ReEnvisioning higher education: Embodied pathways to wisdom and social transformation. Information Age Publishing.

Lovat, T., \& Clement, N. (2016). Service learning as holistic values pedagogy. Journal of Experiential Education, 39(2), 115-129.

Lune, H., \& Berg, B. L. (2016). Qualitative research methods for the social sciences. Pearson Higher Ed.

Macy, J. \& Brown, M. (2014). Coming back to life: The updated guide to the work that reconnects. New Society Publishers. 
Madjidi, K., \& Restoule, J. P. (2008). Comparative indigenous ways of knowing and learning. In K. Mundy, K. Bickmore, R. Hayhoe, M. Madden \& K. Madjidi (Eds.) Comparative and international education: Issues for teachers (pp. 77-106). Canadian Scholars Press.

Magis, K., M. Ingle,, \& N.H. Duc. EMERGE: Public leadership for sustainable development. In D.F. Morgan, \& B.J. Cook (Eds.), New public governance: $A$ regime-centered perspective. ME Sharpe.

Mahmoudi, S., Jafari, E., Nasrabadi, H. A., \& Liaghatdar, M. J. (2012). Holistic education: An approach for 21 century. International Education Studies, 5(2), 178-186.

Mansbridge, J. J. (1983). Beyond adversary democracy. University of Chicago Press.

Masemann, V. (1990). Ways of knowing: Implications for comparative education. Comparative Education Review, 34(4), 465-473.

McCutcheon, G., \& Jung, B. (1990). Alternative perspectives on action research. Theory Into Practice, 29(3), 144-151.

McKernan, J. (1988). The countenance of curriculum action research: Traditional, collaborative, and emancipatory-critical conceptions. Journal of Curriculum and Supervision, 3(3), 173-200.

Meadows, D. H. (1999). Leverage points: Places to intervene in a system. Sustainability Institute.

Menakem, R. (2017). My grandmother's hands: Racialized trauma and the pathway to mending our hearts and bodies. Central Recovery Press.

Mezirow, J. (1990). Fostering critical reflection in adulthood: A guide to transformative and emancipatory education. Jossey-Bass.

Mezirow, J. (1981). A critical theory of adult learning and education. Adult education quarterly 32, 3-24.

Miller, J. P., \& Nigh, K. (2017). Holistic education and embodied learning. Information Age Publishing.

Miller, R. (1990). Beyond reductionism: The emerging holistic paradigm in education. The Humanistic Psychologist, 18(3), 314-323. 
Miller, J. P., Karsten, S., Denton, D., Orr, D., \& Kates, I. C. (Eds.). (2005). Holistic learning and spirituality in education: Breaking new ground. SUNY Press.

Miller, J. P. (2007). The holistic curriculum. University of Toronto Press.

Mitchell, T. D. (2015). Identity and social action: The role of self-examination in systemic change. Diversity \& Democracy, 18(4), 15-17.

Moeke-Pickering, T., Hardy, S., Manitowabi, S., Mawhiney, E.F., Gibson-van Marrewijk, K., Tobias, N., \& Taitoko, M. (2006). Keeping our fire alive: Towards decolonizing research in the academic setting. World Indigenous Nations Higher Education Consortium Journal, 5.

Morgan, D. (2013). Educating leaders for new public governance: Public administration as a liberal art. In D.F. Morgan, \& B.J. Cook (Eds.), New public governance: $A$ regime-centered perspective (262-283). ME Sharpe.

Morgan, D. L. (2014). Integrating qualitative and quantitative methods: A pragmatic approach. Sage.

National Center for Education Statistics. (2019). Undergraduate enrollment. https:// nces.ed.gov/programs/coe/indicator_cha.asp.

Neff, K. (2011). Self-compassion. HarperCollins.

Niemi, R.G. (2012). What students know about civics and government. In D.E. Campbell, M. Levinson, \& F.M. Hess (Eds.), Making civics count: Citizenship education for a new generation (pp. 15-35). Harvard Educational Press.

O'Connell, B. (1999). Civil society: The underpinnings of American democracy. University Press of New England.

Orr, D. (2011). Hope is an imperative: The essential David Orr. Island Press.

O'Sullivan, E. (2002). The project and vision of transformative education: Integral transformative learning. In E. O’Sullivan, A. Morrell, M. O'Connor (Eds.), Expanding the boundaries of transformative learning (pp. 1-12). Palgrave.

Palmer, P. J. (1997). The heart of a teacher identity and integrity in teaching. Change: The Magazine of Higher Learning, 29(6), 14-21. 
Palmer, P.J., \& A. Zajonc. (2010). The heart of higher education: A call to renewal. Jossey-Bass.

Palmer, P. J. (2011). Healing the heart of democracy: The courage to create a politics worthy of the human spirit. Jossey-Bass.

Peterson, A. (2011). Civic republicanism and civic education. Palgrave MacMillan.

Portland State University. (n.d.). Undergraduate civic leadership minor. https:// www.pdx.edu/hatfieldschool/undergraduate-civic-leadership-minor-0).

Portland State University. (n.d.). Course catalog. https://app.banner.pdx.edu/ StudentRegistrationSsb/ssb/registration.

Prilleltensky, I. (2008). The role of power in wellness, oppression and liberation: The promise of psychopolitical validity. Journal of Community Psychology, 36(2), $116-136$.

Prilleltensky, I. \& Fox, D. R. (2007). Psychopolitical literacy for wellness and justice. Journal of Community Psychology, 35(6), 793-805.

Prilleltensky, I., \& Prilleltensky, O. (2006). Promoting well-being: Linking personal, organizational, and community change. John Wiley.

Putnam, R. D., Leonardi, R., \& Nanetti, R. Y. (1994). Making democracy work: Civic traditions in modern Italy. Princeton University Press.

Putnam, R. D. (2001). Bowling alone: The collapse and revival of American community. Simon \& Schuster.

Putnam, R. D., \& Feldstein, L. M. (2004). Better together: Restoring the American community. Simon \& Schuster.

Pyles, L., \& Adam, G. (Eds.). (2016). Holistic engagement: Transformative social work education in the 21st century. Oxford University Press.

Ragoonaden, K. (2015). Mindful teaching and learning: Developing a pedagogy of wellbeing. Lexington Books.

Rawls, J. (1971). A theory of justice. Harvard University Press.

Reich, R. (2015). Saving capitalism. Vintage Books. 
Reiff, J. D., \& Keene, A. S. (2012). Best practices for promoting student civic engagement: Lessons from the citizen scholars program at University of Massachusetts Amherst. Journal of Higher Education Outreach and Engagement, 16(4), 105-128.

Remen, R. N. (1999, September). Helping, fixing or serving? Shambhala Sun.

Rittel, H. W., \& Webber, M. M. (1973). Dilemmas in a general theory of planning. Policy sciences, 4(2), 155-169.

Rockefeller, S. C. (1994). Meditation, social change, and undergraduate education. The Center for Contemplative Mind in Society.

Rosenberg, M. B. (2002). Nonviolent communication: A language of compassion. Puddledancer press.

Rossiter, M. (2002). Narrative and stories in adult teaching and learning. ERIC Digest $241,1-8$.

Ryoo, J. J., Crawford, J., Moreno, D., \& McLaren, P. (2009). Critical spiritual pedagogy: Reclaiming humanity through a pedagogy of integrity, community, and love. Power and Education, 1(1), 132-146.

Saltmarsh, J. (2011). The civic promise of service-learning. In J. Saltmarsh, \& E. Zlotkowski (Eds.), Higher education and democracy: Essays on service-learning and civic engagement (pp. 28-34). Temple University Press.

Saltmarsh, J., Hartley, M., \& Clayton, P. (2009). Democratic engagement white paper. Universtiy of Pennsylvania Graduate School of Education. https:// repository.upenn.edu/cgi/viewcontent.cgi?article $=1252 \&$ context $=$ gse pubs.

Sanchez, R. E. C., \& So, M. L. (2015). UC Berkeley's undocumented student program: Holistic strategies for undocumented student equitable success across higher education. Harvard Educational Review, 85(3), 464-477.

Sandel, M. J. (1998). Democracy's discontent: America in search of a public philosophy. Harvard University Press.

Sanders, L. A., Ed. (2013). Contemplative studies in higher education: New directions for teaching and learning, No. 134. Jossey-Bass. 
Schoem, D. L., \& Hurtado, S. (Eds.). (2001). Intergroup dialogue: Deliberative democracy in school, college, community, and workplace. University of Michigan Press.

Sears, A. (2014). Measuring what matters: Citizenship domain. People for Education. https://peopleforeducation.ca/wp-content/uploads/2017/06/ MWM_CitizenshipPaper.pdf.

Senge, P. (1990). The fifth discipline: The art and science of the learning organization. Currency Doubleday.

Shaffer, T. J. (2014). Deliberation in and through higher education. International Journal of Public Participation, 10(1). https://www.publicdeliberation.net/cgi/ viewcontent.cgi?article=1324\&context=jpd.

Shapiro, S., Brown, K.W., \& Austin, J.A. (2011). Toward the integration of meditation into higher education: A review of research evidence. Teachers College Record, $113,493-528$.

Shephard, K. (2008). Higher education for sustainability: Seeking affective learning outcomes. International Journal of Sustainability in Higher Education, 9(1), 87-98.

Sheridan, M. J. (2012). Spiritual activism: Grounding ourselves in the spirit. Journal of Religion \& Spirituality in Social Work: Social Thought, 31(1-2), 193-208.

Stebleton, M. J., Soria, K. M., Huesman Jr, R. L., \& Torres, V. (2014). Recent immigrant students at research universities: The relationship between campus climate and sense of belonging. Journal of College Student Development, 55(2), 196-202.

Sterling, S. (2002). Sustainable education: Re-visioning learning and change. Green Books.

Sterling, S. (2004). Higher education, sustainability, and the role of systemic learning. In Corcoran, P.B. \& E.A.J. Wals (Eds.), Higher education and the challenge of sustainability (pp. 49-70). Kluwer Academic Publishers.

Sterling, S. R., Jones, P., \& Selby, D. (Eds.). (2010). Sustainability education: Perspectives and practice across higher education. Earthscan.

Stiglitz, J. E. (2012). The price of inequality: How today's divided society endangers our future. W.W. Norton. 
Stone, D. A. (1997). Policy paradox: The art of political decision making. W.W. Norton.

Stringer, E. T. (2008). Action research in education. Pearson Prentice Hall.

Teasdale, W. (1999). The mystic heart: Discovering a universal spirituality in the world's religions. New World Library.

Thomas, N., \& Levine, P. (2011). Deliberative democracy and higher education: Higher education's democratic mission. In J. Saltmarsh \& M. Hartley (Eds.), "To serve a larger purpose": Engagement for democracy and the transformation of higher education (pp. 154-176). Temple University Press.

Thomashow, M. (1995). Ecological identity. MIT Press.

Tinto, V. (2020). Learning better together. In A. Olds, A. Jones, \& J. Lisciandro (Eds.), Transitioning students in higher education: Philosophy, pedagogy and practice. Routledge.

Tocqueville, A. (1805-1859/2003). Democracy in America. Penguin Classics.

Toulouse, P. (2016). What matters in Indigenous education: Implementing a vision committed to holism, diversity and engagement. People for Education. https:// peopleforeducation.ca/wp-content/uploads/2017/07/MWM-What-Matters-inIndigenous-Education.pdf.

Turner, B. S. (Ed.). (1993). Citizenship and social theory. Sage.

University of Michigan Center for Sustainable Systems. (2019). U.S. cities factsheet. http://css.umich.edu/factsheets/us-cities-factsheet.

Uslaner, E. M., \& Brown, M. (2005). Inequality, trust, and civic engagement. American Politics Research, 33(6), 868-894.

Vaughan-Lee, V. (2013). Spiritual ecology. Golden Sufi Center

Vygotsky, L. (1978). Mind in society: The development of higher psychological processes. Harvard University Press.

Wals, A. E., \& Corcoran, P. B. (Eds.). (2012). Learning for sustainability in times of accelerating change. Wageningen Academic Publications. 
Watts, R. J., Diemer, M. A., \& Voight, A. M. (2011). Critical consciousness: Current status and future directions. New Directions for Child and Adolescent Development, 134, 43-57.

Watts, R. J., \& Flanagan, C. (2007). Pushing the envelope on youth civic engagement: A developmental and liberation psychology perspective. Journal of Community Psychology, 35(6), 779-792.

Watts, R. J., Griffith, D. M., \& Abdul-Adil, J. (1999). Sociopolitical development as an antidote for oppression - theory and action. American Journal of Community Psychology, 27(2), 255-271.

Wheatley, M. (2006). Leadership and the new science: Discovering order in a chaotic world. Berrett-Koehler.

Ziegler, D. (n.d.). Optimum learning environments for traumatized children: How abused children learn best in school. Jasper Mountain Center. http:// www.jaspermountain.org/optimum_learning_environment.pdf.

Zimmerman, M. A., \& Zahniser, J. H. (1991). Refinements of spherespecific measures of perceived control: Development of a sociopolitical control scale. Journal of Community Psychology, 19(2), 189-204.

Zlotkowski, E. (2011). Social crises and the faculty response. In J. Saltmarsh, \& E. Zlotkowski (Eds.), Higher education and democracy: Essays on service-learning and civic engagement (pp. 13-27). Temple University Press. 
APPENDIX A: Course One Syllabus

\section{Portland State University \\ College of Urban and Public Affairs \\ Mark O. Hatfield School of Government \\ PA 311U: Introduction to Civic Engagement \\ Fall Term 2018}

\section{Scheduled Class Meetings:}

Tuesday and Thursday 12:00pm-1:50pm

Karl Miller Center 350

\section{Instructor:}

Jane Carr

Email: jacarr@pdx.edu

Office Hours by appointment

Urban Center Building, 670-16

\section{Course Description:}

This course examines the concept of civic engagement by exploring how relationships are strengthened and communication is nurtured among members of society, and how this contributes to a civic identity that promotes socially conscious thought and action. The course will examine the values, skills and actions that contribute to a sense of civic identity through assigned readings, lectures, discussions, group activities, and selfreflection. A central goal of this course is to help students prepare for a lifetime of responsible citizenship and civic engagement. This course includes a community-based learning project.

\section{Required Textbook:}

- Loeb, P.R., (2014). The impossible will take a little while. New York: Basic Books.

\section{Student learning objectives for this course:}

- Explore multiple dimensions of civic engagement;

- Elevate understanding of the complexity of multiple dimensions of human nature and behavior and the link to engagement;

- Understand and practice key civic engagement skills, including: a) written and oral communication; b) listening, synthesis and analysis; c) project planning with community partners; d) group process facilitation; e) collaborative decision making; and f) strategies for pursuing a public policy issue.

- Engage in outreach to community group leaders and community-based research; 
- Frame an issue facing a community in terms of generating capacities for leadership;

- Engage in self-reflection and self-assessment as a means to articulate a personal philosophy of leadership for the common good.

\section{Civic Leadership Minor:}

PA $311 \mathrm{U}$ is one of the three required courses to complete an academic Minor in Civic Leadership, offered by the Division of Public Administration in the Hatfield School of Government. For more information about the Minor, see http:/www.pdx.edu/ hatfieldschool/undergraduate-program. We recommend you meet with Elizabeth Benner, Academic Advisor for the Minor in Civic Leadership, who can be reached at ebenner@pdx.edu. Students are also encouraged to discuss their course selection and plan of study with the instructor.

Civic leadership minor students will learn how to positively affect the common good. Students will substantively explore:

1. Leadership theory, context and practice

Describe, analyze and apply leadership theories and concepts to historical, current, societal and personal contexts. Apply the theories of leadership to multiple social issues in varied community and cultural contexts through community engaged learning and projects.

2. Social change mechanisms

Explain governance, social, and political mechanisms for facilitating social change.

3. Personal and collective ethics, responsibility and agency

Demonstrate an understanding of individual and collective ethics and responsibility to multiple communities, cultures and political constituencies. Think critically and self-reflectively about personal roles in social and political structures.

4. Key civic leadership skills

Practice key civic leadership skills, such as democratic decision-making, collaborating effectively in diverse contexts, communication, community-engaged research, building consensus, facilitation, social organizing, project management, etc.

5. Effective public action

Conceptualize, develop, implement, and evaluate opportunities for effective public action.

6. Core civic leadership concepts

Synthesize and integrate concepts, relevant theories and frameworks of leadership, collaboration, community engagement, culture, social capital and social justice in contemporary civil society. 


\section{Community Based Learning Component:}

CBL courses encourage students to apply theories and classroom learning to real world situations that impact communities. CBL courses acknowledge that insights and understandings about key course themes are located in multiple places, including in students' life experiences, the classroom, and the community. This course's CBL component asks students to engage in community work within an area of interest. This involves an investment not only in an empathetic understanding of one's world, but also in the complex process of identifying one's own values and goals.

In CBL courses, students formally represent the university, the instructor, the host community partners, and themselves both inside and outside the classroom. Professional behavior is expected at all times.

\section{Expectations for Written Assignments:}

- Care and attention: Students are expected to take care with assignments, including neatness, proofreading, and looking up uncertain words or grammar rules. If inattention interferes with reading of the work, assignments may be returned to students for revision prior to grading.

- Paper format: Final papers should be typed, double spaced, use 12-point font, 1inch margins, and written in APA format. Assignments may be submitted in person (or via email by previous arrangement only). For printing, recycled (previously printed on one side) paper is fine. Please paper clip (rather than staple) papers, and include your name as a header or footer on all pages. Thank you for following these guidelines - it greatly helps in my management of assignments. Students who need guidance on formatting and style guide should refer to The OWL at Purdue University. The link is http://owl.english.purdue.edu/ owl/resource $/ 560 / 01 /$.

- Deadlines: Deadlines, including those for online submissions, are firm. If you require an extension, please request this with at least one week's notice. Without prior permission, assignments will lose one partial letter grade (A to A-) for every day the assignment is overdue.

\section{Course Requirements}

\section{Class Participation, Reading, and Attendance (20\%)}

Students are expected to practice leadership and engagement during all class sessions. Please make every reasonable effort to be in class each week. Much of what we do in class cannot be made up through readings. In class we rely on one another to come prepared so that we can engage deeply in conversations about the material. Preparation involves not only completing the readings and written assignments, but critically considering the key points of various readings, making connections to real world 
examples and case studies, and coming to class with questions. Thoughtful completion of in-class assignments is also expected. This course values thoughtful contributions to the conversation, but equally values the importance of engaged listening. Helping to create a sense of community in class is an important aspect of participation. Careful note taking is highly recommended, even when the class format is discussion, not lecture. This will help you track your thinking over the course of the term, and write a successful final paper.

As a practice of engagement, please turn off cell phones during class time. Note taking with laptops is not recommended. Please see instructor for exceptions.

\section{Reading Group Participation and Facilitation (15\%)}

In Week Two, students will form groups in class and meet five times throughout the term (Weeks 3-7) to discuss readings. The aim is make meaning out of the readings together, and also to be accountable to each other for completing readings. Each session will be facilitated by a group member who selects that session in advance. When facilitating a discussion group, your goal is to encourage participation and engagement from all members, while delving into the content. You will submit your (brief) notes from the presentation, due on the day you present, and these should include an indication of how you plan to encourage participation from all your group members.

\section{Personal Engagement Narrative (45\%)}

In important aim of this class is to reflect on develop your own civic engagement. This does not mean you have to become some sort of super-engaged citizen; it means developing clarity about (1) what engages you, (2) what disengages you, (3) what obstacles you have encountered or expect to encounter as you engage, (4) how you see your role as participant in community decision making (despite those obstacles), and (5) what civic visions of the future most inspire you. This assignment has three components:

- Dis/Engagement Baseline Narrative. (10\%). Due in Week Three, Thursday, October 11. This is a 2-3 page narrative explanation of the engagement mapping exercise we do in class on September 27. See me as soon as possible if you miss class the 27 th.

- Contextualization of Dis/Engagement Narrative. (15\%). This is a 3-4 page narrative connecting class readings and concepts to your Narrative. Due in Week Seven, Tuesday, November 6.

- Final Narrative. (20\%). This 4-5 page narrative is a final revision and update of the above contextualization assignment. A rubric will be provided in class. Due in class on Tuesday, November 20 (Week Nine).

\section{Civic Engagement Participant Observation: Community Based Learning Component (20\%)}

Students will attend two community events that align with your civic interests and challenge you in some way. In attending the events, the aim is to step into some new and 
intriguing aspect of civic engagement. While there, you are an observer and participant in two ways. First, you are observing the events' approach to community engagement. Try to identify the values and approach to social change that underlie how the event is organized. Second, you are observing yourself: How do you notice yourself reacting to different components of the event? Why? What inspires you or disappoints you? What concerns or alternative possibilities does the event bring up for you?

- Part 1: List of Options (5\%). On Tuesday of Week Two (October 2) please turn in a list of 3-4 organizations and/or events that you are considering attending.

- Part 2: CBL Event \& Civic Engagement Context Maps (15\%). On the last day of class (November 29) will be due a synthesis of your CBL experience and course learning in the form of a concept map. Drawing on course readings and concepts, place your CBL events in the context of civic engagement as you have come to understand it. Maps can be created with technology or by hand - they need to demonstrate thoughtful connections you have made between readings, events, and ideas. The maps will be shared in presentations to a small group.

\section{Final Grades:}

Students will be graded on a percentage scale out of 100 points.

$$
\begin{array}{ll}
94-100 \%=\mathrm{A} & 77-79 \%=\mathrm{C}+ \\
90-93 \%=\mathrm{A}- & 74-76 \%=\mathrm{C} \\
87-89 \%=\mathrm{B}+ & 70-73 \%=\mathrm{C}- \\
84-86 \%=\mathrm{B} & 60-69 \%=\mathrm{D} \\
80-83 \%=\mathrm{B}- & <60 \%=\mathrm{F}
\end{array}
$$

\section{Respect and Confidentiality:}

Individuals and individual perspectives will be treated with respect in order to facilitate a safe and civil learning environment for all. Students are asked to maintain a high level of awareness of both the intentions and the effect of their words, and to avoid deliberately using language that is demeaning to others. In addition, when listening to others, mindfully assess both the intent and the effect of their words before assuming an offensive intent.

Respect and civility is the standard for all communications in the class, including discussions, online discussion on D2L, papers, emails, and group projects. Any papers using oppressive language (sexist, racist, homophobic or otherwise inappropriate expressions) will be returned for revision.

In respecting one another's experiences and creating a safe environment, students should maintain confidentiality at all times. Students' individual experiences regarding class may be discussed with friends and colleagues outside of class. However, students may not discuss other students' experiences, and must refrain from using any identifying information about their colleagues. 
Accommodations for Learning Differences: Please discuss any disabilities, learning style challenges or other needs as soon as possible with the instructor. Students with documented disabilities should also contact the Disability Resource Center.

"The role of the artist is to make the revolution irresistible." — Toni Cade Bambara.

Academic Integrity: Students are expected to maintain the highest standards of academic integrity. Plagiarism will be reported to the Office of Student Affairs and will result in a zero on any relevant assignments.

Support Services: Students who desire assistance with writing, formatting, or proofreading can visit the PSU Writing Center. This is important for all written work. This is a free resource, though it does get busy towards the end of the term so it is important to make appointments early. Students may schedule regular appointments for assistance throughout the term. The link is http://www.writingcenter.pdx.edu/index.php.

Students who need assistance locating resources should consult the PSU Millar Library. In consultation with a Hatfield School MPA graduate in Nonprofit Management, the Millar Library has posted the Nonprofit Research and Resource Guide. The link is http:// guides.library.pdx.edu/home. 
Course Schedule

\begin{tabular}{|c|c|c|}
\hline Date & Topics \& Guiding Questions & Assignments \\
\hline $\begin{array}{l}\text { Week 1 } \\
9 / 25\end{array}$ & $\begin{array}{l}\text { Introduction to Civic } \\
\text { Engagement } \\
\text { What civic engagement looks } \\
\text { like } \\
\text { What is civic engagement? } \\
\text { How do we know if we are } \\
\text { engaged? }\end{array}$ & $\begin{array}{l}\text { Required: } \\
\text {-No required readings } \\
\text { Recommended: } \\
\text {-A Guide to Naturalization D2L } \\
\text {-Corporation for National \& Community } \\
\text { Service, "Civic Life in America: Key Findings } \\
\text { on the Civic Health of the Nation" D2L }\end{array}$ \\
\hline $9 / 27$ & \begin{tabular}{|l|} 
Civic Engagement and \\
Disengagement \\
Past experiences shaping our \\
civic behavior \\
How will we operate as a class \\
together? What is engaging \\
and what is disengaging?
\end{tabular} & $\begin{array}{l}\text { Required: } \\
\text {-Tocqueville, "The Use Americans Make of } \\
\text { Public Associations in Civil Life," Chapter Five } \\
\text { of Democracy in America D2L. Briefly } \\
\text { research who Tocqueville is and the historical } \\
\text { context of this reading. } \\
\text {-Prezi: Foundations of U.S. Democracy and } \\
\text { Importance of Civic Engagement D2L }\end{array}$ \\
\hline $\begin{array}{l}\text { Week } 2 \\
10 / 2\end{array}$ & $\begin{array}{l}\text { Power and Privilege in Civic } \\
\text { Engagement } \\
\text { The privilege to engage } \\
\text { Who has the privilege to } \\
\text { engage civically? What } \\
\text { principles guide us as civic } \\
\text { leaders to make engagement } \\
\text { inclusive? } \\
\text { What is "emergence" in the } \\
\text { context of civic engagement? } \\
\text { Form readings discussion } \\
\text { groups and assign who will } \\
\text { facilitate when }\end{array}$ & $\begin{array}{l}\text { Required: } \\
\text {-Jay Smooth Video, "How I Learned to Stop } \\
\text { Worrying and Love Discussing Race” D2L } \\
\text {-Armstrong, “An Okanagan Worldview of } \\
\text { Society” D2L } \\
\text {-Adrienne Maree Brown video, "Excerpt from } \\
\text { Emergent Strategy" } \\
\text {-Introduction to A Force More Powerful D2L } \\
\text { DUE: CBL List of Options } \\
\text { Recommended: } \\
\text {-Portland Civil Rights: Lift Ev'ry Voice (2015 } \\
\text { PBS Documentary) D2L } \\
\text {-Peggy McIntosh, "White Privilege: Unpacking } \\
\text { the Invisible Knapsack” D2L }\end{array}$ \\
\hline
\end{tabular}




\begin{tabular}{|c|c|c|}
\hline Date & Topics \& Guiding Questions & Assignments \\
\hline $10 / 4$ & $\begin{array}{l}\text { Power and Privilege } \\
\text { What roles do power and } \\
\text { privilege play in civic } \\
\text { engagement? }\end{array}$ & $\begin{array}{l}\text { Required: } \\
\text {-Skim for main argument and evidence: } \\
\text { Uslander and Brown, "Inequality, Trust, and } \\
\text { Civic Engagement" D2L } \\
\text {-Loeb, The Impossible Will Take a Little While, } \\
\text { Introduction, pp. 1-17 } \\
\text {-Loeb, chs. 38-39, } 42 \\
\\
\text { Recommended: } \\
\text {-Skocpol, "Voice and Inequality" D2L }\end{array}$ \\
\hline \begin{tabular}{|l} 
Week 3 \\
$10 / 9$
\end{tabular} & $\begin{array}{l}\text { Participatory Democracy } \\
\text { Showing up for civic } \\
\text { Engagement } \\
\text { What is participatory } \\
\text { democracy? } \\
\text { What is social capital and } \\
\text { what is its role in civic } \\
\text { engagement? } \\
\text { Reading Group 1 }\end{array}$ & $\begin{array}{l}\text { Required: } \\
\text {-Macat Politics Analysis video, “An } \\
\text { Introduction to Robert Putnam's Bowling } \\
\text { Alone” D2L } \\
\text {-Putnam, "Bowling Alone: America's Declining } \\
\text { Social Capital" D2L } \\
\text {-Research online an example of participatory } \\
\text { democracy being practiced by a community or } \\
\text { government. Come to class ready to share the } \\
\text { example and your sense of what "participatory } \\
\text { democracy" means. } \\
\text { Recommended: } \\
\text {-Voter registration for new Oregon voters } \\
\text { (deadline 10/16) }\end{array}$ \\
\hline 10/11 & $\begin{array}{l}\text { Participatory Democracy } \\
\text { Facilitating participation } \\
\text { What facilitates participation? }\end{array}$ & $\begin{array}{l}\text { DUE: Dis/Engagement Baseline Narrative } \\
\text { Recommended: } \\
\text {-Sandel, Democracy's Discontent }\end{array}$ \\
\hline $\begin{array}{l}\text { Week } 4 \\
10 / 16\end{array}$ & $\begin{array}{l}\text { Deliberative Democracy } \\
\text { Disagreement is inevitable in } \\
\text { participation...so use it } \\
\\
\text { What blocks dialogue and } \\
\text { deliberation in a democracy? }\end{array}$ & $\begin{array}{l}\text { Required: } \\
\text {-Palmer, “Introduction” and “Democracy's } \\
\text { Ecosystem” D2L } \\
\text {-Friedman, “Reframing Framing” D2L }\end{array}$ \\
\hline
\end{tabular}




\begin{tabular}{|c|c|c|}
\hline Date & Topics \& Guiding Questions & Assignments \\
\hline $10 / 18$ & $\begin{array}{l}\text { Deliberative Democracy } \\
\text { Deliberation, debate, and } \\
\text { discussion in civic engagement } \\
\text { What tools do we have for } \\
\text { deliberation? } \\
\text { Reading Group } 2\end{array}$ & $\begin{array}{l}\text { Required: } \\
\text {-Covey, "Using Empathetic Listening to } \\
\text { Collaborate" D2L } \\
\text {-Rosenberg Video, "Nonviolent } \\
\text { Communication Part 1" D2L } \\
\text {-Lappe, "Free Your Eco-Mind" D2L } \\
\text {-Research online an example of deliberative } \\
\text { democracy being practiced by a community or } \\
\text { government. Come to class ready to share the } \\
\text { example and your sense of what "deliberative } \\
\text { democracy" means generally. } \\
\\
\text { Recommended: } \\
\text {-Fung, "Putting the Public Back into } \\
\text { Governance: The Challenges of Citizen } \\
\text { Participation and its Future" D2L } \\
\text {-Putnam, Making Democracy Work }\end{array}$ \\
\hline $\begin{array}{l}\text { Week } 5 \\
10 / 23\end{array}$ & $\begin{array}{l}\text { Community \& Local Civic } \\
\text { Engagement } \\
\text { When it is time to act } \\
\text { Field Trip }\end{array}$ & $\begin{array}{l}\text { Required: } \\
\text {-Beavan, "Advice from an Accidental Activist" } \\
\text { D2L } \\
\text {-Schloredt, "Boulder Votes to Free Its Electric } \\
\text { Company," D2L } \\
\text {-Schor, "Less Work, More Living" D2L }\end{array}$ \\
\hline $10 / 25$ & $\begin{array}{l}\text { Community \& Local Civic } \\
\text { Engagement } \\
\text { Principles and models } \\
\text { Reading Group } 3\end{array}$ & $\begin{array}{l}\text { Required: } \\
\text {-Lappé, "Doing Democracy: Ten Practical } \\
\text { Arts" D2L } \\
\text {-Choose a news article about an issue where } \\
\text { you live. Try to find an article that offers a new } \\
\text { perspective, whether it be critical, creative, or } \\
\text { political. Come ready to share in your reading } \\
\text { group. }\end{array}$ \\
\hline
\end{tabular}




\begin{tabular}{|c|c|c|}
\hline Date & Topics \& Guiding Questions & $\overline{\text { Assignments }}$ \\
\hline \begin{tabular}{|l|} 
Week 6 \\
$10 / 30$
\end{tabular} & $\begin{array}{l}\text { Putting It Together: } \\
\text { Privilege + Participation + } \\
\text { Deliberation + Local } \\
\text { Engagement } \\
\text { In-class Ballot Party and } \\
\text { international guests } \\
\text { Guests in class. }\end{array}$ & $\begin{array}{l}\text { Required: } \\
\text {-Candidates and Measures on the November } \\
2018 \text { Ballot D2L } \\
\text {-Additional research on candidates and } \\
\text { measures as needed to understand them for } \\
\text { yourself. }\end{array}$ \\
\hline $11 / 1$ & $\begin{array}{l}\text { Leadership for Civic } \\
\text { Engagement } \\
\text { What qualities of leadership } \\
\text { are needed to create social } \\
\text { change? } \\
\text { Reading Group } 4\end{array}$ & $\begin{array}{l}\text { Required: } \\
\text {-Loeb, Ch. 6, 8, } 9 \\
\text {-Excerpt from Dweck, Mindset, D2L } \\
\text { Recommended: } \\
\text {-Wheatley, chapters from Leadership and the } \\
\text { New Science D2L } \\
\text {-Fairholm, “Different Perspectives on the } \\
\text { Practice of Leadership” D2L } \\
\text {-Senge, The Fifth Discipline } \\
\text {-Rath \& Conchie, Strengths Based Leadership }\end{array}$ \\
\hline $\begin{array}{l}\text { Week } 7 \\
11 / 6\end{array}$ & $\begin{array}{l}\text { Contextualizing Civic } \\
\text { Experiences }\end{array}$ & $\begin{array}{l}\text { DUE: Contextualization of Dis/Engagement } \\
\text { Narrative }\end{array}$ \\
\hline $11 / 8$ & $\begin{array}{l}\text { Civic Action } \\
\text { Collective action and policy } \\
\text { change }\end{array}$ & $\begin{array}{l}\text { Required: } \\
\text {-Palmer, "The Unwritten History of the Heart" } \\
\text {-Linzey, "Sins of the Fathers" Speech D2L } \\
\text {-Loeb, ch. } 32 \\
\text { Recommended: } \\
\text {-Sugar Hill, NH ordinance on sustainable } \\
\text { energy future and right to self-governance D2L } \\
\text {-Goodwyn, "Introduction" from The Populist } \\
\text { Moment D2L }\end{array}$ \\
\hline
\end{tabular}




\begin{tabular}{|c|c|c|}
\hline Date & Topics \& Guiding Questions & Assignments \\
\hline \begin{tabular}{|l|} 
Week 8 \\
$11 / 13$
\end{tabular} & $\begin{array}{l}\text { Civic Action } \\
\text { Art, technology, and action } \\
\text { How do technologies facilitate } \\
\text { or hinder civic participation? } \\
\text { How is art used for } \\
\text { community engagement and } \\
\text { expression? } \\
\text { Reading Group } 5\end{array}$ & $\begin{array}{l}\text { Required: } \\
\text {-Find one example of what you think is a } \\
\text { successful use of the arts for civic engagement. } \\
\text { Come prepared to share in a small group. } \\
\text {-Fredrickson, "Your Phone vs. Your Heart" } \\
\text { D2L } \\
\text {-Watch Annie Leonard video, The Story of } \\
\text { Change and explore website D2L } \\
\text {-Pahlka TED Talk, "Coding a Better } \\
\text { Government" D2L } \\
\text {-Squire video, "Civic Engagement through } \\
\text { Digital Games" D2L }\end{array}$ \\
\hline $11 / 15$ & $\begin{array}{l}\text { Power and Engagement } \\
\text { Claiming power and choosing } \\
\text { actions }\end{array}$ & $\begin{array}{l}\text { Required: } \\
\text {-TED Interview with Alicia Garza, Patrisse } \\
\text { Cullors and Opal Tometi } \\
\text {-New Yorker article, "Holy Rage: Lessons from } \\
\text { Standing Rock" } \\
\text {-Loeb, Ch. 48-50, } 55 \\
\text { Recommended: } \\
\text {-"7 Times in History When Students Turned to } \\
\text { Activism" D2L }\end{array}$ \\
\hline \begin{tabular}{|l|} 
Week 9 \\
$11 / 20$
\end{tabular} & $\begin{array}{l}\text { Power and Engagement } \\
\text { Revisiting disengagement }\end{array}$ & $\begin{array}{l}\text { DUE: Final Narrative-Bring a hard copy to } \\
\text { class (paper clipped not stapled please) }\end{array}$ \\
\hline \begin{tabular}{|l} 
Week 10 \\
$11 / 27$
\end{tabular} & $\begin{array}{l}\text { Introduction to Civic } \\
\text { Engagement, Revisited } \\
\text { Reviewing, mapping, modeling } \\
\text { engagement }\end{array}$ & $\begin{array}{l}\text { Required: } \\
\text {-Macy, "The Great Turning as Compass and } \\
\text { Lens" D2L } \\
\text {-Macy video, "The Gifts of Uncertainty" D2L } \\
\text { Recommended: } \\
\text { Meadows, "Leverage Points" }\end{array}$ \\
\hline
\end{tabular}




\begin{tabular}{|c|c|c|}
\hline Date & Topics \& Guiding Questions & Assignments \\
\hline $11 / 29$ & $\begin{array}{l}\text { Visions of Civic Engagement } \\
\text { Going forward } \\
\text { How can we unite the theories } \\
\text { from class into our own } \\
\text { philosophy of engagement for } \\
\text { the common good? How can } \\
\text { we move forward? }\end{array}$ & $\begin{array}{l}\text { Required: } \\
\text {-Hawken, "You Are Brilliant and the Earth is } \\
\text { Hiring" D2L } \\
\text {-Leguin, "Those Who Walk Away from } \\
\text { Omelas" } \\
\text { DUE: CBL Event \& Civic Engagement } \\
\text { Context Maps due and presented in small } \\
\text { groups }\end{array}$ \\
\hline
\end{tabular}


APPENDIX B: Course One Narrative Part One Assignment Description

\section{PA 311U}

\section{Dis/Engagement Baseline Narrative}

Due in class, Thursday, October 11. This is a 2-3 page narrative explanation of the engagement mapping exercise we do in class.

This short paper is intended to spur reflection on your own engagement and disengagement. Reflecting on ourselves, without judgment, is an important first step in developing an understanding of what is engaging and disengaging to others-a key topic of this course.

Please respond to the following questions in your paper:

- What is one experience of engagement that you have had in your life?

$\circ$ What was the context of that experience?

- In what "area of life" was the experience? (e.g. Education, Community Service, Family, etc.)

$\circ$ What values of yours were you expressing as you had that engaging experience?

- Think about what made it engaging for you and be as honest and thoughtful as you can in explaining this. This question should take a full paragraph to answer.

- What are two experiences of disengagement you have had in your life?

$\circ$ What was the context of each experience?

- In what "area of life" was the experience? (e.g. Education, Community Service, Family, etc.)

$\circ$ What values of yours were you expressing when you ended up having the disengaging experiences? In other words, what were you hoping for?

$\circ \quad$ Think about what made each experience disengaging for you and be as honest and reflective as you can in explaining this. Each experience should get a full paragraph please. 


\section{Suggested Outline}

Paragraph 1: Engaging experience

. Context, "area of life," and values underlying the experience

Paragraph 2: Engaging experience explanation

. Why it was engaging

Paragraph 3: First Disengaging experience

- Context, "area of life," and values underlying the experience

Paragraph 4: First disengaging experience explanation

- Why it was disengaging

Paragraph 5: Second Disengaging experience

- Context, "area of life," and values underlying the experience

Paragraph 6: Second disengaging experience explanation

- Why it was disengaging

Paragraph 7: Brief Conclusion about how you think this informs your civic life 
APPENDIX C: Course One Narrative Part Two Assignment Description

\author{
PA 311U Fall 2018 \\ Contextualization of Dis/Engagement Narrative
}

\title{
Due by THURSDAY, November 8 (not Tuesday 11/6) in class
}

The aim of this second stage of the Narrative Assignment is to bring more contextual understanding to a disengaging experience, possibly one you wrote about in the Baseline Narrative.

This assignment uses the format of a letter, which makes it more creative. It also asks you to draw on three readings, videos, or class activities. You are blending creative and academic writing here to make use of the benefits of both forms. Ask me if you have questions.

Assignment Summary: Write a letter to a disengaged version of yourself. Give this version of you empathy, using Nonviolent Communication as a guide (green handout). Draw on three readings/videos/class activities to explain to them the larger context of their experience of disengagement. Reflect on what this version of you needs in order to engage going forward in something you deeply care about.

Assignment Components:

- Use the format of a letter to yourself.

- Select an experience that was disengaging for you. This may be something you've already written about and may not be. Try to find an instance that you don't feel $100 \%$ resolved or clear about so that the assignment is fruitful. \{Introduce and summarize the experience in a paragraph.\}

- Reflect on what needs and feelings this version of you was having. Refer to the green NVC handout. If you like, do the same for others in the experience. \{Write about the feelings and needs in 1-2 paragraphs.

- Given the feelings and needs, choose three class readings, videos or activities that you think would help this version of you to understand their experience. For each reading/video/activity, write a paragraph telling this version of you $\{3$ paragraphs total\}: 
- What the reading says that you think is relevant to the experience you had of disengagement.

- What you got out of the reading.

- Why this particular reading is something you're choosing to share in this letter.

- $\quad$ Finish by writing to this version of yourself what you think they specifically (given their feelings, needs, values or skills) would contribute to something you care deeply about, and why. What else, in addition to this letter, might they need in order to engage? $\{1-2$ paragraphs. $\}$ 


\section{APPENDIX D: Course One Narrative Part Three Assignment Description}

\section{PA 311 Fall 2018 Final Paper Assignment}

Please write a 4-page paper that synthesizes course learning. Please respond to the following four prompts in your paper:

1. A Civic Vision. What is something you find deeply important and wish to see in our civic world? This could be a kind of relating, a process, a set of values, a policy approach, etc.

2. Leadership for Civic Vision. What qualities of leadership are needed to move toward this vision? What qualities do you think need to be embodied to realize the vision?

3. Your Personal Engagement in the Civic Vision. Where do you perceive your challenges lie in taking action toward the vision?

4. Contextualizing Challenges. Drawing on class readings, activities, and your learning over the term, what context can you bring to the challenges you wrote about in \#3? How would you bring compassionate insight to those challenges?

This paper should be concise, thoughtful, and carefully expressed. Final papers should be typed, double spaced, use 12-point font, 1-inch margins, and written in APA or Chicago in-text format.

The deadline for the paper is in class on Tuesday, November 20th.

This is how points for the paper will be distributed.

\begin{tabular}{|l|l|}
\hline $\begin{array}{l}\text { Meaningfully incorporates at least five class readings, but ideally refers } \\
\text { to } 6-9 \text { readings from class. Shows reflection/analysis and response to } \\
\text { all references. }\end{array}$ & 7 \\
\hline $\begin{array}{l}\text { Makes a thoughtful and compelling argument for two key elements that } \\
\text { encourage civic engagement. (Please remember to explain what you } \\
\text { mean when you refer to each element, possibly using written sources in } \\
\text { addition to your own thinking). }\end{array}$ & 9 \\
\hline $\begin{array}{l}\text { Explains what factor you think is most important in allowing and } \\
\text { encouraging your own civic engagement, and why. (This section can be } \\
\text { written honestly with a somewhat less formal tone, but should still refer } \\
\text { meaningfully to readings that may have shaped your ideas on this.) }\end{array}$ & 5 \\
\hline $\begin{array}{l}\text { Uses a clear writing style that maximizes the reader's intake of your } \\
\text { ideas. This includes clear citation when using others' ideas. Includes a } \\
\text { references page. }\end{array}$ & 4 \\
\hline
\end{tabular}




\begin{tabular}{|l|l|l|}
\hline Total & 25 \\
\hline
\end{tabular}

A suggestion of how to use the page space:

$-1 / 2$ page Intro-outline your coming points and suggest why what you're saying is important

-1 page -explain first element that is essential for civic engagement, weaving in readings, activities from class

-1 page -explain second element that is essential for civic engagement, weaving in readings, activities from class

-1 page-explain what you think most influences or motivates your own civic engagement $-1 / 2$ page Conclusion-reiterate your three points and suggest some goals you have for yourself or society going forward; revisit why what you have written is important to our society 
APPENDIX E: Course One Community Based Learning Final Assignment Description

PA 311 Fall 2018

\section{CBL Event \& Civic Engagement Concept Maps Due Thursday 11/29}

Please synthesize your CBL experience and course learning in the form of a concept map. Drawing on course readings and concepts, place your CBL events in the context of civic engagement as you have come to understand it. Maps can be created with technology or by hand - they need to demonstrate thoughtful connections you have made between

readings, events, and ideas. The maps will be shared in presentations to a small group.

Review your class notes and readings to map your own answers to the following: What three elements are most essential to have in place in order to encourage a high level of civic engagement in society? Course materials and discussions have suggested numerous possible answers to these questions, but here you map out your own understanding of why three of these answers are essential or foundational.

Your map should name the specifics of your CBL events (name of event, organization, day, time, etc.). More importantly though, your map shows how your observations of the events fit into your larger understanding of civic engagement. One entry point for this reflection is the question: How did the event demonstrate, or not demonstrate, the principles you think are key in encouraging engagement?

The deadline for the map is in class on Thursday, November 29th. 
APPENDIX F: Course Two Syllabus

PA 313

PA 313U: Fundamentals of Public Service

Instructor Information

Instructor: Jane Carr

Division of Public Administration

Email: jacarr@pdx.edu (Not D2L mail)

Office Hours: By appointment, in person or by phone. Please email to schedule.

\section{Course Description:}

This course explores the field of Public Administration and its foundational and shifting frameworks as well as its role in valuing democracy, citizenship and the public interest. Students will examine the historical dimensions and underlying values that shape the social and political arrangements within the contemporary public service field. Students will develop an understanding of the competing criteria for measuring "success" in the public sector and will identify ways for public administrators to enable citizen engagement as well as generate ideas for community members to influence and inform public policy through civic engagement and public discourse.

In addition, we will examine democracy and citizen engagement through different lenses. Case study discussions and the public service inquiry project will enable us to translate the theoretical course reading to the practical challenges of everyday democracy. If you have taken PA311U and/or PA312U, you learned about civic engagement and/or civic leadership from the informed citizen perspective. This course shifts the lens to the public administrator view to help us understand how and why bureaucracy operates the way it does, as well as gain insight into various theoretical and philosophical approaches in public sector service.

\section{Course Objectives:}

By the end of this course, students should be able to:

- Describe foundational frameworks underpinning public service from the historical perspective;

- Describe and differentiate among contemporary major administrative frameworks used in the public sector:

- List ideal leadership characteristics for public administrators

- Actively engage in small group discussions to analyze case studies in public service

- Articulate specific ways that public sector administrators can enable citizen engagement

- Actively design, participate in, analyze and report on a community-based learning project 
- Demonstrate synthesis of course concepts through written reflection about your project

\section{Civic Leadership Minor:}

The interdisciplinary Civic Leadership minor in the Mark O. Hatfield School of Government provides students with theoretical and practical understanding about civic leadership and prepares students to be responsibly engaged citizens and community leaders. For more information see: Civic Leadership Minor.

Civic Leadership Programmatic Learning Objectives:

1. Describe, analyze and apply leadership theories and concepts to historical, current, societal and personal contexts.

2. Explain governance, social, and political mechanisms for facilitating social change.

3. Demonstrate an understanding of individual and collective ethics and responsibility to multiple communities, cultures and political constituencies.

4. Apply the theories of leadership to multiple social issues in varied community and cultural contexts through community engaged learning and projects.

5. Think critically and self-reflectively about personal roles in social and political structures.

6. Conceptualize and develop opportunities for learning and application of public service aims through various applied, structured learning activities.

7. Synthesize concepts of leadership, collaboration, community engagement, culture, social capital and social justice.

8. Critically reflect upon the applicability of relevant theories and frameworks in contemporary civil society.

\section{Overarching University Studies Learning Goals:}

- Inquiry and Critical Thinking - Students will learn various modes of inquiry through interdisciplinary curricula - problem-posing, investigating, conceptualizing in order to become active, self-motivated, and empowered learners.

- Communication - Students will enhance their capacity to communicate in various ways - writing, graphics, numeracy, and other visual and oral means - to collaborate effectively with others in-group work, and to be competent in appropriate communication technologies.

- The Diversity of the Human Experience - Students will enhance their appreciation for and understanding of the rich complexity of the human experience through the 
study of differences in ethnic and cultural perspectives, class, race, gender, sexual orientation, and ability.

- Ethics and Social Responsibility - Students will expand their understanding of the impact and value of individuals and their choices on society, both intellectually and socially, through group projects and collaboration in learning communities.

\section{Course Information}

\section{Course Engagement:}

Your engagement in this course is critically important. Consider this your opportunity for academic citizenship as part of your life at PSU - an institution of higher education. You are responsible for coming to the virtual classroom prepared to ask questions, provide insight and alternative perspectives to concepts under discussion, and add personal "real world" case examples when appropriate to enhance material covered through assigned reading and online and in class dialogue. You are expected to be an active interpreter and synthesizer through careful reading of the course materials and discussions providing constructive feedback to the work and commentary presented and discussed by peers and the instructor. In other words, you are responsible for being an active participant and coproducer of learning opportunities for yourself and others. In short, you are responsible for putting into practice, the values and noble elements of public service that one should expect of stewards of the public interest.

\section{Course Readings:}

I may be refining the required readings as we go. Please be aware of this and know that I will not expect you to be responsible for readings posted less than ten days before the deadline. I make every effort to give you only readings that I find core to our topic at hand. Additional reading suggestions are provided in most weeks to guide you toward deeper study and a wider array of significant perspectives, if you choose.

\section{Community Based Learning Component:}

CBL courses encourage students to apply theories and classroom learning to real world situations that impact communities. CBL courses acknowledge that insights and understandings about key course themes are located in multiple places, including in students' life experiences, the classroom, and the community. This course's CBL component asks students to engage in community work within an area of interest. This involves an investment not only in a deep and empathetic understanding of one's world, but also in the complex process of identifying one's own values and life goals.

In CBL courses, students formally represent the university, the instructor, the host community partners, and themselves both inside and outside the classroom. Professional behavior is expected at all times. 


\section{Course Requirements}

\section{Required Texts:}

- $\quad$ Denhardt \& Denhardt. (2015). The New Public Service: Serving, Not Steering, 4th edition.

- Dalai Lama. (2018). A Call for Revolution: A Vision for the Future. (Note: Please contact the instructor if you need an alternative to this text.)

\section{Course Assignments:}

- Reading discussion within small group on D2L (15\%). Throughout the term, please post a response to the week's readings in your group's discussion forum. These posts are intended to provide accountability for completing the readings, and give you an opportunity for dialogue. However, they also serve as a resource for the group member(s) posting to the public-facing website that week (see below).

- Posts to public-facing website (40\%). Many of the assignments for this course take the form of creating content for our class website "Living Principles of Public Service." This site, when complete, will serve as a valuable resource for people new to working in public service. Each student will contribute five posts over the course of the term. Please note: You can use a pseudonym to post if you are not comfortable using your name. Just make sure I know what your pseudonym is.

- $\quad$ Post 1: With reference to the class text, choose one of the three frameworks: Old Public Administration, New Public Management, or New Public Service. Create a description of this framework and post it on the corresponding page. You will see links to the three pages under the heading "Three Frames for Understanding Public Service" on the Welcome page. This post will help users of the website understand these three key frames. This post could take the form of written text, video, or another format that best communicates your content. These are due in Week Two.

- $\quad$ Posts 2 and 3: Based on a schedule you work out with your group, 1-2 group members each week will post on the public-facing website under the "Principles of Public Service" section. Each principle is covered in one week of the course and has its own page on the site. This assignment asks you to summarize the week's reading and relate it to an example that you find in the world or on the internet. The goal is to shed light on what it 
means to apply this principle to public service. The example you choose can demonstrate an application or a lack of application of the principle. The form of these posts can be written, video, or another form based on what will best convey your content. Please link to, or insert the example, in your post.

- $\quad$ Post 4: This is a summary of your Personal Public Service Reflections. After completing these assignments, please create a summary for the site page "Stories of Service" so that users can benefit from your insights about your challenges and growth.

- Post 5: This is a summary (written, video, etc.) of your Public Inquiry Project. That project asks you to interview a public servant working in an area that interests you. Your full report takes the form of an essay (see below). After completing that essay, please summarize your key findings for the section of the website "Public Servant Case Studies" so that site users can benefit from your research.

- Personal Public Service Reflections = 20\%. In Week Three and Week Seven, you will write short papers about your own goals and growth for being of service. These are honest and informal in tone, but rigorous and challenging in their scope.

- Public Inquiry Project $=\mathbf{2 5 \%}$. The public service inquiry project is composed of a) selecting a public sector or non-profit organization, b) arranging an interview, and c) giving your time or effort to the organization to further your learning and contribute. Follow your particular interest or passion. Some examples include an agency of local government, a board, a community group, a local nonprofit group or even a private firm that carries out public responsibilities in partnership with a government and/or other public or nonprofit organizations. The organization you select must have a developed public website. You should plan to contact a key decision-maker within your organization of choice, such as an agency head, executive director or program manager or point person in charge of a particular public policy or issue of concern of which the agency is currently concerned. Our main focus is on agencies engaged in partnership building to solve a public problem and the arrangements for engaging citizens. The public service project paper is a report of observations, findings, and analysis connected to concepts from the reading and course material about your organization selected. This should include information gained about your selected organization from the interview, written material on the website or other sources. The paper minimum length is 5-7 pages. 


\section{Final Grades:}

Students will be graded on a percentage scale out of 100 points.

- $\quad 94-100 \%=\mathrm{A}$

- $90-93 \%=\mathrm{A}-$

- $87-89 \%=\mathrm{B}+$

- $84-86 \%=\mathrm{B}$

- $80-83 \%=\mathrm{B}-$

- $77-79 \%=\mathrm{C}+$

- $74-76 \%=\mathrm{C}$

- $70-73 \%=\mathrm{C}-$

- $60-69 \%=\mathrm{D}$

- $<60 \%=\mathrm{F}$

\section{Evaluation:}

Students are expected to complete all requirements for the course in order to receive a grade. Grades are assigned based on points earned for each assignment. Details about expectations and evaluation of specific assignments will be included in the corresponding handouts. Please let me know if you are consistently spending more than eight hours per week on the class readings and assignments.

\section{Expectations for Written Assignments:}

- $\quad$ Care and attention: Students are expected to take care with assignments, including neatness, proofreading, and looking up uncertain words or grammar rules. If inattention interferes with reading of the work, assignments may be returned to students for revision prior to grading.

- $\quad$ Final Paper format: Final papers should be typed, double spaced, use 12-point font, 1-inch margins, and written in APA or Chicago format. Assignments may be submitted in Dropbox on D2L. Students who need guidance on formatting and style guide should refer to The OWL at Purdue University.

- Deadlines: Deadlines, including those for online submissions, are firm. If you require an extension, please request this with at least one week's notice. Without prior permission, assignments will lose one partial letter grade (A to A-) for every day the assignment is overdue.

\section{Policies}

\section{Respect and Confidentiality:}


Individuals and individual perspectives will be treated with respect in order to facilitate a safe and civil learning environment for all. Students are asked to maintain a high level of awareness of both the intentions and the effect of their words, and to avoid deliberately using language that is demeaning to others. In addition, when listening to others, mindfully assess both the intent and the effect of their words before assuming an offensive intent.

Ideas, not individuals, are open to challenge. The rich nature of the discussions is likely to raise opposing points of view. You should feel comfortable being your own advocate concerning the ideas and thinking of others, though that challenge cannot disparage the personal views of your colleagues. Respect and civility is the standard for all communications in the class, including online discussion on D2L, papers, emails, and group projects. Any papers using oppressive language (sexist, racist, homophobic or otherwise inappropriate expressions) will be returned for revision.

In respecting one another's experiences and creating a safe environment, students should maintain confidentiality at all times. Students' individual experiences regarding class may be discussed with friends and colleagues outside of class. However, students may not discuss other students' experiences, and must refrain from using any identifying information about their colleagues.

\section{Accommodations for Learning Differences:}

It is Portland State University's goal that learning experiences be as accessible as possible. If you anticipate or experience physical or academic barriers based on disability, please register with the Disability Resource Center (DRC) (503-725-4150 or drc@pdx.edu) in order to establish reasonable accommodations. Once you have registered with the DRC, please schedule a time to talk to me so that we can discuss your needs for the term.

\section{Academic Integrity:}

Students are expected to maintain the highest standards of academic integrity. Plagiarism will be reported to the Office of Student Affairs and will result in a zero on any relevant assignments.

\section{Support Services:}

Students who desire assistance with writing, formatting, or proofreading can visit the PSU Writing Center. This is important for all written work. This is a free resource, though it does get busy towards the end of the term so it is important to make 
appointments early. Students may schedule regular appointments for assistance throughout the term.

Students who need assistance locating resources should consult the PSU Millar Library. In consultation with a Hatfield School MPA graduate in Nonprofit Management, the Millar Library has posted the Nonprofit Research and Resource Guide. The link is: $\underline{\text { PSU }}$ Library Research Guides \& Tutorials.

\section{Advising:}

For advising information, Casey Campbell (casec@pdx.edu) or Elizabeth Benner (ebenner@pdx.edu), the Academic Advisors in the College of Urban and Public Affairs may be contacted. To schedule an appointment please email or call 503-725-9210. The new advising center is located in the URBN building 540E. Students are also highly encouraged to discuss their course selection and plan of study with the instructor.

\section{Course Schedule}

Please note: this syllabus is a living document, so may be subject to change. While I as your instructor will make every effort to adhere to the information below, there may be instances where individual items may change or are adjusted. If this should be the case, I will make you aware of this as soon as possible.

\section{Week \\ Readings/Videos \\ Assignments}

\section{Week One: Introductions}

\section{Public Administration and the New Public Management}

\section{(April 1-7)}

- Who are we as a class?

- How is this class laid out?

- What is "Old Public Administration" and what is the legacy of this philosophy?

- What is "New Public Management" and what is the legacy of this philosophy?

- Why do the frameworks and philosophies underlying public work matter?

\section{Required:}

- Instructor video introducing class

- $\quad$ Denhardt \& Denhardt: Preface \& Chapter 1

\section{Recommended:}

- $\quad$ Peter Levine blog "What is the Definition of Civic Engagement?"

- Fun videos on public administration stereotypes

- $\quad$ Syllabus quiz

- Introductory video post 
See Week One Module for details and complete list.

\section{Week Two: Roots of the New Public Service}

(April 8-14)

- What is the "New Public Service" and why would this framework be useful?

- What are the philosophical roots of New Public Service?

- How have ideas about democratic citizenship, community, and civil society evolved over time in the U.S.?

\section{Required:}

- $\quad$ Denhardt \& Denhardt: Chapter 2

- Remen: Helping, Fixing or Serving? (Re-read if you read in PA 312)

- Video: Politics-Administration Dichotomy

- Video: Scientific Management

\section{Recommended:}

- $\quad$ Osborne \& Graeber, Reinventing Government

- Week Two discussion post

- Post \#1 Due: Pick OPA, NPM or NPS and create a post describing it for the class site. Due Sunday night April 14 by 11:59pm Pacific Time.

See Week Two Module for details and complete list.

\section{Week Three: Serve Citizens, not Customers}

\section{(April 15-21)}

- What do we mean by the concept of the "public"? How is this different across the three frameworks (OPA, NPM, NPS)?

- What does it mean to "serve the public"?

- What are the implications of having "civic virtue"?

- What is the difference between serving citizens and serving customers?

\section{Required:}

- $\quad$ Denhardt \& Denhardt: Chapter 3

- Brown: People Are Hard to Hate Close Up. Move In.

- Video: The Hawthorne Studies

- Video: Street-Level Bureaucrats

\section{Recommended:}

- Osborne editorial: The New Public Governance?

- Personal Public Service Reflection \#1 due Monday April 22 by 11:59pm Pacific Time.

- Week Three discussion post

- See Week Three Module for details and complete list.

-

Week Four: Seek the Public Interest

(April 22-28)

- What does the "public interest" mean? 
- How to we determine what is in the public interest?

- How does the definition of public interest change through lenses of the normative model, abolitionist view, political process theory, and shared values?

\section{Required:}

- $\quad$ Denhardt \& Denhardt: Chapter 4

- A Call for Revolution: Chapter 1

- Video: The Deliberative Polling Process

\section{Recommended:}

- $\quad$ Chapter 1 from Stone, Policy Paradox

- Week Four discussion post

- If it is your turn: Post \#2/\#3 in Principles of Public Service

- Planning for CBL interview

See Week Four Module for details and complete list.

\section{Week Five: Value Citizenship over Entrepreneurship}

\section{(April 29-May 5)}

- What is the difference between governance and government?

- What does accountability look like? How does it look different in OPA, NPM, and NPS?

- What does it mean to be an Administrator?

\section{Required:}

- $\quad$ Denhardt \& Denhardt: Chapter 5

- A Call for Revolution: Chapter 2

- Week Five reference videos: Imagine Chicago, Many Voices One Community, and Everyday Democracy

\section{Recommended:}

- $\quad$ Stoker: Governance as Theory—Five Propositions

- Week Five discussion post

- If it is your turn: Post \#2/\#3 in Principles of Public Service

- Planning/Interviewing for CBL project

See Week Five Module for details and complete list.

\section{Week Six: Think Strategically, Act Democratically}

(May 6-12)

- How has policy implementation changed over time?

- How does the process of implementation change if seen through OPA, NPM, and NPS?

\section{Required:}

- Denhardt \& Denhardt: Chapter 6

- A Call for Revolution: Chapter 3

- Week Six reference material: Phoenix Blight Buster program

\section{Recommended:}


- Documentary Film: 13 th (Netflix)

- Week Six discussion post

- If it is your turn: Post \#2/\#3 in Principles of Public Service

- CBL Interview complete

See Week Six Module for details and complete list.

\section{Week Seven: Recognize that Accountability Isn't Simple}

\section{(May 13-19)}

- What do we mean by the "classic debate" about accountability?

- Who is accountable to whom and for what?

- How does the aim of accountability change if seen through OPA, NPM, and NPS?

\section{Required:}

- $\quad$ Denhardt \& Denhardt: Chapter 7

- A Call for Revolution: Chapter 4

- Week Seven additional materials: Accountability of Public Officials

\section{Recommended:}

- Documentary Film: Who Killed the Electric Car? (Amazon Prime)

- Personal Public Service Reflection \#2 due Sunday May 19 by 11:59pm Pacific Time.

- Week Seven discussion post

- If it is your turn: Post \#2/\#3 in Principles of Public Service

See Week Seven Module for details and complete list.

\section{Week Eight: Serve Rather than Steer}

\section{(May 20-26)}

- What does public leadership look like, sound like, and feel like?

- How does the practice of public leadership change if seen through OPA, NPM, and NPS?

\section{Required:}

- $\quad$ Denhardt \& Denhardt: Chapter 8

- A Call for Revolution: Chapter 5 \& Charter of Universal Responsibility

- Week Eight discussion post

- If it is your turn: Post \#2/\#3 in Principles of Public Service

See Week Eight Module for details and complete list.

\section{Week Nine: Value People, not just Productivity}

(May 27-June 2)

- What does it mean to "manage through people"?

- How does the goal of motivating people change if seen through OPA, NPM, and NPS?

- How would you redefine the term "productivity" to embody your public service values? 


\section{Required:}

- $\quad$ Denhardt \& Denhardt: Chapter 9

\section{Recommended:}

- Juliet Schor, True Wealth and other articles

- Week Nine discussion post

- $\quad$ Posts 2 \& 3 completed for everyone

See Week Nine Module for details and complete list.

\section{Week Ten: The New Public Service and Citizen Engagement}

(June 3-9)

- What are you taking away from the class readings and material?

\section{Required:}

- Denhardt \& Denhardt: Chapter 10

\section{Recommended:}

- Denhardt \& Denhardt: Chapters 11 \& 12

- $\quad$ Post 4 Due

See Week Ten Module for details and complete list.

\section{Week Eleven: Wrapping Up}

(June 10-16)

- What did you learn from the CBL project, the Personal Public Service reflections, and the class readings?

None

Due Monday, June 10 11:59 PM PST:

- Public Inquiry Project \& Paper

Due Wednesday, June 12 11:59 PST:

- Post 5 Due

- Complete Course Evaluation

See Week Eleven Module for details and complete list.

Course Learning Map

Please review the Course Learning Map for details. 


\section{APPENDIX G: Course Two Narrative Part One Assignment Description}

\section{Personal Public Service Reflection \#1}

2-3 pages, 12-point Times or equivalent, 1-inch margins, double-spaced.

Due Monday, April 22, by 11:59pm Pacific time. Please submit as a document (not PDF) under Assignments. (Note: This is due on a Monday rather than the normal Sunday.) Though the tone is personal and you will use "I" throughout, it is also rigorous, and asks you to reflect deeply and honestly.

This short paper is intended to spur reflection on your own experiences of being helped/ fixed and served. It is based on the framework from Dr. Remen's three-page article, which I recommend you review. Reflecting on ourselves, without judgment, is an important first step in developing our understanding of and capacity for service.

Citations are not required for this paper, but feel free to use them!

Using the descriptions from Remen of the terms "helping," "fixing" and "serving," please respond to the following questions in your paper:

- What is one experience of being "fixed" or "helped" that you have had in your life?

- What was the context of that experience? What were your aims or intentions?

- Upon what values were you acting in the situation? What feelings were you experiencing?

- Do you think you were being helped or fixed? Or perhaps some combination? Why do you think this was helping or fixing?

- Think about what impact this had on you and be as honest and thoughtful as you can in explaining this. What was the impact at the time? What is the impact on you now? This question should take close to a page to answer.

- What is one experience of being "served" that you have had in your life?

- What was the context of that experience? What were your aims or intentions?

- Based on what values were you acting in the situation? What feelings were you experiencing?

- Why do you think this experience was an experience of being "served"? Think about what impact this had on you and be as honest and thoughtful as you can in explaining this. What was the impact at the time? What is 
the impact on you now? This question should take close to a page to answer.

- How would you sum up your personal learning about helping, fixing and serving in the context of this course?

- How does your reflection inform your conception of Public Service?

- What questions emerged from writing this reflection?

- Responding to this final question should take about a paragraph. 


\section{APPENDIX H: Course Two Narrative Part Two Assignment Description}

\section{Personal Public Service Reflection \#2}

Please respond to the following prompts in this reflection:

-Please describe a time in your life in which you noticed yourself in fixing/ helping mode. (Max. 1 paragraph.)

- What was the context?

- What motivations were you bringing to the experience? (This is one of the harder questions; try to be honest in service of your own learning.)

- What do you think it was about the situation - the time in your life, the people around you, other factors - that led you into fixing/helping mode?

-Please describe a time in your life in which you noticed yourself in serving mode. Think about a time when you felt you were in alignment with your values around service, were able to "show up" in a way that felt good to you, and seemed to work well for those you were serving. (Max. 1 paragraph.)

- What was the context?

-What motivations were you bringing to the experience?

- What do you think it was about the situation - the time in your life, the people around you, other factors - that allowed you to be in serving mode?

-Please describe what you notice about the difference between the above experiences in terms of what allowed you to show up and serve. (About 2 paragraphs.)

- What two needs were met that allowed you to serve? (Refer to the Rosenberg if you would like some examples of needs or to understand how I'm using the term "needs" here.)

- How did you experience those needs being met when you were serving?

- How did the fact that the needs were met allow you to serve?

-Going forward in your life... (1 paragraph)

-What can you do (that you're not already doing) to meet these needs for yourself as you serve?

-What is one specific example of a context in which you serve, or want to serve, and the way you could meet one of these needs for yourself?

-What act of service might you be capable of if you were able to meet your needs? 


\section{APPENDIX I: Data Analysis Sample}

\section{Selected Notes from Analysis of Course One Narrative Part Two}

\section{STEP 1: INITIAL MEMO}

What I'm hoping for here with the assignment is to make it okay and important to work with disengagement.

What this really reminds me of is bringing the insight of the mental body to the emotional body and physical body. That mental insight frees a new emotional response, and makes room for new behavior. There's also a trust in the process involved here, because by trusting that this difficult experience had some teaching capacity, they are engaging with a world that is receptive to them, kind to them, and that they can handle.

There's very much the finding that the vision is really hard for them to access. So their vision is not really something that I can be building curricula off of at this stage. And so this is really suggesting the extent to which vision is something that needs to be earned and there's a maturity and process that needs to be there in order to access vision.

The other piece is becoming aware of how the concept of insight and clarity and free choice could be used here as language to refer to people's unconscious decision making based on past experience. The past experiences become resistance or an inclination not to engage. But by bringing mindfulness awareness compassion and presence, there's an opportunity for a different level of choice that is a more conscious aware purposeful choice. This feels very political and very clearly about about allowing us to be civically engaged and work toward political changes.

\section{STEP 2: IDENTIFY QUOTES THAT SEEM TO INFORM THE RESEARCH}

\section{QUESTION}

\section{$\underline{\text { Student Quotes and Paraphrases }}$}

Note: The below quotes are only a sample comprising about $25 \%$ of the quotations selected and sorted.

"Dear _ _ I urge you to never stop evolving, and never settle for less than you deserve. Be proud of your journey and learn from your mistakes. I hope this message guides you to find a place for forgiveness in your heart." 
a) Apologizes to past self, for instance of being called a liar and thief in all-white household by a close friend. "But most of what I'm sorry about is the way you felt disengaged for the whole rest of the year and how you felt extremely isolated from and hated [by] her, and how it made everyone think that about you even though you would have done anything for your friends."

b) Really astute empathy. Names to self "you sat there paralyzed in fear and angry mostly due to your body's fight or flight response...you really wanted to fight but just let it slide and played it off with a chuckle. Really it hurt so much more than that chuckle you gave off." Later that night it hit you_-"you felt this sickening feeling of being ashamed and embarrassed even though you did nothing wrong." The fact that she said it in front of everyone "made you feel so ashamed of yourself." Also names the feelings of confusion and agitation.

c) Clearly understands empathy process: "Now I'm going to have not really answers but what was causing those feelings and why you felt that way." Names needs for trust, clarity, integrity. Interprets this as disrespect for the parents who raised him.

(3)

a) "There are so many more times you have been disengaged because of mental illness, so this letter is for whenever you feel that way again. This will serve as a life long reminder that each disengagement is a learning experience and it's okay to feel the way you do, and this is a way to try and avoid disengagement again."

b) encouraging...coaxing a new way forward.] To address the tendency to disengage when people don't understand her depression. "Try and understand that the others person probably feels the same way when they are trying to understand how you feel. I think this [class activity] is the perfect example and can remind you to be empathetic to the person who is listening to you. It's okay if they don't understand, they don't know your view on it."

c) [Reframing to mobilize younger self] A take home is "learning from the conflict instead of 'winning or losing,' it can be used to understand a problem, and it can give us options for action."

a) "Your ability to contribute outward was infiltrated by one of the select few meant to support you. Their failure to meet your need for security, support and understanding, doesn't need to weight you down, but reaffirm your desire to move forward as a positive example down your own path." 
b) [Generalized positivity and encouragement. It still feels sincere and reflective of a determination not to get stuck in future]. "Because common ground wasn't found today, it doesn't mean it can't be in the future. Your willingness to truly understand and aid one another, is part of your process and growth as a leader in creating the very change you wish to see in our world."

a) "If you felt ashamed and insecure because she was judging your priorities in life it's okay to have those emotions. Through this experience it would make sense to feel a sense of detachment from the institution this person works for and I'm sure it was born from the moment she walked away from you."

b) "Maybe, one thing you can take from this situation is that you now know you deserve to be truly heard, now you know what that means, and what the opposite feels like."

\section{(6)}

[Sense of working through and getting an insight from the process. Sense that this insight creates engagement.] This is highlighted by addressing "Dear Disengaged _ " and signing “____ Engaged.” The insight is to address overwhelm with seeing his life as integrated.

a) Narrates the why and the process

b) 'Jane posed the question 'What got stuck?' as a result of this and I feel like the thing that got most stuck was the relationships. I have since created distance because I still feel...I admired you past self...because now I think I've lost the drive to push beyond anything surface level with them and our relationships have suffered as a result."

\section{(8)}

"When I continued the reading and came across the six inherent rights [in Lappe], I really questioned the way I used to think about myself in school [which is "not smart"]. Reading about the eco-mind has showed me that the process is not perfect and not easy but if you trust it and make an effort, the disengagement fades slowly and allows a person to grow." 
a) "You need to be brave enough to take the first step. Whether it's other people or your own inner voice telling you, "it's not worth it." When it's something like this, something that you feel is important, you need to tune out your detractors and act."

b) "You need to treat situations [friend discussion] like this as opportunities from which to grow and not tests that you either pass or fail."

c) [Point that sometimes students' reconciliation has clear political implications, like his realization that he wants to be less positional in conversations about political/social topics.]

d) Context of Rosenberg. "You have a tendency to go into conversations wanting to win, like you're on one team and the other person is your opponent. Instead of doing this you need to be the mediator of your own conversation. Look inward and ask yourself what do you need to be happy with this interaction and be honest with yourself...You're allowed to guess what the other person's needs might be and have them confirm this. This might be difficult but it will lead you to having conversations that can affect people."

a) Going from disengagement from overwhelm and taking Vaclev Havel chapter. Message that success is not ensured, but there is value in working toward "good." Uses Zinn and other hopefulness to get back hope. "I don't believe that you want to lay down and die or join the side of accepting emotional misery. I believe you're stronger than that and you have too much to offer to just voluntarily sit on the sidelines, watching the continuation of everything you believe is morally wrong."

b) "It was a power situation where the adults had the power and they knew I was a kid and didn't think I had what it took to overcome the situation.

c) [Insight with political implications. Note that this insight is interpersonal and is about individuals but has implications for social capital relationships built throughout life.]

d) Says focus on communicating with people who are listening to understand. "this is only a little trick I just learned: to pick your conversations wisely." It's okay to walk away from people who have no intent to understand.

e) [Pretty clear work with a very political quality: standing up for herself/leadership.] "I'm sharing this with you because I want to validate, yes, it is okay to publicly stand up to the adults that are belittling you right now. Even though it feels like it will not make a difference, it is important to still stand up to them because every little action can equate to a bigger change."

f) "Continue to be yourself and build people up to re-engage even though it is so challenging. This is the time to get more involved than ever even though you want to do the opposite."

\section{STEP 3: INTIAL THEMES}




\section{Initial Themes:}

- Self love (1)

- Encouragement to keep growing (3)

- Impatience. Telling self to get over it because things are better now. A combo of empathy and harshness (1)

- **Capacity to name feelings and needs (11)

- Some sense of an advanced version of this - analyzing what happened and why (3)

- Gathering up the past self and dusting them off. Let's get started. (4)

- Even if no LO 2 or 3, insight as useful (2).

- Stopping at empathy (2)

- Racism (1)

- Culture (2)

- Stigma (2)

- Power dynamic with adults and children (1)

\section{STEP 4: REFINE THEMES}

\section{Refined Themes:}

Students' capacity to utilize empathetic analysis for re-engagement toward a vision fell into three levels:

Level 1: Students demonstrated capacity to empathetically analyze an experience of disengagement. All students reached Level 1.

Level 2: Most students demonstrated ability to follow their empathetic analysis with relevant insight that seemed to lead toward re-engagement.

Level 3: A smaller group demonstrated the above two capacities as well as the ability to invoke a meaningful vision in order to re-engage in a specific and directed way.

\section{STEP 5: SORT QUOTATIONS BY THEME AND REVISE THEMES}

This step involved copying and pasting student quotations under the refined themes. I then assessed the accuracy of the themes.

\section{STEP 6: SECOND RESEARCH MEMO}

It seems I can organize people's contextualization essays, into what I think will be three or four categories of how deep they went with it. 
- The first level being they gave empathy to the younger self

- The second one being they gave empathy and some additional insight that helped them move forward

- The third one being that they really got that insight in there but they also engaged that younger self explicitly in service of the vision. In general the finding is really that they were not able to truly incite a younger self back into the present through a specific vision. It's more that they bring that younger self back into the present with with a generous pep talk and encouragement and care and kind of wanting that younger self to not have to be stuck and to realize essentially that what was past is no longer present.

Maybe one way of seeing it is that this class is a generalized engagement class. It displays all these ways of engaging despite the odds. It shows to some extent why it's important. I would like to add that reflection more explicitly to the class: What happens to a society without civic engagement? So the scale we're working on is quite generalized. It works with the generalized energy of engagement. It does not really work with the question of vision. It does not guide students through areas of interest. It does not give them an introduction to policy issues in their area of interest. The CBL project is meant to do some of that work. So this raises the question of what a college curricula would look like that really engages vision. Can this only happen at the thesis level? The MA level? 


\section{APPENDIX J: Guide Used for Rubric Development Source: Wald, et al. (2012)}

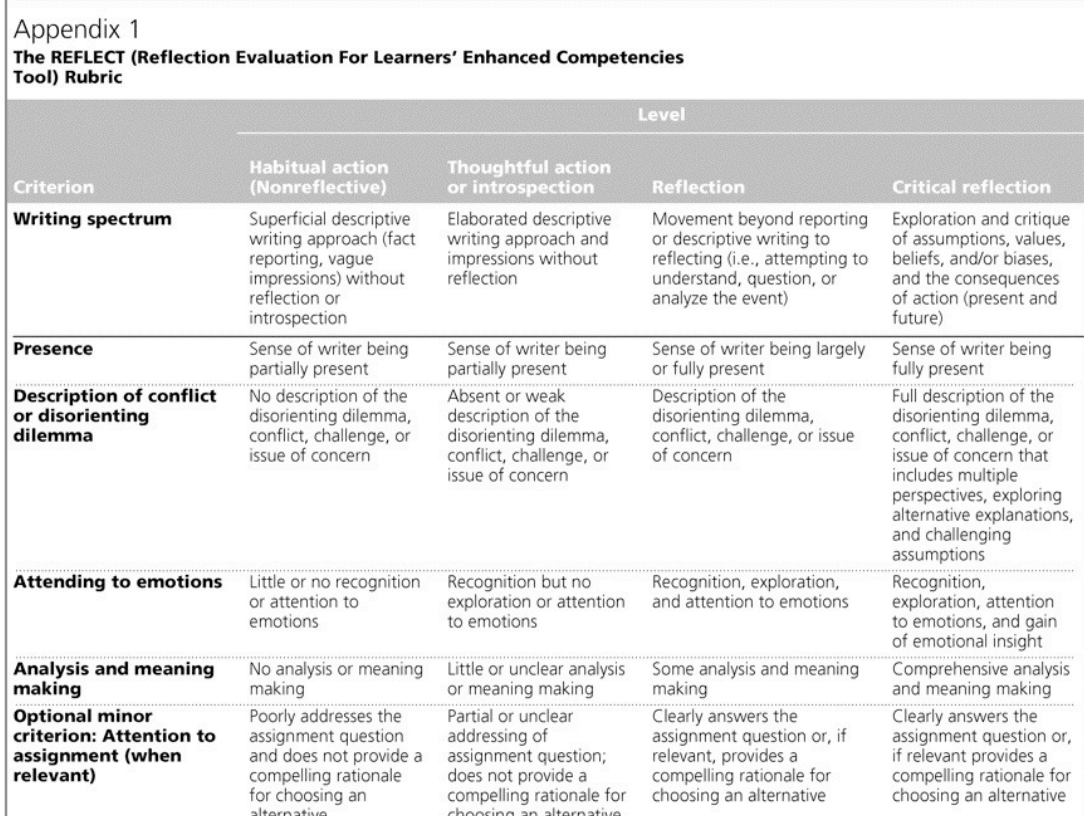

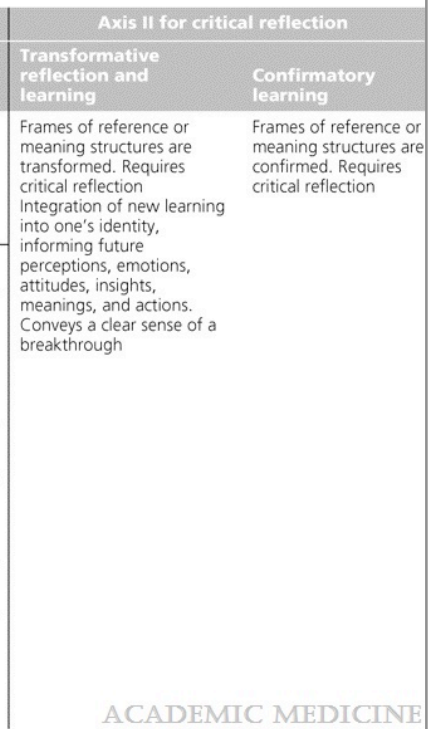

